\title{
Arabian Sea Mixed Layer Dynamics Experiment Data Report
}

\author{
by \\ Mark F. Baumgartner \\ Nancy J. Brink \\ William M. Ostrom \\ Richard P. Trask \\ Robert A. Weller \\ Upper Ocean Processes Group \\ Woods Hole Oceanographic Institution \\ Tommy D. Dickey \\ Ocean Physics Laboratory \\ University of California, Santa Barbara \\ John Marra \\ Lamont-Doherty Earth Observatory \\ Columbia University
}

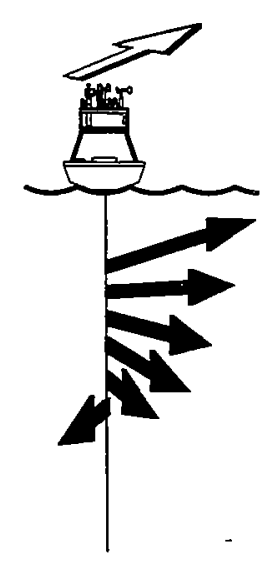




\title{
WHOI-97-08 \\ UOP Report 97-03
}

\section{Arabian Sea Mixed Layer Dynamics Experiment Data Report}

\author{
by \\ Mark F. Baumgartner \\ Nancy J. Brink \\ William M. Ostrom \\ Richard P. Trask \\ Robert A. Weller \\ Upper Ocean Processes Group \\ Woods Hole Oceanographic Institution \\ Tommy D. Dickey \\ Ocean Physics Laboratory \\ University of California, Santa Barbara \\ John Marra \\ Lamont-Doherty Earth Observatory \\ Columbia University

\section{Upper Ocean Processes Group} \\ Woods Hole Oceanographic Institution \\ Woods Hole, Massachusetts 02543-1541
}

July 1997

\section{Technical Report}

Funding provided by the Office of Naval Research under

Contract No. N00014-94-1-0161.

Reproduction in whole or in part is permitted for any purpose of the United States

Government. This report should be cited as:

Woods Hole Oceanog. Inst. Tech. Rept., WHOI-97-08

Approved for publication; distribution unlimited.

\section{Approved for Distribution:}

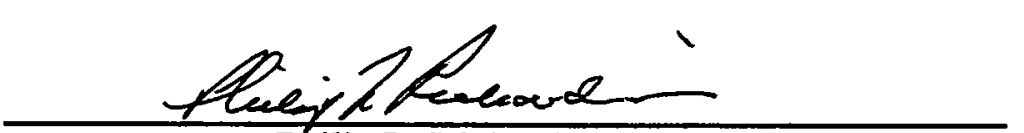

Philip L. Richardson, Chair

Department of Physical Oceanography 


\begin{abstract}
The Arabian Sea is characterized by strong, large-scale atmospheric forcing during the summer (southwest) and winter (northeast) monsoons. To investigate air-sea interactions related to this unique surface forcing, a moored array was deployed from 15 October 1994 to 19 October 1995 just south of a region that experiences the climatological maximum winds during the summer monsoon. The array consisted of two Scripps Institution of Oceanography surface toroid buoys, two University of Washington subsurface moorings and a surface $3 \mathrm{~m}$ discus buoy deployed by the Woods Hole Oceanographic Institution (WHOI). The WHOI buoy carried redundant meteorological packages to measure wind speed and direction, air temperature, relative humidity, barometric pressure, incoming short- and long-wave radiation and precipitation. Oceanographic instrumentation was deployed on the WHOI buoy's bridle and mooring line to collect time series of temperature, salinity and velocity at various depths. Four multi-variable moored systems (MVMS) were also deployed along the mooring line by the Lamont-Doherty Earth Observatory and the University of California at Santa Barbara to record both bio-optical and physical parameters. This report describes the instrumentation deployed on the WHOI buoy and the processing and editing of the returned data. The data are then summarized in graphical and tabular formats.
\end{abstract}




\section{Table of Contents}

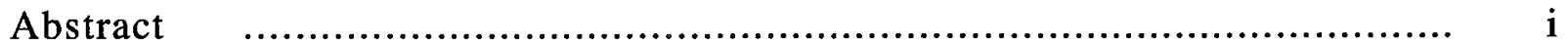

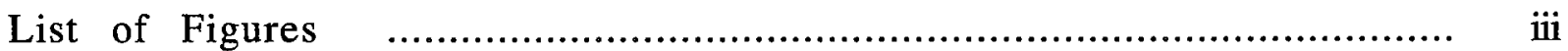

List of Tables ......................................................................... vii

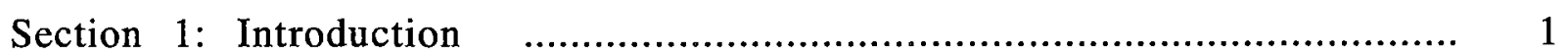

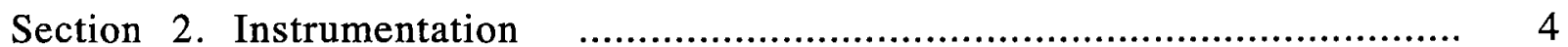

Section 3: Data Processing ................................................................. 14

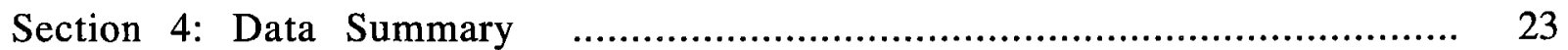

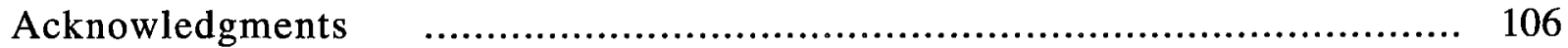

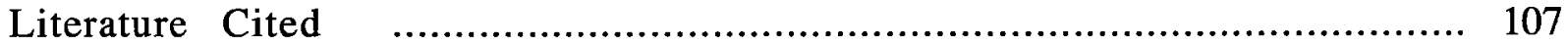

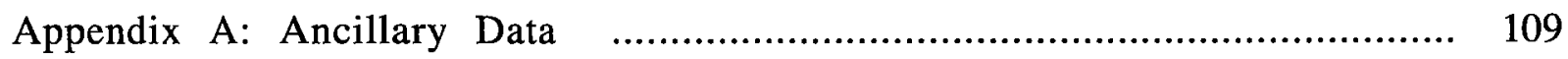

Appendix B: Instrument Serial Numbers …............................................... 155

Appendix C: VMCM Record Format …............................................... 157 


\section{List of Figures}

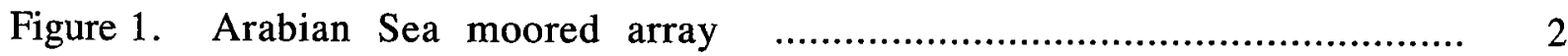

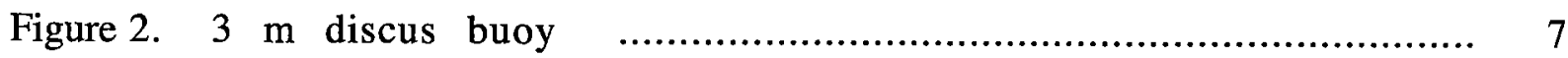

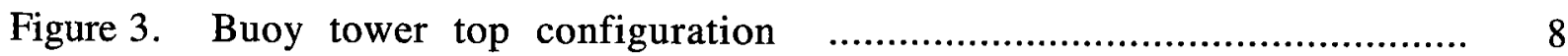

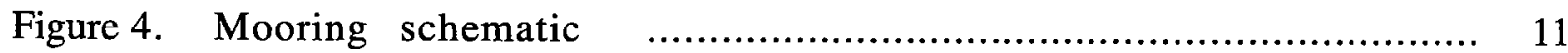

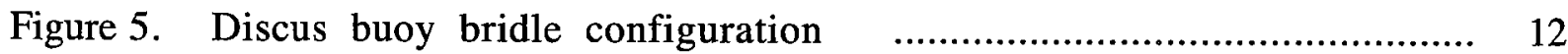

Figure 6. Booby signal in long-wave radiation measurements .......................... 21

Figure 7. Hourly time series of meteorological observations $\quad$............................. 38

Figure 8. Time series of meteorological observations for October 1994 ................. 39

Figure 9. Time series of meteorological observations for November $1994 \quad \ldots \ldots \ldots \ldots . . . . \quad 40$

Figure 10. Time series of meteorological observations for December 1994 ............... 41

Figure 11. Time series of meteorological observations for January $1995 \quad \ldots . . . \ldots \ldots \ldots . . . .4 \quad 42$

Figure 12. Time series of meteorological observations for February 1995 ................ 43

Figure 13. Time series of meteorological observations for March 1995 .................... 44

Figure 14. Time series of meteorological observations for April 1995 .................... 45

Figure 15. Time series of meteorological observations for May 1995 ..................... 46

Figure 16. Time series of meteorological observations for June 1995 ...................... 47

Figure 17. Time series of meteorological observations for July $1995 \quad$........................ 48

Figure 18. Time series of meteorological observations for August 1995 .................. 49

Figure 19. Time series of meteorological observations for September 1995 .............. 50

Figure 20. Time series of meteorological observations for October $1995 \quad \ldots . . . \ldots \ldots \ldots . . . . . \quad 51$

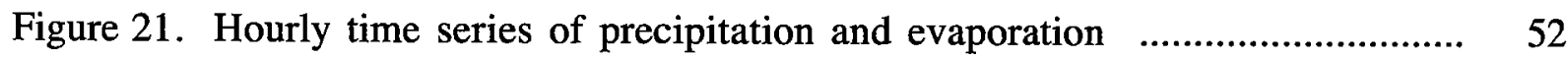

Figure 22. Hourly time series of estimated heat and momentum fluxes ................... 53

Figure 23. Time series of heat and momentum fluxes for October 1994 .................. 54

Figure 24. Time series of heat and momentum fluxes for November 1994 ............... 55

Figure 25. Time series of heat and momentum fluxes for December 1994 ................ $\quad 56$

Figure 26. Time series of heat and momentum fluxes for January $1995 \quad \ldots . . . \ldots . . . . . . . . . . \quad 57$

Figure 27. Time series of heat and momentum fluxes for February $1995 \quad$................. 58

Figure 28. Time series of heat and momentum fluxes for March 1995 ..................... 59

Figure 29. Time series of heat and momentum fluxes for April 1995 ........................ 60

Figure 30. Time series of heat and momentum fluxes for May $1995 \quad \ldots \ldots \ldots \ldots \ldots \ldots \ldots . . . . . . . . . . .61$

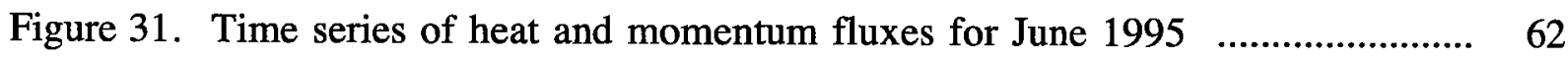

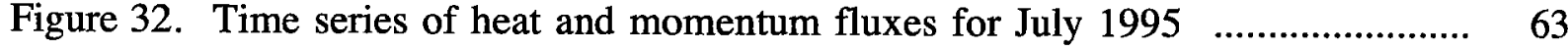

Figure 33. Time series of heat and momentum fluxes for August $1995 \quad$...................... 64 
Figure 34. Time series of heat and momentum fluxes for September $1995 \quad \ldots \ldots \ldots \ldots \ldots \ldots . . . .65$

Figure 35. Time series of heat and momentum fluxes for October $1995 \quad \ldots \ldots \ldots \ldots . . . . . . . . . .66$

Figure 36. Contour plot of temperature and mixed layer depth ............................. 67

Figure 37. Contour plot of temperature and mixed layer depth for October $1994 \ldots . . . . . . .68$

Figure 38. Contour plot of temperature and mixed layer depth for November 1994 ...... 69

Figure 39. Contour plot of temperature and mixed layer depth for December 1994 ....... 70

Figure 40. Contour plot of temperature and mixed layer depth for January 1995 .......... 71

Figure 41. Contour plot of temperature and mixed layer depth for February $1995 \quad$........ 72

Figure 42. Contour plot of temperature and mixed layer depth for March 1995 ........... 73

Figure 43. Contour plot of temperature and mixed layer depth for April 1995 ............. 74

Figure 44. Contour plot of temperature and mixed layer depth for May 1995 .............. 75

Figure 45. Contour plot of temperature and mixed layer depth for June 1995 ............. 76

Figure 46. Contour plot of temperature and mixed layer depth for July 1995 ............. 77

Figure 47. Contour plot of temperature and mixed layer depth for August 1995 .......... 78

Figure 48. Contour plot of temperature and mixed layer depth for September 1995 ...... 79

Figure 49. Contour plot of temperature and mixed layer depth for October $1995 \quad \ldots \ldots . . . . .80$

Figure 50. VMCM and MVMS velocity stick plots from WHOI mooring .................. 81

Figure 51. VMCM and MVMS velocity stick plots from UW South mooring ............ 82

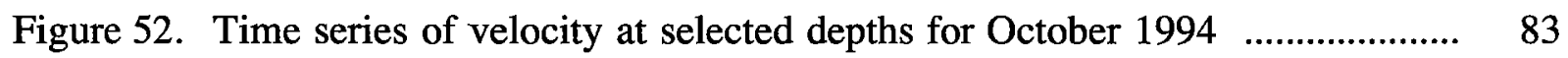

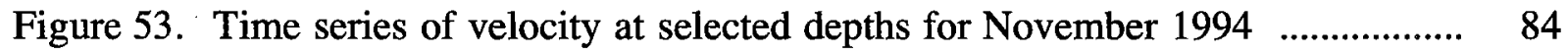

Figure 54. Time series of velocity at selected depths for December $1994 \ldots \ldots . . . . . . . . . . . . \quad 85$

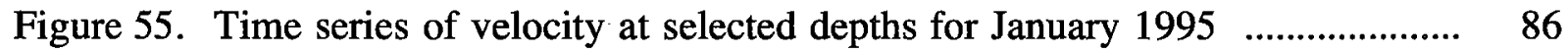

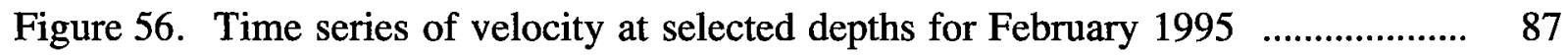

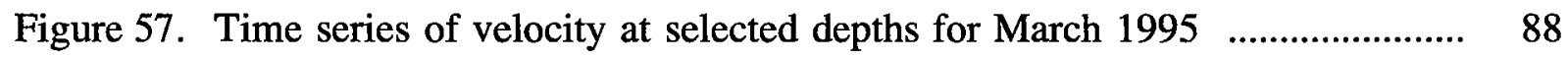

Figure 58. Time series of velocity at selected depths for April 1995 ........................ 89

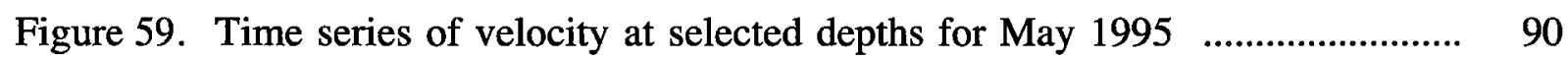

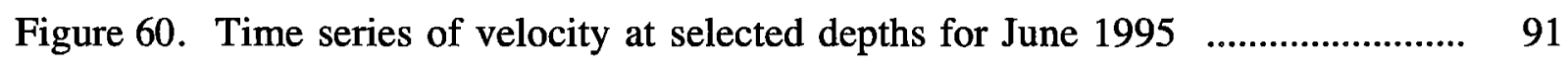

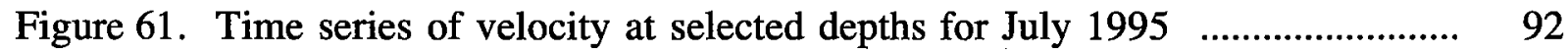

Figure 62. Time series of velocity at selected depths for August $1995 \quad \ldots \ldots \ldots \ldots . . . . . . . . . . . . \quad 93$

Figure 63. Time series of velocity at selected depths for September $1995 \quad \ldots . . . . . . . . . . . . . . . \quad 94$

Figure 64. Time series of velocity at selected depths for October 1995 ..................... 95

Figure 65. Progressive vectors from VMCM and MVMS current meters .................. 96

Figure 66. Monthly progressive vectors …................................................. 97

Figure 67. Autospectra of meteorological parameters _................................... 100

Figure 68. Autospectra of heat and momentum fluxes ..................................... 101

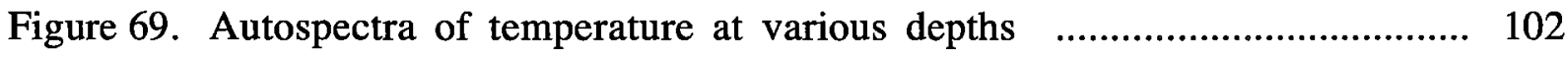


Figure 70. Rotary autospectra of velocity at various depths 104

Figure A1. Shipboard meteorological observations during cruise TN040 $\quad$.................. 112 Figure A2. Shipboard meteorological observations during cruise TN042 $\ldots \ldots \ldots \ldots \ldots \ldots \ldots . . . . .113$ Figure A3. Shipboard meteorological observations during cruise TN044 f................ 114 Figure A4. Shipboard meteorological observations during cruise TN046 .................. 115 Figure A5. Shipboard meteorological observations during cruise TN048 f................. 116 Figure A6. Shipboard meteorological observations during cruise TN051 .................. 117 Figure A7. Shipboard meteorological observations during cruise TN052 ................. 118

Figure A8. Estimated heat and momentum fluxes during cruise TN040 ................... 119

Figure A9. Estimated heat and momentum fluxes during cruise TN042 …............... 120

Figure A10.Estimated heat and momentum fluxes during cruise TN044 ................... 121

Figure A11.Estimated heat and momentum fluxes during cruise TN046 ................... 122

Figure A12.Estimated heat and momentum fluxes during cruise TN048 ................... 123

Figure A13.Estimated heat and momentum fluxes during cruise TN051 .................... 124

Figure A14.Estimated heat and momentum fluxes during cruise TN052 …................ 125

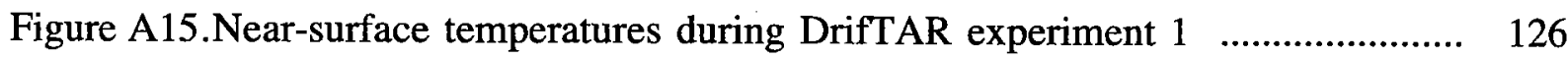

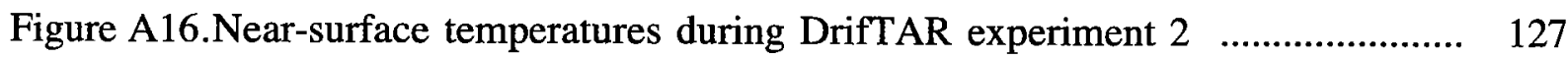

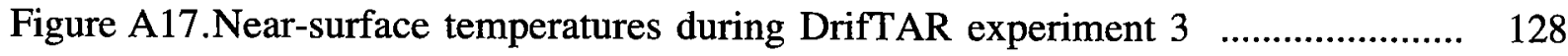

Figure A18.ECMWF vs. VAWR wind speed comparison …............................. 129

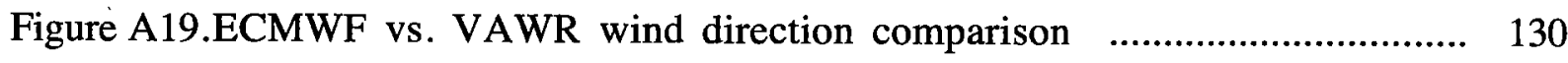

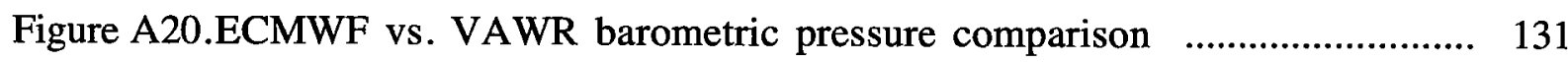

Figure A21.ECMWF vs. VAWR air temperature comparison …........................... 132

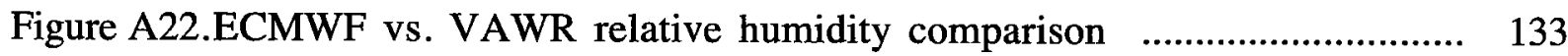

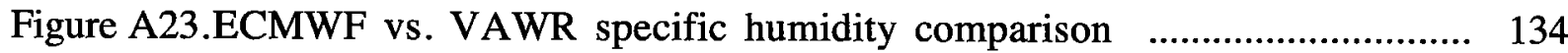

Figure A24.ECMWF vs. VAWR sea surface temperature comparison $\ldots . . . \ldots \ldots \ldots . . . . . . . . . . . .135$

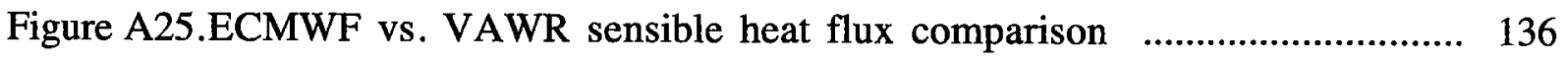

Figure A26.ECMWF vs. VAWR latent heat flux comparison $\ldots . . . \ldots \ldots \ldots \ldots \ldots \ldots \ldots \ldots . . . . . . . . . . . . . .137$

Figure A27.ECMWF vs. VAWR net short-wave radiation comparison $\ldots . . . . . . . . . . . . . . . . . .138$

Figure A28.ECMWF vs. VAWR net long-wave radiation comparison $\quad$....................... 139

Figure A29.ECMWF vs. VAWR net heat flux comparison ................................ 140

Figure A30.ECMWF vs. VAWR wind stress magnitude comparison ........................ 141

Figure A31.NCEP vs VAWR wind speed comparison …................................ 142

Figure A32.NCEP vs VAWR wind direction comparison …............................. 143

Figure A33.NCEP vs VAWR barometric pressure comparison ............................ 144

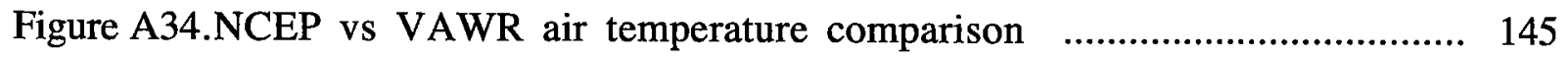


Figure A35.NCEP vs VAWR relative humidity comparison $\ldots . . . \ldots \ldots \ldots \ldots \ldots \ldots \ldots \ldots \ldots . . . . . . . . . . . . . .146$

Figure A36.NCEP vs VAWR specific humidity comparison ............................... 147

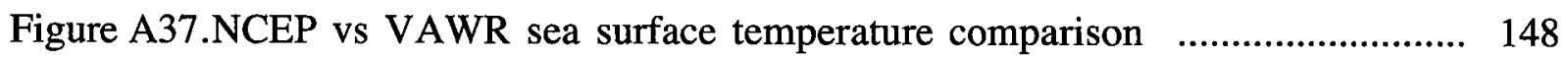

Figure A38.NCEP vs VAWR sensible heat flux comparison ............................... 149

Figure A39.NCEP vs VAWR latent heat flux comparison …................................ 150

Figure A40.NCEP vs VAWR net short-wave radiation comparison $\quad$......................... 151

Figure A41.NCEP vs VAWR net long-wave radiation comparison $\quad$.......................... 152

Figure A42.NCEP vs VAWR net heat flux comparison …................................. 153

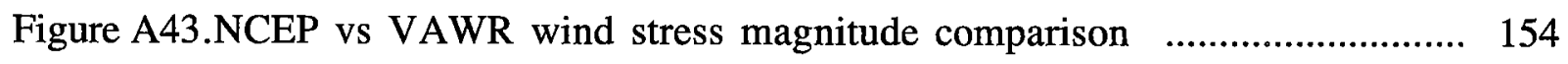




\section{List of Tables}

Table 1. Mooring deployment and recovery dates (UTC) and anchor positions .......... 1

Table 2. Sensors heights (in meters) above the mean water line ............................ 4

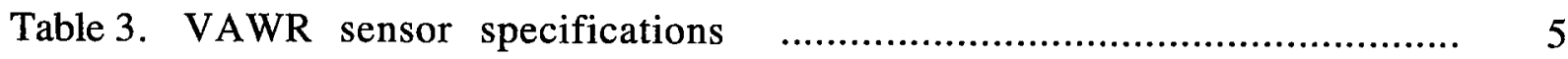

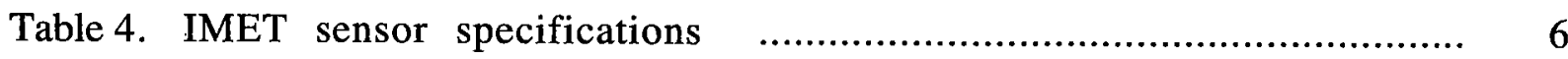

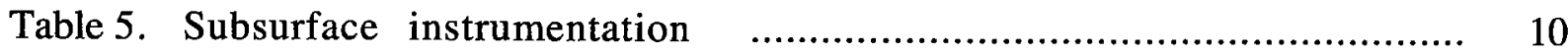

Table 6. WHOI subsurface instrumentation deployed on the UW moorings $\quad . . . . . . . . . . . . . .13$

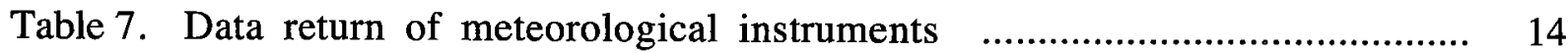

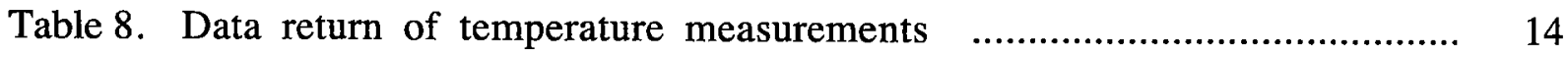

Table 9. Data return of temperature measurements on UW moorings ....................... 15

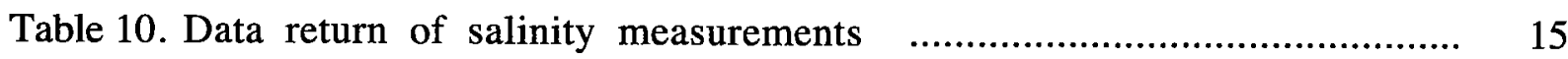

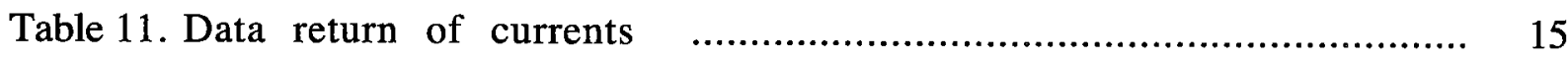

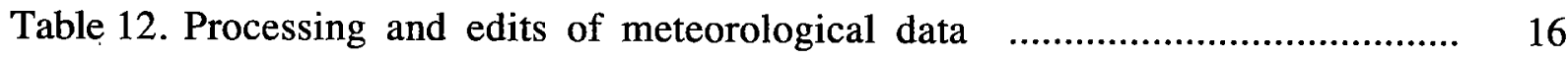

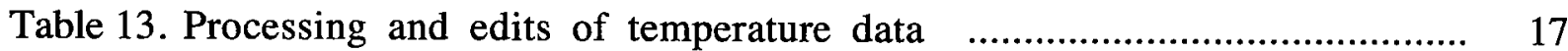

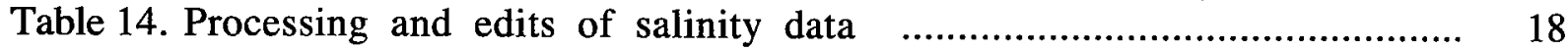

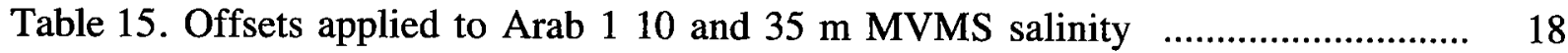

Table 16. Constants for $10 \mathrm{~m}$ MVMS time dependent salinity drift correction $\quad$.............. 18

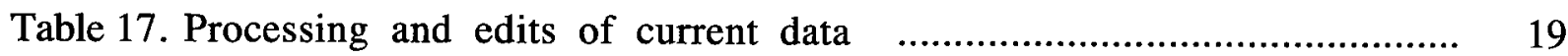

Table 18. Parameters used in bulk flux algorithm ...................................... 22

Table 19. Statistics of observables and fluxes for the entire deployment $\quad . . . . . . . . . . . . . . . . . .24$

Table 20. Statistics of observables and fluxes for October 1994 .............................. 25

Table 21. Statistics of observables and fluxes for November 1994 ......................... 26

Table 22. Statistics of observables and fluxes for December 1994 ............................ 27

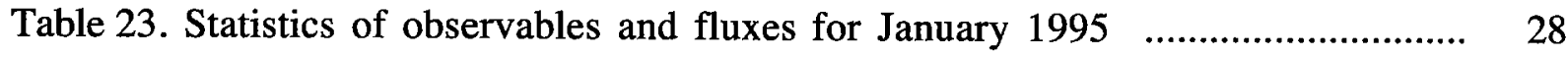

Table 24. Statistics of observables and fluxes for February $1995 \quad$........................... 29

Table 25. Statistics of observables and fluxes for March $1995 \quad$............................. 30

Table 26. Statistics of observables and fluxes for April 1995 ............................... 31

Table 27. Statistics of observables and fluxes for May 1995 ............................... 32

Table 28. Statistics of observables and fluxes for June 1995 .............................. 33

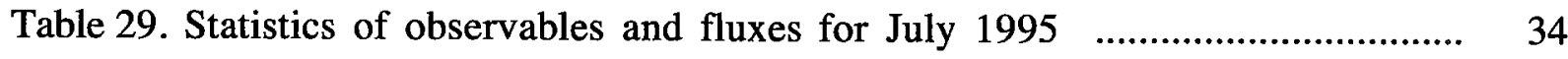

Table 30. Statistics of observables and fluxes for August $1995 \quad$............................. 35

Table 31. Statistics of observables and fluxes for September 1995 ........................ 36

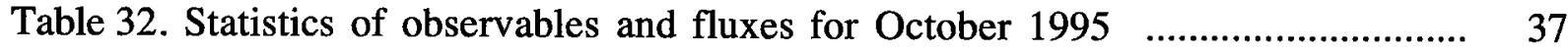


Table A1. Statistics of differences between ECMWF model and buoy observations ....... 111

Table A2. Statistics of differences between NCEP model and buoy observations .......... 111

Table B1. Serial numbers of meteorological instrumentation ….............................. 155

Table B2. Serial numbers of WHOI instrumentation deployed on UW moorings ........... 155

Table B3. Serial numbers of subsurface instrumentation ….................................. 156 


\section{Section 1: Introduction}

Meteorological forcing in the Arabian Sea is characterized by an intense atmospheric circulation during the summer or southwest monsoon known as the Findlater Jet and persistent, moderate winds during the winter or northeast monsoon. These conditions are rather unique when compared to other basins at similar latitudes since the wind forcing is much larger during the summer than in the winter. The annual cycle of sea surface temperatures (SST) in the Arabian Sea is also unique; the summer SST is nearly as low as the winter SST. Unfortunately, few in situ meteorological and oceanographic measurements have been collected in this region. To better understand the air-sea interactions in this region, a moored array was deployed for one year just south of the climatological axis of the Findlater Jet.

The array consisted of five moorings: a Woods Hole Oceanographic Institution (WHOI) surface mooring, two Scripps Institution of Oceanography (SIO) surface moorings and two University of Washington (UW) subsurface moorings (Figure 1). At all of the mooring sites except for the UW northeast site, the one year time series of meteorological and/or oceanographic measurements were recorded in two consecutive six month deployments. All mooring work was conducted from the R/V Thomas Thompson, beginning with the initial deployment in mid-October 1994 during cruise 40. The first set of moorings were recovered and the second set deployed in mid-April 1995 during cruise 46. The final recovery occurred in mid-October 1995 during cruise 52. Deployment and recovery times and mooring sites are presented in Table 1.

Table 1. Mooring deployment and recovery dates (UTC) and anchor positions.

\begin{tabular}{|c|c|c|c|}
\hline Mooring & Deployment Date/Time & Recovery Date/Time & Anchor Position \\
\hline \multicolumn{4}{|l|}{ Arab 1 } \\
\hline WHOI Central & 15 Oct 19941048 & 20 Apr 19950105 & $15^{\circ} 30.04^{\prime} \mathrm{N}, 61^{\circ} 29.99^{\prime} \mathrm{E}$ \\
\hline SIO Northwest & 17 Oct $1994 \quad 0723$ & 16.Apr 19951055 & $15^{\circ} 43.53^{\prime} \mathrm{N}, 61^{\circ} 15.94^{\prime} \mathrm{E}$ \\
\hline SIO Southwest & 18 Oct 19940649 & 23 Apr 19950652 & $15^{\circ} 16.53^{\prime} \mathrm{N}, 61^{\circ} 16.11^{\prime} \mathrm{E}$ \\
\hline UW Northeast & 23 Oct 19941000 & & $15^{\circ} 43.90^{\prime} \mathrm{N}, 61^{\circ} 44.53^{\prime} \mathrm{E}$ \\
\hline UW Southeast & 19 Oct 1994 morning & 18 Apr 19950150 & $15^{\circ} 16.37^{\prime} \mathrm{N}, 61^{\circ} 44.07^{\prime} \mathrm{E}$ \\
\hline \multicolumn{4}{|l|}{$\underline{\operatorname{Arab} 2}$} \\
\hline WHOI Central & 22 Apr 19950939 & 10 Oct 19951000 & $15^{\circ} 30.07^{\prime} \mathrm{N}, 61^{\circ} 30.05^{\prime} \mathrm{E}$ \\
\hline SIO Northwest & 17 Apr 19950715 & 19 Oct 19950601 & $15^{\circ} 43.39^{\prime} \mathrm{N}, 61^{\circ} 15.86^{\prime} \mathrm{E}$ \\
\hline SIO Southwest & 24 Apr 19950716 & 18 Oct $1995 \quad 0712$ & $15^{\circ} 16.52^{\prime} \mathrm{N}, 61^{\circ} 16.12^{\prime} \mathrm{E}$ \\
\hline UW Northeast & & 16 Oct 19950210 & $15^{\circ} 43.90^{\prime} \mathrm{N}, 61^{\circ} 44.53^{\prime} \mathrm{E}$ \\
\hline UW Southeast & 25 Apr 19950650 & 17 Oct 19951000 & $15^{\circ} 16.11^{\prime} \mathrm{N}, 61^{\circ} 43.82^{\prime} \mathrm{E}$ \\
\hline
\end{tabular}


The two SIO toroid buoys in the northwest and southwest corners of the array each supported redundant meteorological packages that measured wind speed and direction, air temperature, barometric pressure and incoming short-wave radiation, an acoustic doppler current profiler (ADCP) and ten subsurface temperature recorders. The UW subsurface moorings each carried a profiling current meter (PCM) and two temperature recorders. The southeastern UW mooring also carried five deep, vector measuring current meters (VMCM). The WHOI $3 \mathrm{~m}$ discus buoy supported two complete suites of meteorological instrumentation and a single stand-alone module capable of measuring all of the bulk parameters required for estimating heat, freshwater and momentum fluxes at the sea surface. The buoy and the mooring line also carried subsurface instrumentation to measure both physical and bio-optical properties.

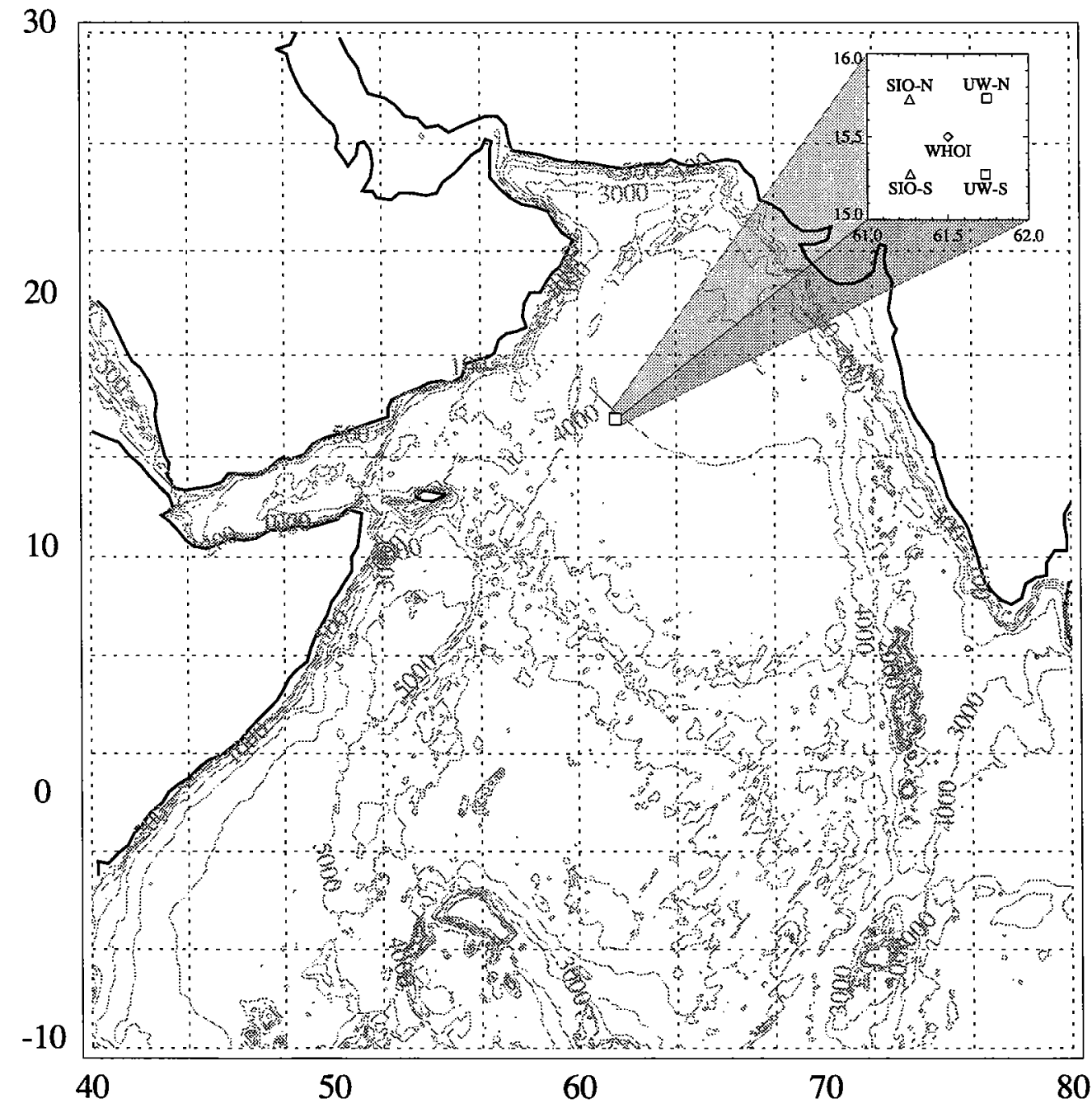

Figure 1. Arabian Sea moored array. Depth contours are in meters. 
This report documents the meteorological and oceanographic data returned from the central WHOI mooring. Section 2 describes the instrumentation deployed at the central mooring site, Section 3 briefly describes the post-recovery data processing and Section 4 provides a tabular and graphical summary of the data. 


\section{Section 2: Instrumentation}

\section{Meteorological}

Two meteorological packages, the Vector Averaging Wind Recorder (VAWR) and the Improved Meteorological (IMET) system, were deployed on the $3 \mathrm{~m}$ diameter discus buoy. Instrument heights above the mean water line for each meteorological system are provided in Table 2. The VAWR (Weller et al., 1990) logged measurements of air temperature, relative humidity, barometric pressure, wind speed and direction, short-wave and long-wave radiation and sea temperature every 7.5 minutes (Table 3). The IMET system (Hosom et al., 1995) logged the same parameters as the VAWR as well as precipitation and aspirated temperature every minute (Table 4). The IMET relative humidity module also contained a collocated air temperature sensor. In addition to the meteorological packages, a stand-alone, internally logging, humidity/temperature instrument was also deployed (Way, 1996). This module contained collocated relative humidity and temperature sensors which were sampled every 3.75 minutes. Further details about the meteorological instrumentation can be found in Trask et al. (1995a), Trask et al. (1995b) and Ostrom et al. (1996).

Table 2. Sensors heights (in meters) above the mean water line.

\begin{tabular}{lcccccc}
\hline & \multicolumn{2}{c}{ VAWR } & \multicolumn{2}{c}{ IMET } & \multicolumn{2}{c}{ Stand-alone } \\
Parameter & Arab 1 & Arab 2 & Arab 1 & Arab 2 & Arab 1 & Arab 2 \\
\hline Air temperature & 2.68 & 2.70 & 2.74 & 2.76 & 2.98 & 2.98 \\
Relative humidity & 2.69 & 2.72 & 2.74 & 2.79 & 2.98 & 2.98 \\
Barometric pressure & 2.76 & 2.76 & 2.77 & 2.86 & & \\
Wind speed & 3.36 & 3.34 & 3.16 & 3.25 & \\
Wind direction & 3.07 & 3.07 & 3.16 & 3.25 & \\
Short-wave radiation & 3.42 & 3.41 & 3.42 & 3.41 & \\
Long-wave radiation & 3.42 & 3.41 & 3.42 & 3.42 & & \\
Sea temperature & -0.92 & -0.92 & -0.89 & -0.89 & & \\
Aspirated air temperature & & & 2.20 & 2.19 & \\
Precipitation & & & 3.14 & 3.12 & \\
\hline
\end{tabular}

The instrumented buoy is shown in Figure 2 and the tower top layout is provided in Figure 3. The tower was designed to eliminate shading for some instruments while maximizing air flow for others. The short- and long-wave sensors were placed above all other sensors so that they were afforded an unobstructed view of the sky. 
Table 3. VAWR sensor specifications.

\begin{tabular}{|c|c|c|c|}
\hline Parameter & Sensor Type & Nominal Accuracy & Sampling \\
\hline Air temperature & $\begin{array}{l}\text { Thermistor } \\
\text { Yellow Springs } \\
\# 44034 \\
5 \mathrm{~K} @ 25^{\circ} \mathrm{C}\end{array}$ & $\begin{array}{l} \pm 0.2^{\circ} \mathrm{C} \text { when } \\
\text { wind }>5 \mathrm{~ms}^{-1}\end{array}$ & $1.875 \mathrm{~min}$ average $^{\mathrm{a}}$ \\
\hline Relative humidity & $\begin{array}{l}\text { Variable Dielectric Conductor } \\
\text { Vaisala Humicap } \\
\text { 0062HM }\end{array}$ & $\pm 2 \% \mathrm{RH}$ & $\begin{array}{c}3.515 \mathrm{sec} \text { burst } \\
\text { sample }^{b}\end{array}$ \\
\hline Barometric pressure & $\begin{array}{l}\text { Quartz crystal Digiquartz } \\
\text { Paroscientific } \\
\text { Model 215, } 216\end{array}$ & $\begin{array}{l} \pm 0.2 \mathrm{mbar} \text { when } \\
\text { wind }<20 \mathrm{~ms}^{-1}\end{array}$ & $\begin{array}{c}2.636 \mathrm{sec} \text { burst } \\
\text { sample }^{\mathrm{b}}\end{array}$ \\
\hline Wind speed & $\begin{array}{l}3 \text { cup anemometer } \\
\text { R.M. Young }\end{array}$ & $\begin{array}{c} \pm 2 \% \text { above } \\
0.7 \mathrm{~ms}^{-1}\end{array}$ & $\begin{array}{l}7.5 \text { min vector } \\
\text { averaged }^{c}\end{array}$ \\
\hline Wind direction & $\begin{array}{l}\text { Integral vane w/ vane follower } \\
\text { WHOI / EG\&G }\end{array}$ & $\pm 5.6^{\circ}$ & $\begin{array}{l}7.5 \text { min vector } \\
\text { averaged }\end{array}$ \\
\hline Short-wave radiation & $\begin{array}{l}\text { Pyranometer } \\
\text { Eppley 8-48 }\end{array}$ & $\pm 3 \%$ of value & $7.5 \mathrm{~min}$ average \\
\hline $\begin{array}{c}\text { Long-wave radiation } \\
\text { Thermopile }\end{array}$ & $\begin{array}{l}\text { Pyrgeometer } \\
\text { Eppley PIR }\end{array}$ & $\pm 10 \%$ & $7.5 \mathrm{~min}$ average \\
\hline Body Temperature & $\begin{array}{l}\text { Thermistor } \\
10 \mathrm{~K} @ 25^{\circ} \mathrm{C}\end{array}$ & & $1.875 \mathrm{~min}$ average $^{\mathrm{d}}$ \\
\hline Dome Temperature & $\begin{array}{l}\text { Thermistor } \\
10 \mathrm{~K} @ 25^{\circ} \mathrm{C}\end{array}$ & & $1.875 \mathrm{~min}$ average ${ }^{\mathrm{e}}$ \\
\hline Sea temperature & $\begin{array}{l}\text { Thermistor } \\
\text { Thermometrics } \\
4 \mathrm{~K} @ 25^{\circ} \mathrm{C}\end{array}$ & $\pm 0.005^{\circ} \mathrm{C}$ & $1.875 \mathrm{~min}$ average $^{\mathrm{f}}$ \\
\hline
\end{tabular}

a Air temperature is measured during the second quarter of the sampling interval for one quarter of the record time.

b Relative humidity and barometric pressure are burst samples taken in the middle of the sampling interval.

c Overestimation of wind speed by about $5 \%$ is characteristic of cup anemometers.

d Long-wave radiation body temperature is measured during the third quarter of the sampling interval for one quarter of the record time.

e Long-wave radiation dome temperature is measured during the fourth quarter of the sampling interval for one quarter of the record time.

f Sea temperature is measured during the first quarter of the sampling interval for one quarter of the record time. 
Table 4. IMET sensor specifications.

\begin{tabular}{|c|c|c|c|}
\hline Parameter & Sensor Type & Nominal Accuracy & Sampling \\
\hline Air temperature & $\begin{array}{l}\text { Platinum Resistance } \\
\text { Thermometer }\end{array}$ & $\pm 0.25^{\circ} \mathrm{C}$ & $\begin{array}{l}\text { Burst sample } \\
\text { every } 1 \mathrm{~min}\end{array}$ \\
\hline Relative humidity & Rotronic MP-100F & $\pm 3 \% \mathrm{RH}$ & $\begin{array}{l}\text { Burst sample } \\
\text { every } 1 \mathrm{~min}\end{array}$ \\
\hline Barometric pressure & $\begin{array}{l}\text { Quartz crystal } \\
\text { AIR DB-1A }\end{array}$ & $\pm 0.5 \mathrm{mbar}$ & $\begin{array}{l}\text { Burst sample } \\
\text { every } 1 \mathrm{~min}\end{array}$ \\
\hline Wind speed & $\begin{array}{l}\text { Wind monitor } \\
\text { R.M. Young } \\
\text { Model } 5103\end{array}$ & $\pm 2 \%$ & 1 min average $e^{a, b}$ \\
\hline Wind direction & $\begin{array}{l}\text { Wind monitor } \\
\text { R.M. Young } \\
\text { Model } 5103\end{array}$ & $\pm 1.5^{\circ}$ & 1 min average $^{\mathrm{a}}$ \\
\hline Short-wave radiation & $\begin{array}{l}\text { Temperature compensated } \\
\text { Thermopile Eppley PSP }\end{array}$ & $\pm 3 \%$ of value & 1 min average $e^{c}$ \\
\hline Long-wave radiation & $\begin{array}{l}\text { Pyrgeometer } \\
\text { Eppley PIR }\end{array}$ & $\pm 10 \%$ & $\begin{array}{l}\text { Burst sample } \\
\text { every } 1 \text { min }\end{array}$ \\
\hline Sea temperature & $\begin{array}{l}\text { Platinum Resistance } \\
\text { Thermometer }\end{array}$ & $\pm 0.005^{\circ} \mathrm{C}$ & $\begin{array}{l}\text { Burst sample } \\
\text { every } 1 \text { min }\end{array}$ \\
\hline Precipitation & $\begin{array}{l}\text { Self-siphoning rain gauge } \\
\text { R.M. Young } \\
\text { Model } 50201\end{array}$ & $\pm 10 \%$ & $\begin{array}{l}\text { Burst sample } \\
\text { every } 1 \mathrm{~min}\end{array}$ \\
\hline Aspirated air temperature & $\begin{array}{l}\text { Platinum Resistance } \\
\text { Thermometer with R. M. } \\
\text { Young Aspirated Shield } \\
\text { Model } 43408\end{array}$ & $\begin{array}{c} \pm 0.2^{\circ} \mathrm{C} \text { when } \\
\text { short-wave }<1080 \\
\quad W \mathrm{~m}^{-2}\end{array}$ & $\begin{array}{l}\text { Burst sample } \\
\text { every } 1 \mathrm{~min}\end{array}$ \\
\hline \multicolumn{4}{|c|}{$\begin{array}{l}\text { The vane on the wind module is sampled at one second intervals and averaged over } 15 \text { seconds. } \\
\text { The compass is sampled every } 15 \text { seconds and the wind speed is averaged every } 15 \text { seconds. East } \\
\text { and north components are computed every } 15 \text { seconds. Once a minute the logger stores average } \\
\text { east and north components computed from the most recent four } 15 \text { second averages. } \\
\text { b Underestimation of wind speed by about } 3 \% \text { is characteristic of propeller anemometers. } \\
\text { c Short-wave radiation is sampled every } 10 \text { seconds and the average of the six most recent samples is } \\
\text { logged. }\end{array}$} \\
\hline
\end{tabular}




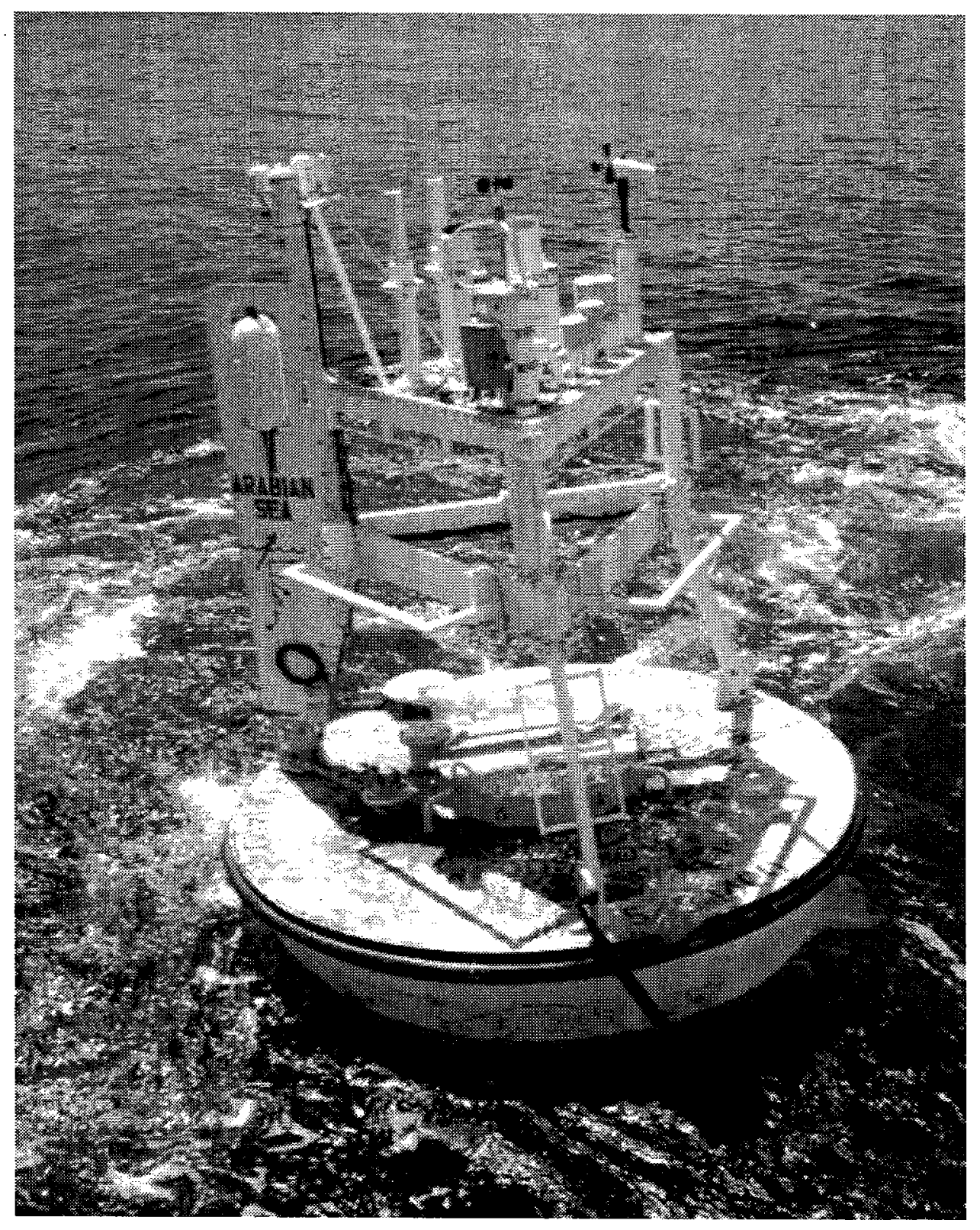

Figure 2. Arabian Sea 3m discus buoy. 

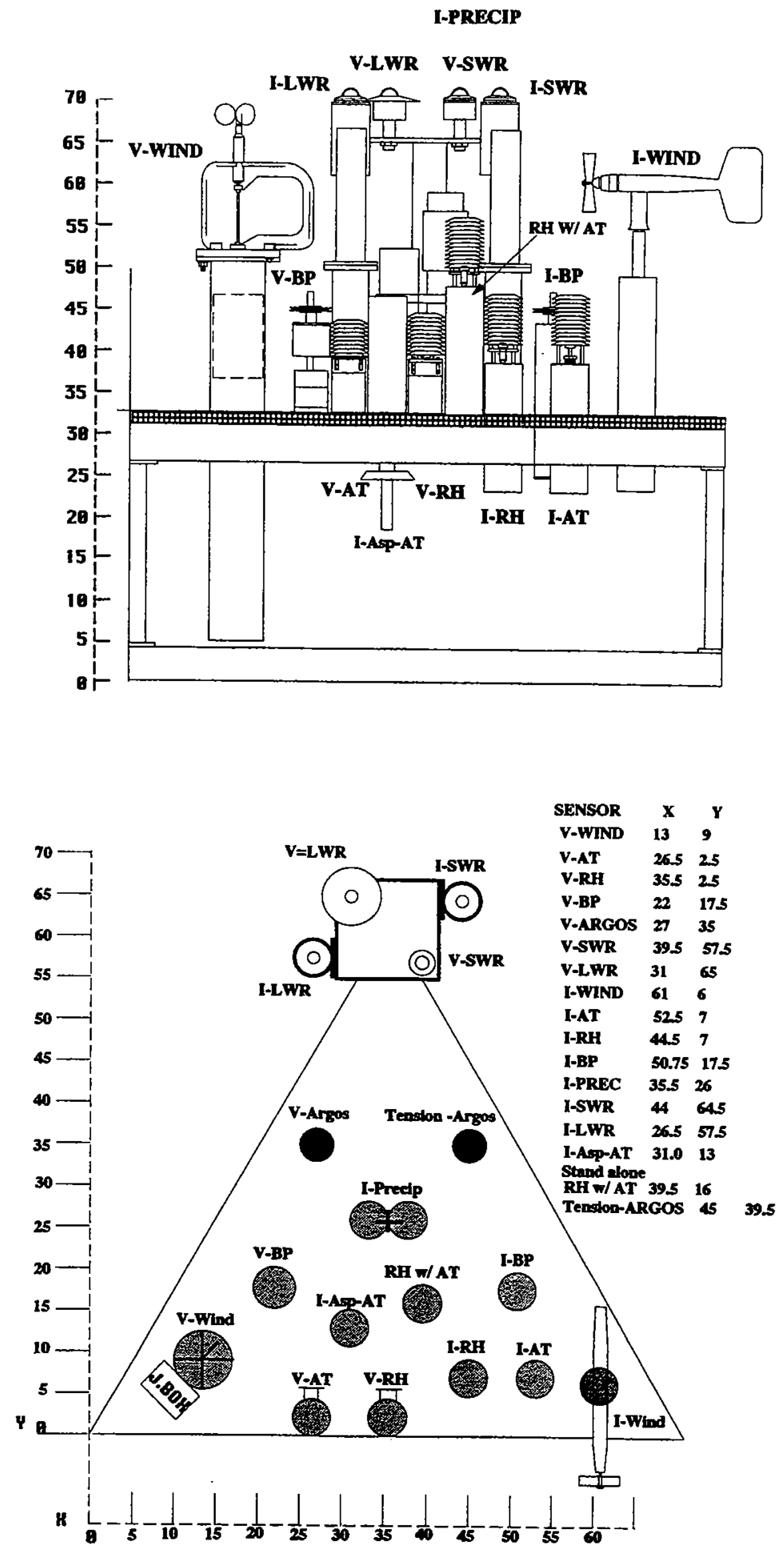

Figure 3. Buoy tower top configuration. 


\section{Oceanographic}

Subsurface instrumentation measured water temperature, conductivity, currents, dissolved oxygen, photosynthetically available radiation (PAR), light transmission and natural and stimulated fluorescence (Table 5; Figures 4 and 5). Brancker temperature sensors (Richard Brancker Research, Ltd.) were deployed in a near-surface array at depths of 0.17, 0.43, 0.92, 1.37 (first deployment only), 1.41, 1.91 and $2.42 \mathrm{~m}$. Each of these sensors was enclosed in a multi-plate radiation shield to reduce solar heating. Twelve more Brancker temperature sensors were deployed along the mooring line at depths of 4.5, 20, 30, 40, 50, 60, 72.5, 90, 125, 175, 225 and $300 \mathrm{~m}$. All of the Branckers sampled a single point measurement every 15 minutes.

Both conductivity and temperature were measured using five Seacat instruments (SeaBird, Inc.). The shallowest was mounted on the buoy bridle at a depth of $1.42 \mathrm{~m}$ while the remaining instruments were deployed along the mooring line at depths of 100,150, 200 and $250 \mathrm{~m}$. The Seacats sampled a single point measurement every 7.5 minutes.

A total of five Vector Measuring Current Meters (VMCM) (Weller and Davis, 1980) were deployed to measure horizontal water velocity and temperature. The VMCMs were deployed inline at 5, 15, 25, 45 and $55 \mathrm{~m}$ depth. Each VMCM recorded current and temperature measurements every 3.75 minutes. A description of the VMCM sampling scheme is provided in Appendix C. Five additional VMCMs were deployed on the University of Washington southeastern mooring at depths of 300, 500,750, 1500 and $3025 \mathrm{~m}$ (Table 6). The sampling rate for these instruments was 7.5 minutes.

A Pacific Marine Environmental Lab (PMEL) miniature temperature recorder (MTR) was deployed in-line at $3.5 \mathrm{~m}$ depth. This instrument sampled a single point measurement every 7.5 minutes. A Lamont-Doherty Earth Observatory (LDEO) dissolved oxygen sensor provided by Dr. Chris Langdon was mounted to the buoy bridle at a depth of $1.42 \mathrm{~m}$.

Four Multi-Variable Moored Systems (MVMS) were deployed to measure a suite of biooptical and physical parameters. Two University of California at Santa Barbara Ocean Physics Laboratory MVMS instruments were deployed at 35 and $80 \mathrm{~m}$ (Sigurdson et al., 1995, 1996). These systems measured temperature, conductivity, dissolved oxygen, current, PAR, light transmission $(660 \mathrm{~nm})$, natural fluorescence $(683 \mathrm{~nm})$ and stimulated chlorophyll fluorescence. Two LDEO MVMS instruments were deployed at 10 and $65 \mathrm{~m}$ (Ho et al., 1996, 1997). These systems measured temperature, conductivity, dissolved oxygen, current, PAR, light transmission, stimulated fluorescence and upward vertical radiance $(683 \mathrm{~nm})$. 
Table 5. Subsurface instrumentation.

\begin{tabular}{|c|c|c|c|}
\hline Depth (m) & Sensor & $\begin{array}{l}\text { Sample Interval } \\
\text { (minutes) }\end{array}$ & Parameters Measured \\
\hline 0.17 & Brancker & 15 & Temperature \\
\hline 0.43 & Brancker & 15 & Temperature \\
\hline 0.92 & Brancker & 15 & Temperature \\
\hline 1.37 & Brancker & 15 & Temperature \\
\hline 1.41 & Brancker & 15 & Temperature \\
\hline 1.42 & LDEO DO & & Dissolved oxygen \\
\hline 1.42 & Seacat & 7.5 & Temperature, Salinity \\
\hline 1.91 & Brancker & 15 & Temperature \\
\hline 2.42 & Brancker & 15 & Temperature \\
\hline 3.5 & PMEL MTR & 7.5 & Temperature \\
\hline 4.5 & Brancker & 15 & Temperature \\
\hline 5 & VMCM & 3.75 & Velocity, Temperature \\
\hline 10 & LDEO MVMS & $\begin{array}{l}4 \text { ( } 7.5 \text { for } \\
\text { velocity) }\end{array}$ & $\begin{array}{l}\text { Temperature, Salinity, Velocity, PAR, } \\
\text { Dissolved Oxygen, Light Transmission, Natural } \\
(683 \mathrm{~nm}) \text { and Stimulated Fluorescence }\end{array}$ \\
\hline 15 & VMCM & 3.75 & Velocity, Temperature \\
\hline 20 & Brancker & 15 & Temperature \\
\hline 25 & VMCM & 3.75 & Velocity, Temperature \\
\hline 30 & Brancker & 15 & Temperature \\
\hline 35 & UCSB MVMS & 3.75 & $\begin{array}{l}\text { Temperature, Salinity, Velocity, PAR, } \\
\text { Dissolved Oxygen and DO temperature, Light } \\
\text { Transmission, Natural (683nm) and Stimulated } \\
\text { Fluorescence }\end{array}$ \\
\hline 40 & Bio-Acoustic & 60 & Acoustic backscattering \\
\hline 40 & Brancker & 15 & Temperature \\
\hline 45 & VMCM & 3.75 & Velocity, Temperature \\
\hline 50 & Brancker & 15 & Temperature \\
\hline 55 & VMCM & 3.75 & Velocity, Temperature \\
\hline 60 & Brancker & 15 & Temperature \\
\hline 65 & LDEO MVMS & $\begin{array}{l}4 \text { ( } 7.5 \text { for } \\
\text { velocity) }\end{array}$ & $\begin{array}{l}\text { Temperature, Salinity, Velocity, PAR, } \\
\text { Dissolved Oxygen, Light Transmission, Natural } \\
\text { (683nm) and Stimulated Fluorescence }\end{array}$ \\
\hline 72.5 & Brancker & 15 & Temperature \\
\hline 80 & UCSB MVMS & 3.75 & $\begin{array}{l}\text { Temperature, Salinity, Velocity, PAR, } \\
\text { Dissolved Oxygen and DO temperature, Light } \\
\text { Transmission, Natural (683nm) and Stimulated } \\
\text { Fluorescence }\end{array}$ \\
\hline 90 & Brancker & 15 & Temperature \\
\hline 100 & Seacat & 7.5 & Temperature, Salinity \\
\hline 125 & Brancker & 15 & Temperature \\
\hline 150 & Seacat & 7.5 & Temperature, Salinity \\
\hline 175 & Brancker & 15 & Temperature \\
\hline 200 & Seacat & 7.5 & Temperature, Salinity \\
\hline 225 & Brancker & 15 & Temperature \\
\hline 250 & Seacat & 7.5 & Temperature, Salinity \\
\hline 300 & Brancker & 15 & Temperature \\
\hline
\end{tabular}




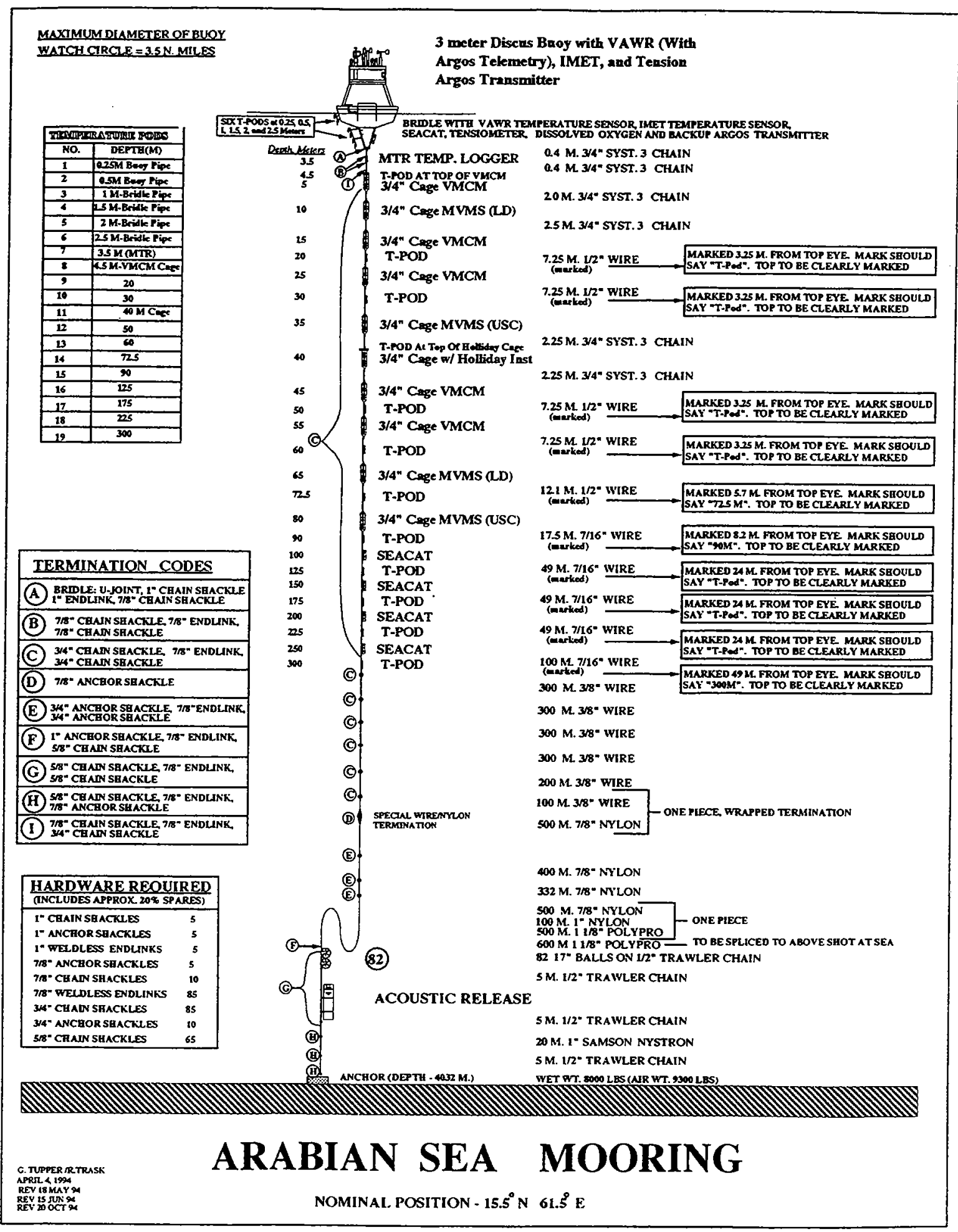

Figure 4. Mooring schematic showing subsurface instrumentation. 


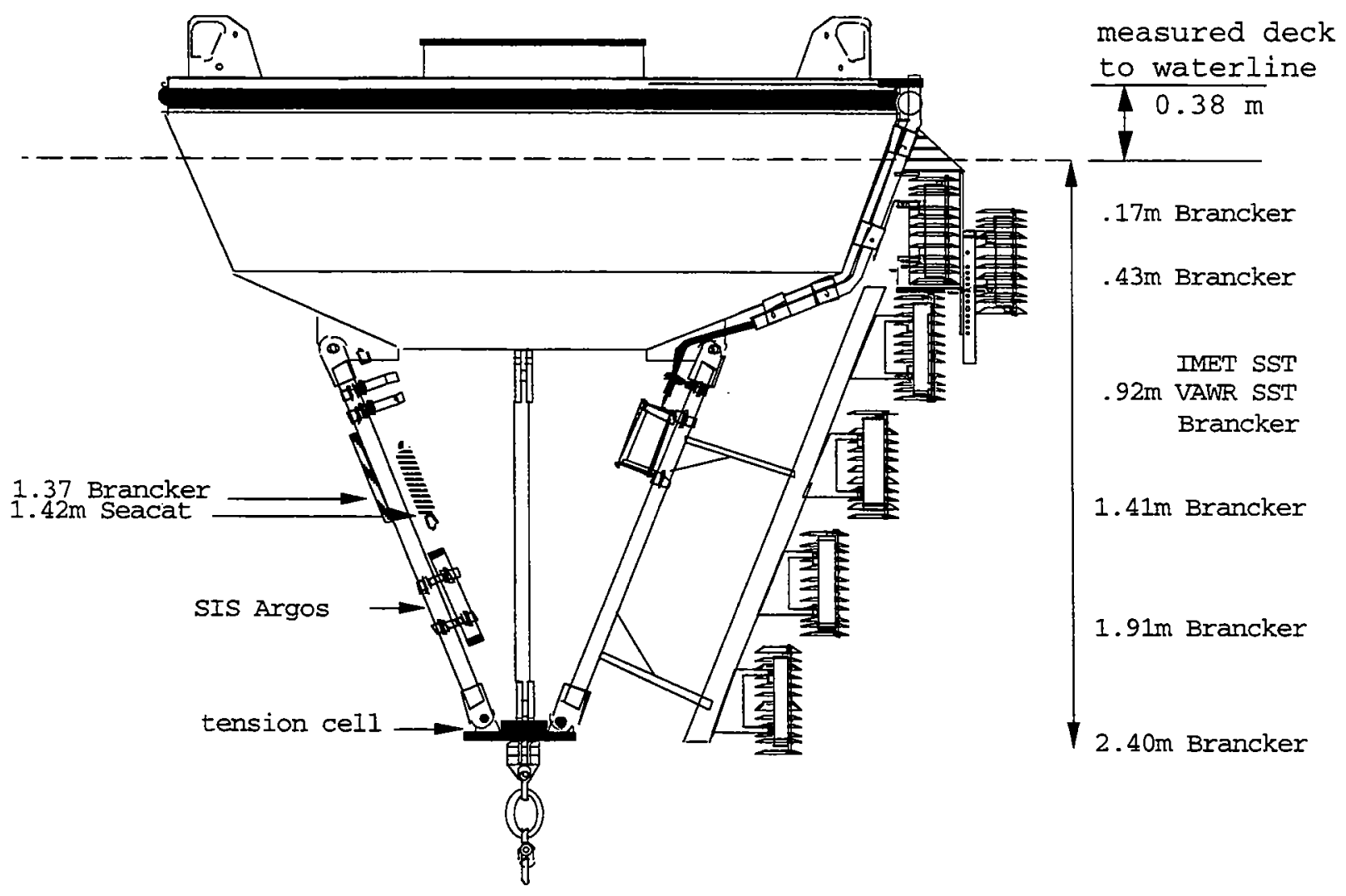

Figure 5. Discus buoy bridle instrumentation. 
Table 6. WHOI subsurface instrumentation deployed on the UW moorings.

\begin{tabular}{cccl}
\hline Depth & Sensor & $\begin{array}{c}\text { Sample Interval } \\
\text { (minute) }\end{array}$ & Parameters Measured \\
\hline $\begin{array}{c}\text { UW North } \\
20.0\end{array}$ & Brancker & 15.0 & Temperature \\
250.0 & Brancker & 15.0 & Temperature \\
& & & \\
UW South & & & \\
20.0 & Brancker & 15.0 & Temperature \\
250.0 & Brancker & 15.0 & Temperature \\
300.0 & VMCM & 7.5 & Velocity, Temperature \\
500.0 & VMCM & 7.5 & Velocity, Temperature \\
750.0 & VMCM & 7.5 & Velocity, Temperature \\
1500.0 & VMCM & 7.5 & Velocity, Temperature \\
3025.0 & VMCM & 7.5 & Velocity, Temperature \\
\hline
\end{tabular}




\section{Section 3: Data Processing}

\section{Data Return}

The following tables show the percentage of time that a particular instrument was returning good data for both deployments. Data return for the meteorological instruments is provided in Table 7 while data return for the oceanographic instrumentation is provided in tables 8 through 11 .

Table 7. Data return (percent) of meteorological instruments.

\begin{tabular}{lrr}
\hline \hline & Arab 1 & Arab 2 \\
\hline VAWR & 100 & 100 \\
Wind speed/direction & 100 & 100 \\
Sea surface temperature & 100 & 100 \\
Air temperature & 100 & 0 \\
Barometric pressure & 100 & 100 \\
Relative humidity & 100 & 100 \\
Incoming short-wave radiation & 100 & 100 \\
Incoming long-wave radiation & & \\
& & \\
IMET & 100 & 100 \\
Wind speed/direction & 100 & 100 \\
Sea surface temperature & 100 & 100 \\
Air temperature & 100 & 100 \\
Barometric pressure & 100 & 100 \\
Relative humidity & 100 & 100 \\
Incoming short-wave radiation & 100 & 100 \\
Incoming long-wave radiation & 100 & 100 \\
Precipitation & & \\
& & \\
Stand-alone & 100 & 100 \\
Air temperature & 100 & 100 \\
Relative humidity & & \\
\hline
\end{tabular}

Table 8. Data return (percent) of temperature measurements.

\begin{tabular}{ccrrr}
\hline \hline & & & & \\
Depth (m) & Instrument & Arab 1 & Arab 2 & Total \\
\hline 0.17 & Brancker & 100 & 100 & 100 \\
0.43 & Brancker & 100 & 100 & 100 \\
0.92 & Brancker & 69 & 100 & 84 \\
1.37 & Brancker & 100 & - & 100 \\
1.41 & Brancker & 100 & 100 & 100 \\
1.42 & Seacat & 100 & 100 & 100 \\
1.91 & Brancker & 100 & 100 & 100 \\
2.42 & Brancker & 100 & 100 & 100 \\
3.5 & MTR & 100 & 100 & 100 \\
4.5 & Brancker & 100 & 100 & 100 \\
5 & VMCM & 100 & 100 & 100 \\
10 & MVMS & 99 & 100 & 99 \\
15 & VMCM & 100 & 100 & 100 \\
20 & Brancker & 100 & 100 & 100 \\
25 & VMCM & 100 & 100 & 100 \\
30 & Brancker & 100 & 100 & 100 \\
35 & MVMS & 100 & 100 & 100 \\
40 & Brancker & 100 & 100 & 100 \\
45 & VMCM & 100 & 96 & 98 \\
50 & Brancker & 100 & 100 & 100 \\
55 & VMCM & 100 & 100 & 100 \\
60 & Brancker & 100 & 100 & 100 \\
65 & MVMS & 99 & 100 & 99 \\
72.5 & Brancker & 23 & 0 & 12 \\
80 & MVMS & 100 & 100 & 100 \\
90 & Brancker & 100 & 100 & 100 \\
100 & Seacat & 100 & 100 & 100 \\
125 & Brancker & 100 & 100 & 100 \\
150 & Seacat & 78 & 100 & 89 \\
175 & Brancker & 100 & 100 & 100 \\
200 & Seacat & 100 & 100 & 100 \\
225 & Brancker & 100 & 100 & 100 \\
250 & Seacat & 100 & 100 & 100 \\
300 & Brancker & 100 & 0 & 51 \\
\hline Note: No temperature sensor was deployed at & $1.37 \mathrm{~m}$ \\
during & Arab 2. & & & \\
& & & &
\end{tabular}


Table 9. Data return (percent) of temperature measurements on UW moorings.

\begin{tabular}{|c|c|c|c|c|c|c|c|c|c|}
\hline Depth (m) & Instrument & Arab 1 & Arab 2 & Total & & & & & \\
\hline \multicolumn{10}{|l|}{ UW North } \\
\hline $\begin{array}{r}20 \\
250\end{array}$ & Brancker & 72 & - & 36 & \multicolumn{5}{|c|}{ Table 11. Data return (percent) of currents. } \\
\hline \multicolumn{5}{|l|}{$\underline{U W}$ South } & Depth (m) & Instrument & Arab 1 & Arab 2 & Total \\
\hline 20 & Brancker & 52 & 100 & 75 & 5 & VMCM & 100 & 100 & 100 \\
\hline 250 & Brancker & 100 & 100 & 100 & 10 & MVMS & 82 & 100 & 91 \\
\hline 300 & VMCM & 0 & 100 & 48 & 15 & VMCM & 100 & 100 & 100 \\
\hline 500 & VMCM & 0 & 100 & 48 & 25 & VMCM & 100 & 100 & 100 \\
\hline 750 & VMCM & 100 & 100 & 100 & 35 & MVMS & 100 & 100 & 100 \\
\hline 1500 & VMCM & 100 & 100 & 100 & 45 & VMCM & 100 & 100 & 100 \\
\hline 3000 & VMCM & 100 & 100 & 100 & 55 & VMCM & 100 & 100 & 100 \\
\hline \multirow{4}{*}{\multicolumn{5}{|c|}{$\begin{array}{l}\text { Note: The UW Northeast mooring broke free on } 15 \\
\text { July } 1995 .\end{array}$}} & 65 & MVMS & 95 & 100 & 97 \\
\hline & & & & & 80 & MVMS & 100 & 100 & 100 \\
\hline & & & & & 300 & VMCM & 98 & 98 & 98 \\
\hline & & & & & 500 & VMCM & 0 & 98 & 48 \\
\hline \multirow{2}{*}{\multicolumn{5}{|c|}{$\begin{array}{l}\text { Table 10. Data return (percent) of salinity } \\
\text { (conductivity) measurements. }\end{array}$}} & 750 & VMCM & 86 & 98 & 92 \\
\hline & & & & & 1500 & VMCM & 5 & 0 & 2 \\
\hline \multirow[b]{2}{*}{ Depth (m) } & & & & & 3000 & VMCM & 0 & 0 & 0 \\
\hline & Instrument & Arab 1 & Arab 2 & Total & \multirow{10}{*}{\multicolumn{5}{|c|}{$\begin{array}{l}\text { Note: VMCMs at and below } 300 \mathrm{~m} \text { are from the } \mathrm{UW} \\
\text { southeast mooring. }\end{array}$}} \\
\hline 1.8 & Seacat & 100 & 100 & 100 & & & & & \\
\hline 10 & MVMS & 69 & 78 & 74 & & & & & \\
\hline 35 & MVMS & 98 & 53 & 76 & & & & & \\
\hline 65 & MVMS & 99 & 47 & 73 & & & & & \\
\hline 80 & MVMS & 0 & 100 & 49 & & & & & \\
\hline 100 & Seacat & 100 & 100 & 100 & & & & & \\
\hline 150 & Seacat & 73 & 100 & 86 & & & & & \\
\hline 200 & Seacat & 100 & 100 & 100 & & & & & \\
\hline 250 & Seacat & 100 & 100 & 100 & & & & & \\
\hline
\end{tabular}

\section{Processing}

The raw VAWR and subsurface data were processed using the WHOI UOP software package (Prada, 1992). Pre-deployment calibrations were applied to each instrument initially and post-deployment calibrations were only used when the post-deployment calibrations yielded better agreement during intercomparisons with other sensors. All calibrated data were converted to EPIC-compliant NetCDF files (Denbo and Zhu, 1993; Rew et al., 1993).

After initial processing, qualitative checks were performed on the data to identify sensor problems such as spikes, drop-outs or gross errors. Subsequent intercomparisons with other buoy and shipboard instruments revealed time dependent problems, linear biases and offsets in some 
sensors. Empirical adjustments were applied to the data to improve agreement among these collocated sensors. These adjustments are summarized in Tables 12-17.

Solar radiative heating errors occur in air temperature measurements when the sensor itself or its housing is heated by the sun. All of the temperature sensors deployed in the Arabian Sea except the IMET aspirated module were housed in Gill multi-plate radiation shields (Gill, 1983) which reduce radiative heating errors, but do not eliminate them. The aspirated air temperature was fan-aspirated at $3 \mathrm{~m} \mathrm{~s}^{-1}$ and was specified to have an error of no more than $\pm 0.2^{\circ} \mathrm{C}$ under $1080 \mathrm{~W} \mathrm{~m}^{-2}$ heating. Differences between the shielded and aspirated daytime air temperatures were attributed to solar radiative heating and these errors were detected in all of the shielded air temperature measurements. A detailed analysis of radiative heating was possible (Anderson and

Table 12. Processing and edits of meteorological data.

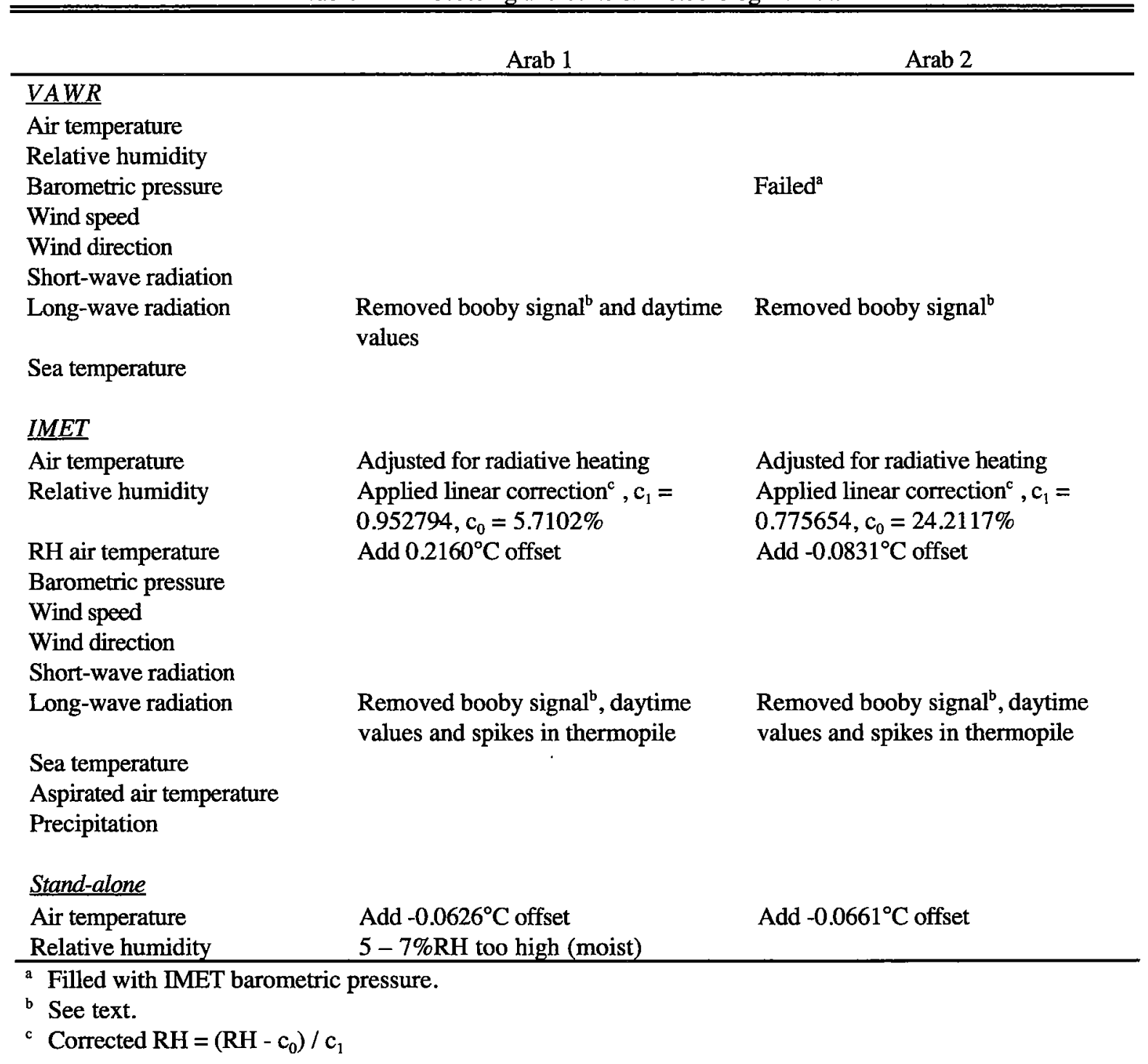


Table 13. Processing and edits of temperature data.

\begin{tabular}{|c|c|c|c|}
\hline Depth (m) & Sensor & Arab 1 & Arab 2 \\
\hline 0.17 & Brancker & & Add $0.0314^{\circ} \mathrm{C}$ offset \\
\hline 0.43 & Brancker & & \\
\hline 0.92 & Brancker & Failed on 22 Feb 95 & \\
\hline 1.37 . & Brancker & & No sensor deployed at this depth \\
\hline 1.41 & Brancker & & \\
\hline 1.42 & Seacat & & \\
\hline 1.91 & Brancker & & \\
\hline 2.42 & Brancker & & \\
\hline 3.5 & PMEL MTR & & \\
\hline 4.5 & Brancker & & \\
\hline 5 & VMCM & & \\
\hline 10 & LDEO MVMS & & \\
\hline 15 & VMCM & & \\
\hline 20 & Brancker & & \\
\hline 25 & VMCM & & \\
\hline 30 & Brancker & & \\
\hline 35 & UCSB MVMS & Add $0.049^{\circ} \mathrm{C}$ offset & Add $0.193^{\circ} \mathrm{C}$ offset \\
\hline 40 & Brancker & & \\
\hline 45 & VMCM & & Several hot spikes edited \\
\hline 50 & Brancker & & Several cold spikes edited \\
\hline 55 & VMCM & & \\
\hline 60 & Brancker & & \\
\hline 65 & LDEO MVMS & & \\
\hline 72.5 & Brancker & Failed 28 Nov 94 & Failed \\
\hline 80 & UCSB MVMS & Add $0.055^{\circ} \mathrm{C}$ offset & \\
\hline 90 & Brancker & & \\
\hline 100 & Seacat & & \\
\hline 125 & Brancker & & \\
\hline 150 & Seacat & Failed on 10 Mar 1995 & \\
\hline 175 & Brancker & & \\
\hline 200 & Seacat & & \\
\hline 225 & Brancker & & \\
\hline 250 & Seacat & & \\
\hline 300 & Brancker & & Failed $^{b}$ \\
\hline $300^{\mathrm{a}}$ & VMCM & Failed & \\
\hline $500^{\mathrm{a}}$ & VMCM & Failed & \\
\hline $750^{\mathrm{a}}$ & VMCM & & \\
\hline $1500^{\mathrm{a}}$ & VMCM & & \\
\hline $3025^{\mathrm{a}}$ & VMCM & & \\
\hline
\end{tabular}

${ }^{\mathrm{a}}$ From the UW southeast mooring.

${ }^{b}$ Filled with UW southeast $300 \mathrm{~m}$ VMCM temperature data 
Table 14. Processing and edits of salinity data.

\begin{tabular}{cccl}
\hline \hline & & & \\
Depth $(\mathrm{m})$ & Sensor & Arab 1 & Arab 2 \\
\hline 1.42 & Seacat & & \\
10 & MVMS & 16 Jan 95 1340-12 Mar 95 0340 discarded & Failed on 10 Sep 95 0945 \\
35 & MVMS & 17 Jan 95 0430-20 Jan 95 1300 discarded & Failed on 28 Jul 95 0000 \\
65 & MVMS & & 23 Apr 95 2007 - 28 Jul 95 0100 discarded \\
80 & MVMS & & \\
100 & Seacat & & \\
150 & Seacat & Failed on 28 Feb 95 & \\
200 & Seacat & & \\
250 & Seacat & & \\
\hline
\end{tabular}

Table 15. Offsets applied to Arab 1 LDEO $10 \mathrm{~m}$ MVMS and UCSB $35 \mathrm{~m}$ MVMS salinity during various periods*

\begin{tabular}{cccc}
\hline \hline & & & \\
Depth $(\mathrm{m})$ & Start of Period & End of Period & Offset (PSU) \\
\hline 10 & 14 Dec 94 0223 & 17 Jan 95 0416 & 0.1165 \\
10 & 11 Mar 95 1609 & 17 Apr 95 2207 & 0.4500 \\
35 & 12 Dec 94 2151 & 17 Jan 95 0416 & 0.1893 \\
35 & 20 Jan 95 1306 & 20 Apr 95 1642 & 0.4141 \\
\hline
\end{tabular}

${ }^{*}$ Corrected salinity $=$ salinity + offset

Table 16. Constants for 10m LDEO MVMS time dependent salinity drift correction* ${ }^{*}$.

\begin{tabular}{lcccc}
\hline \hline Deployment & Start of Period & End of Period & $c_{1}$ (PSU day $\left.{ }^{-1}\right)$ & $c_{0}$ (PSU) \\
\hline Arab 1 & 16 Nov 94 0845 & 14 Dec 94 0215 & 0.0090456 & 0.0153 \\
Arab 2 & 5 Jul 95 0500 & 11 Sep 95 1900 & 0.0067624 & 0.0380 \\
\hline
\end{tabular}

* Corrected salinity $=$ salinity $+\left[c_{1}\right.$ (number of days since start of period) $\left.+c_{0}\right]$ 
Table 17. Processing and edits of current data.

\begin{tabular}{|c|c|c|c|}
\hline Depth (m) & Sensor & Arab 1 & Arab 2 \\
\hline 5 & VMCM & & \\
\hline 10 & LDEO MVMS & Rotated $18.71^{\circ}$ east of north & Rotated $18.71^{\circ}$ east of north \\
\hline 15 & VMCM & & \\
\hline 25 & VMCM & & \\
\hline 35 & UCSB MVMS & & \\
\hline 45 & VMCM & & \\
\hline 55 & VMCM & & \\
\hline 65 & LDEO MVMS & Rotated $18.71^{\circ}$ east of north & Rotated $18.71^{\circ}$ east of north \\
\hline 80 & UCSB MVMS & & \\
\hline 300 & VMCM & & \\
\hline 500 & VMCM & Failed & \\
\hline 750 & VMCM & Compass failed on 25 Mar 952307 & \\
\hline 1500 & VMCM & Failed & Failed \\
\hline 3025 & VMCM & Failed & Failed \\
\hline
\end{tabular}

Baumgartner, 1997) due to the availability of so many collocated air temperature measurements (i.e., VAWR, IMET, IMET aspirated, IMET relative humidity/air temperature module and the stand-alone relative humidity/air temperature module). This analysis yielded a model of heat exchange that could be used with empirically derived constants to adjust air temperatures for radiative heating errors. Since the IMET aspirated air temperature module was designed to operate for only the first two months of each six month deployment due to power constraints, the IMET air temperature measurements were adjusted for radiative heating errors to provide a complete time series of air temperature for the buoy. This time series of adjusted air temperature was used in the bulk aerodynamic formulae to derive heat fluxes (described below).

The IMET incoming long-wave radiation was contaminated by daytime errors roughly proportional to incoming short-wave during both deployments. The VAWR pyrgeometer showed similar errors during the first deployment. These errors are, as yet, unexplained and no simple empirical correction was determined. All of the deployed pyrgeometers were designed to account for daytime heating by measuring both body and dome temperatures, so these errors are unrelated to daytime heating of the sensor. An anomalous diurnal signal in the thermopile output voltage seems to be responsible for the daytime errors. The Arab 1 VAWR daytime long-wave measurements were replaced by values linearly interpolated in time between the median long-wave radiation one hour before sunrise and one hour after sunset. The adjusted Arab 1 VAWR and the uncontaminated Arab 2 VAWR long-wave measurements were used in the bulk aerodynamic formulae. 
Based on observations during recovery and a qualitative analysis of both long-wave time series, it was determined that a bird (tentatively identified as a booby during recovery) alternately sat on the VAWR and IMET pyrgeometers during the inter-monsoon periods (Figure 6). Apparently the IMET pyrgeometer provides a more comfortable seat for a booby, since the bird spent almost three times more time on the IMET sensor (93 hours) than on the VAWR ( 33 hours). This signal was replaced by values linearly interpolated in time between the average long-wave radiation one-half hour before the booby sat down and one-half hour after it got up.

The 10 and $35 \mathrm{~m}$ MVMS salinity (conductivity) measurements were suspect at many times during the one year experiment. A significant effort was invested in recovering these salinity measurements, since the shallowest salinity observations after the $1.42 \mathrm{~m}$ Seacat were from the $65 \mathrm{~m}$ LDEO MVMS. The variability in the salinity measurements at 10 and $35 \mathrm{~m}$ often matched that of the 1.42 or $65 \mathrm{~m}$, but offsets were detected. The $10 \mathrm{~m}$ MVMS seemed to have time dependent drifts in some instances. To determine offsets and drifts, the 10 and $35 \mathrm{~m}$ MVMS salinity measurements were compared to an 'expected' salinity that was interpolated in temperature/salinity space from the $1.42 \mathrm{~m}$ Seacat and the $65 \mathrm{~m}$ MVMS. This approach assumed that the 1.42 and $65 \mathrm{~m}$ temperature and salinity observations are from the same water mass and are conservative. The latter assumption is not a very good one for the surface Seacat, so this analysis is quite crude. However, the aim of the adjustment was to preserve the observed variability in the 10 and $35 \mathrm{~m}$ measurements and to shift the mean values so that they agree with surrounding sensors and make sense in context with their corresponding temperature measurements. The resulting time series of vertical density distribution yields few inversions over the entire year which suggests that the adjustments were reasonable.

All current meters had a magnetic variation correction of $-0.79^{\circ}$ (west of north) applied. A magnetic variation of $-19.5^{\circ}$ had been applied to the LDEO MVMS current measurements during calibration on the advice of the University of Washington, however this was incorrect. A rotation of $18.71^{\circ}$ (east of north) was applied to the 10 and $65 \mathrm{~m}$ MVMS currents to account for the incorrect magnetic variation and to apply the true $-0.79^{\circ}$ value.

\section{Freshwater, Heat and Momentum Fluxes}

Air-sea fluxes were estimated from the meteorological and near-surface oceanographic measurements using a bulk flux algorithm developed for TOGA COARE (Fairall et al., 1996a). This algorithm is based on methods developed by Liu et al. (1979) with modifications for, but not limited to, low wind regimes. Consequently, these bulk formulae are appropriate for the low wind 


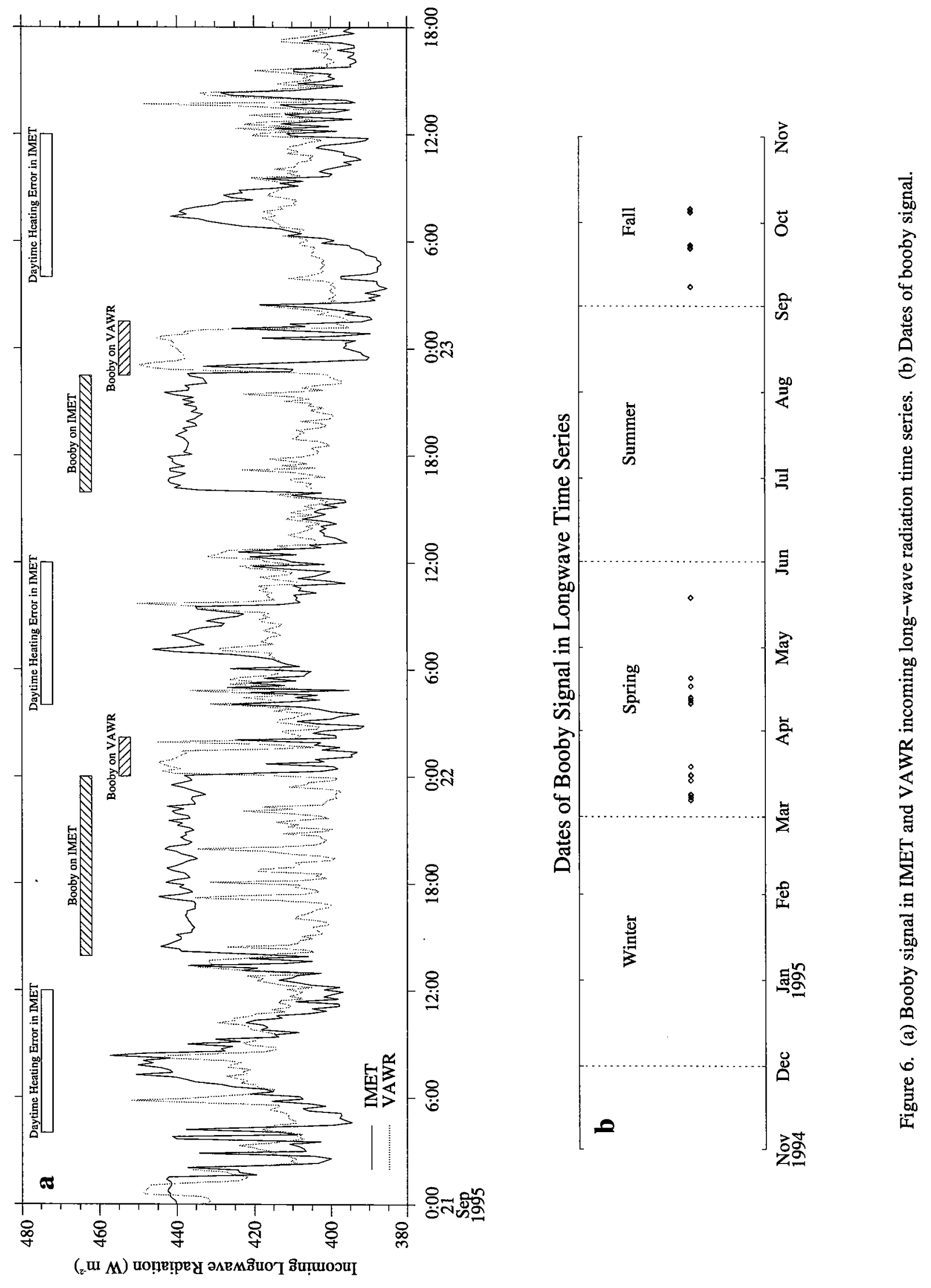


inter-monsoonal period observed during the one year deployment. The algorithm also includes cool skin and warm layer adjustments based on Fairall et al. (1996b) to account for the cooling of the upper few millimeters of the ocean due to sensible, latent and outgoing long-wave radiation heat loss and warming of the upper few meters of the ocean due to absorption of short-wave radiation. The parameters used in the bulk algorithm (version 2.5) were derived from both the VAWR and IMET meteorological packages, the $0.17 \mathrm{~m}$ Brancker temperature sensor and the $5 \mathrm{~m}$ VMCM (Table 18).

Table 18. Parameters used in bulk flux algorithm.

\begin{tabular}{lcc}
\hline \hline & & \\
Parameter & Arab 1 & Arab 2 \\
\hline Air temperature & IMET adjusted for radiative heating & IMET adjusted for radiative heating \\
Specific humidity & Computed from IMET RH & Computed from IMET RH \\
Barometric pressure & VAWR & IMET \\
Incoming short-wave radiation & VAWR & VAWR \\
Incoming long-wave radiation & VAWR & VAWR \\
Sea surface temperature & 0.17 m Brancker & 0.17 m Brancker \\
Wind speed/direction relative to & VAWR wind speed relative to 5 m & VAWR wind speed relative to 5 m \\
\multicolumn{1}{c}{ surface current } & VMCM current & VMCM current \\
\hline
\end{tabular}

Since only incoming short- and long-wave radiation were measured, the outgoing components of radiation were estimated. Surface albedo was derived from the atmospheric transmittance and solar elevation angle using Payne's algorithm (1972). The atmospheric transmittance was estimated from the difference between the theoretical clear sky radiation (List, 1984) and the observed incoming short-wave radiation on a cloud-free day. The atmospheric transmittance determined from the VAWR pyranometer was 0.72 . Outgoing long-wave radiation was estimated as $\varepsilon \sigma T^{4}$ where $\varepsilon$ is the emissivity of the sea surface $(\varepsilon=0.97), \sigma$ is the StefanBoltzmann constant and $\mathrm{T}$ is the sea surface temperature in ${ }^{\circ} \mathrm{K}$. The skin temperature from the cool skin adjustment was used as the sea surface temperature, since the outgoing long-wave radiation is dependent on the interfacial temperature which may be quite different from the shallowest temperature measurement at $0.17 \mathrm{~m}$. 


\section{Section 4: Data Summary}

Yearly statistics of the meteorological measurements and estimated heat, momentum and freshwater fluxes are presented in Table 19 and monthly statistics are provided in Tables 20-32. Each table contains the mean, standard deviation, minimum and maximum of the meteorological measurements and fluxes. Yearly time series of the meteorological observations are presented in Figure 7 and monthly time series are provided in Figures 8-20. A yearly time series of precipitation and evaporation are shown in Figure 21. Yearly time series of the heat and momentum fluxes are presented in Figure 22 and monthly time series are provided in Figures 2335.

Yearly and monthly contour plots of subsurface temperature are presented in Figure 36 and Figures 37-49, respectively. The mixed layer depth in these plots was computed as the depth at which the temperature differs from the sea surface temperature (measured at $0.17 \mathrm{~m}$ ) by $0.1^{\circ} \mathrm{C}$. Stick plots depicting the VMCM and MVMS currents are presented in Figures 50 and 51. Monthly stick plots of velocity with current speed overlaid are presented in Figures 52-64. Integrated velocity for the current meters between 5 and $80 \mathrm{~m}$ are presented as progressive vector diagrams in Figure 65 (integrated over the entire year) and Figure 66 (integrated over each month).

Autospectra of the meteorological measurements and heat and momentum fluxes are presented in Figures 67 and 68, respectively. Rotary autospectra are presented for vector quantities (i.e., wind and wind stress). Autospectra of temperature and rotary autospectra of velocity at various depths are presented in Figures 69 and 70, respectively. Band averaging was used in each of the autospectra plots and the $95 \%$ confidence limits are shown. The first 5 frequencies were averaged over 3 bands and the number of bands averaged was doubled every 10 frequencies thereafter (i.e., frequencies 6-15 were averaged over 6 bands, frequencies 16-25 were averaged over 12 bands, frequencies 26-35 were averaged over 24 bands, etc.). 
Table 19. Statistics of observables and fluxes for the entire deployment.

\begin{tabular}{|c|c|c|c|c|c|}
\hline Variable & Unit & Mean & Std. Dev. & Minimum & Maximum \\
\hline Air temperature & ${ }^{\circ} \mathrm{C}$ & 26.65 & 1.63 & 22.60 & 31.47 \\
\hline Relative humidity & $\%$ & 77.4 & 9.2 & 47.3 & 97.7 \\
\hline Barometric pressure & mbar & 1010.4 & 4.5 & 997.0 & 1020.3 \\
\hline East wind & $\mathrm{m} \mathrm{s}^{-1}$ & 1.35 & 5.73 & -14.78 & 14.82 \\
\hline North wind & $\mathrm{m} \mathrm{s}^{-1}$ & 0.13 & 4.27 & -10.66 & 16.32 \\
\hline Wind speed $^{\mathrm{a}}$ & $\mathrm{m} \mathrm{s}^{-1}$ & 6.50 & 3.27 & 0.04 & 18.34 \\
\hline Wind direction ${ }^{\mathrm{b}}$ & $\circ$ & 157 & 0 & 0 & 0 \\
\hline Wind speed & $\mathrm{m} \mathrm{s}^{-1}$ & 1.35 & 0.00 & 0.00 & 0.00 \\
\hline Wind direction ${ }^{\mathrm{d}}$ & $\circ$ & 84 & 0 & 0 & 0 \\
\hline Incoming short-wave radiation & $\mathrm{W} \mathrm{m^{-2 }}$ & 258.0 & 341.4 & -0.7 & 1214.7 \\
\hline Incoming long-wave radiation & $\mathrm{W} \mathrm{\textrm {m } ^ { - 2 }}$ & 400.0 & 29.7 & 335.2 & 506.5 \\
\hline Sea surface temperature ${ }^{e}$ & ${ }^{\circ} \mathrm{C}$ & 27.24 & 1.57 & 24.58 & 32.23 \\
\hline Specific humidity & $\mathrm{g} \mathrm{kg}^{-1}$ & 16.83 & 2.94 & 8.59 & 22.64 \\
\hline Precipitation rate & $\mathrm{mm} \mathrm{hr}^{-1}$ & 0.0053 & 0.2690 & 0.0000 & 38.5243 \\
\hline Evaporation rate & $\mathrm{mm} \mathrm{hr}^{-1}$ & 0.1800 & 0.0831 & 0.0117 & 0.5516 \\
\hline Evaporation rate - precipitation rate & $\mathrm{mm} \mathrm{hr}$ & 0.1747 & 0.2817 & -38.4665 & 0.5516 \\
\hline Wind stress & $\mathrm{N} \mathrm{m}^{-2}$ & 0.1007 & 0.1085 & 0.0001 & 0.8772 \\
\hline Sensible heat flux & $\mathrm{W} \mathrm{m} \mathrm{m}^{-2}$ & -1.7 & 6.6 & -55.4 & 25.9 \\
\hline Latent heat flux & $\mathrm{W} \mathrm{m} \mathrm{m}^{-2}$ & -122.6 & 56.6 & -375.8 & -7.9 \\
\hline Net short-wave radiation & $\mathrm{W} \mathrm{m} \mathrm{m}^{-2}$ & 243.3 & 328.6 & -0.2 & 1170.0 \\
\hline Net long-wave radiation & $\mathrm{W} \mathrm{m} \mathrm{m}^{-2}$ & -58.7 & 26.2 & -109.6 & 26.8 \\
\hline Net heat flux & $\mathrm{W} \mathrm{m} \mathrm{m}^{-2}$ & 60.3 & 335.7 & -498.0 & 1011.4 \\
\hline Skin temperature $^{\mathrm{f}}$ & ${ }^{\circ} \mathrm{C}$ & 27.03 & 1.58 & 24.52 & 32.17 \\
\hline $10 \mathrm{~m}$ wind speed ${ }^{\mathrm{g}}$ & $\mathrm{m} \mathrm{s}^{-1}$ & 7.12 & 3.64 & 0.09 & 20.30 \\
\hline $2 \mathrm{~m}$ air temperature $\mathrm{g}$ & ${ }^{\circ} \mathrm{C}$ & 26.67 & 1.63 & 22.65 & 31.47 \\
\hline $2 \mathrm{~m}$ relative humidity $\mathrm{g}$ & $\%$ & 78.0 & 8.7 & 48.1 & 99.2 \\
\hline $2 \mathrm{~m}$ specific humidity ${ }^{\mathrm{g}}$ & $\mathrm{g} \mathrm{kg}^{-1}$ & 16.95 & 2.91 & 8.78 & 22.74 \\
\hline
\end{tabular}

a Scalar averaged

b Vector averaged from components of a unit vector oriented in the direction of the wind

c Vector averaged

${ }^{d}$ Computed as the arctangent of the average east and north components

e Measured at $0.17 \mathrm{~m}$ depth

f The temperature of the upper few millimeters of the ocean. Computed from Fairall et al. (1996b)

g Estimated from boundary layer profiles in flux algorithm 
Table 20. Statistics of observables and fluxes for October 1994.

\begin{tabular}{|c|c|c|c|c|c|}
\hline Variable & Unit & Mean & Std. Dev. & Minimum & Maximum \\
\hline Air temperature & ${ }^{\circ} \mathrm{C}$ & 27.24 & 0.43 & 24.88 & 28.53 \\
\hline Relative humidity & $\%$ & 77.0 & 7.9 & 49.9 & 97.7 \\
\hline Barometric pressure & mbar & 1011.6 & 1.5 & 1004.9 & 1015.1 \\
\hline East wind & $\mathrm{m} \mathrm{s}^{-1}$ & -3.49 & 1.98 & -14.78 & 4.56 \\
\hline North wind & $\mathrm{m} \mathrm{s}^{-1}$ & -2.54 & 2.86 & -10.66 & 16.32 \\
\hline Wind speed ${ }^{\mathrm{a}}$ & $\mathrm{m} \mathrm{s}^{-1}$ & 5.29 & 1.67 & 1.63 & 17.39 \\
\hline Wind direction ${ }^{\mathrm{b}}$ & $\circ$ & 234 & & & \\
\hline Wind speed ${ }^{c}$ & $\mathrm{~m} \mathrm{~s}^{-1}$ & 4.32 & & & \\
\hline Wind direction ${ }^{\mathrm{d}}$ & $\circ$ & 234 & & & \\
\hline Incoming short-wave radiation & $\mathrm{W} \mathrm{m}^{-2}$ & 250.5 & 344.7 & -0.2 & 1078.1 \\
\hline Incoming long-wave radiation & $W \mathrm{~m}^{-2}$ & 393.9 & 15.2 & 356.3 & 444.7 \\
\hline Sea surface temperature ${ }^{e}$ & ${ }^{\circ} \mathrm{C}$ & 27.91 & 0.21 & 27.31 & 28.41 \\
\hline Specific humidity & $\mathrm{g} \mathrm{kg}^{-1}$ & 17.55 & 1.87 & 11.19 & 20.58 \\
\hline Precipitation rate & $\mathrm{mm} \mathrm{hr} \mathrm{r}^{-1}$ & 0.0557 & 0.7195 & 0.0000 & 13.4636 \\
\hline Evaporation rate & $\mathrm{mm} \mathrm{hr} \mathbf{r}^{-1}$ & 0.1769 & 0.0555 & 0.0625 & 0.3697 \\
\hline Evaporation rate - precipitation rate & $\mathrm{mm} \mathrm{hr}{ }^{-1}$ & 0.1212 & 0.7182 & -13.1743 & 0.3697 \\
\hline Wind stress & $\mathrm{N} \mathrm{m}^{-2}$ & 0.0597 & 0.0592 & 0.0068 & 0.8772 \\
\hline Sensible heat flux & $\mathrm{W} \mathrm{m}^{-2}$ & -3.9 & 4.4 & -55.4 & 4.2 \\
\hline Latent heat flux & $W \mathrm{~m}^{-2}$ & -120.5 & 37.8 & -251.9 & -42.6 \\
\hline Net short-wave radiation & $W \mathrm{~m}^{-2}$ & 235.9 & 331.0 & -0.1 & 1038.7 \\
\hline Net long-wave radiation & $W \mathrm{~m}^{-2}$ & -68.4 & 14.7 & -101.9 & -17.7 \\
\hline Net heat flux & $\mathrm{W} \mathrm{m}^{-2}$ & 43.0 & 333.8 & -348.6 & 896.6 \\
\hline Skin temperature $e^{f}$ & ${ }^{\circ} \mathrm{C}$ & 27.67 & 0.24 & 27.16 & 28.26 \\
\hline $10 \mathrm{~m}$ wind speed ${ }^{\mathrm{g}}$ & $\mathrm{m} \mathrm{s}^{-1}$ & 6.17 & 1.81 & 1.99 & 20.30 \\
\hline $2 \mathrm{~m}$ air temperature $\mathrm{g}$ & ${ }^{\circ} \mathrm{C}$ & 27.26 & 0.42 & 24.94 & 28.53 \\
\hline $2 \mathrm{~m}$ relative humidity $\mathrm{g}$ & $\%$ & 79.2 & 7.8 & 52.5 & 99.2 \\
\hline $2 \mathrm{~m}$ specific humidity ${ }^{\mathrm{g}}$ & $\mathrm{g} \mathrm{kg}^{-1}$ & 17.67 & 1.84 & 11.38 & 20.63 \\
\hline
\end{tabular}

${ }^{a}$ Scalar averaged

${ }^{b}$ Vector averaged from components of a unit vector oriented in the direction of the wind

${ }^{c}$ Vector averaged

${ }^{d}$ Computed as the arctangent of the average east and north components

${ }^{\mathrm{e}}$ Measured at $0.17 \mathrm{~m}$ depth

${ }^{\mathrm{f}}$ The temperature of the upper few millimeters of the ocean. Computed from Fairall et al. (1996b)

${ }^{g}$ Estimated from boundary layer profiles in flux algorithm 
Table 21. Statistics of observables and fluxes for November 1994.

\begin{tabular}{|c|c|c|c|c|c|}
\hline Variable & Unit & Mean & Std. Dev. & Minimum & Maximum \\
\hline Air temperature & ${ }^{\circ} \mathrm{C}$ & 27.23 & 0.55 & 24.63 & 28.32 \\
\hline Relative humidity & $\%$ & 75.6 & 8.0 & 51.8 & 90.7 \\
\hline Barometric pressure & mbar & 1012.7 & 1.4 & 1009.2 & 1017.0 \\
\hline East wind & $\mathrm{m} \mathrm{s}^{-1}$ & -5.08 & 1.51 & -8.46 & 0.15 \\
\hline North wind & $\mathrm{m} \mathrm{s}^{-1}$ & -3.25 & 1.42 & -7.31 & 3.09 \\
\hline Wind speed ${ }^{\mathrm{a}}$ & $\mathrm{m} \mathrm{s}^{-1}$ & 6.26 & 1.20 & 1.40 & 10.19 \\
\hline Wind direction ${ }^{\mathrm{b}}$ & $\circ$ & 237 & & & \\
\hline Wind speed ${ }^{\mathrm{c}}$ & $\mathrm{m} \mathrm{s}^{-1}$ & 6.02 & & & \\
\hline Wind direction ${ }^{d}$ & $\circ$ & 237 & & & \\
\hline Incoming short-wave radiation & $W \mathrm{~m}^{-2}$ & 237.2 & 321.0 & -0.1 & 987.2 \\
\hline Incoming long-wave radiation & $W m^{-2}$ & 390.8 & 14.3 & 359.9 & 441.8 \\
\hline Sea surface temperature $e^{e}$ & ${ }^{\circ} \mathrm{C}$ & 27.52 & 0.51 & 26.55 & 28.34 \\
\hline Specific humidity & $\mathrm{g} \mathrm{kg}^{-1}$ & 17.01 & 2.13 & 11.83 & 20.57 \\
\hline Precipitation rate & $\mathrm{mm} \mathrm{hr}{ }^{-1}$ & 0.0099 & 0.3177 & 0.0000 & 15.8448 \\
\hline Evaporation rate & $\mathrm{mm} \mathrm{hr}^{-1}$ & 0.1998 & 0.0662 & 0.0658 & 0.4656 \\
\hline Evaporation rate - precipitation rate & $\mathrm{mm} \mathrm{hr}^{-1}$ & 0.1900 & 0.3252 & -15.6822 & 0.4656 \\
\hline Wind stress & $\mathrm{N} \mathrm{m}^{-2}$ & 0.0724 & 0.0287 & 0.0045 & 0.2089 \\
\hline Sensible heat flux & $\mathrm{W} \mathrm{m}^{-2}$ & $\cdot \quad 0.0$ & 4.0 & -34.8 & 15.8 \\
\hline Latent heat flux & $\mathrm{W} \mathrm{m} \mathrm{m}^{-2}$ & -136.2 & 45.1 & -317.2 & -44.9 \\
\hline Net short-wave radiation & $\mathrm{W} \mathrm{m}^{-2}$ & 222.1 & 307.4 & 0.0 & 949.4 \\
\hline Net long-wave radiation & $\mathrm{W} \mathrm{m} \mathrm{m}^{-2}$ & -69.1 & 12.5 & -97.5 & -20.1 \\
\hline Net heat flux & $\mathrm{W} \mathrm{m}^{-2}$ & 16.8 & 311.4 & -392.2 & 789.3 \\
\hline Skin temperature $\mathrm{f}^{\mathrm{f}}$ & ${ }^{\circ} \mathrm{C}$ & 27.29 & 0.54 & 26.22 & 28.18 \\
\hline $10 \mathrm{~m}$ wind speed ${ }^{\mathrm{g}}$ & $\mathrm{m} \mathrm{s}^{-1}$ & 7.01 & 1.41 & 1.58 & 11.35 \\
\hline $2 \mathrm{~m}$ air temperature $\mathrm{g}$ & ${ }^{\circ} \mathrm{C}$ & 27.23 & 0.55 & 24.69 & 28.32 \\
\hline $2 \mathrm{~m}$ relative humidity ${ }^{\mathrm{g}}$ & $\%$ & 76.9 & 8.1 & 53.2 & 95.2 \\
\hline $2 \mathrm{~m}$ specific humidity $\mathrm{g}$ & $\mathrm{g} \mathrm{kg}^{-1}$ & 17.14 & 2.10 & 12.08 & 20.62 \\
\hline $\begin{array}{l}\text { Scalar averaged } \\
\text { b Vector averaged from component } \\
\text { c Vector averaged } \\
\text { d Computed as the arctangent of th } \\
\text { e Measured at } 0.17 \mathrm{~m} \text { depth } \\
\text { f The temperature of the upper few } \\
\text { g Estimated from boundary laver }\end{array}$ & $\begin{array}{l}\text { unit ver } \\
\text { rage east }\end{array}$ & $\begin{array}{l}\text { oriented in } \\
\text { north com } \\
\text { e ocean. C }\end{array}$ & $\begin{array}{l}\text { lirection of } \\
\text { nts }\end{array}$ & wind & \\
\hline
\end{tabular}


Table 22. Statistics of observables and fluxes for December 1994.

\begin{tabular}{|c|c|c|c|c|c|}
\hline Variable & Unit & Mean & Std. Dev. & Minimum & Maximum \\
\hline Air temperature & ${ }^{\circ} \mathrm{C}$ & 25.53 & 0.57 & 23.71 & 27.20 \\
\hline Relative humidity & $\%$ & 67.1 & 5.0 & 52.6 & 82.8 \\
\hline Barometric pressure & mbar & 1015.8 & 1.4 & 1012.0 & 1019.4 \\
\hline East wind & $\mathrm{m} \mathrm{s}^{-1}$ & -4.48 & 2.01 & -8.34 & 4.09 \\
\hline North wind & $\mathrm{m} \mathrm{s}^{-1}$ & -4.31 & 2.01 & -9.55 & 2.23 \\
\hline Wind speed ${ }^{a}$ & $\mathrm{~m} \mathrm{~s}^{-1}$ & 6.64 & 1.63 & 1.81 & 10.78 \\
\hline Wind direction ${ }^{\mathrm{b}}$ & $\circ$ & 227 & & & \\
\hline Wind speed ${ }^{c}$ & $\mathrm{~m} \mathrm{~s}^{-1}$ & 6.22 & & & \\
\hline Wind direction ${ }^{\mathrm{d}}$ & $\circ$ & 226 & & & \\
\hline Incoming short-wave radiation & $\mathrm{W} \mathrm{m}^{-2}$ & 221.9 & 305.7 & 0.0 & 1003.3 \\
\hline Incoming long-wave radiation & $\mathrm{W} \mathrm{m}^{-2}$ & 377.0 & 13.5 & 345.6 & 431.4 \\
\hline Sea surface temperature & ${ }^{\circ} \mathrm{C}$ & 26.34 & 0.25 & 25.66 & 26.94 \\
\hline Specific humidity & $\mathrm{g} \mathrm{kg}^{-1}$. & 13.59 & 1.19 & 9.77 & 16.39 \\
\hline Precipitation rate & $\mathrm{mm} \mathrm{hr} r^{-1}$ & 0.0005 & 0.0360 & 0.0000 & 2.7786 \\
\hline Evaporation rate & $\mathrm{mm} \mathrm{hr}^{-1}$ & 0.2890 & 0.0772 & 0.0744 & 0.5516 \\
\hline Evaporation rate - precipitation rate & $\mathrm{mm} \mathrm{hr}^{-1}$ & 0.2886 & 0.0855 & -2.5433 & 0.5516 \\
\hline Wind stress & $\mathrm{N} \mathrm{m}^{-2}$ & 0.0860 & 0.0442 & 0.0048 & 0.2464 \\
\hline Sensible heat flux & $\mathrm{W} \mathrm{m} \mathrm{m}^{-2}$ & -5.7 & 5.0 & -23.7 & 6.1 \\
\hline Latent heat flux & $\mathrm{W} \mathrm{m^{-2 }}$ & -196.9 & 52.6 & -375.8 & -50.7 \\
\hline Net short-wave radiation & $\mathrm{W} \mathrm{m} \mathrm{m}^{-2}$ & 206.7 & 291.7 & 0.0 & 961.8 \\
\hline Net long-wave radiation & $\mathrm{W} \mathrm{m} \mathrm{m}^{-2}$ & -75.1 & 12.6 & -102.8 & -22.4 \\
\hline Net heat flux & $\mathrm{W} \mathrm{m} \mathrm{m}^{-2}$ & -71.0 & 301.3 & -498.0 & 760.6 \\
\hline Skin temperature $\mathrm{f}^{\mathrm{f}}$ & ${ }^{\circ} \mathrm{C}$ & 26.04 & 0.27 & 25.34 & 26.74 \\
\hline $10 \mathrm{~m}$ wind speed ${ }^{\mathrm{g}}$ & $\mathrm{m} \mathrm{s}^{-1}$ & 7.32 & 1.83 & 1.71 & 11.96 \\
\hline $2 \mathrm{~m}$ air temperature $\mathrm{g}$ & ${ }^{\circ} \mathrm{C}$ & 25.55 & 0.57 & 23.75 & 27.19 \\
\hline $2 \mathrm{~m}$ relative humidity $\mathrm{g}$ & $\%$ & 68.4 & 4.8 & 53.3 & 84.3 \\
\hline $2 \mathrm{~m}$ specific humidity ${ }^{\mathrm{g}}$ & $\mathrm{g} \mathrm{kg}^{-1}$ & 13.76 & 1.17 & 9.98 & 16.51 \\
\hline
\end{tabular}

${ }^{a}$ Scalar averaged

bector averaged from components of a unit vector oriented in the direction of the wind

c Vector averaged

${ }^{d}$ Computed as the arctangent of the average east and north components

${ }^{\mathrm{e}}$ Measured at $0.17 \mathrm{~m}$ depth

f The temperature of the upper few millimeters of the ocean. Computed from Fairall et al. (1996b)

${ }^{g}$ Estimated from boundary layer profiles in flux algorithm 
Table 23. Statistics of observables and fluxes for January 1995.

\begin{tabular}{|c|c|c|c|c|c|}
\hline Variable & Unit & Mean & Std. Dev. & Minimum & Maximum \\
\hline Air temperature & ${ }^{\circ} \mathrm{C}$ & 24.21 & 0.36 & 22.90 & 25.51 \\
\hline Relative humidity & $\%$ & 67.6 & 8.3 & 47.3 & 85.3 \\
\hline Barometric pressure & mbar & 1015.8 & 1.5 & 1011.8 & 1020.3 \\
\hline East wind & $\mathrm{m} \mathrm{s}^{-1}$ & -3.99 & 1.64 & -10.23 & 2.51 \\
\hline North wind & $\mathrm{m} \mathrm{s}^{-1}$ & -4.23 & 1.55 & -9.42 & 1.13 \\
\hline Wind speed ${ }^{\mathrm{a}}$ & $\mathrm{m} \mathrm{s}^{-1}$ & 6.03 & 1.58 & 0.55 & 10.89 \\
\hline Wind direction $^{\mathrm{b}}$ & $\circ$ & 223 & & & \\
\hline Wind speed $^{c}$ & $\mathrm{~m} \mathrm{~s}^{-1}$ & 5.81 & & & \\
\hline Wind direction $^{\mathrm{d}}$ & $\circ$ & 223 & & & \\
\hline Incoming short-wave radiation & $\mathrm{W} \mathrm{m}^{-2}$ & 237.0 & 323.4 & -0.1 & 1067.7 \\
\hline Incoming long-wave radiation & $\mathrm{W} \mathrm{m} \mathrm{m}^{-2}$ & 367.1 & 16.5 & 335.2 & 420.6 \\
\hline Sea surface temperature ${ }^{\mathrm{e}}$ & ${ }^{\circ} \mathrm{C}$ & 25.30 & 0.34 & 24.91 & 26.28 \\
\hline Specific humidity & $\mathrm{g} \mathrm{kg}^{-1}$ & 12.61 & 1.49 & 8.59 & 15.41 \\
\hline Precipitation rate & $\mathrm{mm} \mathrm{hr}^{-1}$ & 0.0004 & 0.0314 & 0.0000 & 2.4203 \\
\hline Evaporation rate & $\mathrm{mm} \mathrm{hr}^{-1}$ & 0.2510 & 0.0834 & 0.0642 & 0.5408 \\
\hline Evaporation rate - precipitation rate & $\mathrm{mm} \mathrm{hr}^{-1}$ & 0.2506 & 0.0894 & -2.2208 & 0.5408 \\
\hline Wind stress & $\mathrm{N} \mathrm{m}^{-2}$ & 0.0662 & 0.0393 & 0.0008 & 0.2450 \\
\hline Sensible heat flux & $\mathrm{W} \mathrm{m}^{-2}$ & -7.6 & 3.8 & -34.1 & 4.0 \\
\hline Latent heat flux & $\mathrm{W} \mathrm{m}^{-2}$ & -171.0 & 56.9 & -368.5 & -43.7 \\
\hline Net short-wave radiation & $\mathrm{W} \mathrm{m} \mathrm{m}^{-2}$ & 221.3 & 309.2 & 0.0 & 1024.2 \\
\hline Net long-wave radiation & $\mathrm{W} \mathrm{m}^{-2}$ & -78.6 & 15.8 & -107.9 & -25.4 \\
\hline Net heat flux & $\mathrm{W} \mathrm{m}^{-2}$ & -36.0 & 319.3 & -484.8 & 745.3 \\
\hline Skin temperature ${ }^{f}$ & ${ }^{\circ} \mathrm{C}$ & 25.00 & 0.31 & 24.52 & 25.98 \\
\hline $10 \mathrm{~m}$ wind speed $\mathrm{d}^{\mathrm{g}}$ & $\mathrm{m} \mathrm{s}^{-1}$ & 6.43 & 1.76 & 0.50 & 11.86 \\
\hline $2 \mathrm{~m}$ air temperature $\mathrm{g}^{\mathrm{g}}$ & ${ }^{\circ} \mathrm{C}$ & 24.24 & 0.36 & 22.96 & 25.52 \\
\hline $2 \mathrm{~m}$ relative humidity $\mathrm{g}$ & $\%$ & 68.8 & 8.2 & 48.1 & 88.0 \\
\hline $2 \mathrm{~m}$ specific humidity ${ }^{\mathrm{g}}$ & $\mathrm{g} \mathrm{kg}^{-1}$ & 12.76 & 1.46 & 8.78 & 15.51 \\
\hline $\begin{array}{l}\text { a Scalar averaged } \\
\text { b Vector averaged from component } \\
\text { c Vector averaged } \\
\text { d Computed as the arctangent of the } \\
\text { e Measured at } 0.17 \mathrm{~m} \text { depth } \\
\text { f The temperature of the upper few }\end{array}$ & unit ve & $\begin{array}{l}\text { riented in } \\
\text { north com } \\
\text { ocean. C }\end{array}$ & irection of & wind & \\
\hline
\end{tabular}


Table 24. Statistics of observables and fluxes for February 1995.

\begin{tabular}{|c|c|c|c|c|c|}
\hline Variable & Unit & Mean & Std. Dev. & Minimum & Maximum \\
\hline Air temperature & ${ }^{\circ} \mathrm{C}$ & 24.19 & 0.51 & 22.60 & 27.47 \\
\hline Relative humidity & $\%$ & 69.9 & 6.2 & 49.5 & 86.8 \\
\hline Barometric pressure & mbar & 1014.1 & 1.5 & 1009.9 & 1018.2 \\
\hline East wind & $\mathrm{m} \mathrm{s}^{-1}$ & -2.28 & 2.04 & -6.59 & 3.18 \\
\hline North wind & $\mathrm{m} \mathrm{s}^{-1}$ & -2.23 & 1.90 & -7.61 & 3.77 \\
\hline Wind speed ${ }^{\mathrm{a}}$ & $\mathrm{m} \mathrm{s}^{-1}$ & 3.95 & 1.53 & 0.06 & 7.74 \\
\hline Wind direction ${ }^{\mathrm{b}}$ & $\circ$ & 227 & & & \\
\hline Wind speed ${ }^{\mathrm{c}}$ & $\mathrm{m} \mathrm{s}^{-1}$ & 3.19 & & & \\
\hline Wind direction $^{\mathrm{d}}$ & $\circ$ & 226 & & & \\
\hline Incoming short-wave radiation & $\mathrm{W} \mathrm{m}^{-2}$ & 270.5 & 358.3 & 0.0 & 1214.7 \\
\hline Incoming long-wave radiation & $\mathrm{W} \mathrm{m}^{-2}$ & 367.2 & 12.9 & 336.3 & 423.7 \\
\hline Sea surface temperature ${ }^{e}$ & ${ }^{\circ} \mathrm{C}$ & 25.35 & 0.35 & 24.89 & 27.18 \\
\hline Specific humidity & $\mathrm{g} \mathrm{kg}^{-1}$ & 13.00 & 1.32 & 8.66 & 15.87 \\
\hline Precipitation rate & $\mathrm{mm} \mathrm{hr} \mathbf{r}^{-1}$ & 0.0000 & 0.0000 & 0.0000 & 0.0000 \\
\hline Evaporation rate & $\mathrm{mm} \mathrm{hr}^{-1}$ & 0.1625 & 0.0632 & 0.0333 & 0.3512 \\
\hline Evaporation rate - precipitation rate & $\mathrm{mm} \mathrm{hr}^{-1}$ & 0.1625 & 0.0632 & 0.0333 & 0.3512 \\
\hline Wind stress & $\mathrm{N} \mathrm{m}^{-2}$ & 0.0291 & 0.0198 & 0.0001 & 0.1082 \\
\hline Sensible heat flux & $\mathrm{W} \mathrm{m}^{-2}$ & -5.4 & 3.1 & -18.4 & 3.9 \\
\hline Latent heat flux & $\mathrm{W} \mathrm{m}^{-2}$ & -110.7 & 43.1 & -239.3 & -22.7 \\
\hline Net short-wave radiation & $\mathrm{W} \mathrm{m}^{-2}$ & 254.0 & 344.2 & 0.0 & 1170.0 \\
\hline Net long-wave radiation & $\mathrm{W} \mathrm{m}^{-2}$ & -78.8 & 12.3 & -106.4 & -25.2 \\
\hline Net heat flux & $\mathrm{W} \mathrm{m}^{-2}$ & 59.1 & 348.6 & -357.1 & 1011.4 \\
\hline Skin temperature ${ }^{f}$ & ${ }^{\circ} \mathrm{C}$ & 25.06 & 0.39 & 24.52 & 26.97 \\
\hline $10 \mathrm{~m}$ wind speed ${ }^{\mathrm{g}}$ & $\mathrm{m} \mathrm{s}^{-1}$ & 4.21 & 1.67 & 0.11 & 8.46 \\
\hline $2 \mathrm{~m}$ air temperature $\mathrm{g}$ & ${ }^{\circ} \mathrm{C}$ & 24.22 & 0.50 & 22.65 & 27.43 \\
\hline $2 \mathrm{~m}$ relative humidity $\mathrm{g}$ & $\%$ & 70.7 & 6.2 & 51.5 & 87.5 \\
\hline $2 \mathrm{~m}$ specific humidity ${ }^{\mathrm{g}}$ & $\mathrm{g} \mathrm{kg}^{-1}$ & 13.13 & 1.30 & 8.84 & 15.96 \\
\hline
\end{tabular}

\footnotetext{
${ }^{a}$ Scalar averaged

b Vector averaged from components of a unit vector oriented in the direction of the wind

${ }^{c}$ Vector averaged

Computed as the arctangent of the average east and north components

' Measured at $0.17 \mathrm{~m}$ depth

${ }^{f}$ The temperature of the upper few millimeters of the ocean. Computed from Fairall et al. (1996b)

$\mathrm{g}$ Estimated from boundary layer profiles in flux algorithm
} 
Table 25. Statistics of observables and fluxes for March 1995.

\begin{tabular}{|c|c|c|c|c|c|}
\hline Variable & Unit & Mean & Std. Dev. & Minimum & Maximum \\
\hline Air temperature & ${ }^{\circ} \mathrm{C}$ & 25.30 & 0.68 & 23.82 & 28.69 \\
\hline Relative humidity & $\%$ & 73.2 & 6.6 & 52.0 & 89.1 \\
\hline Barometric pressure & mbar & 1013.2 & 2.1 & 1008.1 & 1017.7 \\
\hline East wind & $\mathrm{m} \mathrm{s}^{-1}$ & -2.27 & 2.84 & -9.33 & 5.03 \\
\hline North wind & $\mathrm{m} \mathrm{s}^{-1}$ & -1.92 & 2.12 & -8.04 & 5.86 \\
\hline Wind speed ${ }^{\mathrm{a}}$ & $\mathrm{m} \mathrm{s}^{-1}$ & 4.26 & 1.80 & 0.04 & 9.53 \\
\hline Wind direction ${ }^{\mathrm{b}}$ & $\circ$ & 226 & & & \\
\hline Wind speed ${ }^{c}$ & $\mathrm{~m} \mathrm{~s}^{-1}$ & 2.97 & & & \\
\hline Wind direction $^{\mathrm{d}}$ & $\circ$ & 230 & & & \\
\hline Incoming short-wave radiation & $W \mathrm{~m}^{-2}$ & 300.6 & 386.6 & 0.0 & 1169.2 \\
\hline Incoming long-wave radiation & $W \mathrm{~m}^{-2}$ & 372.9 & 14.6 & 338.9 & 427.3 \\
\hline Sea surface temperature ${ }^{\mathrm{e}}$ & ${ }^{\circ} \mathrm{C}$ & 26.25 & 0.76 & 25.24 & 28.78 \\
\hline Specific humidity & $\mathrm{g} \mathrm{kg}^{-1}$ & 14.47 & 1.46 & 10.20 & 17.72 \\
\hline Precipitation rate & $\mathrm{mm} \mathrm{hr} r^{-1}$ & 0.0000 & 0.0000 & 0.0000 & 0.0000 \\
\hline Evaporation rate & $\mathrm{mm} \mathrm{hr}{ }^{-1}$ & 0.1646 & 0.0756 & 0.0221 & 0.4214 \\
\hline Evaporation rate - precipitation rate & $\mathrm{mm} \mathrm{hr}^{-1}$ & 0.1646 & 0.0756 & 0.0221 & 0.4214 \\
\hline Wind stress & $\mathrm{N} \mathrm{m}^{-2}$ & 0.0354 & 0.0278 & 0.0001 & 0.1742 \\
\hline Sensible heat flux & $\mathrm{W} \mathrm{m} \mathrm{m}^{-2}$ & -4.2 & 3.0 & -15.4 & 3.5 \\
\hline Latent heat flux & $\mathrm{W} \mathrm{m}^{-2}$ & -112.1 & 51.5 & -287.2 & -15.0 \\
\hline Net short-wave radiation & $\mathrm{W} \mathrm{m}^{-2}$ & 283.9 & 372.8 & 0.0 & 1129.0 \\
\hline Net long-wave radiation & $\mathrm{W} \mathrm{m}^{-2}$ & -78.7 & 15.0 & -109.6 & -23.5 \\
\hline Net heat flux & $\mathrm{W} \mathrm{m} \mathrm{m}^{-2}$ & 88.8 & 375.7 & -386.1 & 952.2 \\
\hline Skin temperature ${ }^{\mathrm{f}}$ & ${ }^{\circ} \mathrm{C}$ & 25.98 & 0.79 & 24.88 & 29.13 \\
\hline $10 \mathrm{~m}$ wind speed $\mathrm{d}^{\mathrm{g}}$ & $\mathrm{m} \mathrm{s}^{-1}$ & 4.57 & 1.99 & 0.11 & 10.45 \\
\hline $2 \mathrm{~m}$ air temperature ${ }^{\mathrm{g}}$ & ${ }^{\circ} \mathrm{C}$ & 25.32 & 0.68 & 23.85 & 28.69 \\
\hline $2 \mathrm{~m}$ relative humidity $\mathrm{g}$ & $\%$ & 73.5 & 6.5 & 52.7 & 88.4 \\
\hline 2m specific humidity & $\mathrm{g} \mathrm{kg}^{-1}$ & 14.60 & 1.43 & 10.44 & 17.80 \\
\hline $\begin{array}{l}\text { a Scalar averaged } \\
\text { b Vector averaged from component } \\
\text { c Vector averaged } \\
\text { d Computed as the arctangent of the } \\
\text { e Measured at } 0.17 \mathrm{~m} \text { depth } \\
\text { f The temperature of the upper few } \\
\text { g Estimated from houndary laver }\end{array}$ & f a unit ver & oriented in th & $\begin{array}{l}\text { direction of } \\
\text { ents }\end{array}$ & wind & \\
\hline
\end{tabular}


Table 26. Statistics of observables and fluxes for April 1995.

\begin{tabular}{|c|c|c|c|c|c|}
\hline Variable & Unit & Mean & Std. Dev. & Minimum & Maximum \\
\hline Air temperature & ${ }^{\circ} \mathrm{C}$ & 27.19 & 1.00 & 25.05 & 31.47 \\
\hline Relative humidity & $\%$ & 74.0 & 5.8 & 52.7 & 83.8 \\
\hline Barometric pressure & mbar & 1011.2 & 1.5 & 1007.4 & 1015.6 \\
\hline East wind & $\mathrm{m} \mathrm{s}^{-1}$ & -1.17 & 2.26 & -7.33 & 4.55 \\
\hline North wind & $\mathrm{m} \mathrm{s}^{-1}$ & -1.17 & 2.06 & -6.77 & 5.40 \\
\hline Wind speed ${ }^{\mathrm{a}}$ & $\mathrm{m} \mathrm{s}^{-1}$ & 3.17 & 1.42 & 0.09 & 7.89 \\
\hline Wind direction ${ }^{\mathrm{b}}$ & $\circ$ & 226 & & & \\
\hline Wind speed ${ }^{c}$ & $\mathrm{~m} \mathrm{~s}^{-1}$ & 1.65 & & & \\
\hline Wind direction & $\circ$ & 225 & & & \\
\hline Incoming short-wave radiation & $\mathrm{W} \mathrm{m} \mathrm{m}^{-2}$ & 318.9 & 400.0 & -0.3 & 1148.6 \\
\hline Incoming long-wave radiation & $\mathrm{W} \mathrm{m} \mathrm{m}^{-2}$ & 383.2 & 13.3 & 359.4 & 442.7 \\
\hline Sea surface temperature & ${ }^{\circ} \mathrm{C}$ & 28.47 & 0.90 & 27.11 & 31.85 \\
\hline Specific humidity & $\mathrm{g} \mathrm{kg}^{-1}$ & 16.46 & 1.83 & 10.48 & 20.55 \\
\hline Precipitation rate & $\mathrm{mm} \mathrm{hr}^{-1}$ & 0.0000 & 0.0000 & 0.0000 & 0.0000 \\
\hline Evaporation rate & $\mathrm{mm} \mathrm{hr}^{-1}$ & 0.1435 & 0.0626 & 0.0264 & 0.4922 \\
\hline Evaporation rate - precipitation rate & $\mathrm{mm} \mathrm{hr}^{-1}$ & 0.1435 & 0.0626 & 0.0264 & 0.4922 \\
\hline Wind stress & $\mathrm{N} \mathrm{m}^{-2}$ & 0.0191 & 0.0150 & 0.0001 & 0.1153 \\
\hline Sensible heat flux & $\mathrm{W} \mathrm{m}^{-2}$ & -5.0 & 2.9 & -14.2 & 2.9 \\
\hline Latent heat flux & $\mathrm{W} \mathrm{m}^{-2}$ & -97.8 & 42.6 & -335.4 & -18.0 \\
\hline Net short-wave radiation & $\mathrm{W} \mathrm{m}^{-2}$ & 301.9 & 386.4 & -0.1 & 1111.0 \\
\hline Net long-wave radiation & $\mathrm{W} \mathrm{m}^{-2}$ & -81.8 & 9.9 & -108.5 & -27.8 \\
\hline Net heat flux & $\mathrm{W} \mathrm{m} \mathrm{m}^{-2}$ & 117.3 & 386.5 & -414.0 & 939.9 \\
\hline Skin temperature $\mathrm{f}^{\mathrm{f}}$ & ${ }^{\circ} \mathrm{C}$ & 28.18 & 0.97 & 26.69 & 31.86 \\
\hline $10 \mathrm{~m}$ wind speed ${ }^{\mathrm{g}}$ & $\mathrm{m} \mathrm{s}^{-1}$ & 3.35 & 1.54 & 0.13 & 8.61 \\
\hline $2 \mathrm{~m}$ air temperature ${ }^{\mathrm{g}}$ & ${ }^{\circ} \mathrm{C}$ & 27.22 & 0.99 & 25.08 & 31.47 \\
\hline $2 \mathrm{~m}$ relative humidity & $\%$ & 74.3 & 6.1 & 52.5 & 84.1 \\
\hline $2 \mathrm{~m}$ specific humidityg & $\mathrm{g} \mathrm{kg}^{-1}$ & 16.60 & 1.82 & 10.70 & 20.68 \\
\hline
\end{tabular}

a Scalar averaged

b Vector averaged from components of a unit vector oriented in the direction of the wind

c Vector averaged

Computed as the arctangent of the average east and north components

e Measured at $0.17 \mathrm{~m}$ depth

f The temperature of the upper few millimeters of the ocean. Computed from Fairall et al. (1996b)

g Estimated from boundary layer profiles in flux algorithm 
Table 27. Statistics of observables and fluxes for May 1995.

\begin{tabular}{|c|c|c|c|c|c|}
\hline Variable & Unit & Mean & Std. Dev. & Minimum & Maximum \\
\hline Air temperature & ${ }^{\circ} \mathrm{C}$ & 28.86 & 0.48 & 27.41 & 31.39 \\
\hline Relative humidity & $\%$ & 75.9 & 5.8 & 60.8 & 88.1 \\
\hline Barometric pressure & mbar & 1008.7 & 1.7 & 1003.9 & 1012.7 \\
\hline East wind. & $\mathrm{m} \mathrm{s}^{-1}$ & 3.06 & 3.23 & -3.25 & 9.60 \\
\hline North wind & $\mathrm{m} \mathrm{s}^{-1}$ & 0.05 & 2.46 & -5.88 & 6.94 \\
\hline Wind speed ${ }^{a}$ & $\mathrm{~m} \mathrm{~s}^{-1}$ & 4.46 & 2.43 & 0.04 & 10.50 \\
\hline Wind direction ${ }^{\mathrm{b}}$ & $\circ$ & 103 & & & \\
\hline Wind speed ${ }^{\mathrm{c}}$ & $\mathrm{m} \mathrm{s}^{-1}$ & 3.06 & & & \\
\hline Wind direction ${ }^{d}$ & $\circ$ & 89 & & & \\
\hline Incoming short-wave radiation & $\mathrm{W} \mathrm{m}^{-2}$ & 313.5 & 381.1 & -0.3 & 1067.0 \\
\hline Incoming long-wave radiation & $\mathrm{W} \mathrm{m}^{-2}$ & 406.7 & 14.3 & 373.3 & 458.2 \\
\hline Sea surface temperature ${ }^{e}$ & ${ }^{\circ} \mathrm{C}$ & 29.84 & 0.51 & 29.21 & 32.23 \\
\hline Specific humidity & $\mathrm{g} \mathrm{kg}^{-1}$ & 18.73 & 1.64 & 14.46 & 22.35 \\
\hline Precipitation rate & $\mathrm{mm} \mathrm{hr} \mathbf{r}^{-1}$ & 0.0000 & 0.0000 & 0.0000 & 0.0000 \\
\hline Evaporation rate & $\mathrm{mm} \mathrm{hr} r^{-1}$ & 0.1686 & 0.0547 & 0.0268 & 0.3466 \\
\hline Evaporation rate - precipitation rate & $\mathrm{mm} \mathrm{hr^{-1 }}$ & 0.1686 & 0.0547 & 0.0268 & 0.3466 \\
\hline Wind stress & $\mathrm{N} \mathrm{m}^{-2}$ & 0.0436 & 0.0428 & 0.0001 & 0.2182 \\
\hline Sensible heat flux & $\mathrm{W} \mathrm{m}^{-2}$ & -3.7 & 3.2 & -16.4 & 5.5 \\
\hline Latent heat flux & $\mathrm{W} \mathrm{m}^{-2}$ & -114.9 & 37.3 & -236.2 & -18.3 \\
\hline Net short-wave radiation & $\mathrm{W} \mathrm{m}^{-2}$ & 297.0 & 368.4 & -0.1 & 1032.4 \\
\hline Net long-wave radiation & $\mathrm{W} \mathrm{m}^{-2}$ & -67.4 & 13.6 & -99.6 & -15.4 \\
\hline Net heat flux & $\mathrm{W} \mathrm{m}^{-2}$ & 111.0 & 365.9 & -309.3 & 872.2 \\
\hline Skin temperature ${ }^{f}$ & ${ }^{\circ} \mathrm{C}$ & 29.58 & 0.51 & 28.87 & 32.17 \\
\hline $10 \mathrm{~m}$ wind speed ${ }^{\mathrm{g}}$ & $\mathrm{m} \mathrm{s}^{-1}$ & 4.80 & 2.70 & 0.09 & 11.60 \\
\hline $2 \mathrm{~m}$ air temperature $\mathrm{g}$ & ${ }^{\circ} \mathrm{C}$ & 28.88 & 0.48 & 27.46 & 31.34 \\
\hline $2 \mathrm{~m}$ relative humidity $\mathrm{g}$ & $\%$ & 76.6 & 5.8 & 61.2 & 88.4 \\
\hline 2m specific humidity $\mathrm{g}$ & $\mathrm{g} \mathrm{kg}^{-1}$ & 18.88 & 1.62 & 14.70 & 22.44 \\
\hline $\begin{array}{l}\text { a Scalar averaged } \\
\text { b Vector averaged from component } \\
\text { c Vector averaged } \\
\text { d Computed as the arctangent of th } \\
\text { e Measured at } 0.17 \mathrm{~m} \text { depth } \\
\text { f The temperature of the upper few } \\
\text { g Estimated from houndary laver }\end{array}$ & $\begin{array}{l}\text { a unit vec } \\
\text { erage east } \\
\text { llimeters } \\
\text { les in flux }\end{array}$ & $\begin{array}{l}\text { oriented in } \\
\text { north com } \\
\text { e ocean. C }\end{array}$ & $\begin{array}{l}\text { direction o } \\
\text { ents }\end{array}$ & wind & \\
\hline
\end{tabular}


Table 28. Statistics of observables and fluxes for June 1995.

\begin{tabular}{|c|c|c|c|c|c|}
\hline Variable & Unit & Mean & Std. Dev. & Minimum & Maximum \\
\hline Air temperature & ${ }^{\circ} \mathrm{C}$ & 29.25 & 0.69 & 28.07 & 30.56 \\
\hline Relative humidity & $\%$ & 82.3 & 2.1 & 70.8 & 88.4 \\
\hline Barometric pressure & mbar & 1005.2 & 2.1 & 999.3 & 1010.8 \\
\hline East wind & $\mathrm{m} \mathrm{s}^{-1}$ & 8.74 & 2.44 & 0.92 & 13.77 \\
\hline North wind & $\mathrm{m} \mathrm{s}^{-1}$ & 4.35 & 2.25 & -3.22 & 8.69 \\
\hline Wind speed ${ }^{2}$ & $\mathrm{~m} \mathrm{~s}^{-1}$ & 9.91 & 2.85 & 1.38 & 15.23 \\
\hline Wind direction ${ }^{\mathrm{b}}$ & $\circ$ & 66 & & & \\
\hline Wind speed ${ }^{c}$ & $\mathrm{~m} \mathrm{~s}^{-1}$ & 9.76 & & & \\
\hline Wind direction ${ }^{d}$ & $\circ$ & 64 & & & \\
\hline Incoming short-wave radiation & $\mathrm{W} \mathrm{m}^{-2}$ & 264.8 & 330.2 & -0.3 & 1030.4 \\
\hline Incoming long-wave radiation & $\mathrm{W} \mathrm{m} \mathrm{m}^{-2}$ & 436.4 & 10.1 & 412.6 & 506.5 \\
\hline Sea surface temperature ${ }^{e}$ & ${ }^{\circ} \mathrm{C}$ & 29.45 & 0.73 & 28.57 & 31.22 \\
\hline Specific humidity & $\mathrm{g} \mathrm{kg}^{-1}$ & 20.69 & 0.73 & 18.74 & 22.64 \\
\hline Precipitation rate & $\mathrm{mm} \mathrm{hr} \mathbf{r}^{-1}$ & 0.0008 & 0.0600 & 0.0000 & 4.5548 \\
\hline Evaporation rate & $\mathrm{mm} \mathrm{hr}^{-1}$ & 0.2429 & 0.0540 & 0.0712 & 0.4073 \\
\hline Evaporation rate - precipitation rate & $\mathrm{mm} \mathrm{hr}^{-1}$ & 0.2421 & 0.0807 & -4.3108 & 0.4073 \\
\hline Wind stress & $\mathrm{N} \mathrm{m}^{-2}$ & 0.2123 & 0.1163 & 0.0037 & 0.5427 \\
\hline Sensible heat flux & $\mathrm{W} \mathbf{m}^{-2}$ & 0.1 & 3.0 & -16.8 & 10.0 \\
\hline Latent heat flux & $\mathrm{W} \mathrm{m}^{-2}$ & -165.5 & 36.8 & -277.6 & -48.5 \\
\hline Net short-wave radiation & $W m^{-2}$ & 251.0 & 319.2 & -0.1 & 997.0 \\
\hline Net long-wave radiation & $\mathrm{W} \mathrm{m}^{-2}$ & -37.0 & 11.7 & -64.6 & 26.8 \\
\hline Net heat flux & $\mathrm{W} \mathrm{m}^{-2}$ & 48.7 & 322.8 & -318.1 & 833.3 \\
\hline Skin temperature ${ }^{f}$ & ${ }^{\circ} \mathrm{C}$ & 29.31 & 0.70 & 28.43 & 31.11 \\
\hline $10 \mathrm{~m}$ wind speed $\mathrm{d}^{\mathrm{g}}$ & $\mathrm{m} \mathrm{s}^{-1}$ & 10.86 & 3.21 & 1.46 & 16.89 \\
\hline $2 \mathrm{~m}$ air temperature $\mathrm{g}$ & ${ }^{\circ} \mathrm{C}$ & 29.26 & 0.68 & 28.08 & 30.56 \\
\hline $2 \mathrm{~m}$ relative humidity ${ }^{\mathrm{g}}$ & $\%$ & 82.4 & 1.9 & 72.1 & 87.4 \\
\hline $2 \mathrm{~m}$ specific humidity & $\mathrm{g} \mathrm{kg}^{-1}$ & 20.81 & 0.74 & 18.89 & 22.74 \\
\hline
\end{tabular}

${ }^{a}$ Scalar averaged

${ }^{b}$ Vector averaged from components of a unit vector oriented in the direction of the wind

${ }^{c}$ Vector averaged

${ }^{d}$ Computed as the arctangent of the average east and north components

e Measured at $0.17 \mathrm{~m}$ depth

${ }^{f}$ The temperature of the upper few millimeters of the ocean. Computed from Fairall et al. (1996b)

${ }^{\mathrm{g}}$ Estimated from boundary layer profiles in flux algorithm 
Table 29. Statistics of observables and fluxes for July 1995.

\begin{tabular}{|c|c|c|c|c|c|}
\hline Variable & Unit & Mean & Std. Dev. & Minimum & Maximum \\
\hline Air temperature & ${ }^{\circ} \mathrm{C}$ & 27.42 & 0.80 & 25.83 & 28.78 \\
\hline Relative humidity & $\%$ & 86.3 & 2.3 & 80.7 & 93.9 \\
\hline Barometric pressure & mbar & 1002.5 & 2.3 & 997.0 & 1007.9 \\
\hline East wind & $\mathrm{m} \mathrm{s}^{-1}$ & 10.01 & 1.63 & 5.47 & 14.82 \\
\hline North wind & $\mathrm{m} \mathrm{s}^{-1}$ & 7.18 & 1.47 & 1.87 & 13.65 \\
\hline Wind speed ${ }^{\mathrm{a}}$ & $\mathrm{m} \mathrm{s}^{-1}$ & 12.37 & 1.89 & 6.50 & 18.34 \\
\hline Wind direction ${ }^{\mathrm{b}}$ & $\circ$ & 54 & & & \\
\hline Wind speed ${ }^{c}$ & $\mathrm{~m} \mathrm{~s}^{-1}$ & 12.32 & & & \\
\hline Wind direction ${ }^{\mathrm{d}}$ & $\circ$ & 54 & & & \\
\hline Incoming short-wave radiation & $\mathrm{W} \mathrm{m} \mathrm{m}^{-2}$ & 198.1 & 267.9 & -0.5 & 988.9 \\
\hline Incoming long-wave radiation & $W m^{-2}$ & 440.6 & 11.1 & 411.3 & 479.5 \\
\hline Sea surface temperature ${ }^{e}$ & ${ }^{\circ} \mathrm{C}$ & 27.00 & 1.10 & 24.95 & 28.59 \\
\hline Specific humidity & $\mathrm{g} \mathrm{kg}^{-1}$ & 19.37 & 0.58 & 18.08 & 20.76 \\
\hline Precipitation rate & $\mathrm{mm} \mathrm{hr} \mathrm{r}^{-1}$ & 0.0004 & 0.0278 & 0.0000 & 2.1422 \\
\hline Evaporation rate & $\mathrm{mm} \mathrm{hr}^{-1}$ & 0.1796 & 0.0703 & 0.0281 & 0.3430 \\
\hline Evaporation rate - precipitation rate & $m m h^{-1}$ & 0.1792 & 0.0753 & -1.8992 & 0.3430 \\
\hline Wind stress & $\mathrm{N} \mathrm{m}^{-2}$ & 0.3248 & 0.1215 & 0.0567 & 0.8332 \\
\hline Sensible heat flux & $\mathrm{W} \mathrm{m}^{-2}$ & 9.0 & 5.1 & -7.3 & 22.1 \\
\hline Latent heat flux & $\mathrm{W} \mathrm{m}^{-2}$ & -122.4 & 47.9 & -233.7 & -19.2 \\
\hline Net short-wave radiation & $\mathrm{W} \mathrm{\textrm {m } ^ { - 2 }}$ & 188.0 & 258.7 & -0.1 & 956.5 \\
\hline Net long-wave radiation & $\mathrm{W} \mathrm{m}^{-2}$ & -18.6 & 9.6 & -50.5 & 15.6 \\
\hline Net heat flux & $\mathbf{W} \mathrm{m}^{-2}$ & 56.0 & 268.7 & -280.4 & 850.6 \\
\hline Skin temperature $\mathrm{f}^{\mathrm{f}}$ & ${ }^{\circ} \mathrm{C}$ & 26.93 & 1.07 & 24.91 & 28.52 \\
\hline $10 \mathrm{~m}$ wind speed ${ }^{\mathrm{g}}$ & $\mathrm{m} \mathrm{s}^{-1}$ & 13.50 & 2.16 & 6.76 & 20.07 \\
\hline $2 \mathrm{~m}$ air temperature $\mathrm{g}$ & ${ }^{\circ} \mathrm{C}$ & 27.42 & 0.81 & 25.82 & 28.78 \\
\hline $2 \mathrm{~m}$ relative humidity $\mathrm{g}$ & $\%$ & 85.7 & 2.2 & 79.5 & 91.8 \\
\hline $2 \mathrm{~m}$ specific humidity ${ }^{\mathrm{g}}$ & $\mathrm{g} \mathrm{kg}^{-1}$ & 19.43 & 0.59 & 18.12 & 20.84 \\
\hline
\end{tabular}

${ }^{a}$ Scalar averaged

${ }^{b}$ Vector averaged from components of a unit vector oriented in the direction of the wind

- Vector averaged

${ }^{d}$ Computed as the arctangent of the average east and north components

e Measured at $0.17 \mathrm{~m}$ depth

${ }^{f}$ The temperature of the upper few millimeters of the ocean. Computed from Fairall et al. (1996b)

${ }^{\mathrm{g}}$ Estimated from boundary layer profiles in flux algorithm 
Table 30. Statistics of observables and fluxes for August 1995.

\begin{tabular}{|c|c|c|c|c|c|}
\hline Variable & Unit & Mean & Std. Dev. & Minimum & Maximum \\
\hline Air temperature & ${ }^{\circ} \mathrm{C}$ & 26.46 & 0.26 & 25.07 & 27.03 \\
\hline Relative humidity & $\%$ & 89.6 & 1.5 & 84.6 & 94.6 \\
\hline Barometric pressure & mbar & 1006.2 & 2.0 & 1001.7 & 1011.5 \\
\hline East wind & $\mathrm{m} \mathrm{s}^{-1}$ & 7.16 & 1.62 & 2.96 & 11.93 \\
\hline North wind & $\mathrm{m} \mathrm{s}^{-1}$ & 5.88 & 0.81 & 3.12 & 9.06 \\
\hline Wind speed $^{\mathbf{a}}$ & $\mathrm{m} \mathrm{s}^{-1}$ & 9.33 & 1.47 & 4.53 & 13.32 \\
\hline Wind direction ${ }^{\mathrm{b}}$ & $\circ$ & 50 & & & \\
\hline Wind speed $^{c}$ & $\mathrm{~m} \mathrm{~s}^{-1}$ & 9.27 & & & \\
\hline Wind direction $^{\mathrm{d}}$ & $\circ$ & 51 & & & \\
\hline Incoming short-wave radiation & $\mathrm{W} \mathrm{m} \mathrm{m}^{-2}$ & 230.2 & 306.3 & -0.7 & 994.3 \\
\hline Incoming long-wave radiation & $\mathrm{W} \mathrm{m} \mathrm{m}^{-2}$ & 432.0 & 12.1 & 402.6 & 465.9 \\
\hline Sea surface temperature ${ }^{e}$ & ${ }^{\circ} \mathrm{C}$ & 25.93 & 0.49 & 24.58 & 26.71 \\
\hline Specific humidity & $\mathrm{g} \mathrm{kg}^{-1}$ & 18.94 & 0.34 & 17.99 & 19.78 \\
\hline Precipitation rate & $\mathrm{mm} \mathrm{hr} r^{-1}$ & 0.0000 & 0.0000 & 0.0000 & 0.0000 \\
\hline Evaporation rate & $\mathrm{mm} \mathrm{hr}^{-1}$ & 0.0877 & 0.0286 & 0.0117 & 0.1951 \\
\hline Evaporation rate - precipitation rate & $\mathrm{mm} \mathrm{hr}^{-1}$ & 0.0877 & 0.0286 & 0.0117 & 0.1951 \\
\hline Wind stress & $\mathrm{N} \mathrm{m}^{-2}$ & 0.1706 & 0.0608 & 0.0353 & 0.3962 \\
\hline Sensible heat flux & $\mathrm{W} \mathrm{m}^{-2}$ & 8.9 & 5.2 & -21.1 & 25.9 \\
\hline Latent heat flux & $\mathrm{W} \mathrm{m}^{-2}$ & -59.8 & 19.5 & -132.9 & -7.9 \\
\hline Net short-wave radiation & $\mathrm{W} \mathrm{m} \mathrm{m}^{-2}$ & 218.8 & 295.8 & -0.2 & 962.1 \\
\hline Net long-wave radiation & $\mathrm{W} \mathrm{m} \mathrm{m}^{-2}$ & -20.8 & 11.5 & -52.2 & 10.0 \\
\hline Net heat flux & $W \mathrm{~m}^{-2}$ & 147.0 & 295.7 & -167.9 & 880.2 \\
\hline Skin temperature $\mathrm{f}^{\mathrm{f}}$ & ${ }^{\circ} \mathrm{C}$ & 25.89 & 0.48 & 24.58 & 26.67 \\
\hline $10 \mathrm{~m}$ wind speed ${ }^{\mathrm{g}}$ & $\mathrm{m} \mathrm{s}^{-1}$ & 10.40 & 1.59 & 5.41 & 14.91 \\
\hline $2 \mathrm{~m}$ air temperature $\mathrm{g}$ & ${ }^{\circ} \mathrm{C}$ & 26.45 & 0.27 & 25.11 & 27.02 \\
\hline $2 \mathrm{~m}$ relative humidityg & $\%$ & 89.0 & 1.3 & 84.1 & 92.8 \\
\hline $2 \mathrm{~m}$ specific humidity & $\mathrm{g} \mathrm{kg}^{-1}$ & 18.98 & 0.34 & 18.03 & 19.82 \\
\hline
\end{tabular}

${ }^{a}$ Scalar averaged

${ }^{b}$ Vector averaged from components of a unit vector oriented in the direction of the wind

${ }^{c}$ Vector averaged

${ }^{d}$ Computed as the arctangent of the average east and north components

e Measured at $0.17 \mathrm{~m}$ depth

${ }^{f}$ The temperature of the upper few millimeters of the ocean. Computed from Fairall et al. (1996b)

g Estimated from boundary layer profiles in flux algorithm 
Table 31. Statistics of observables and fluxes for September 1995.

\begin{tabular}{|c|c|c|c|c|c|}
\hline Variable & Unit & Mean & Std. Dev. & Minimum & Maximum \\
\hline Air temperature & ${ }^{\circ} \mathrm{C}$ & 26.77 & 0.38 & 23.53 & 27.59 \\
\hline Relative humidity & $\%$ & 87.5 & 2.3 & 77.3 & 94.3 \\
\hline Barometric pressure & mbar & 1009.4 & 2.3 & 1002.4 & 1014.6 \\
\hline East wind & $\mathrm{m} \mathrm{s}^{-1}$ & 6.03 & 2.24 & -1.08 & 11.94 \\
\hline North wind & $\mathrm{m} \mathrm{s}^{-1}$ & 2.83 & 1.95 & -4.43 & 8.96 \\
\hline Wind speed ${ }^{\mathrm{a}}$ & $\mathrm{m} \mathrm{s}^{-1}$ & 6.82 & 2.58 & 0.28 & 13.95 \\
\hline Wind direction ${ }^{b}$ & $\circ$ & 66 & & & \\
\hline Wind speed ${ }^{\mathrm{c}}$ & $\mathrm{m} \mathrm{s}^{-1}$ & 6.66 & & & \\
\hline Wind direction ${ }^{\mathrm{d}}$ & $\circ$ & 65 & & & \\
\hline Incoming short-wave radiation & $W \mathrm{~m}^{-2}$ & 255.6 & 335.8 & -0.4 & 1068.3 \\
\hline Incoming long-wave radiation & $\mathrm{W} \mathrm{m} \mathrm{m}^{-2}$ & 421.6 & 18.4 & 386.9 & 481.6 \\
\hline Sea surface temperature & ${ }^{\circ} \mathrm{C}$ & 27.21 & 0.57 & 26.19 & 28.55 \\
\hline Specific humidity & $\mathrm{g} \mathrm{kg}^{-1}$ & 18.90 & 0.55 & 15.32 & 20.05 \\
\hline Precipitation rate & $\mathrm{mm} \mathrm{hr} r^{-1}$ & 0.0230 & 0.7059 & 0.0000 & 38.5243 \\
\hline Evaporation rate & $\mathrm{mm} \mathrm{hr}^{-1}$ & 0.1184 & 0.0275 & 0.0269 & 0.2334 \\
\hline Evaporation rate - precipitation rate & $\mathrm{mm} \mathrm{hr} \mathrm{r}^{-1}$ & 0.0954 & 0.7075 & -38.4665 & 0.2334 \\
\hline Wind stress & $\mathrm{N} \mathrm{m}^{-2}$ & 0.1008 & 0.0820 & 0.0003 & 0.4598 \\
\hline Sensible heat flux & $\mathrm{W} \mathrm{m} \mathrm{m}^{-2}$ & -1.8 & 4.7 & -34.4 & 15.7 \\
\hline Latent heat flux & $\mathrm{W} \mathrm{m}^{-2}$ & -80.7 & 18.8 & -159.1 & -18.3 \\
\hline Net short-wave radiation & $\mathrm{W} \mathrm{m}^{-2}$ & 242.1 & 323.9 & -0.1 & 1032.6 \\
\hline Net long-wave radiation & $\mathrm{W} \mathrm{m}^{-2}$ & -38.0 & 19.1 & -74.7 & 20.9 \\
\hline Net heat flux & $W \mathrm{~m}^{-2}$ & 121.6 & 319.2 & -219.4 & 957.7 \\
\hline Skin temperature ${ }^{f}$ & ${ }^{\circ} \mathrm{C}$ & 27.09 & 0.54 & 26.11 & 28.40 \\
\hline $10 \mathrm{~m}$ wind speed ${ }^{\mathrm{g}}$ & $\mathrm{m} \mathrm{s}^{-1}$ & 7.59 & 2.94 & 0.23 & 15.81 \\
\hline $2 \mathrm{~m}$ air temperature $\mathrm{g}$ & ${ }^{\circ} \mathrm{C}$ & 26.79 & 0.38 & 23.60 & 27.59 \\
\hline $2 \mathrm{~m}$ relative humidity $\mathrm{g}$ & $\%$ & 87.5 & 2.2 & 71.0 & 94.8 \\
\hline $2 \mathrm{~m}$ specific humidity ${ }^{\mathrm{g}}$ & $\mathrm{g} \mathrm{kg}^{-1}$ & 18.98 & 0.55 & 15.45 & 20.12 \\
\hline $\begin{array}{l}\text { a Scalar averaged } \\
\text { b Vector averaged from componen } \\
\text { c Vector averaged } \\
\text { d Computed as the arctangent of th } \\
\text { e Measured at } 0.17 \mathrm{~m} \text { depth } \\
\text { f The temperature of the upper few } \\
\text { g Estimated from boundary layer }\end{array}$ & $\begin{array}{l}\text { anit ve } \\
\text { rage eas }\end{array}$ & $\begin{array}{l}\text { oriented in } \\
\text { north com } \\
\text { e ocean. C } \\
\text { rithm }\end{array}$ & $\begin{array}{l}\text { lirection o } \\
\text { nts }\end{array}$ & wind & \\
\hline
\end{tabular}


Table 32. Statistics of observables and fluxes for October 1995.

\begin{tabular}{|c|c|c|c|c|c|}
\hline Variable & Unit & Mean & Std. Dev. & Minimum & Maximum \\
\hline Air temperature & ${ }^{\circ} \mathrm{C}$ & 27.26 & 0.35 & 26.36 & 29.77 \\
\hline Relative humidity & $\%$ & 80.6 & 2.3 & 72.4 & 86.6 \\
\hline Barometric pressure & mbar & 1010.4 & 1.6 & 1005.7 & 1013.7 \\
\hline East wind & $\mathrm{m} \mathrm{s}^{-1}$ & 3.13 & 1.68 & -1.64 & 7.68 \\
\hline North wind & $\mathrm{m} \mathrm{s}^{-1}$ & -0.82 & 1.94 & -4.40 & 6.25 \\
\hline Wind speed ${ }^{\mathrm{a}}$ & $\mathrm{m} \mathrm{s}^{-1}$ & 3.88 & 1.40 & 0.17 & 7.78 \\
\hline Wind direction $^{\mathrm{b}}$ & $\circ$ & 108 & & & \\
\hline Wind speed ${ }^{c}$ & $\mathrm{~m} \mathrm{~s}^{-1}$ & 3.23 & & & \\
\hline Wind direction ${ }^{d}$ & $\circ$ & 105 & & & \\
\hline Incoming short-wave radiation & $W \mathrm{~m}^{-2}$ & 259.0 & 340.7 & -0.1 & 1068.4 \\
\hline Incoming long-wave radiation & $\mathrm{W} \mathrm{m}^{-2}$ & 406.7 & 11.0 & 381.2 & 454.1 \\
\hline Sea surface temperature ${ }^{e}$ & ${ }^{\circ} \mathrm{C}$ & 28.41 & 0.28 & 28.00 & 30.26 \\
\hline Specific humidity & $\mathrm{g} \mathrm{kg}^{-1}$ & 18.16 & 0.65 & 16.89 & 19.96 \\
\hline Precipitation rate & $\mathrm{mm} \mathrm{hr}^{-1}$ & 0.0000 & 0.0000 & 0.0000 & 0.0000 \\
\hline Evaporation rate & $\mathrm{mm} \mathrm{hr}^{-1}$ & 0.1280 & 0.0415 & 0.0291 & 0.2756 \\
\hline Evaporation rate - precipitation rate & $\mathrm{mm} \mathrm{hr}^{-1}$ & 0.1280 & 0.0415 & 0.0291 & 0.2756 \\
\hline Wind stress & $\mathrm{N} \mathrm{m}^{-2}$ & 0.0266 & 0.0176 & 0.0001 & 0.1024 \\
\hline Sensible heat flux & $\mathrm{W} \mathrm{m} \mathrm{m}^{-2}$ & -5.6 & 2.1 & -13.2 & 0.0 \\
\hline Latent heat flux & $\mathrm{W} \mathrm{m} \mathrm{m}^{-2}$ & -87.2 & 28.2 & -187.8 & -19.8 \\
\hline Net short-wave radiation & $W \mathrm{~m}^{-2}$ & 244.3 & 327.9 & 0.0 & 1031.7 \\
\hline Net long-wave radiation & $\mathrm{W} \mathrm{m}^{-2}$ & -59.0 & 10.4 & -80.9 & -13.1 \\
\hline Net heat flux & $\mathrm{W} \mathrm{m} \mathrm{m}^{-2}$ & 92.4 & 326.5 & -248.2 & 895.7 \\
\hline Skin temperature ${ }^{f}$ & ${ }^{\circ} \mathrm{C}$ & 28.18 & 0.33 & 27.68 & 30.44 \\
\hline $10 \mathrm{~m}$ wind speed $\mathrm{d}^{\mathrm{g}}$ & $\mathrm{m} \mathrm{s}^{-1}$ & 4.12 & 1.51 & 0.11 & 8.27 \\
\hline $2 \mathrm{~m}$ air temperature $\mathrm{e}^{\mathrm{g}}$ & ${ }^{\circ} \mathrm{C}$ & 27.29 & 0.35 & 26.39 & 29.78 \\
\hline $2 \mathrm{~m}$ relative humidityg & $\%$ & 81.7 & 2.1 & 74.0 & 88.0 \\
\hline $2 \mathrm{~m}$ specific humidity ${ }^{\mathrm{g}}$ & $\mathrm{g} \mathrm{kg}^{-1}$ & 18.27 & 0.64 & 17.01 & 20.06 \\
\hline
\end{tabular}

\footnotetext{
${ }^{a}$ Scalar averaged

${ }^{b}$ Vector averaged from components of a unit vector oriented in the direction of the wind

${ }^{c}$ Vector averaged

${ }^{d}$ Computed as the arctangent of the average east and north components

e Measured at $0.17 \mathrm{~m}$ depth

f The temperature of the upper few millimeters of the ocean. Computed from Fairall et al. (1996b)

${ }^{\mathrm{g}}$ Estimated from boundary layer profiles in flux algorithm
} 


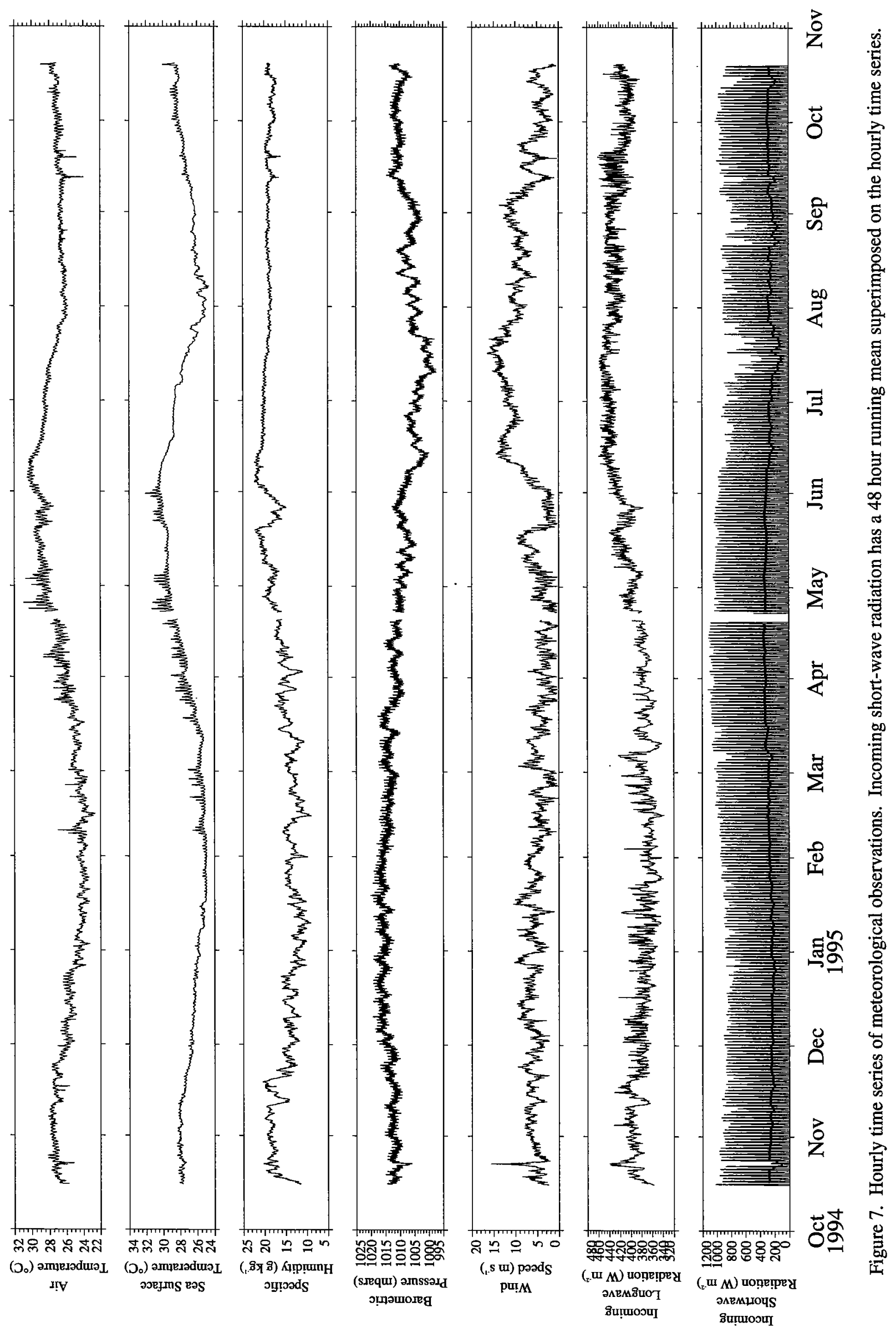




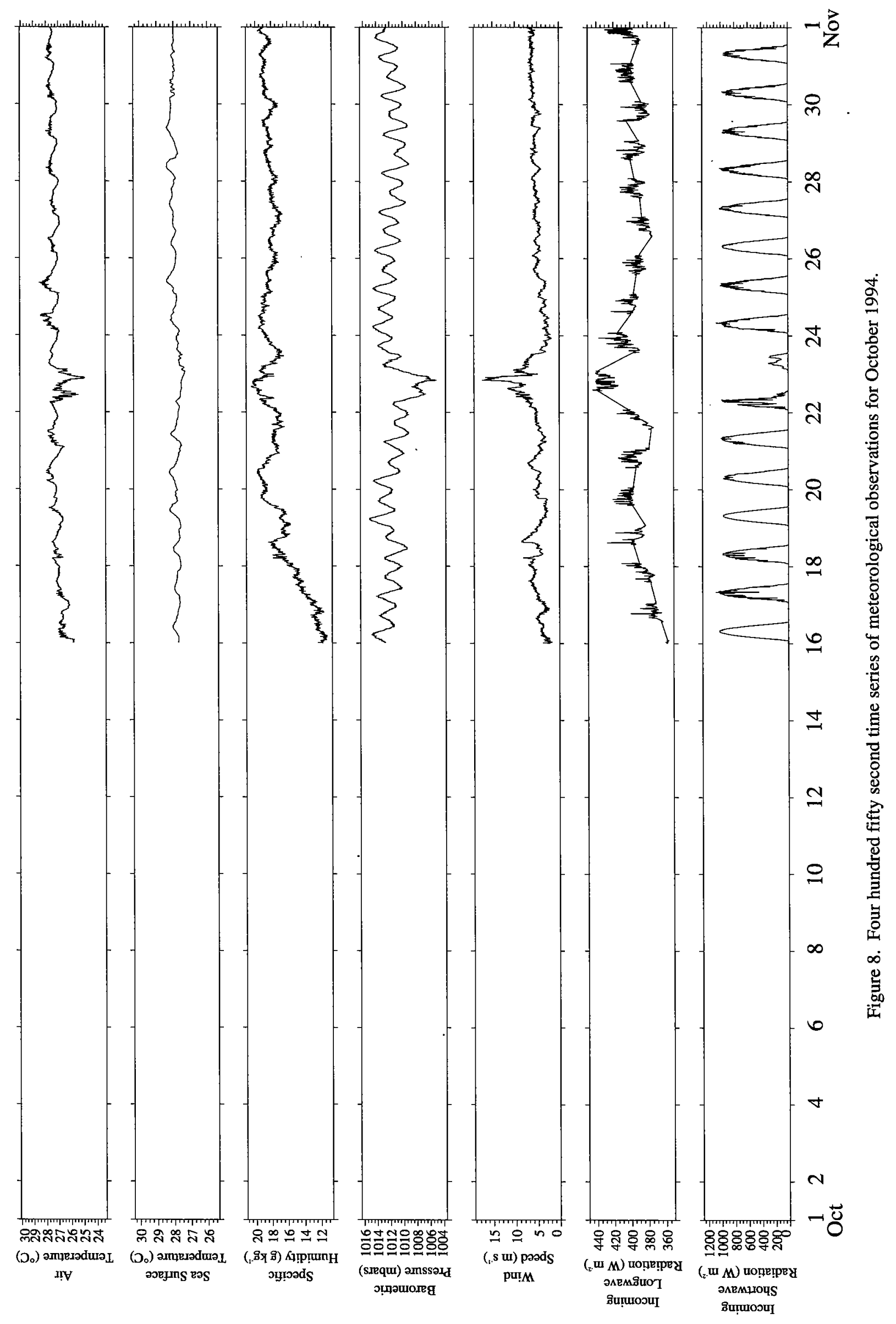




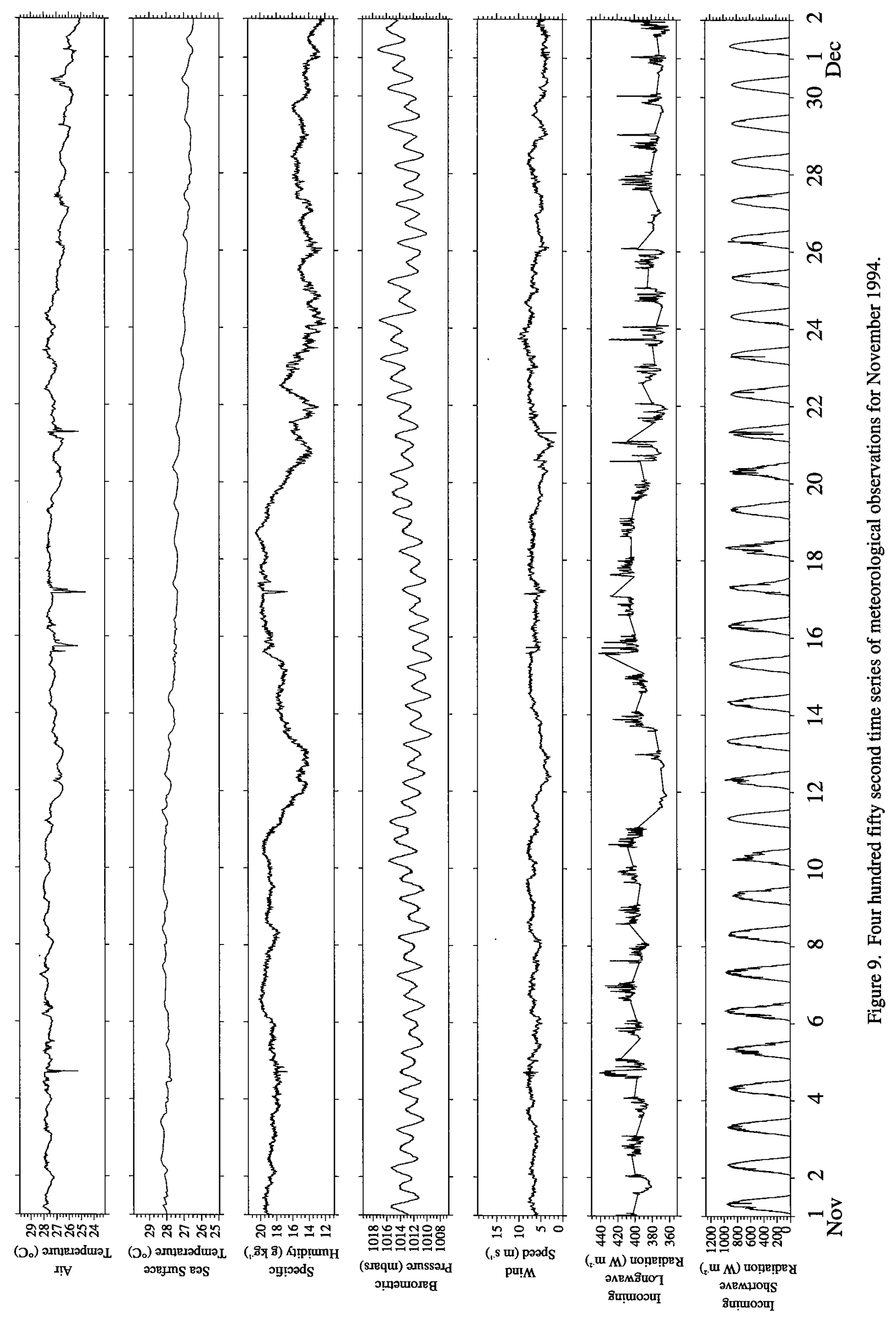




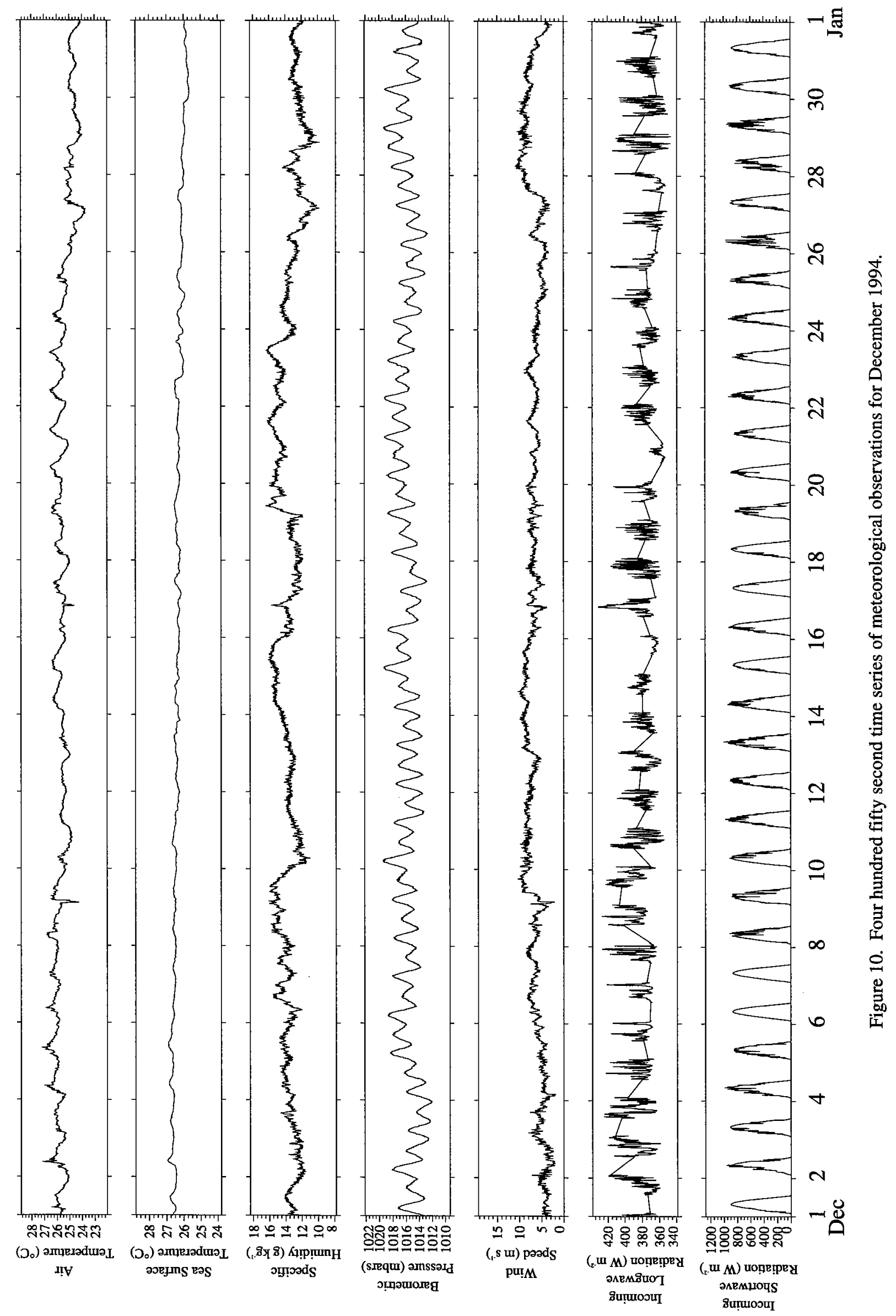




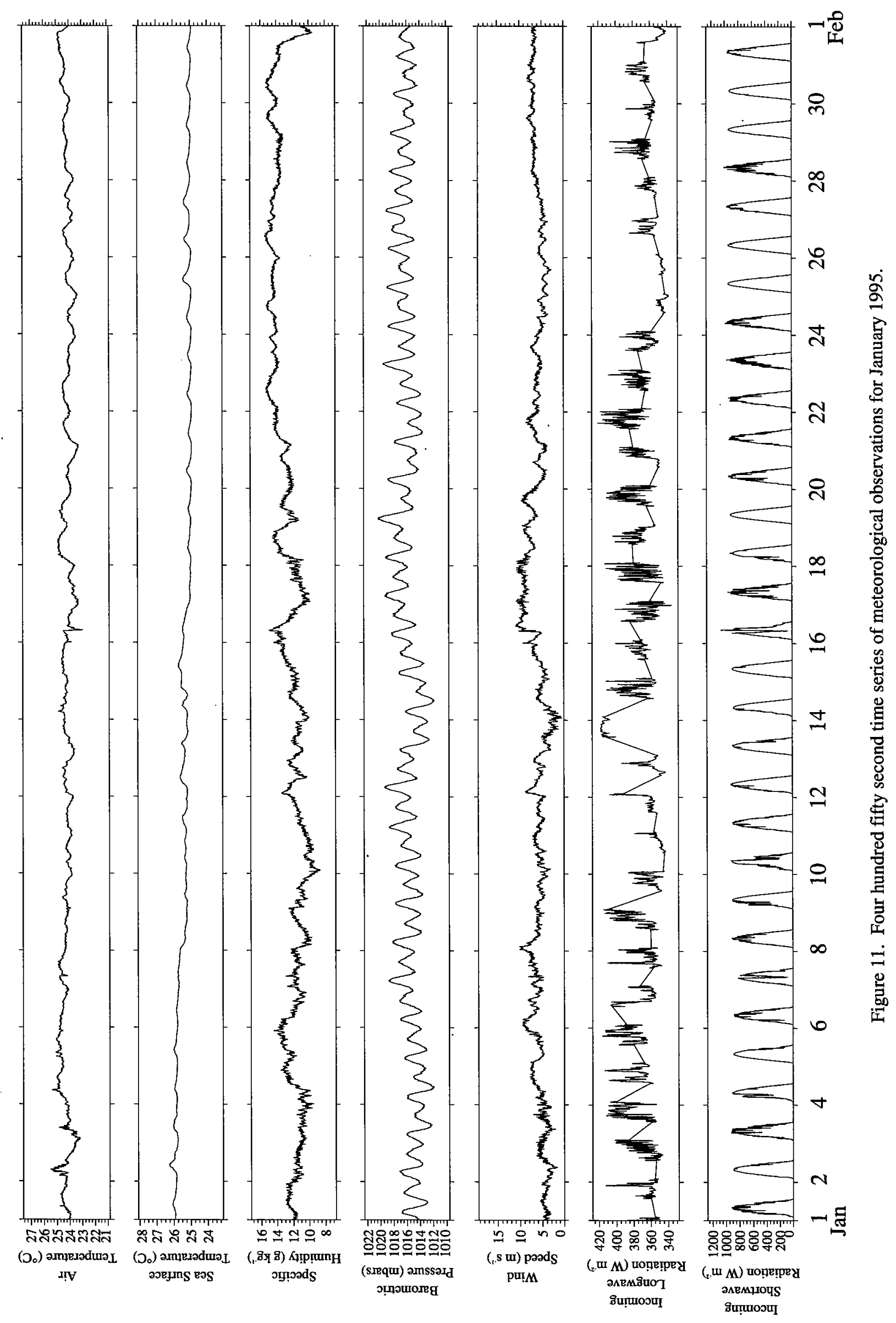




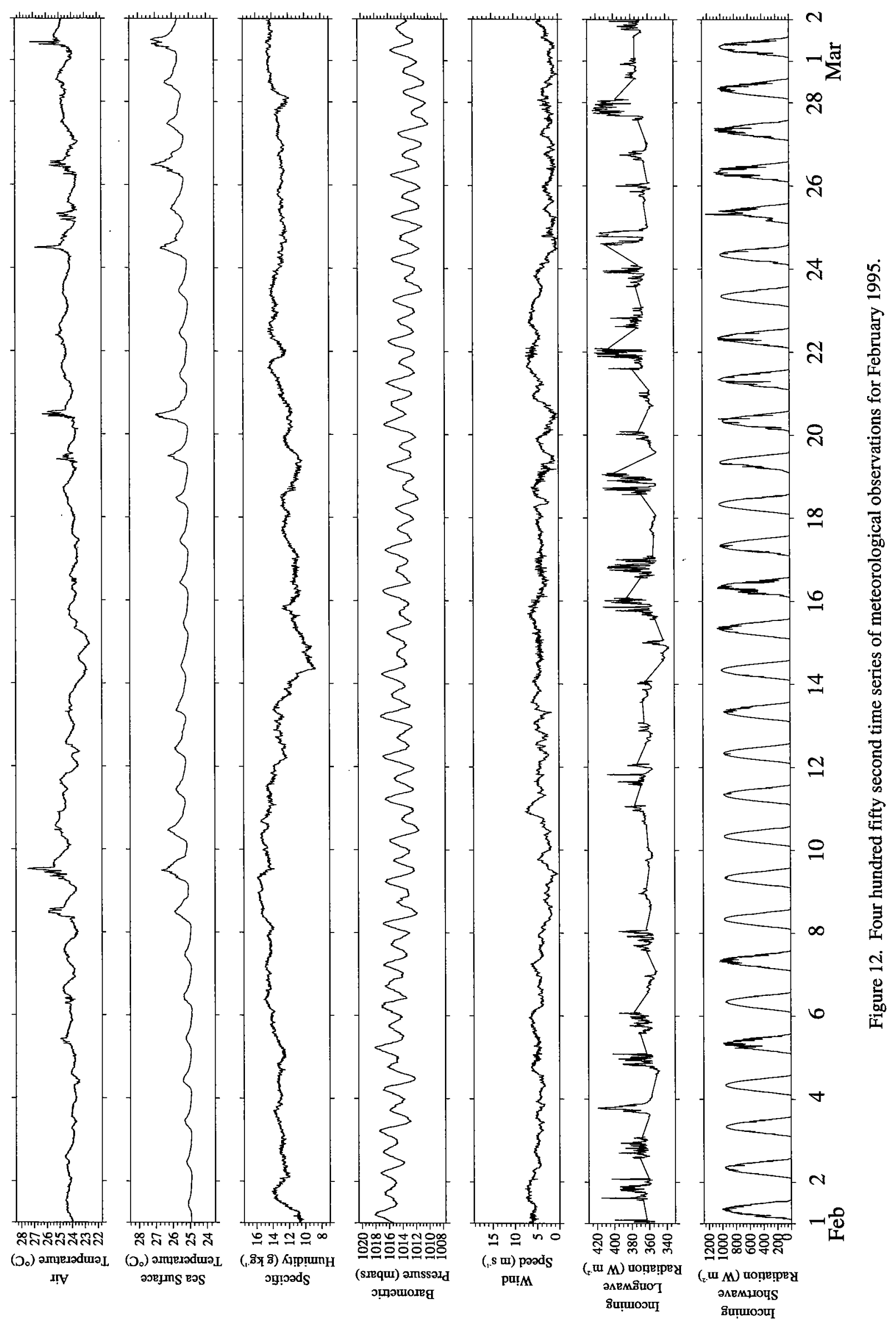




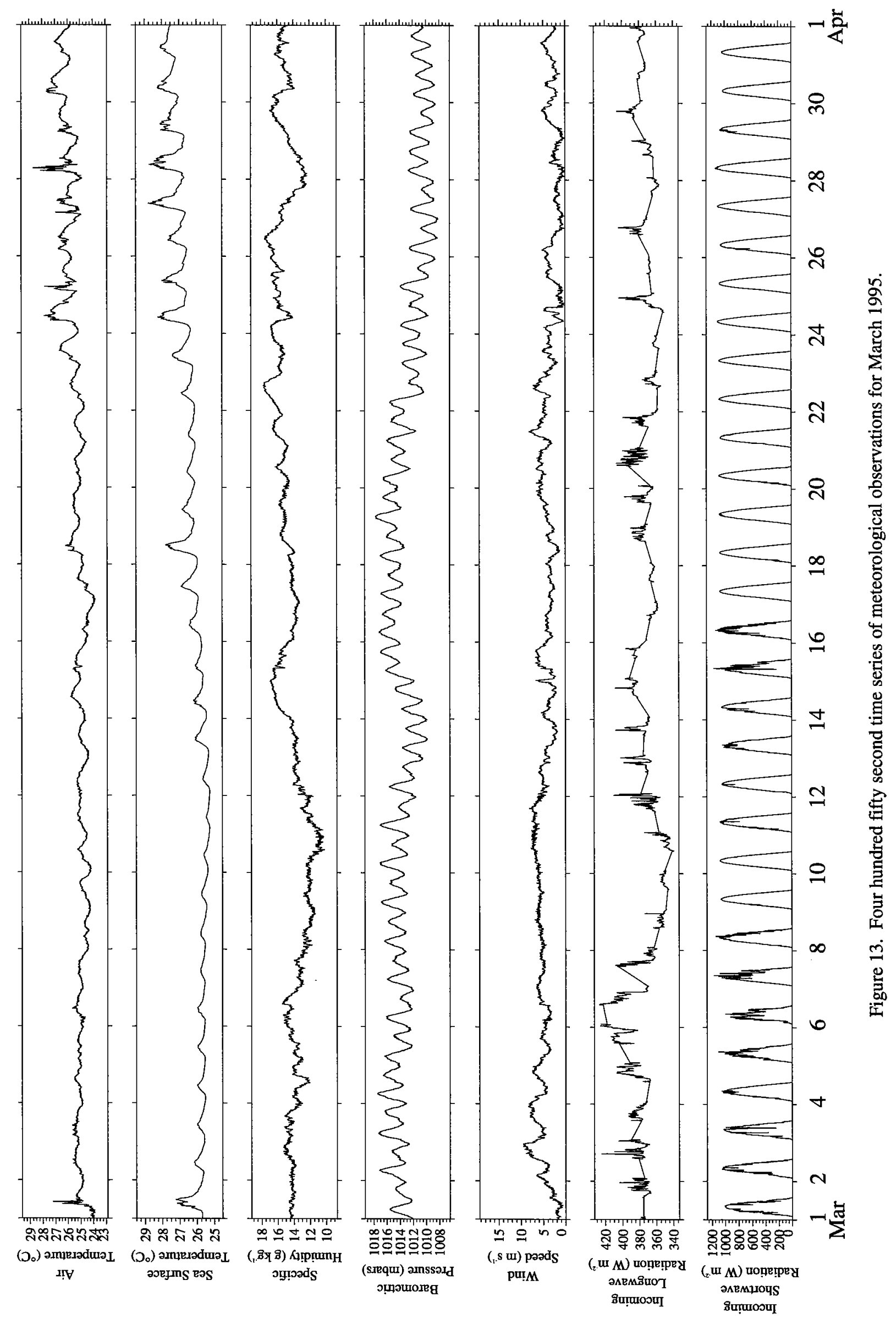




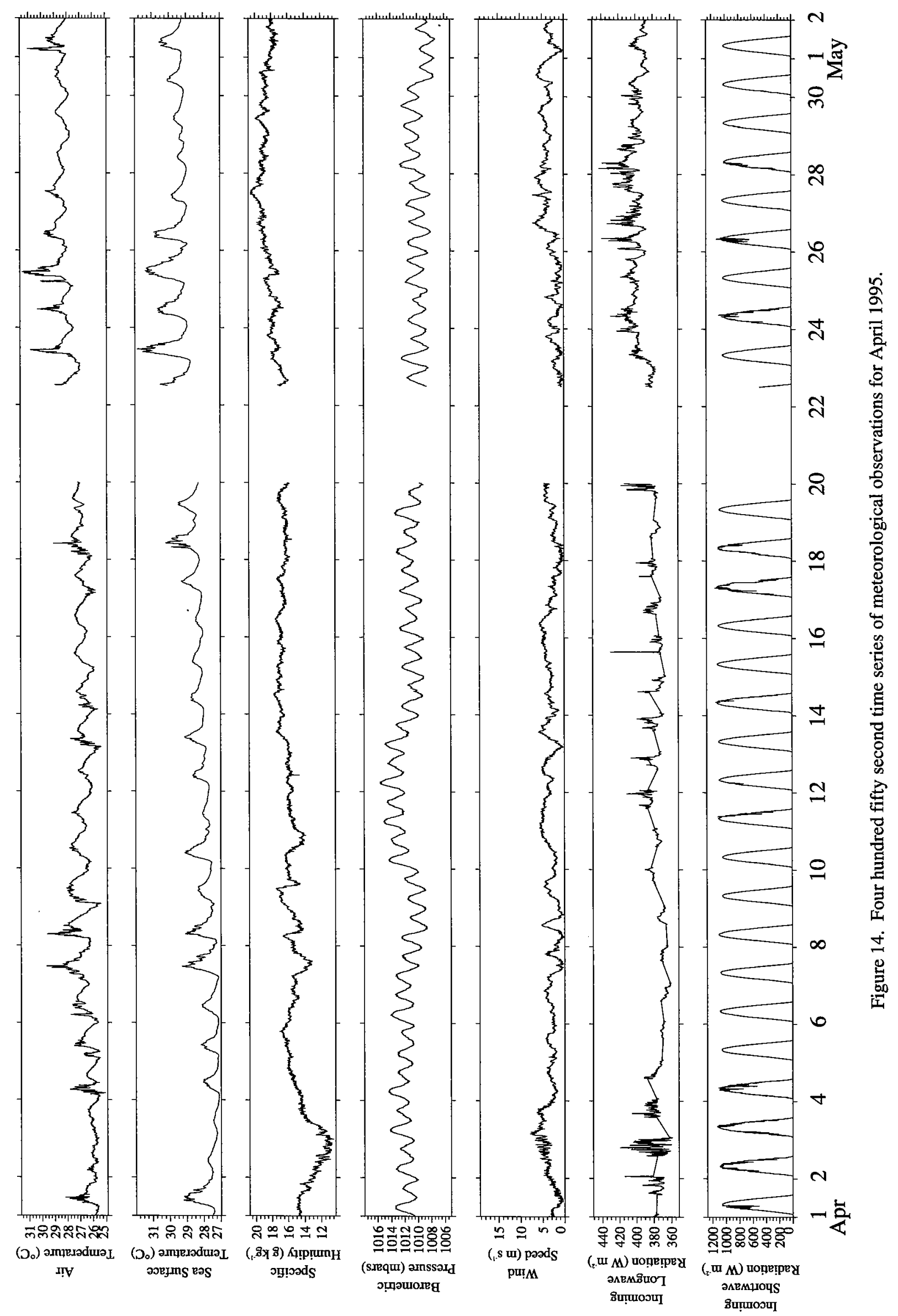




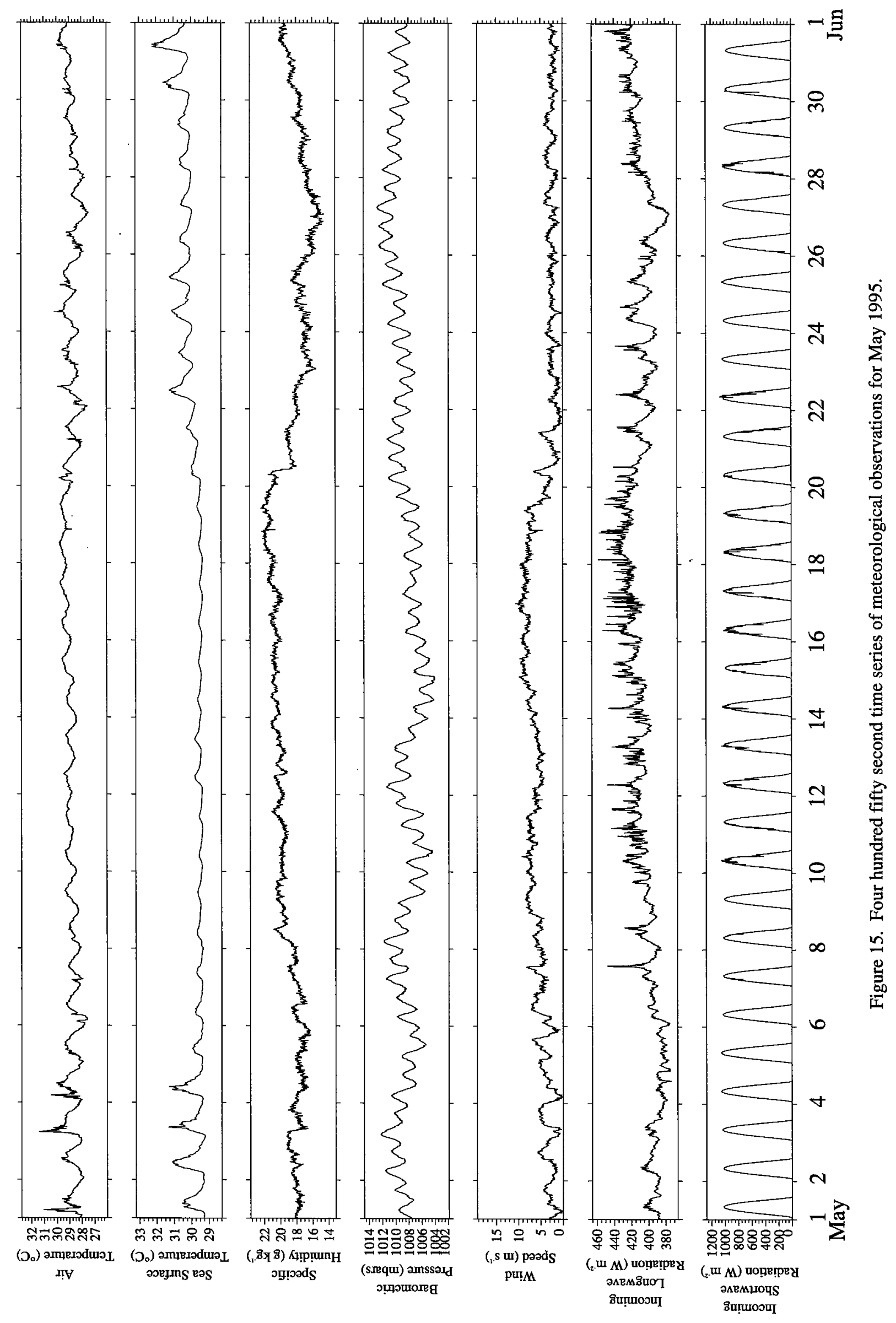




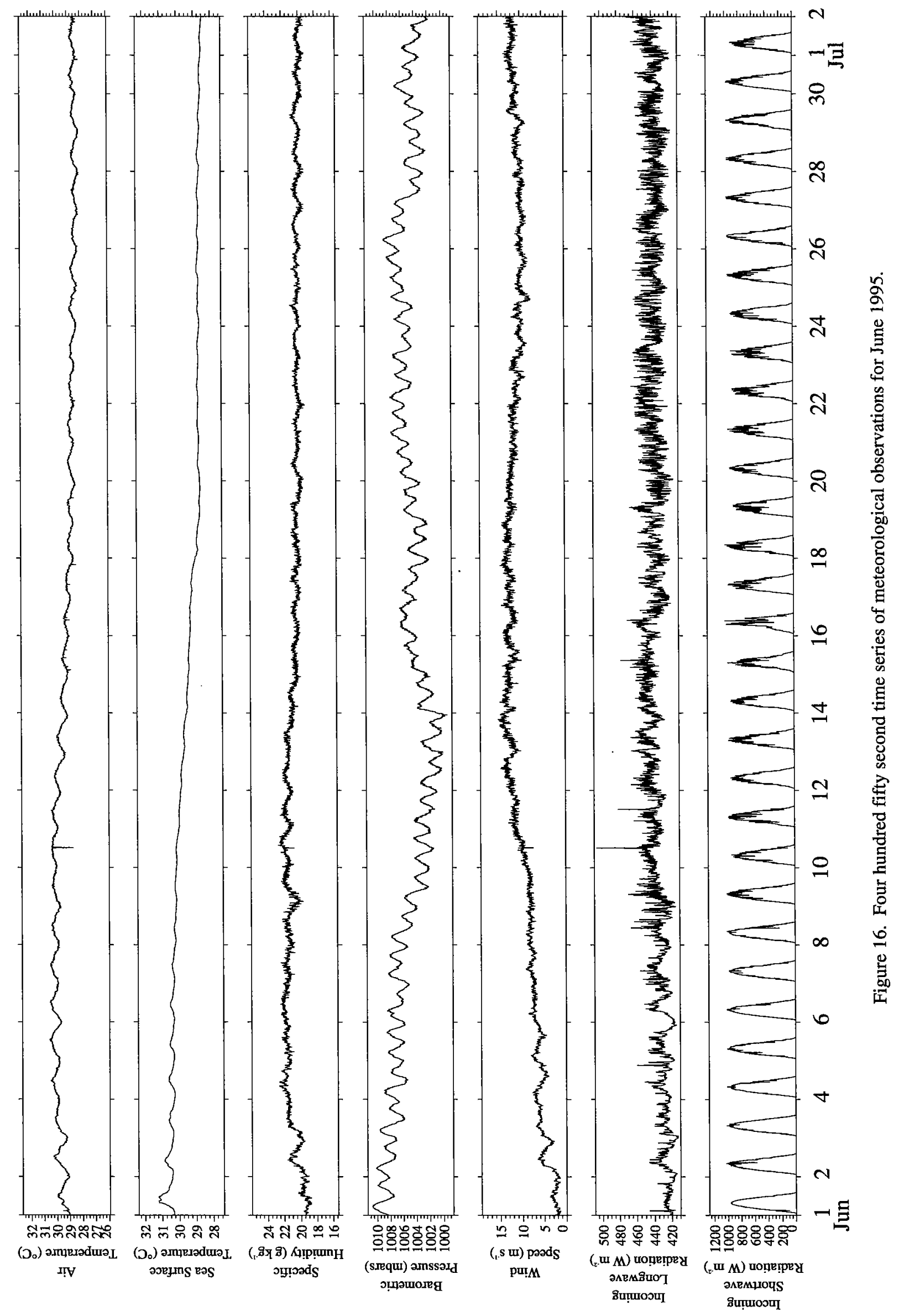




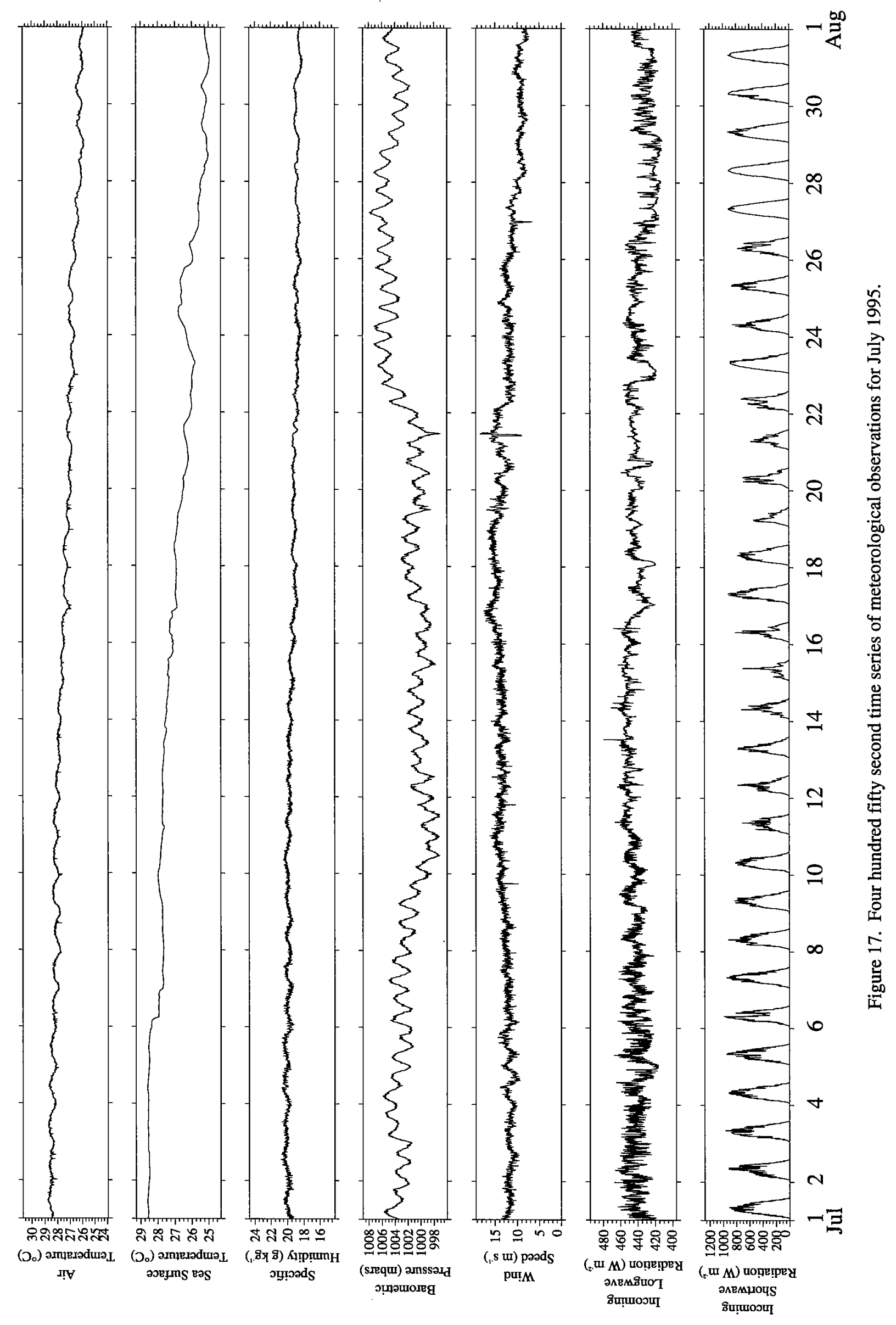




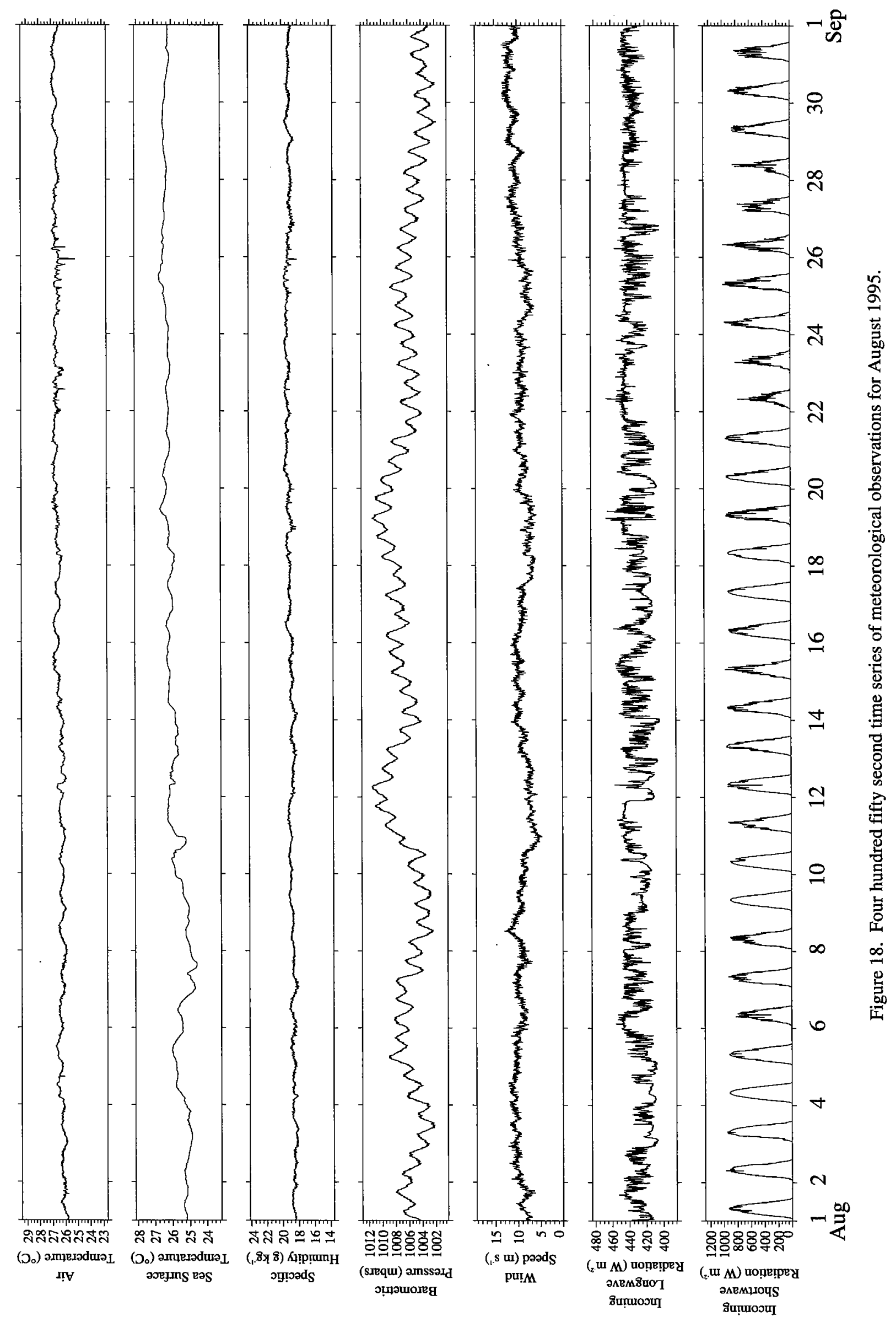




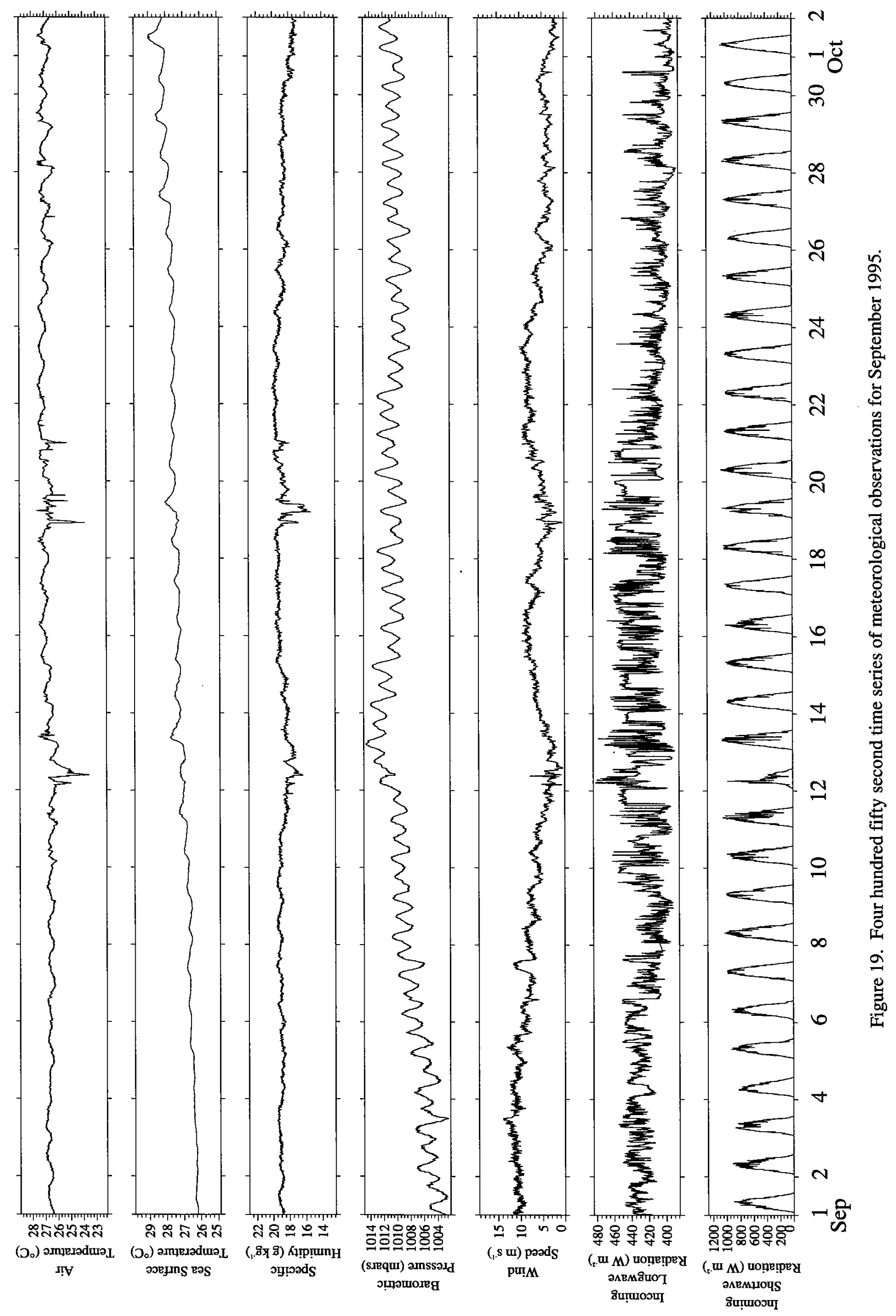




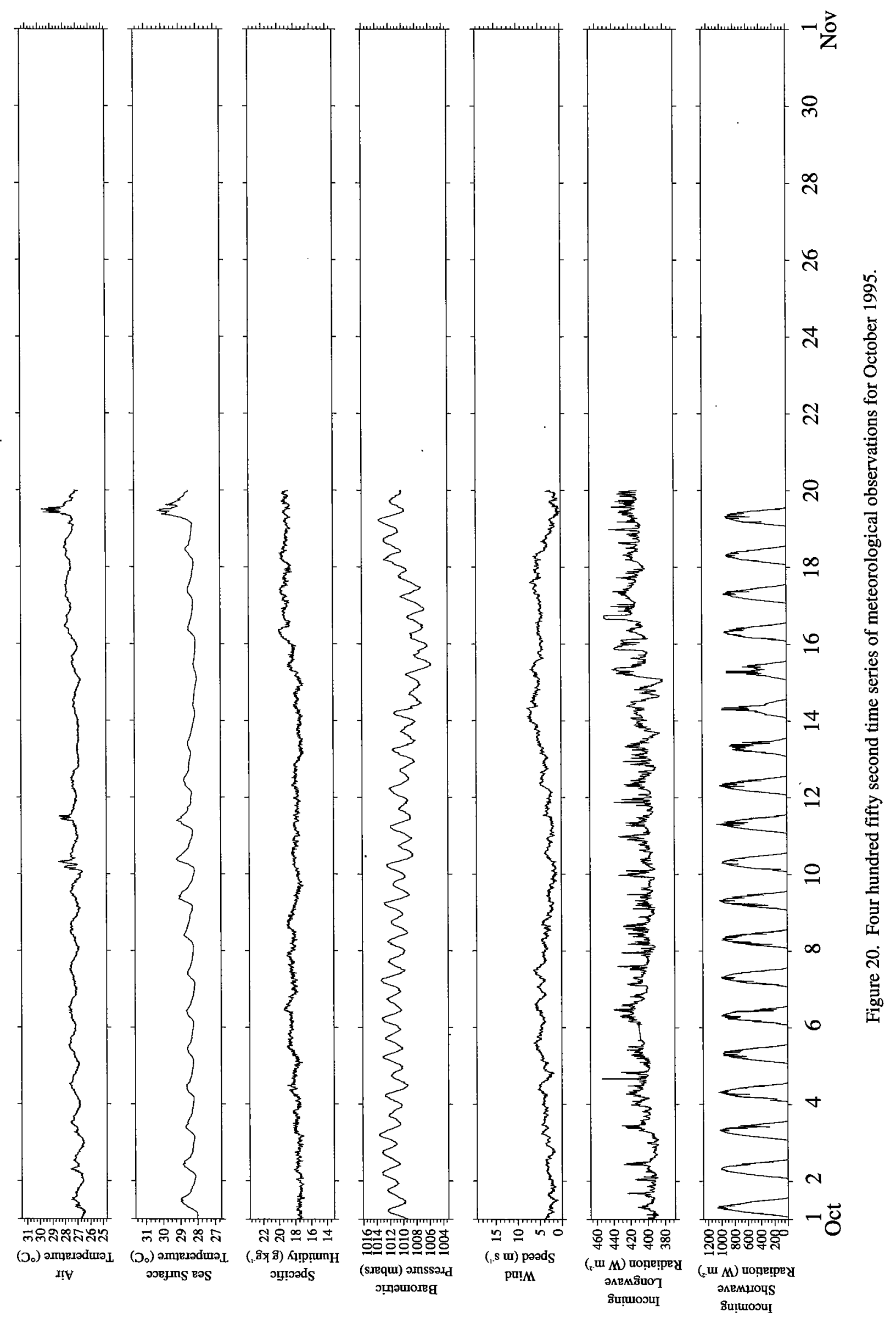



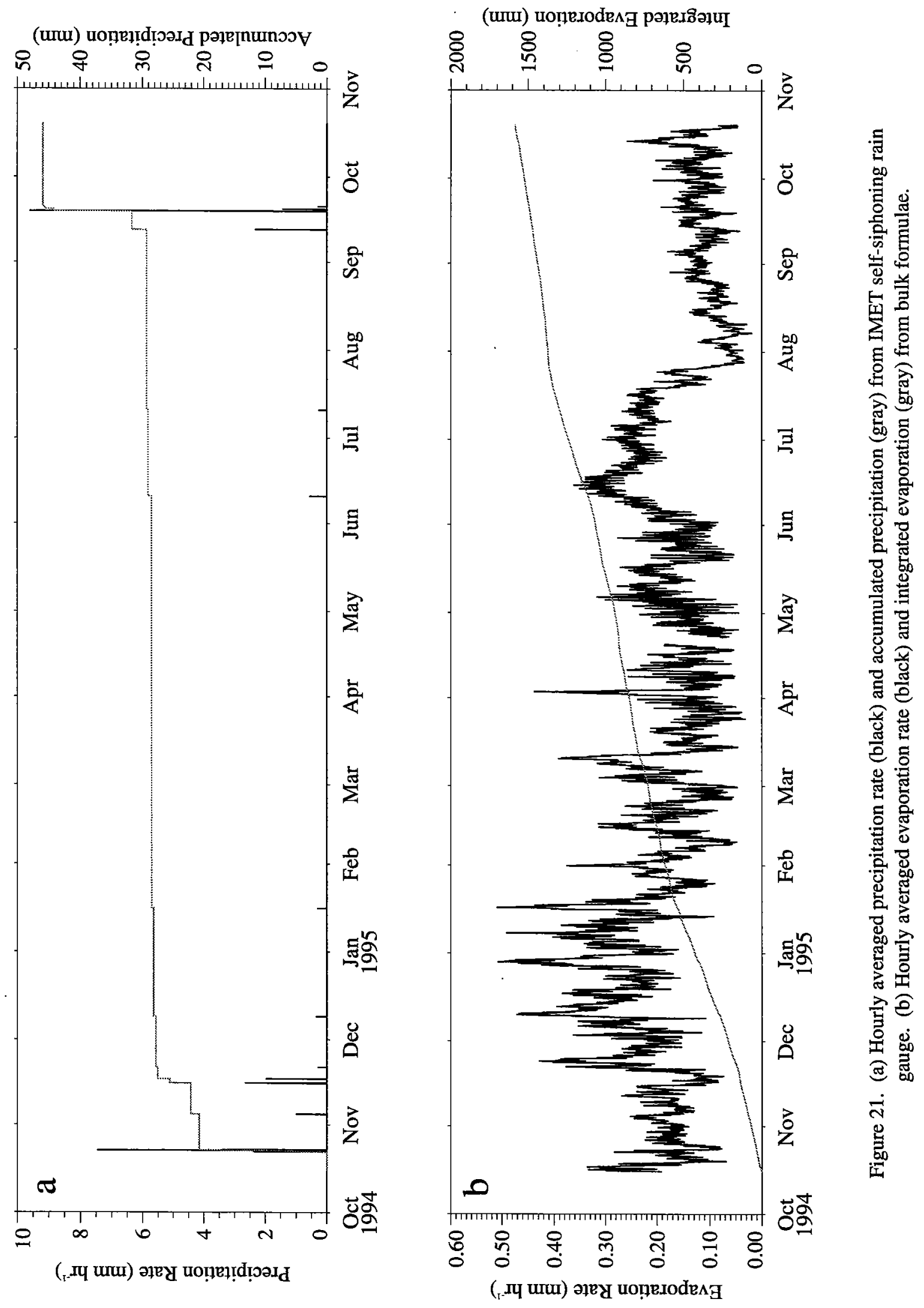


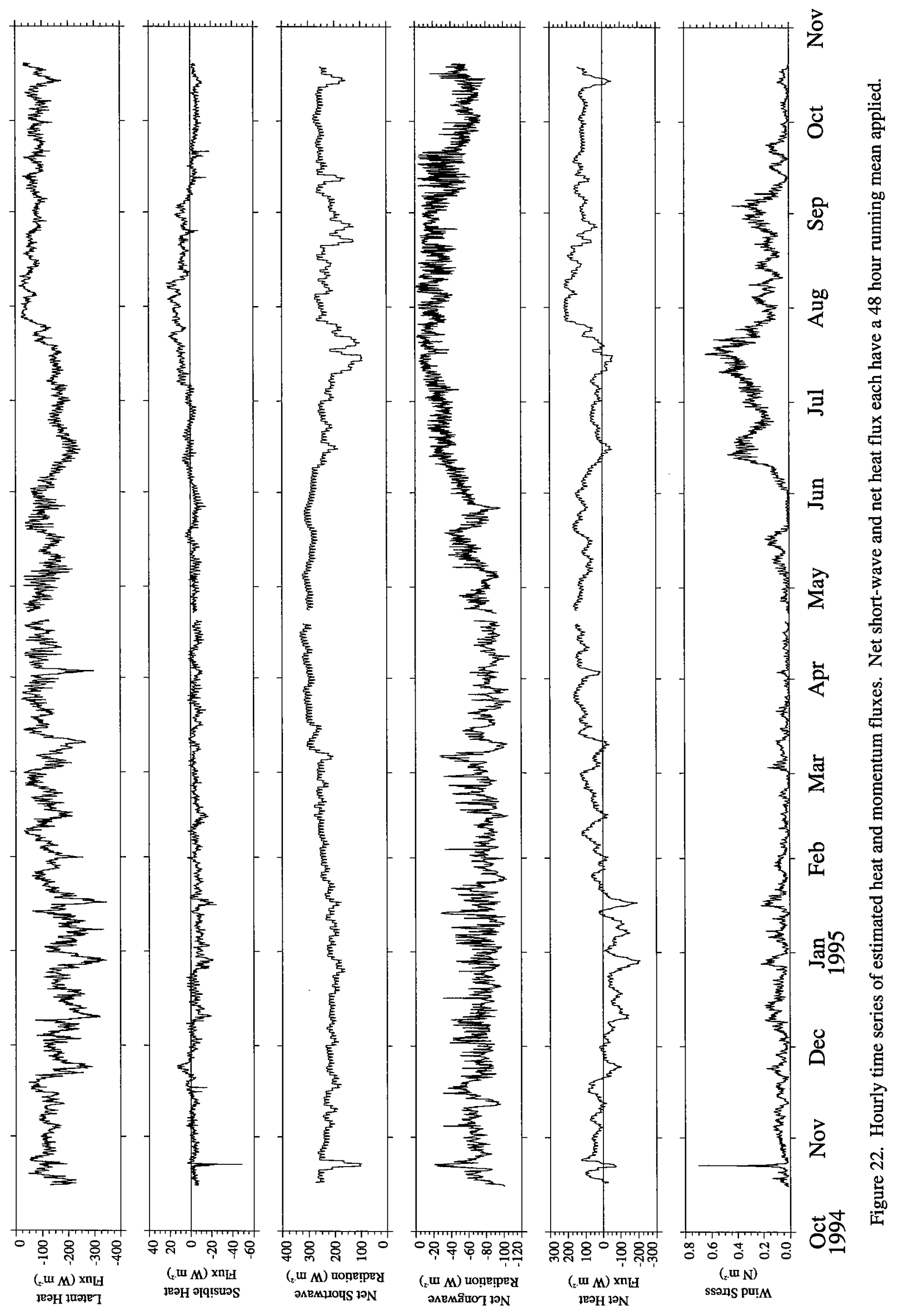




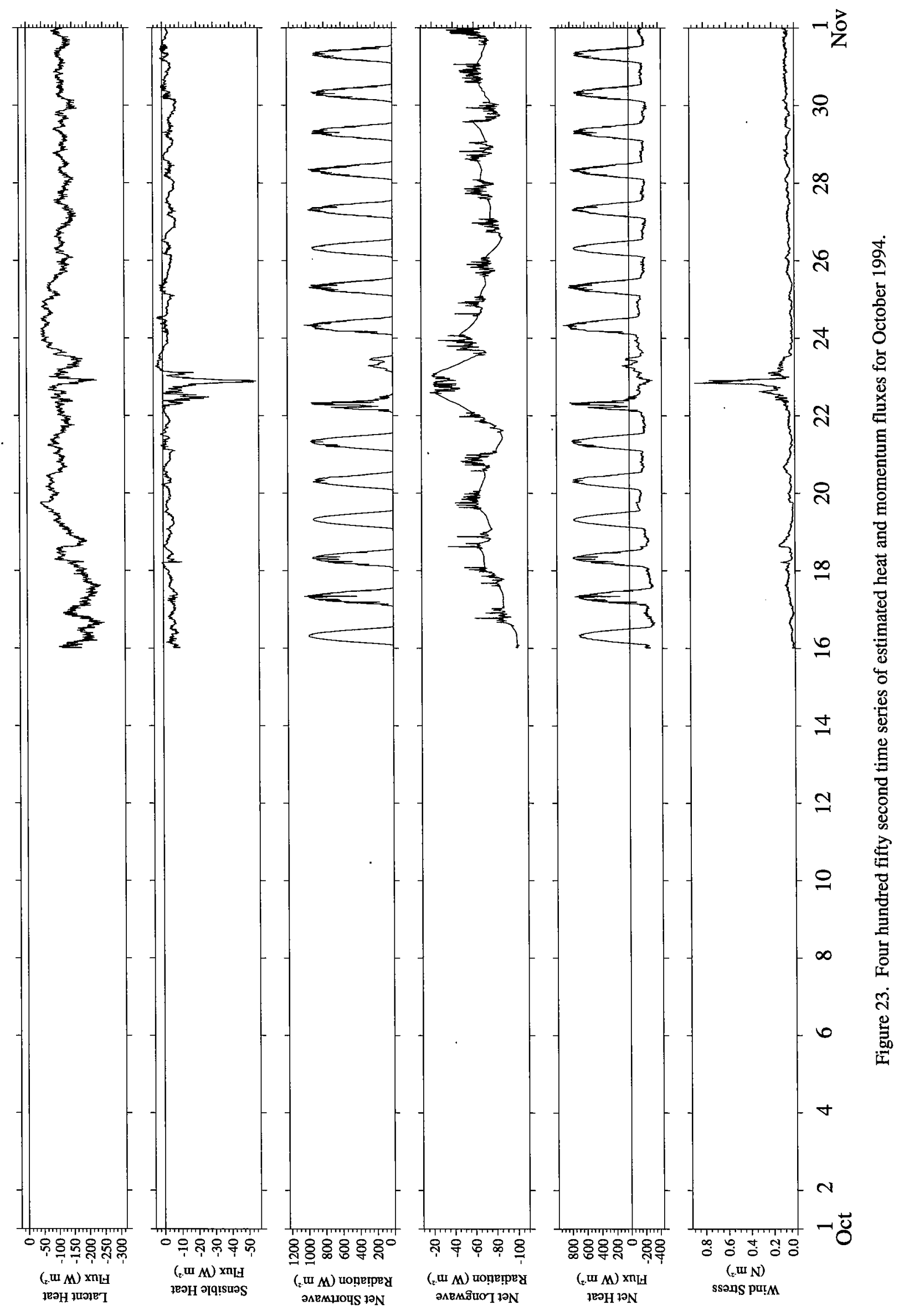




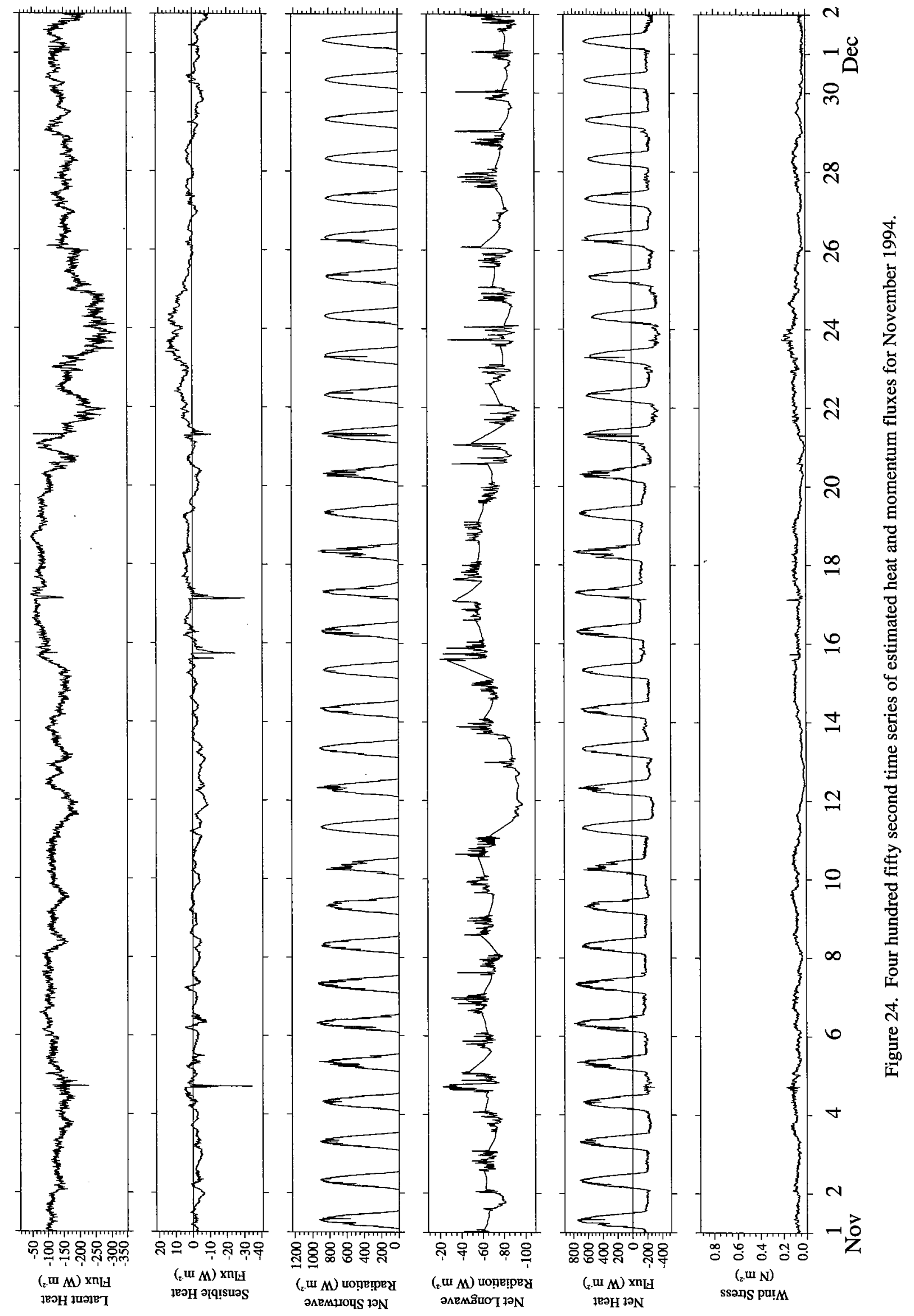




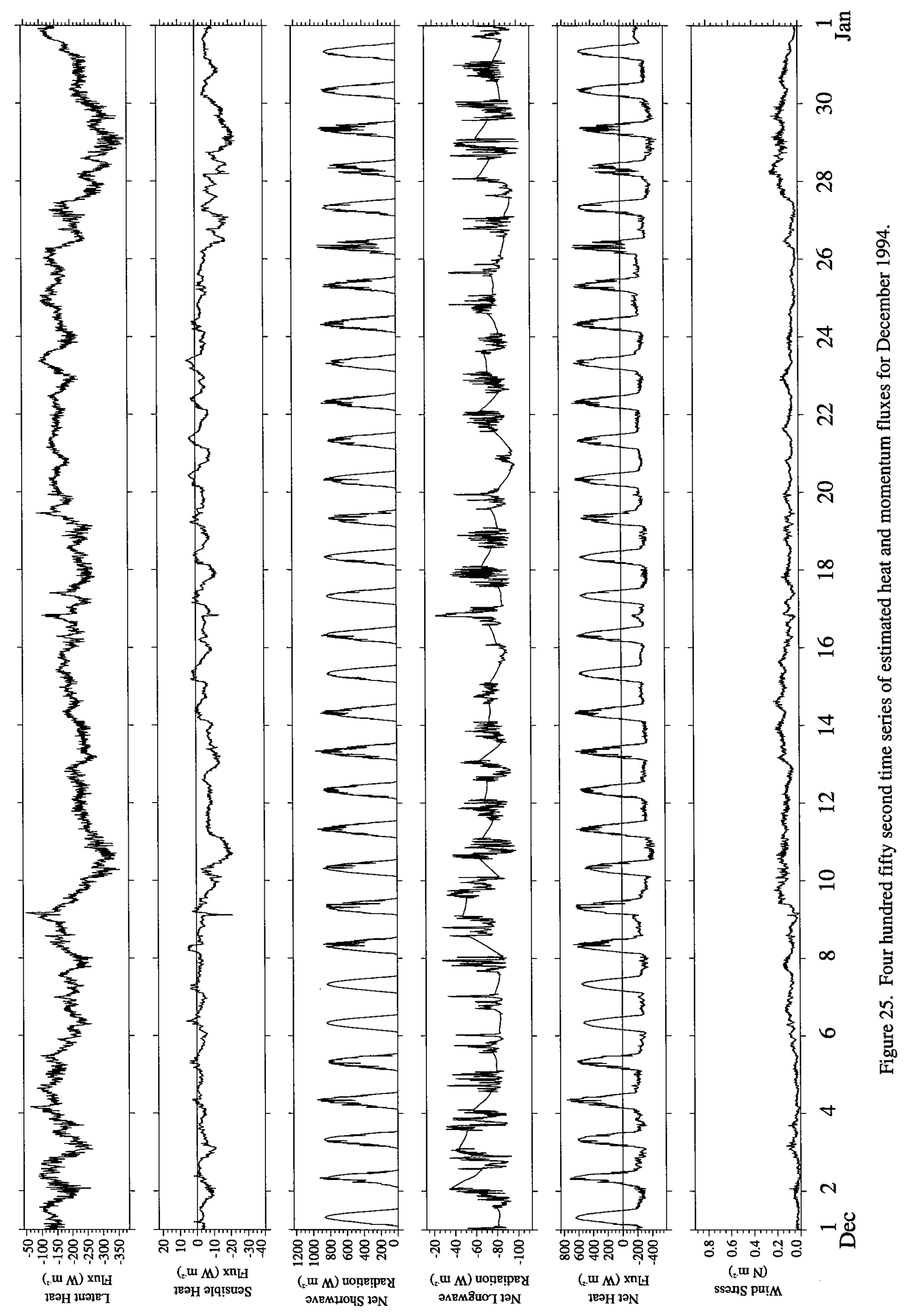




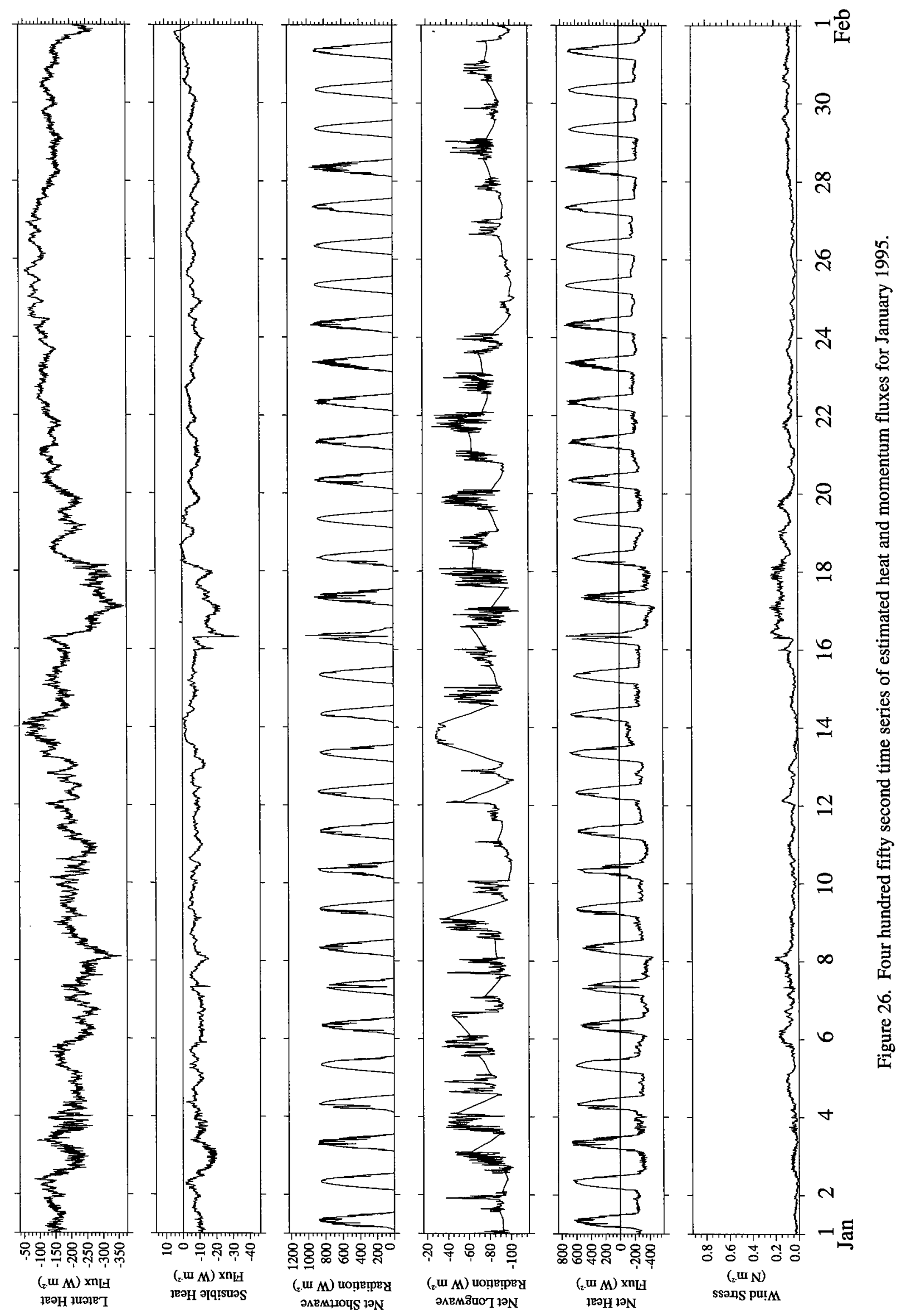




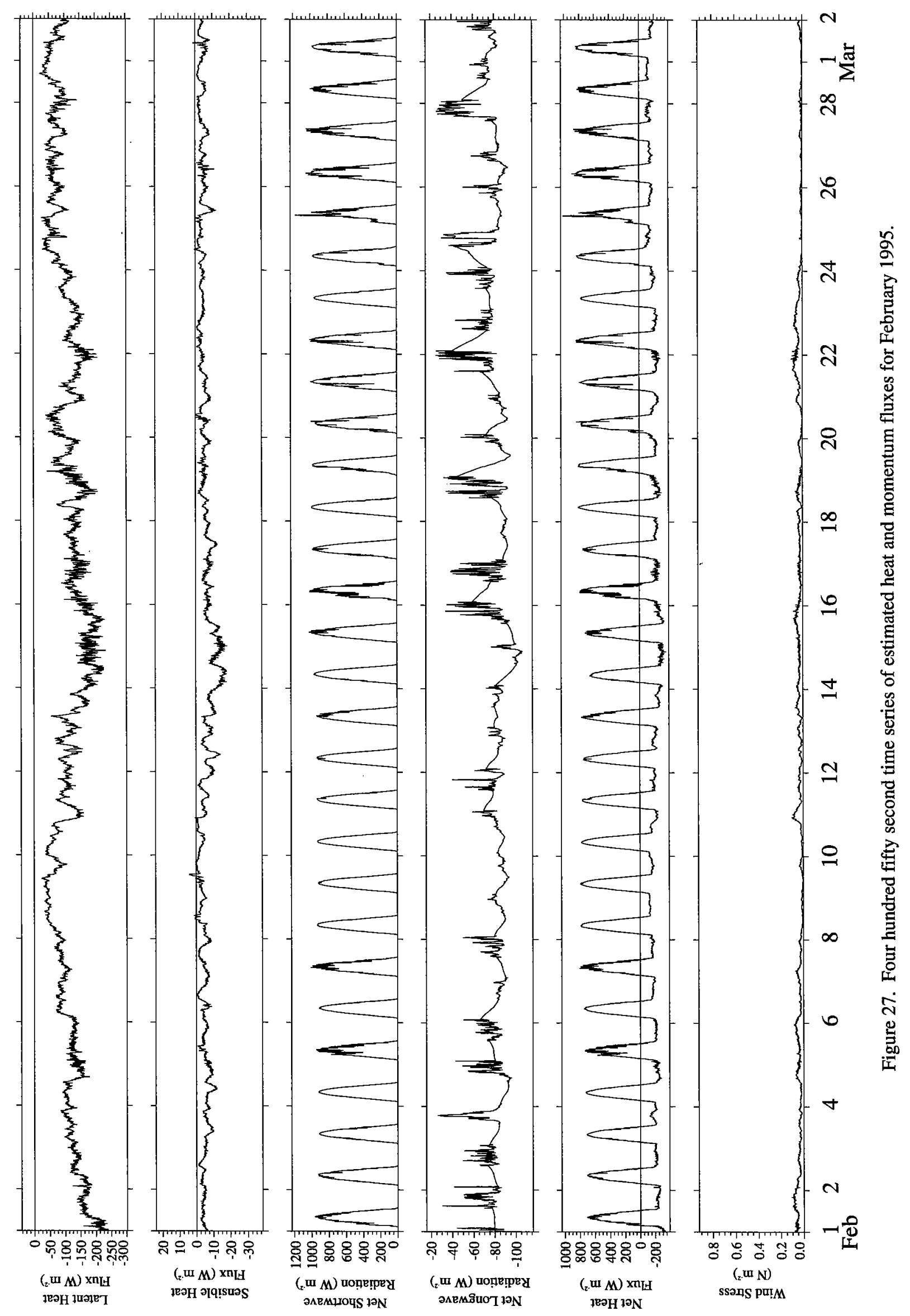




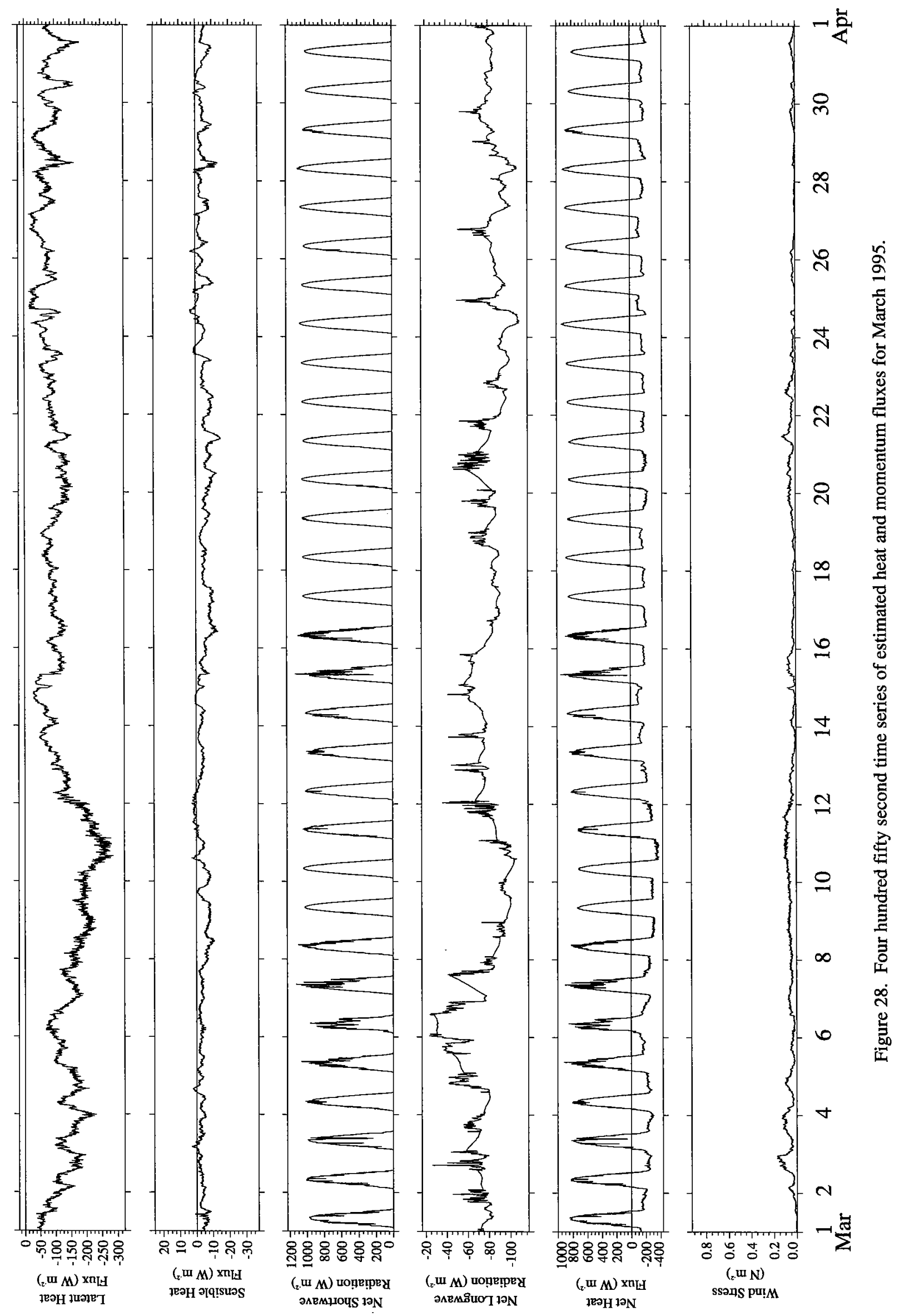




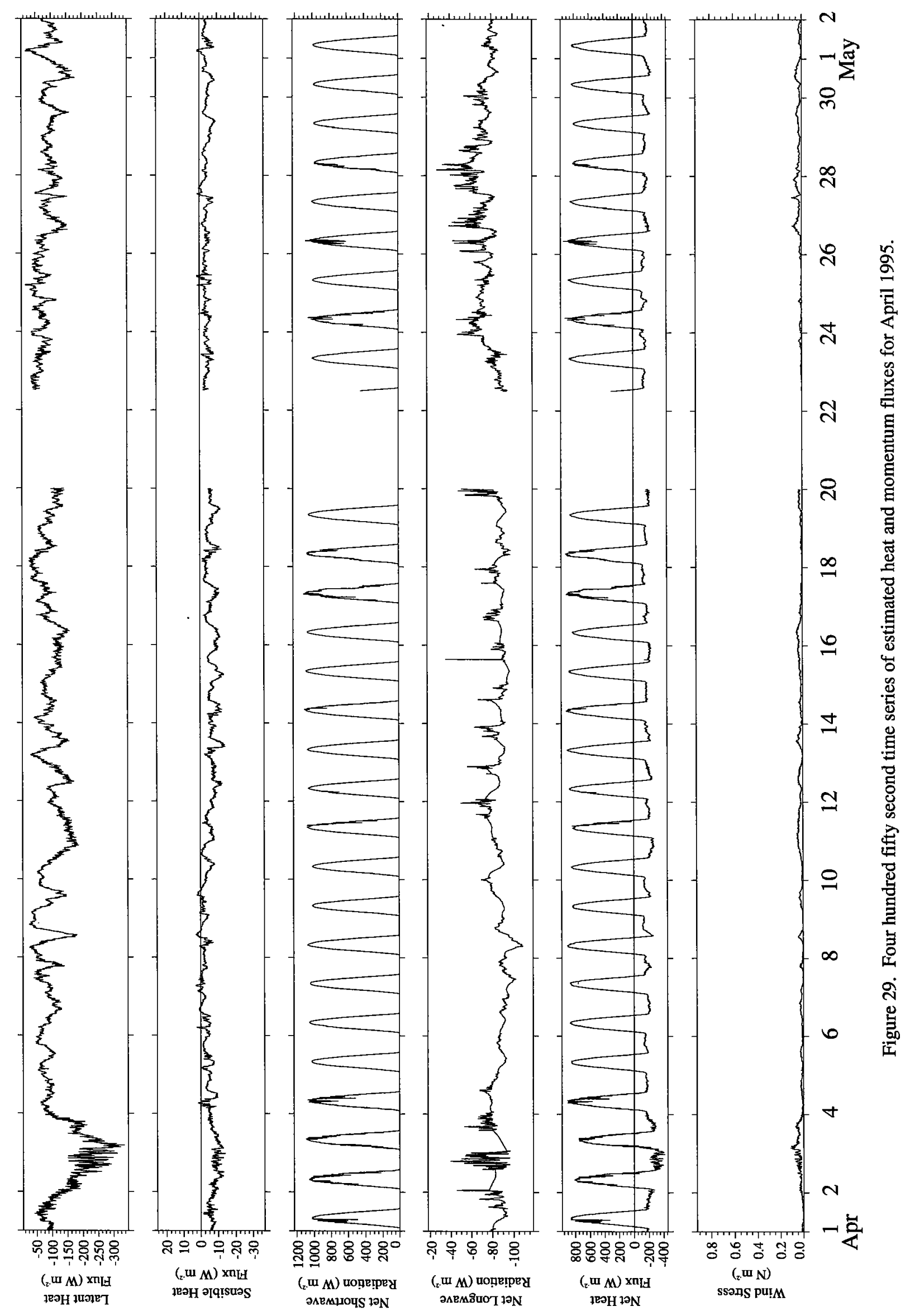




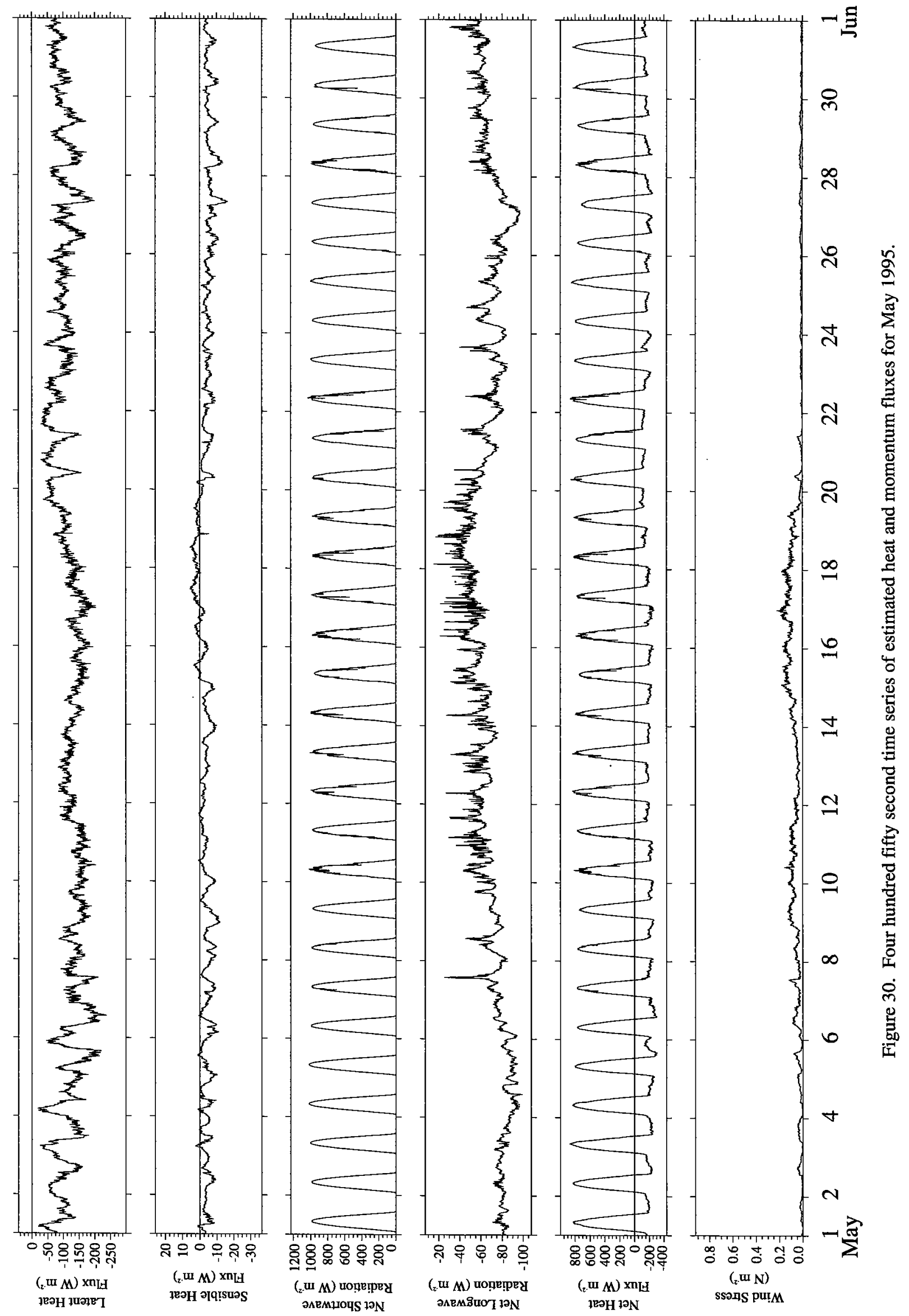




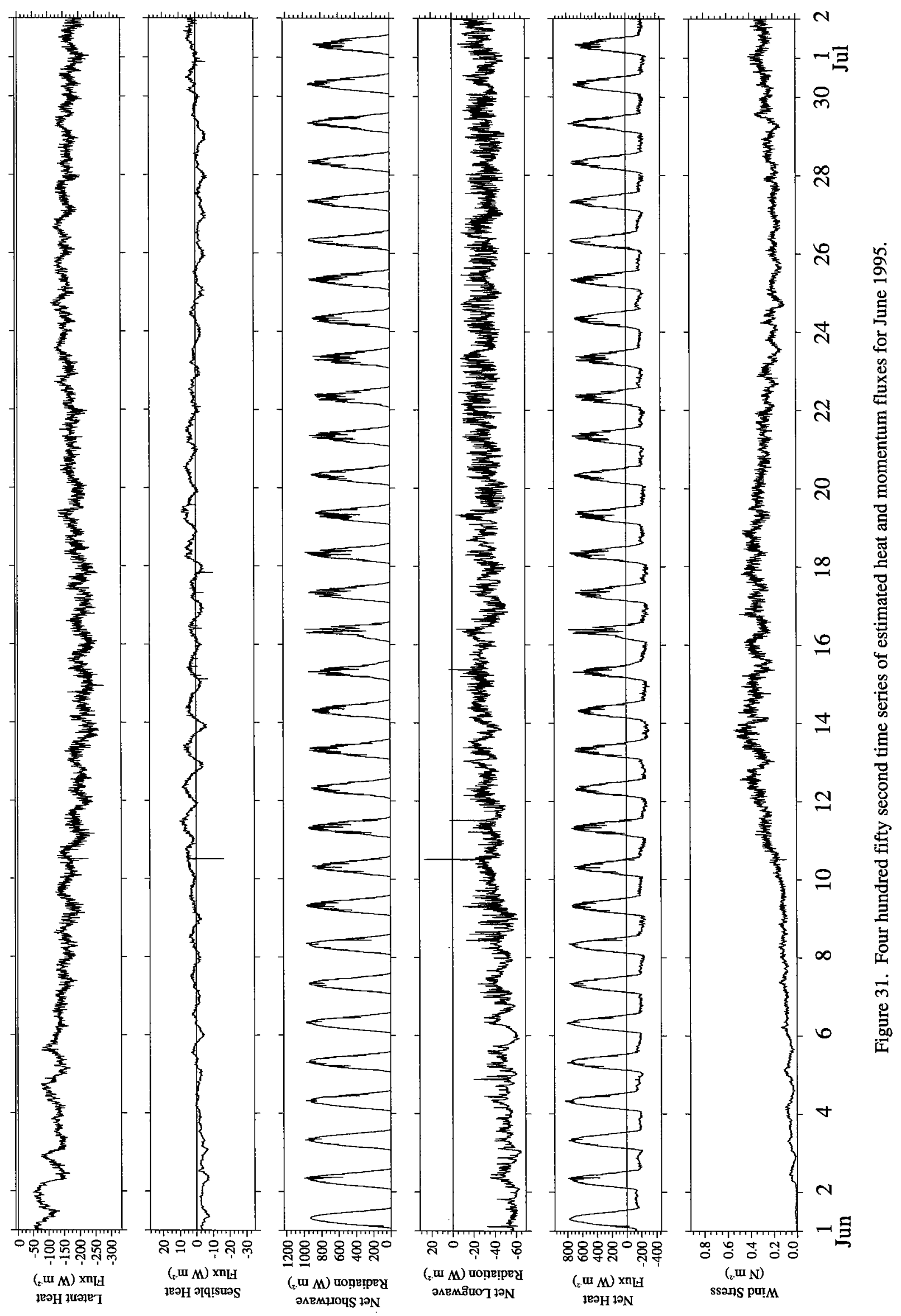




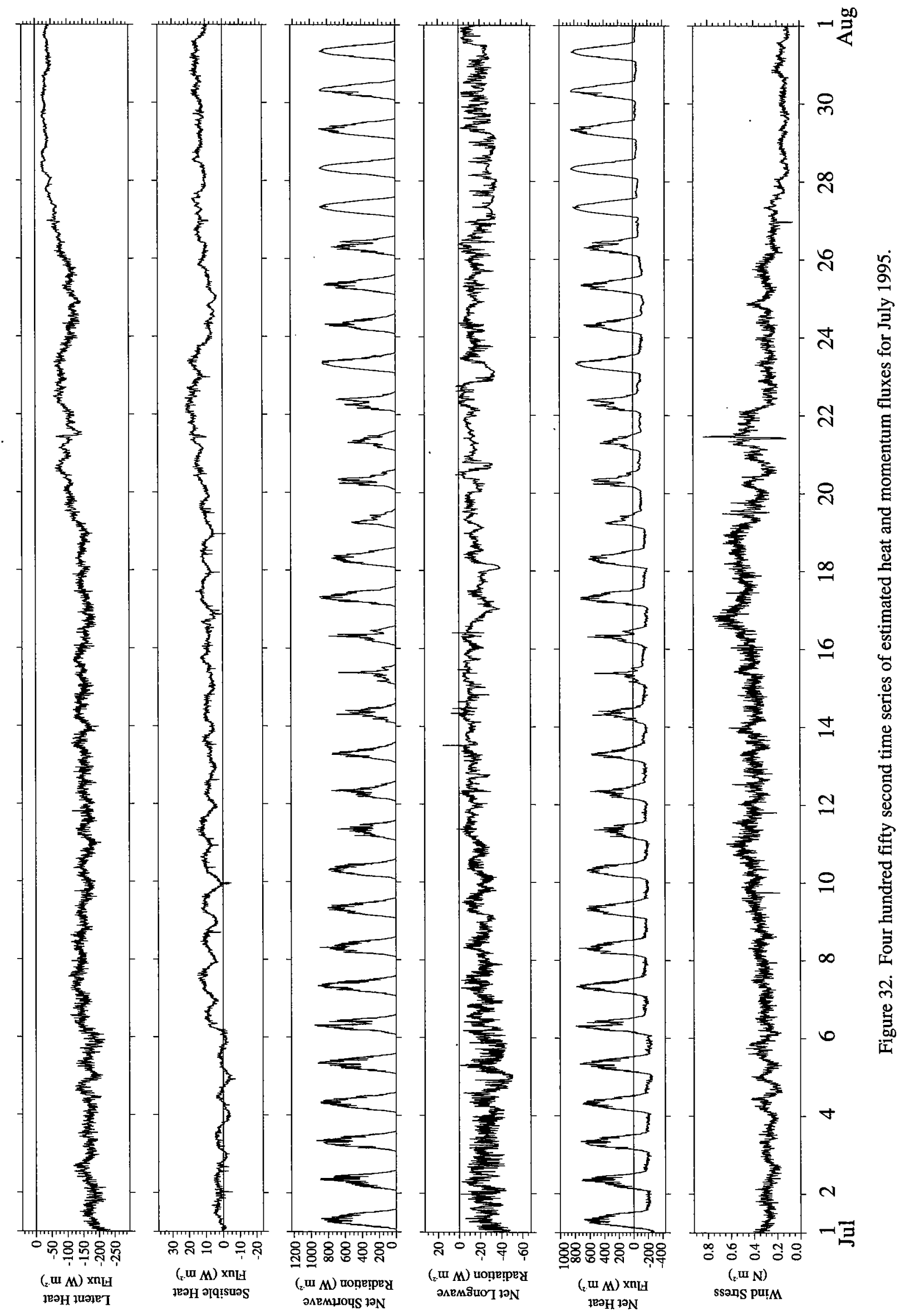




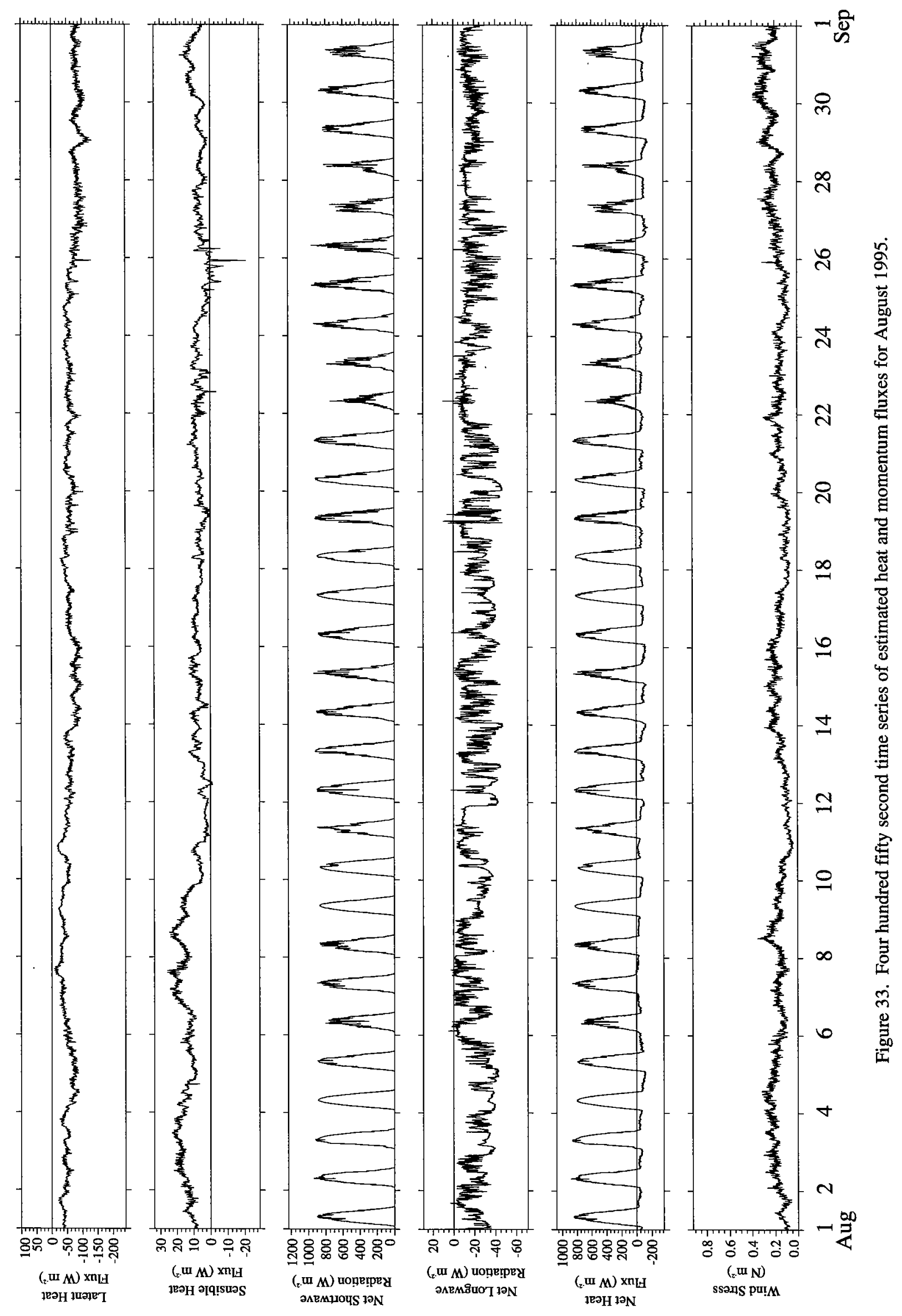




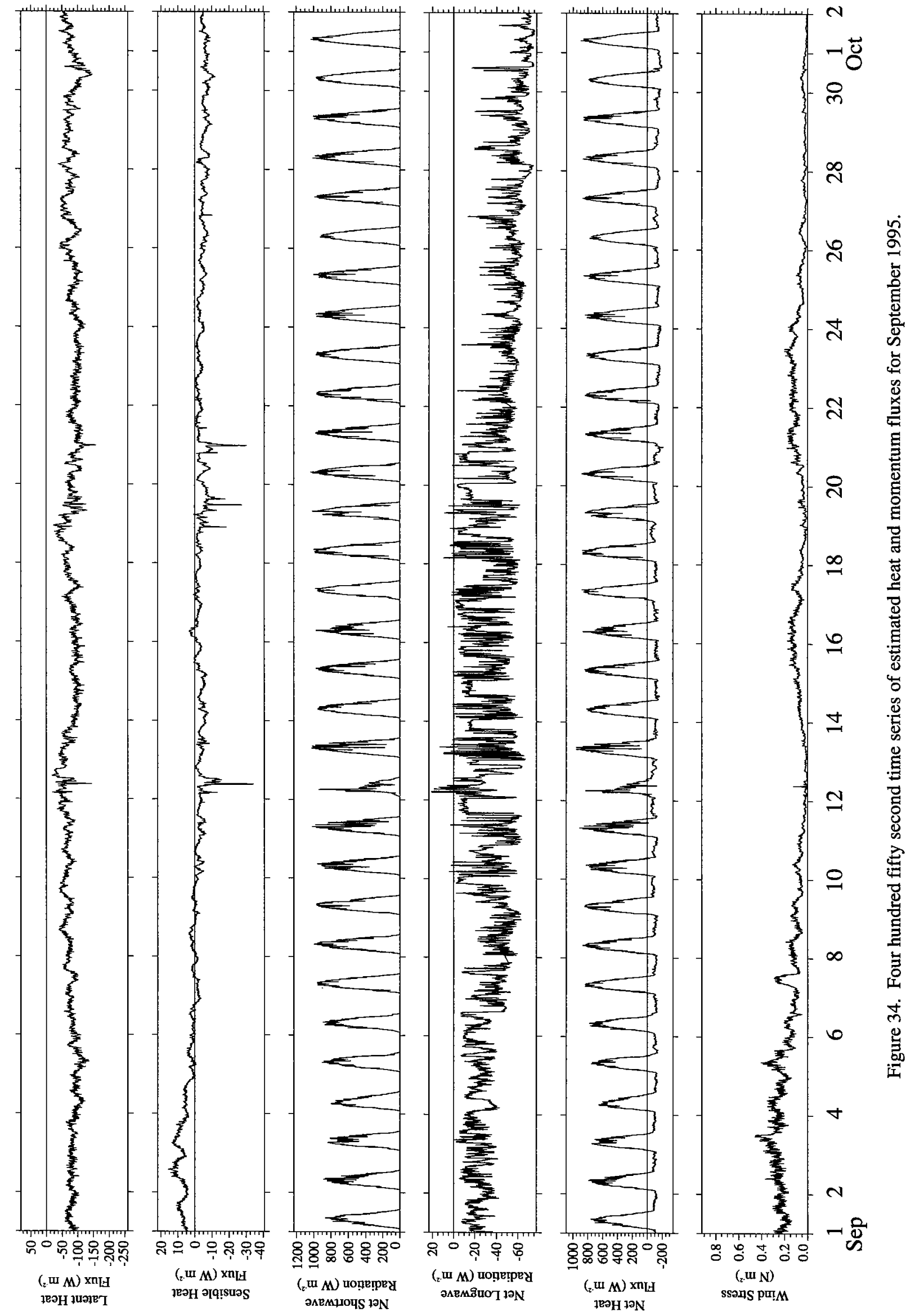




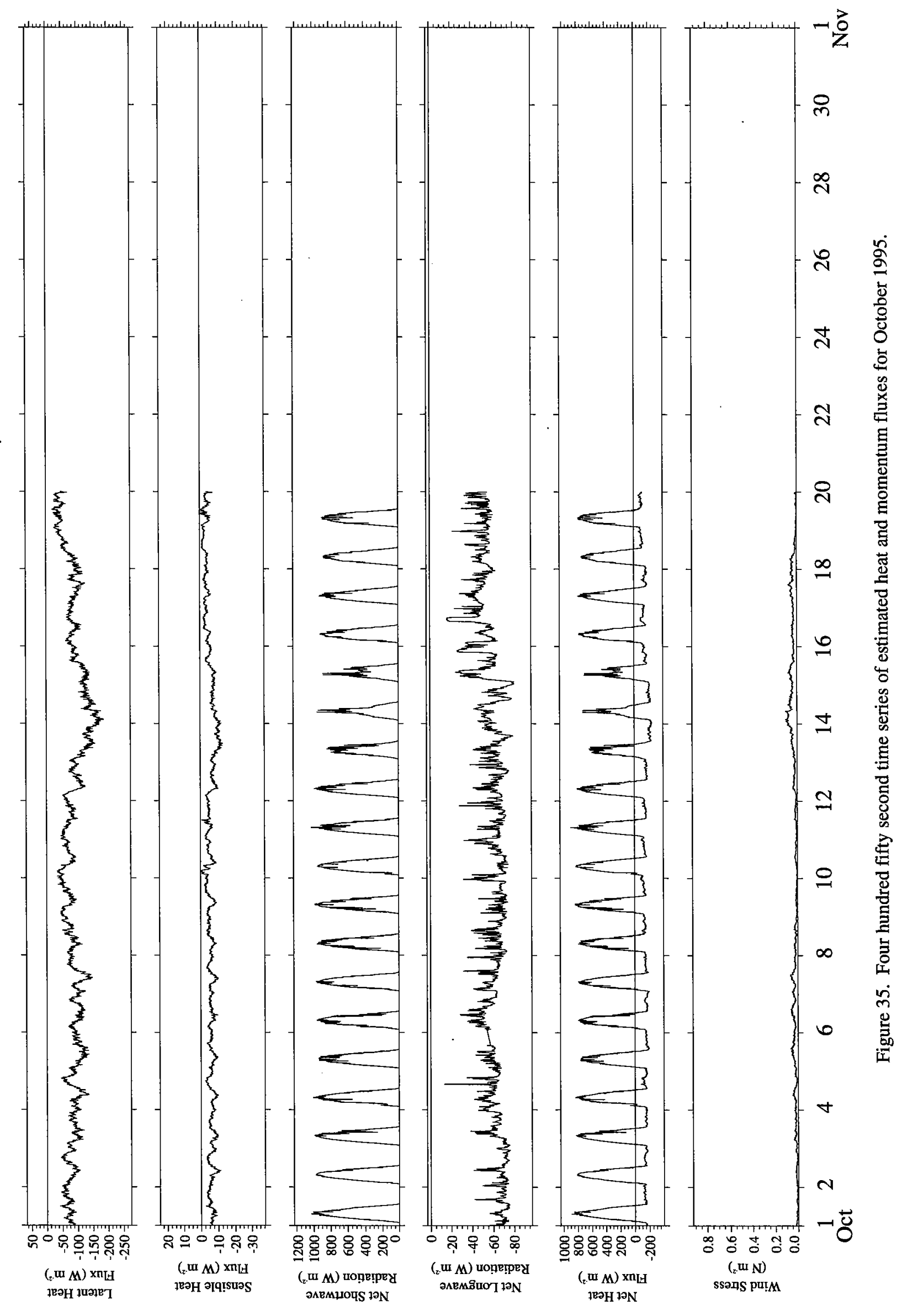




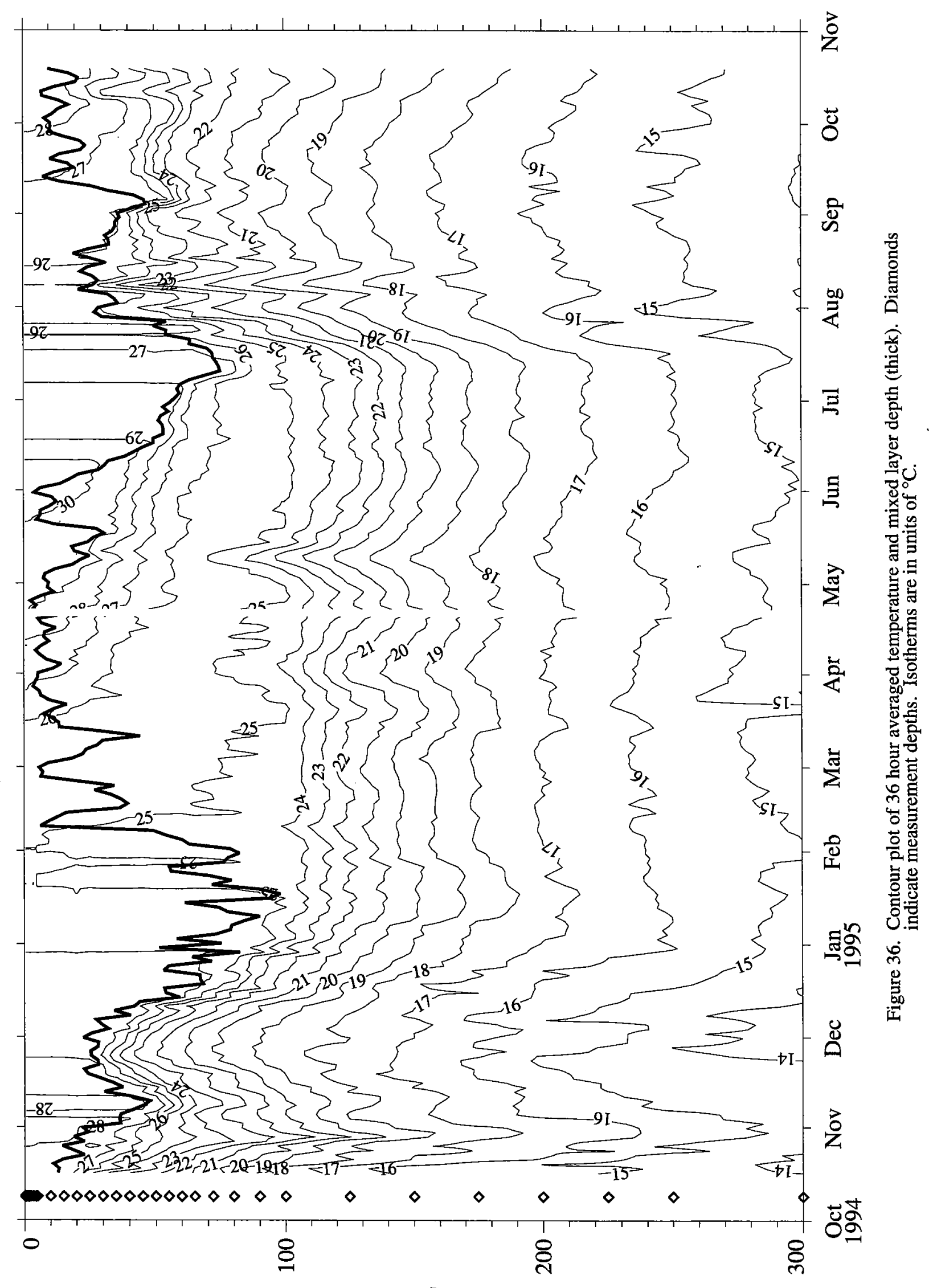

(u) чฺdəव 


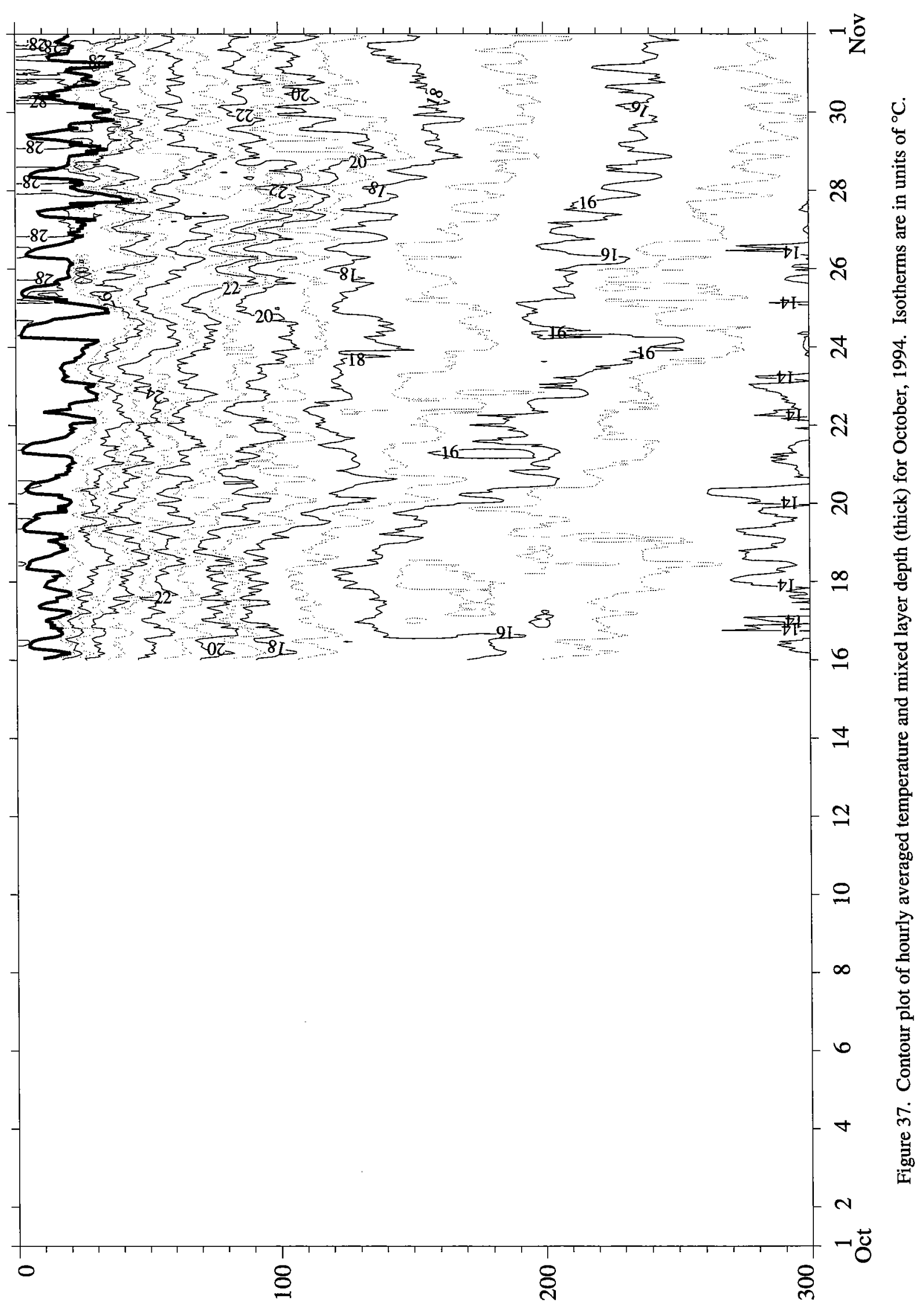

(ui) पıdә्व 


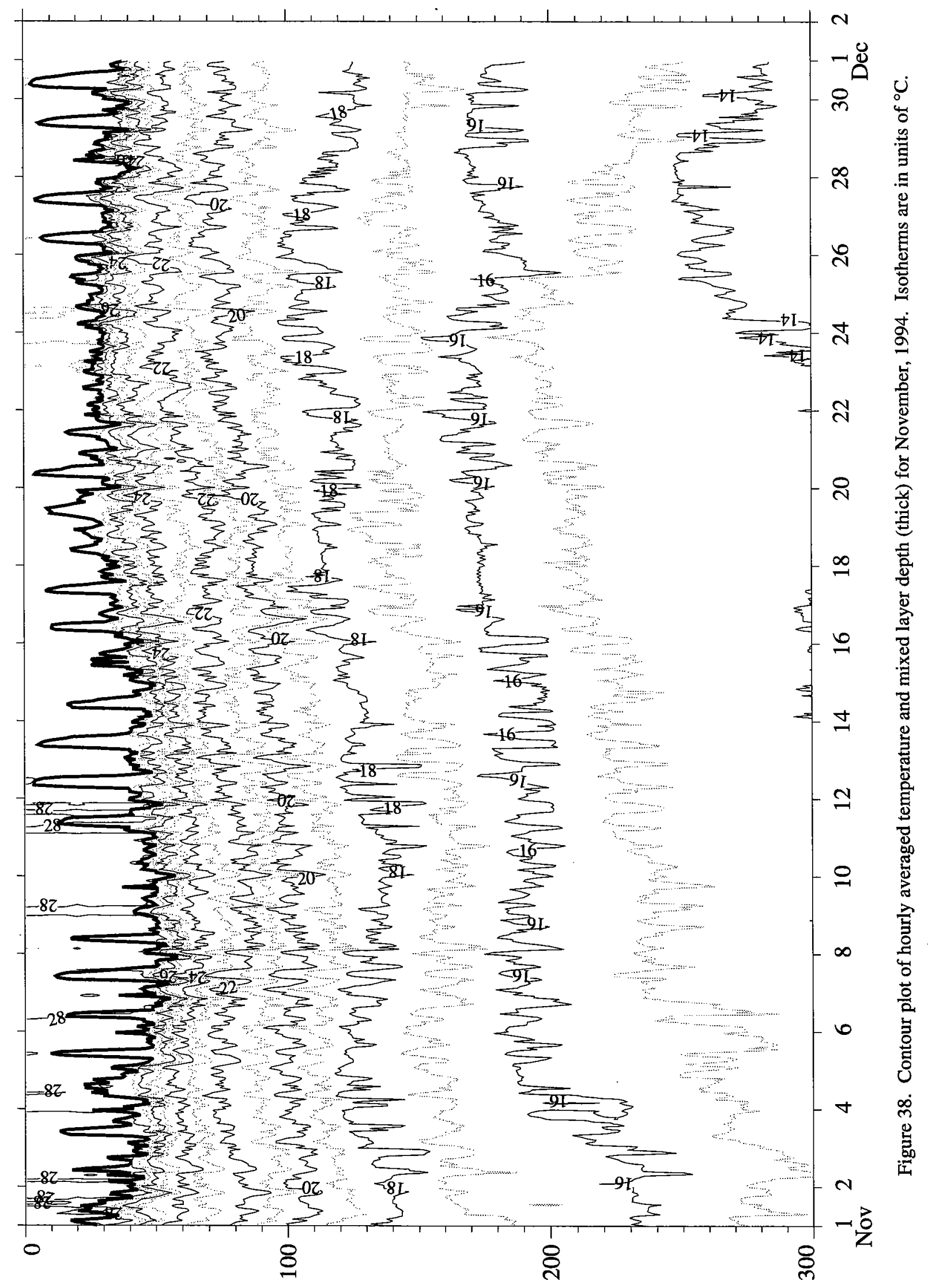

(ui) पIdəव 


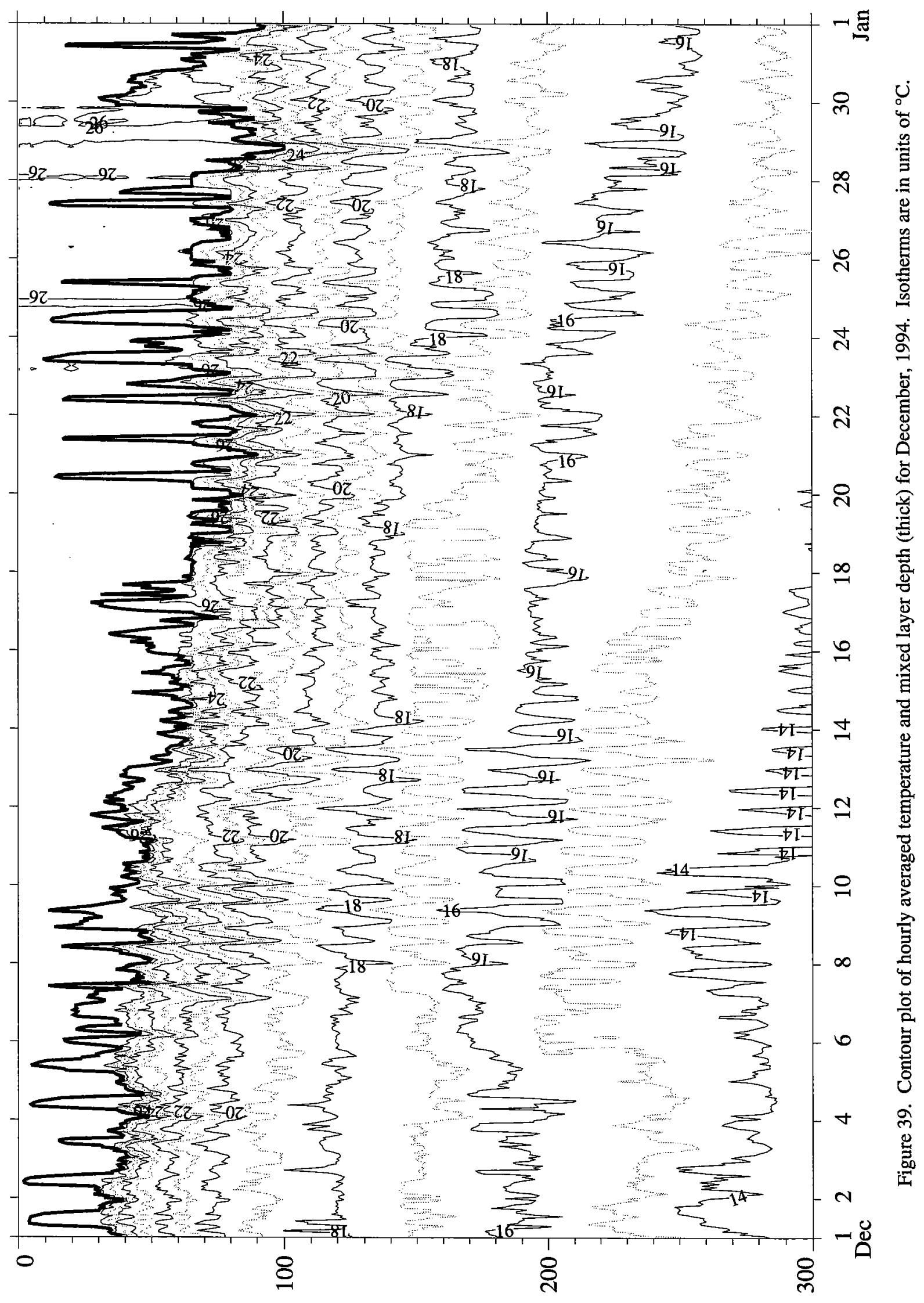

(u) पฺฺdəવ 


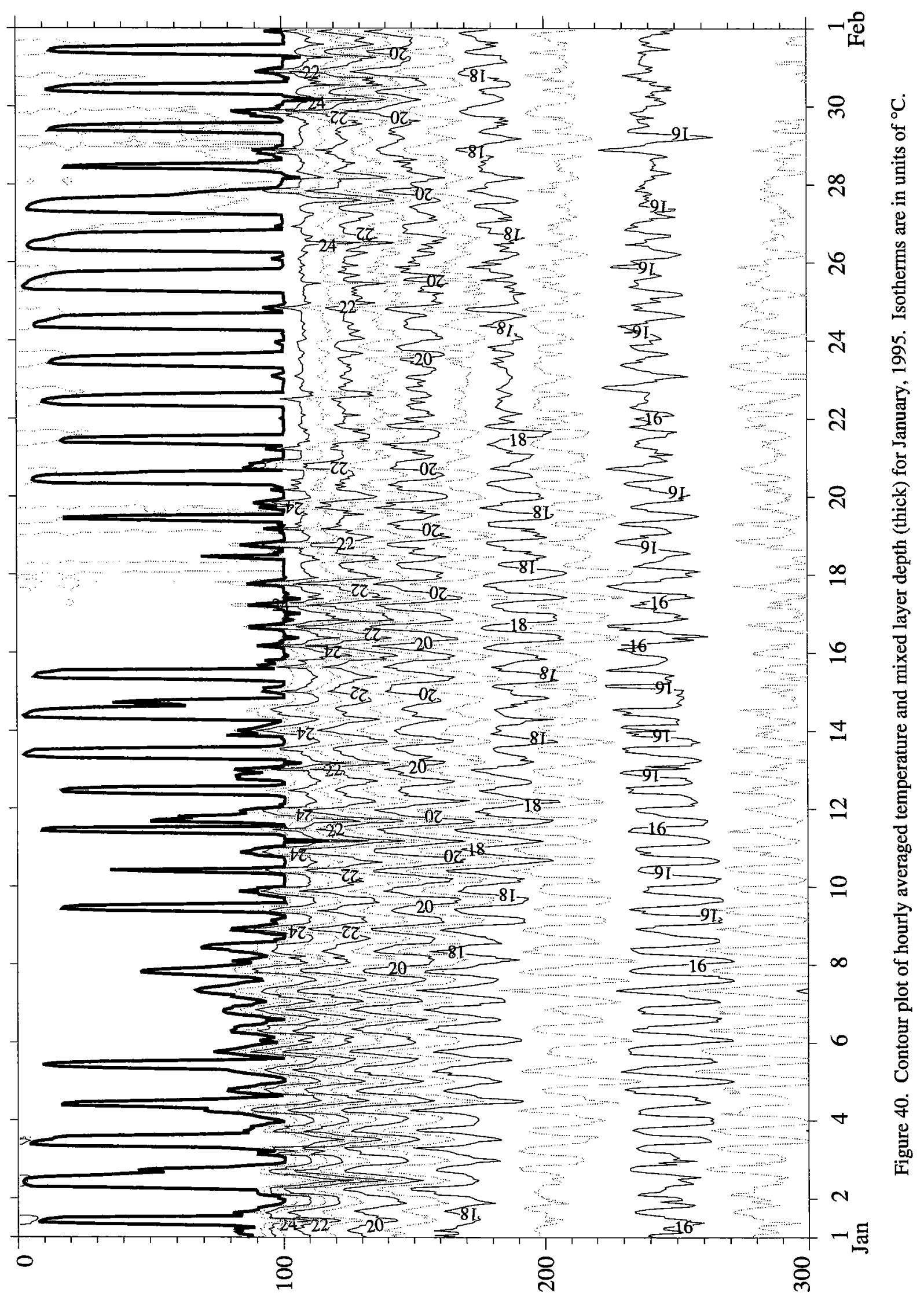

(ui) प1dəC 


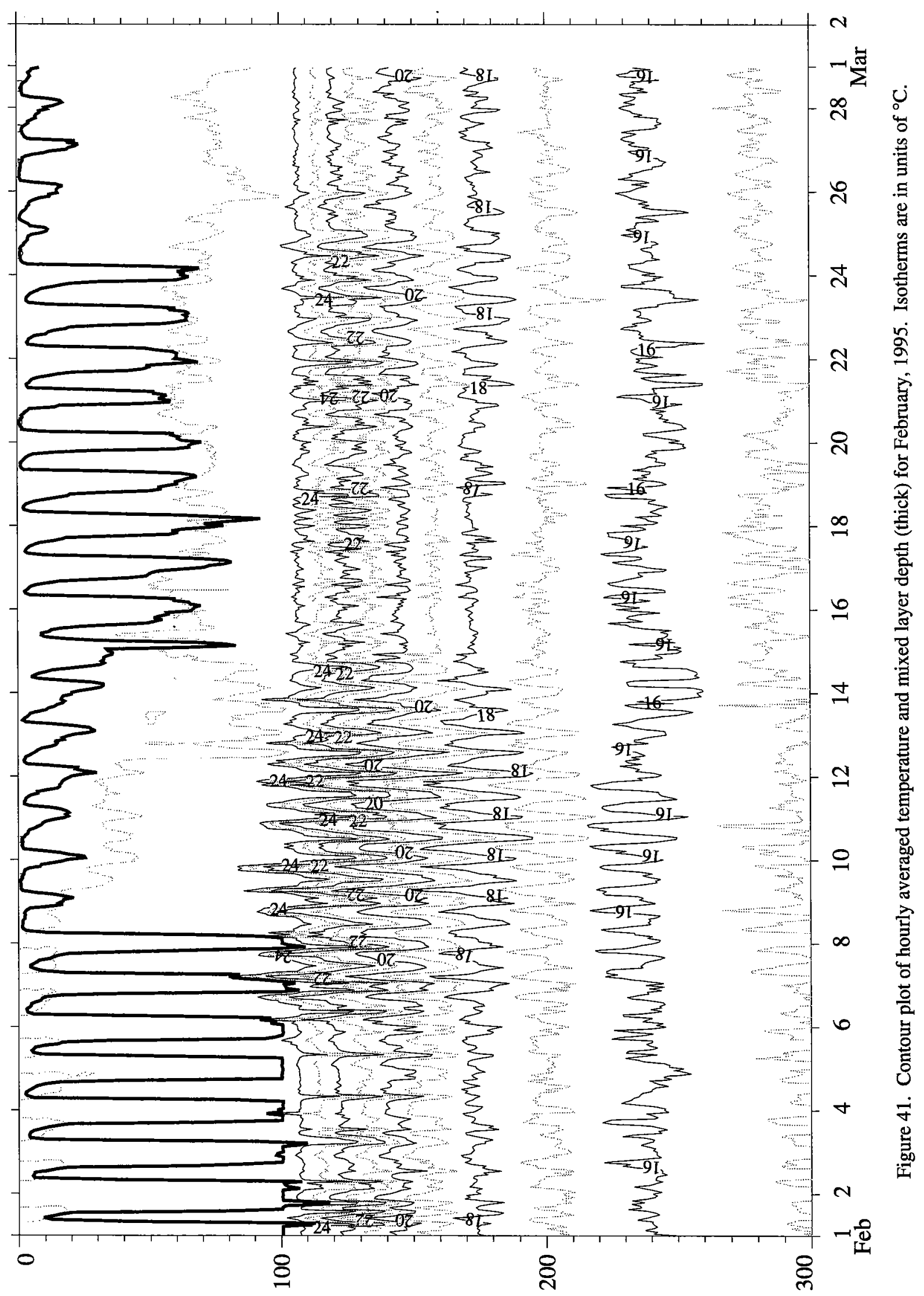

(u) чฺฺdəव 


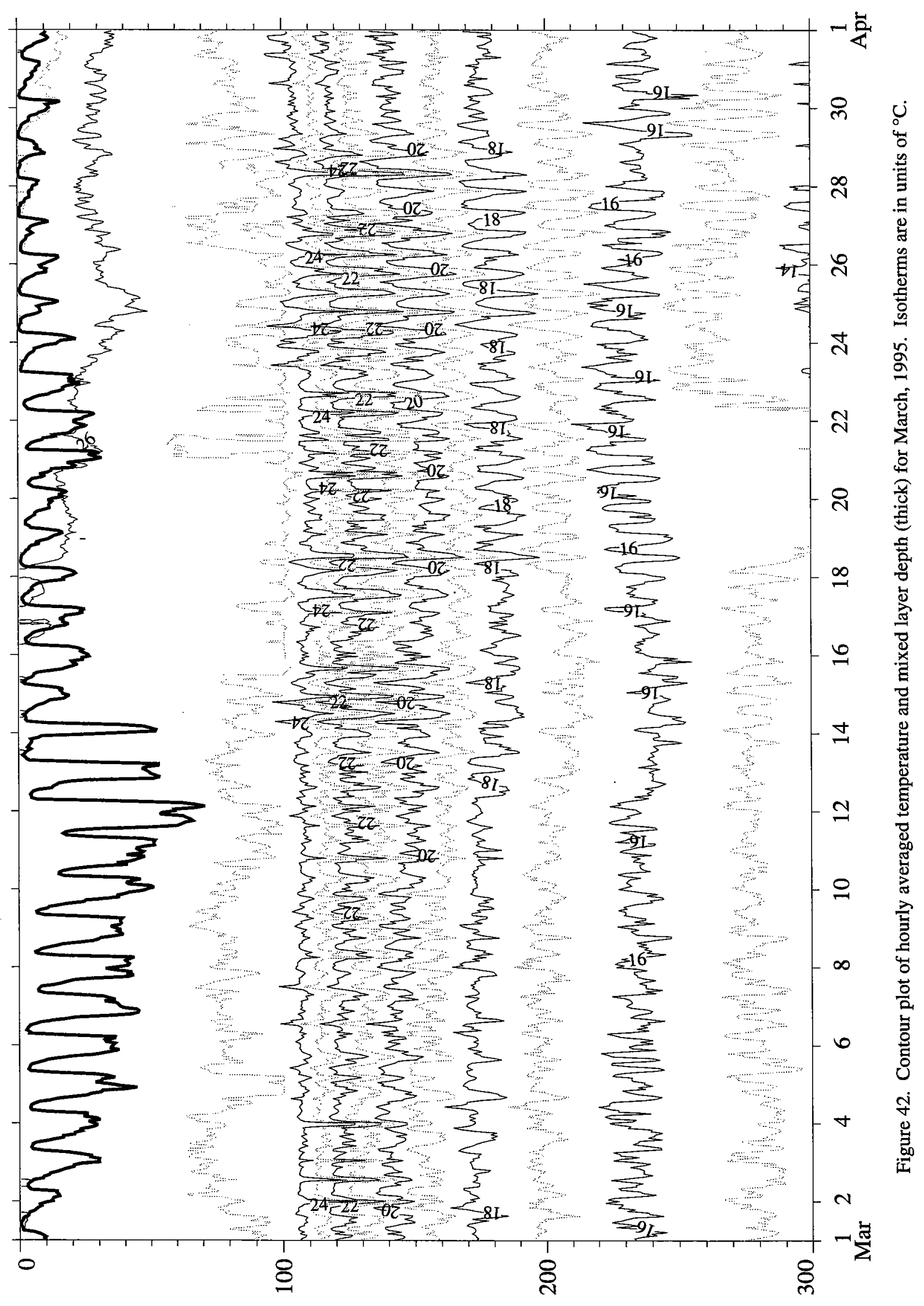

(ui) प१dә्व 


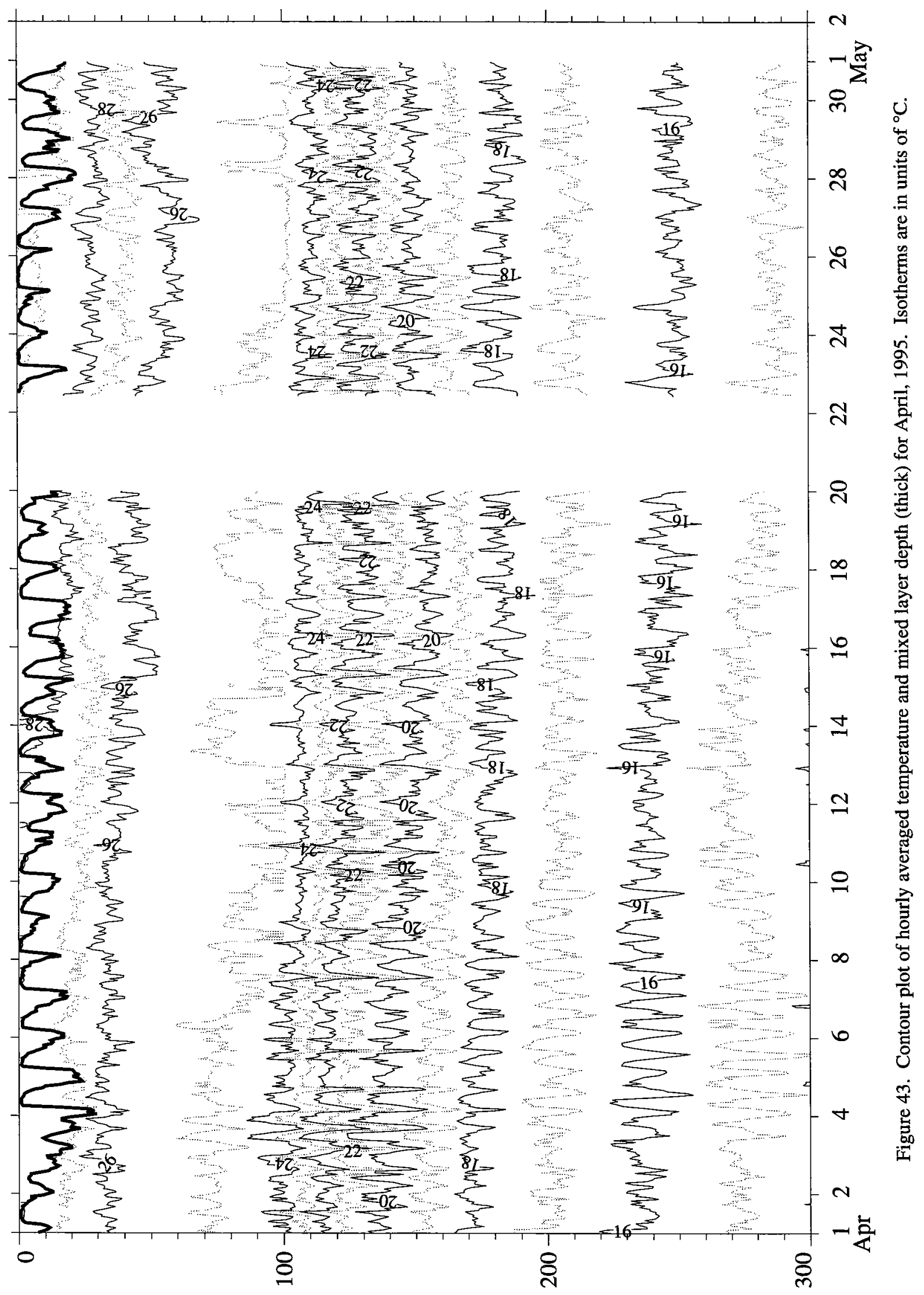

(u) प1dә्व 


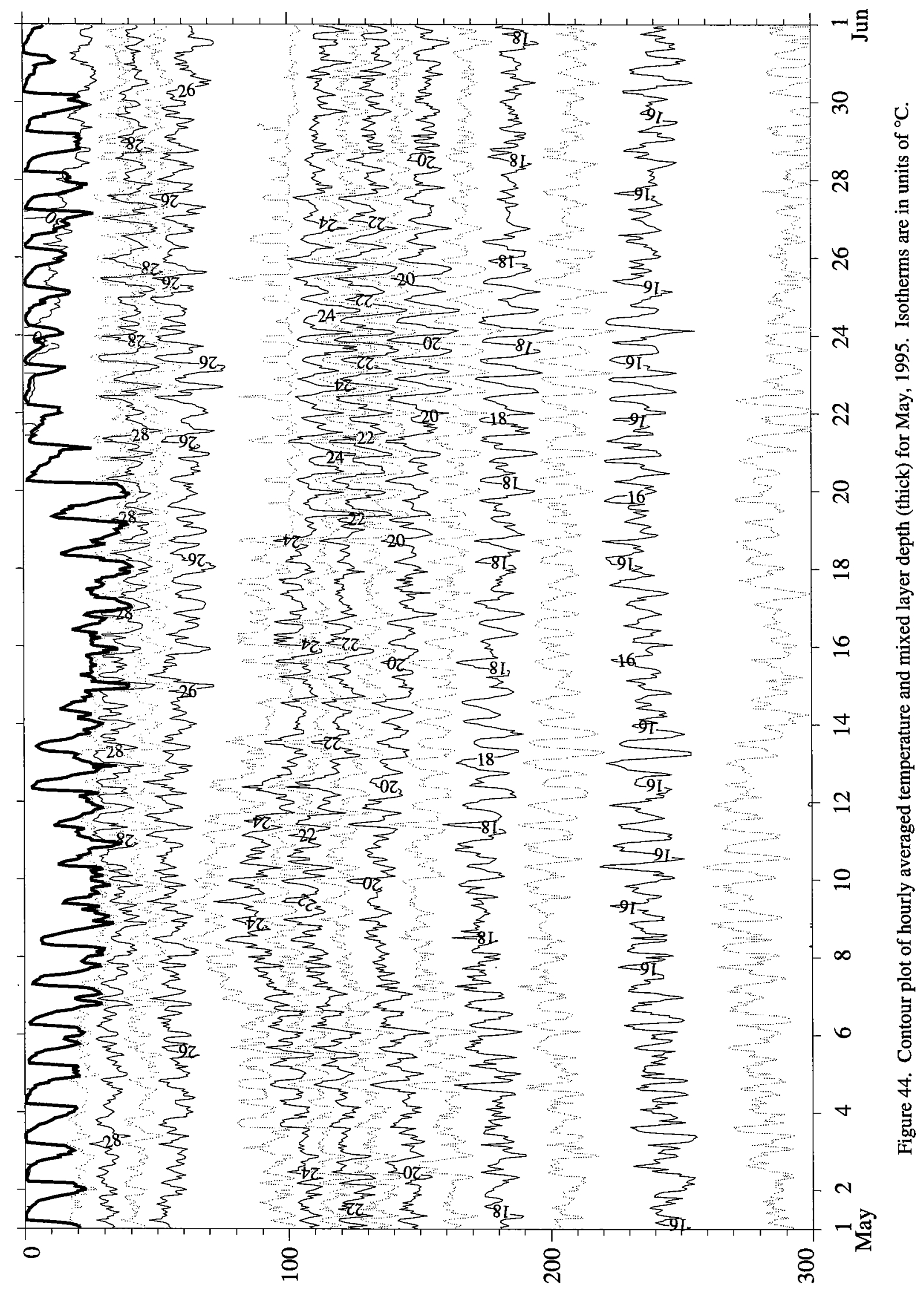

(u) प1dəव 


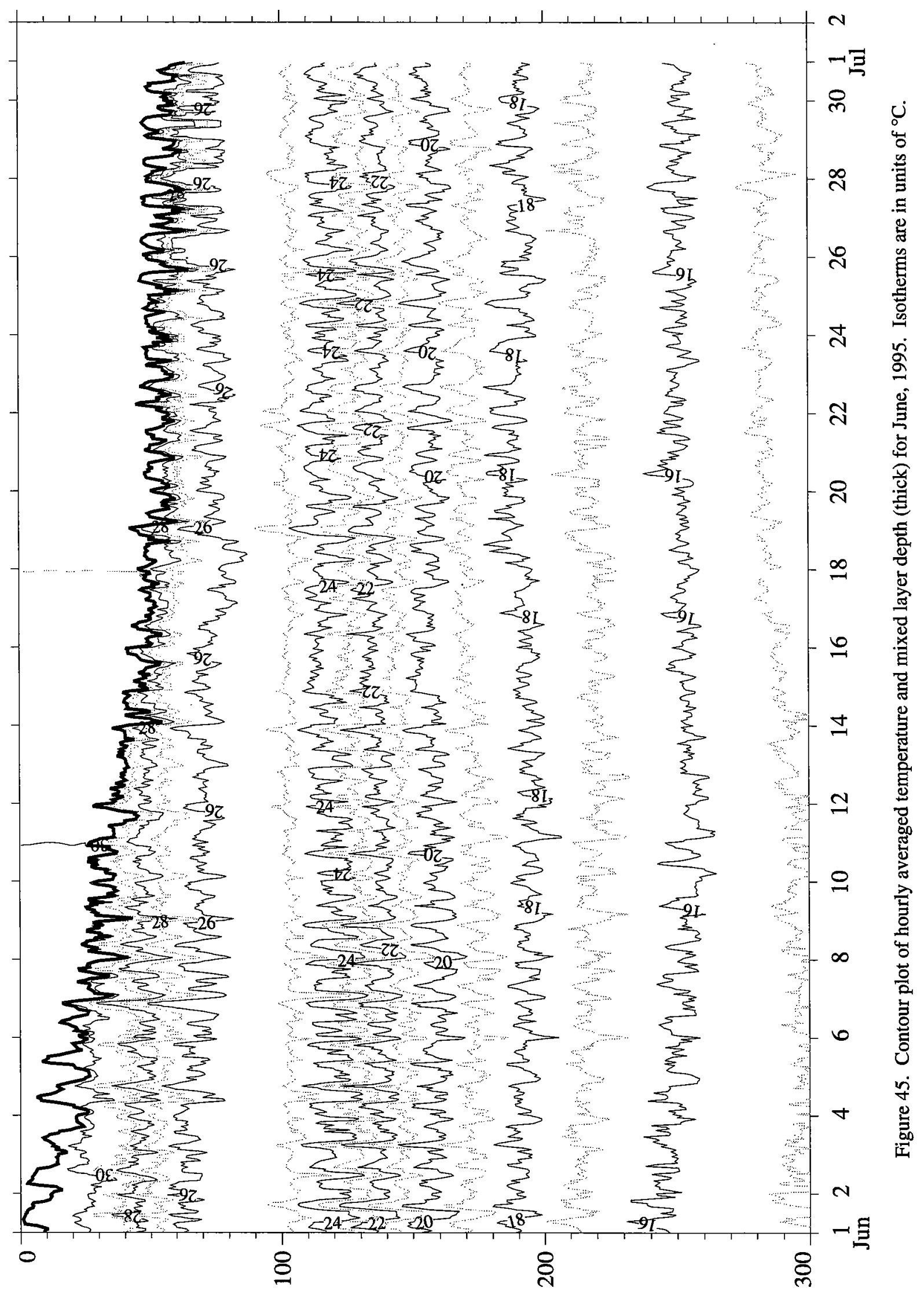

(u) प1də्व 


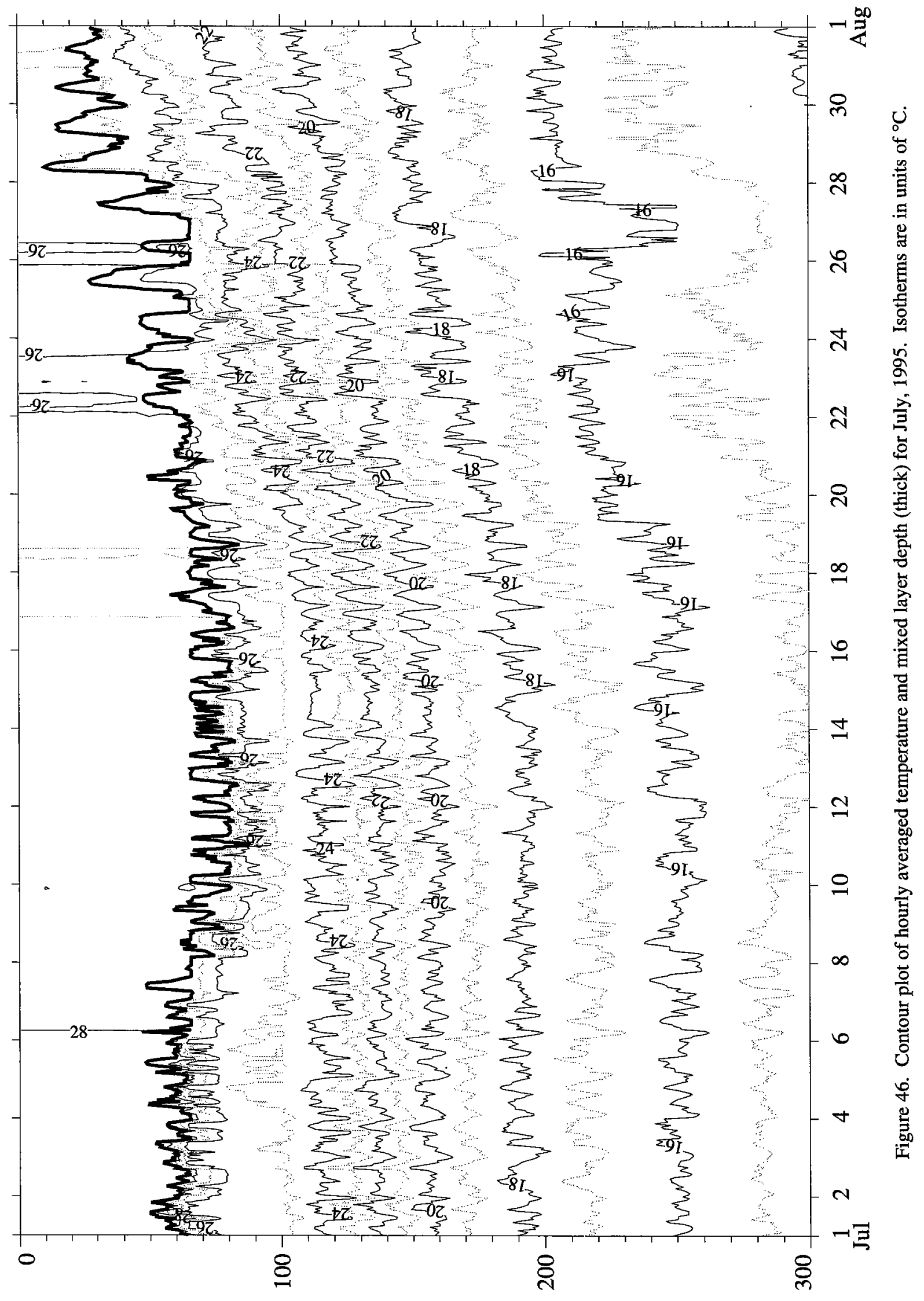

(u) प1dəव 


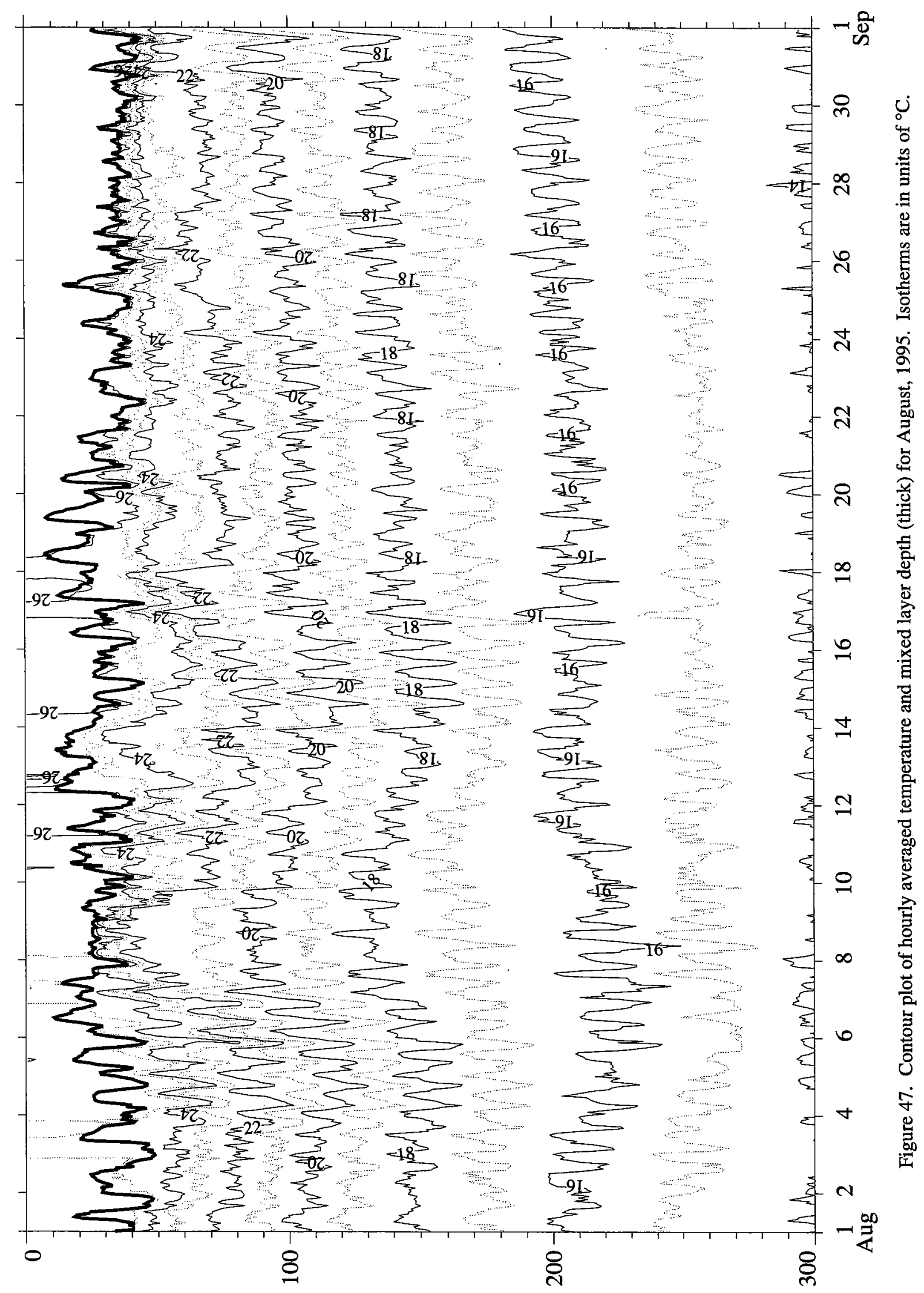

(u) प1dəव 


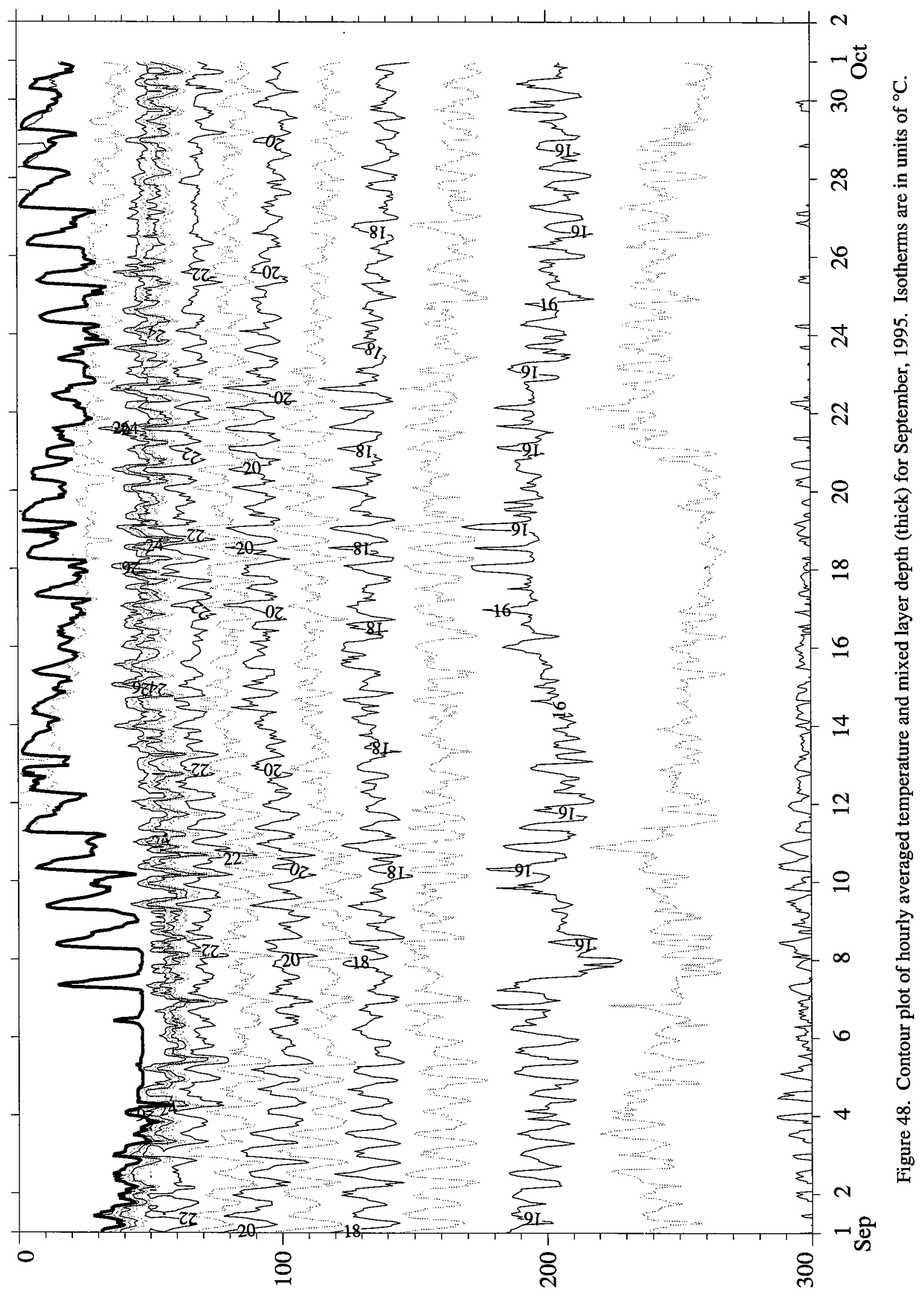

(u) पpdəव 


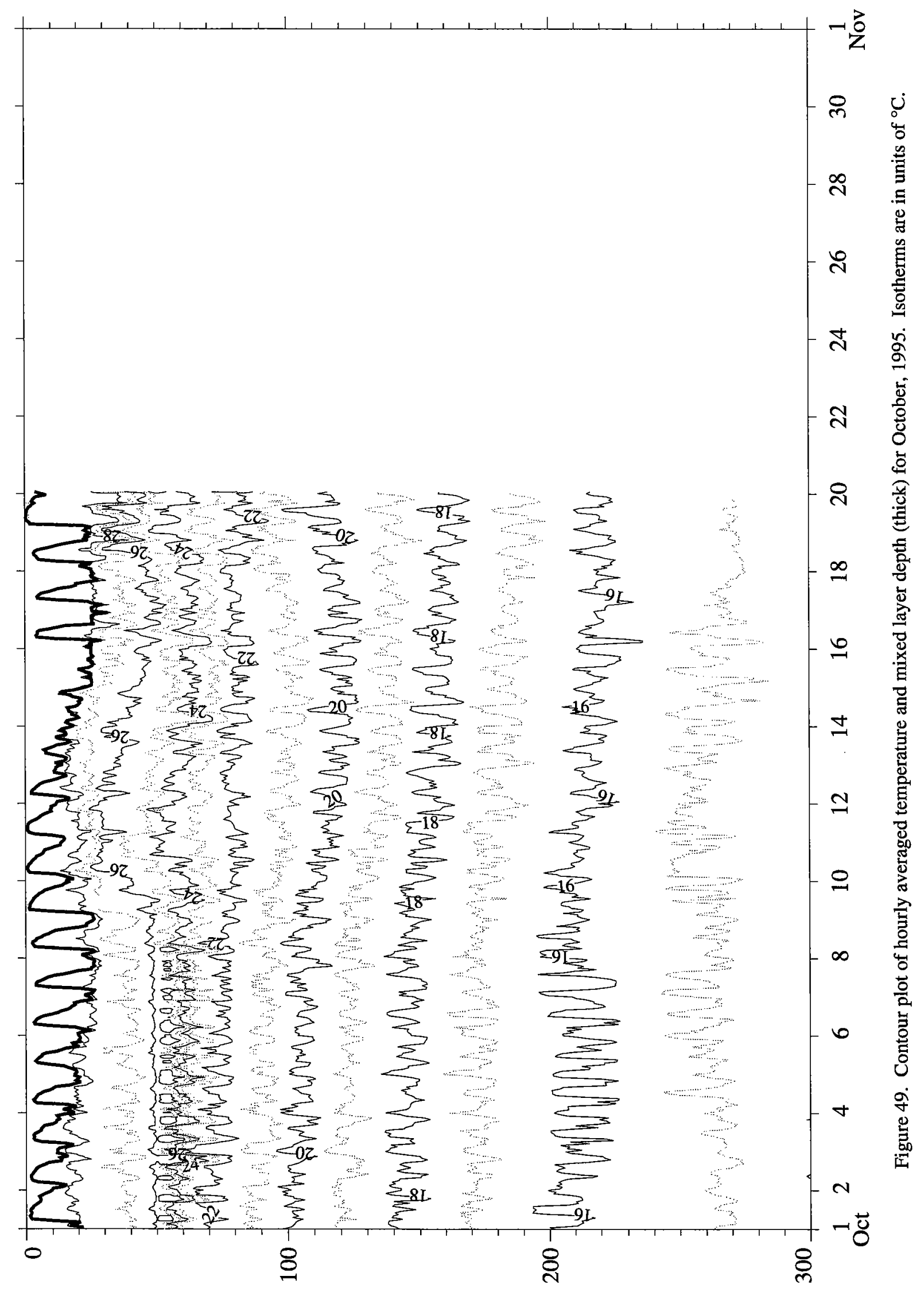

(ur) чрdәव 


\section{Oct Nov Dec Jan Feb Mar Apr May Jun Jul Aug Sep Oct Nov}

$5 \mathrm{~m}$

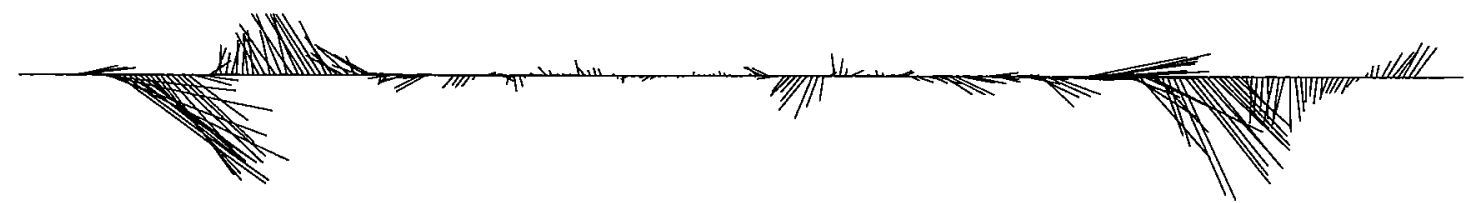

$10 \mathrm{~m}$

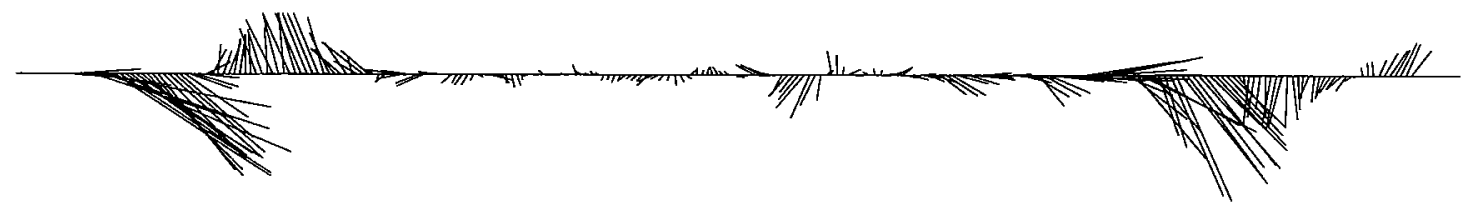

$15 \mathrm{~m}$

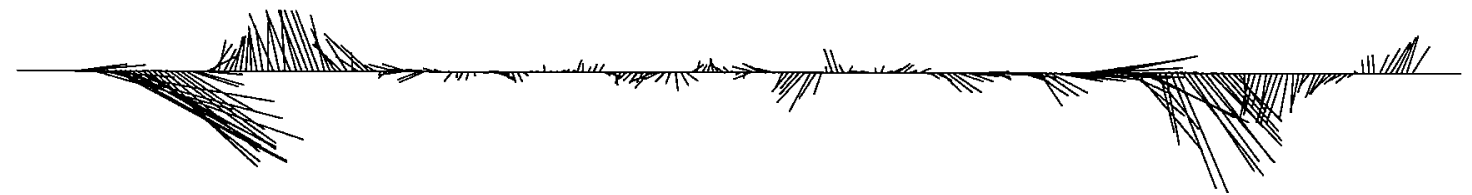

$25 \mathrm{~m}$

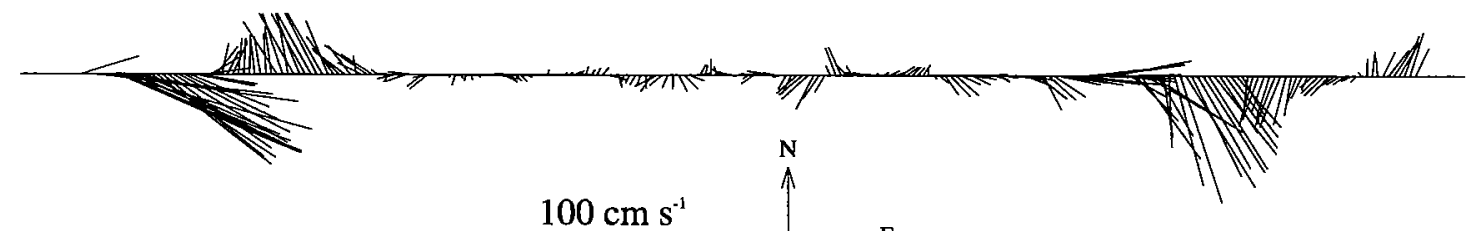

$35 \mathrm{~m}$

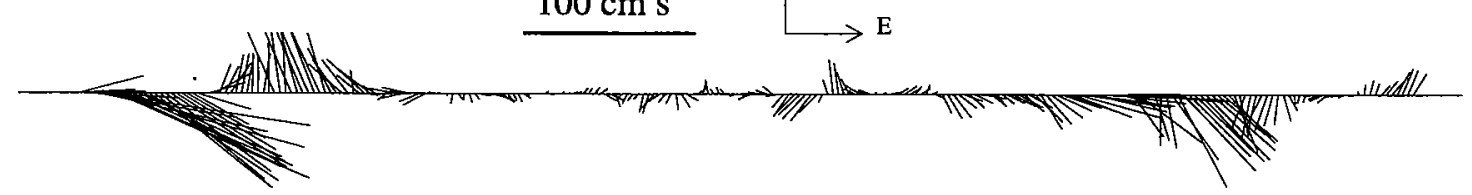

$45 \mathrm{~m}$

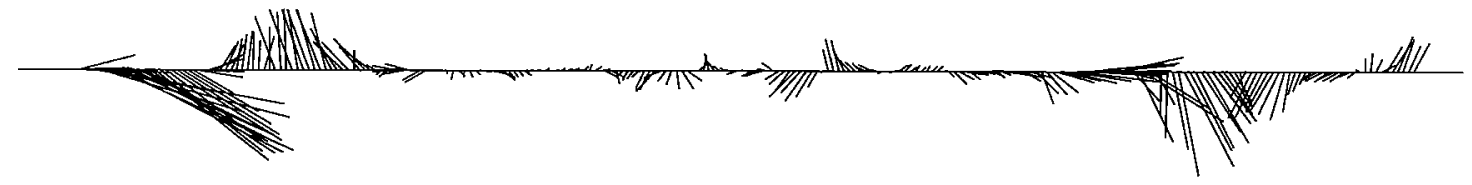

$55 \mathrm{~m}$

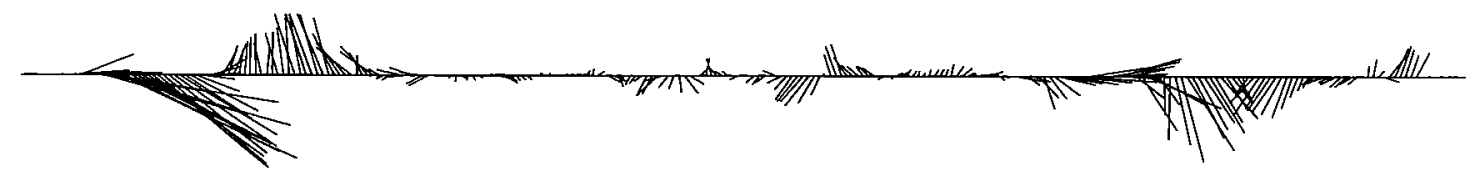

$65 \mathrm{~m}$

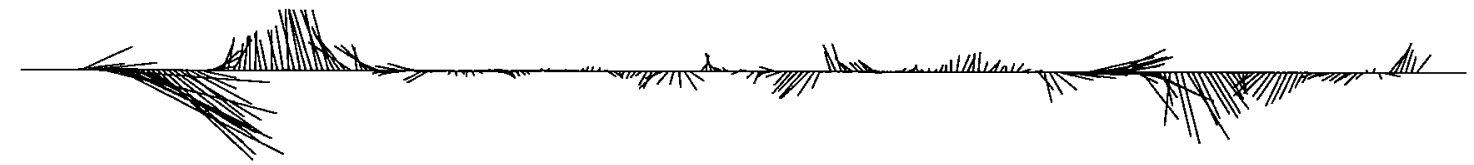

$80 \mathrm{~m}$

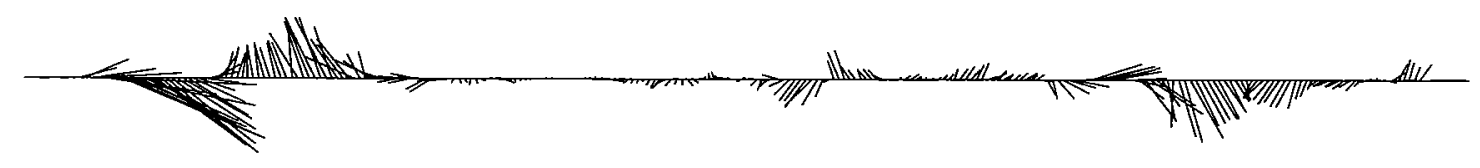

Oct
1994

Figure 50. VMCM and MVMS 36 hour vector averaged velocity from the WHOI mooring. 
Oct Nov Dec Jan Feb Mar Apr May Jun Jul Aug Sep Oct Nov

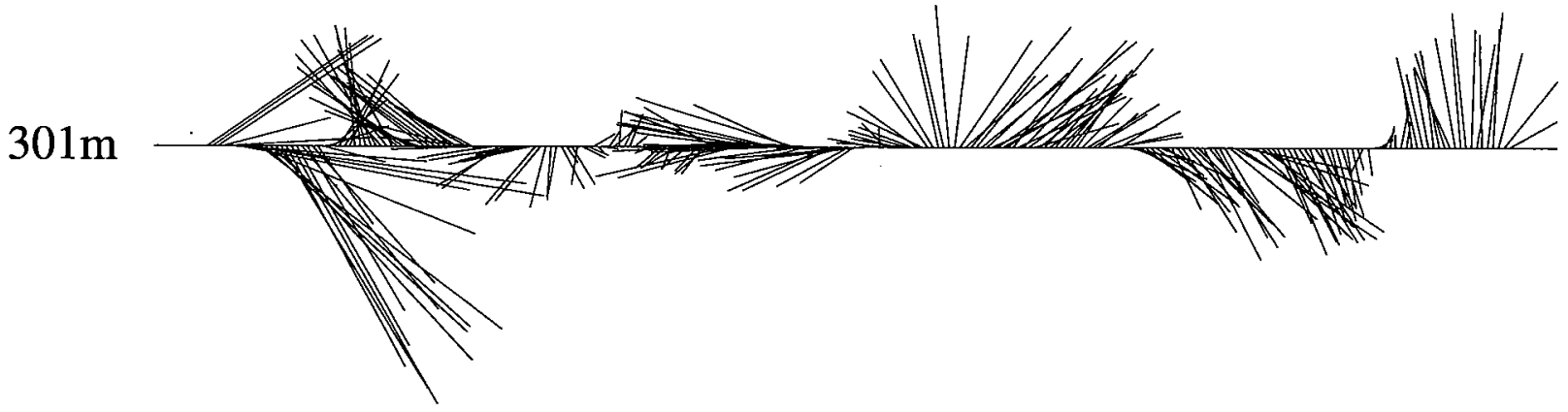

$492 \mathrm{~m}$

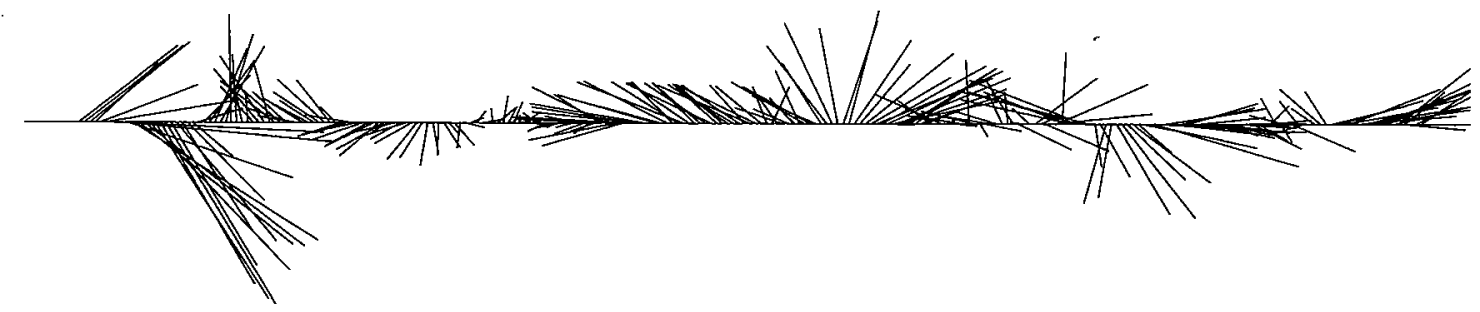

$749 m$

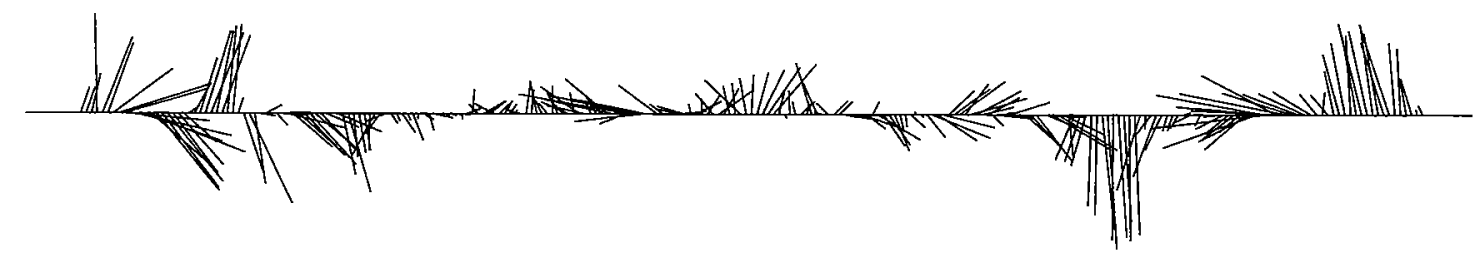

Oct Nov Dec Jan Feb Mar Apr May Jun Jul Aug Sep Oct Nov

Figure 51. VMCM 36 hour vector averaged velocity from the UW Southeast mooring. 


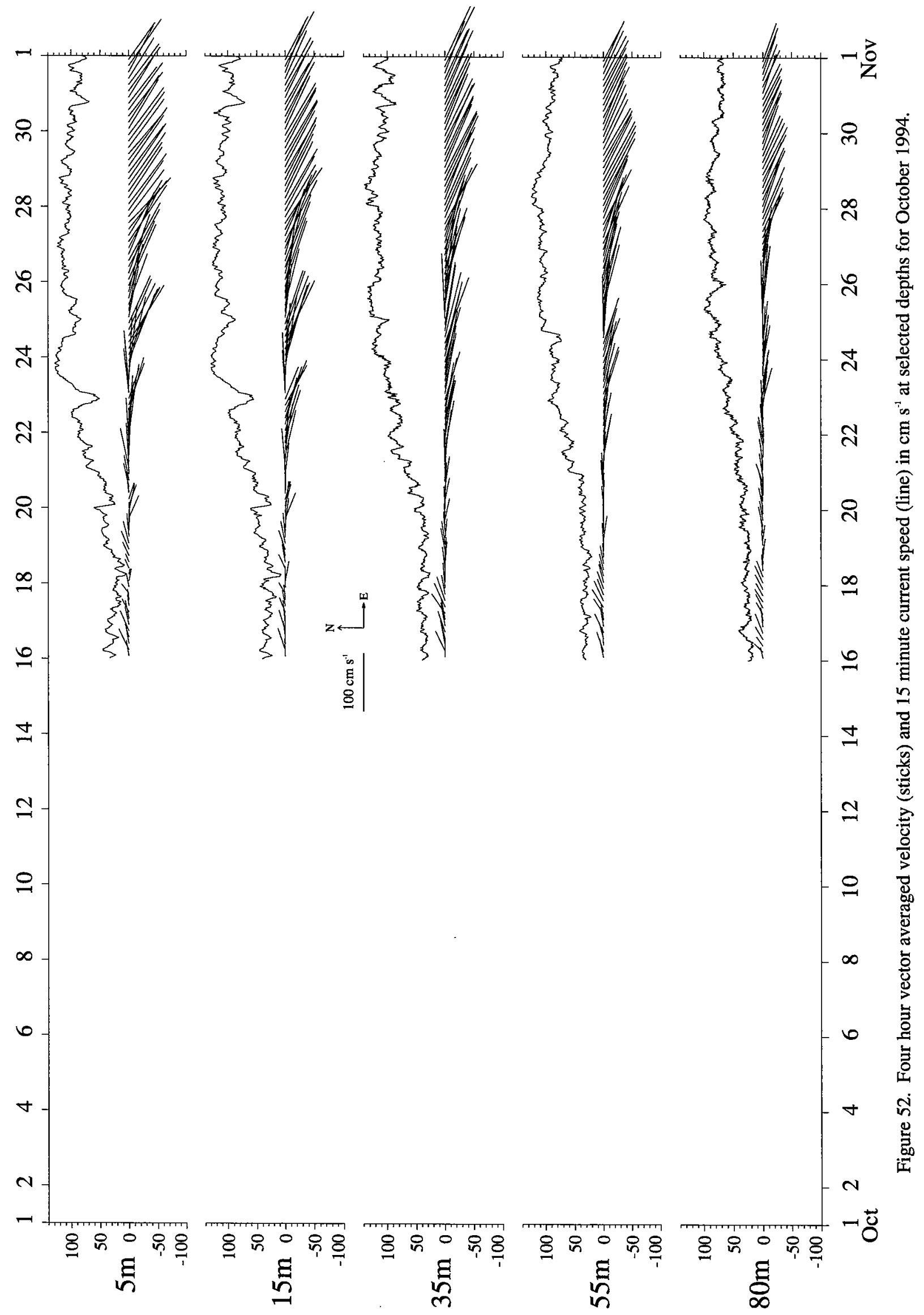




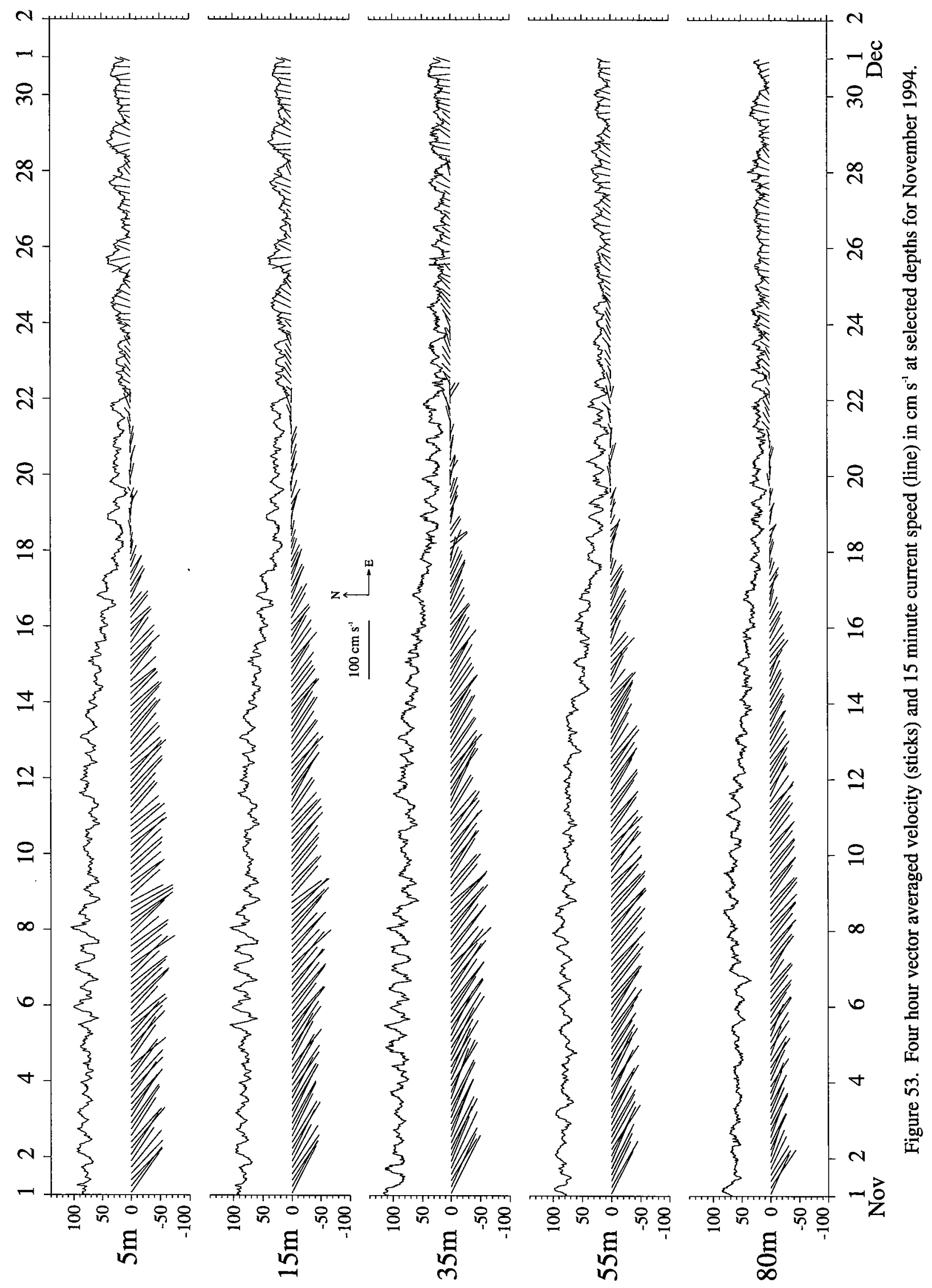




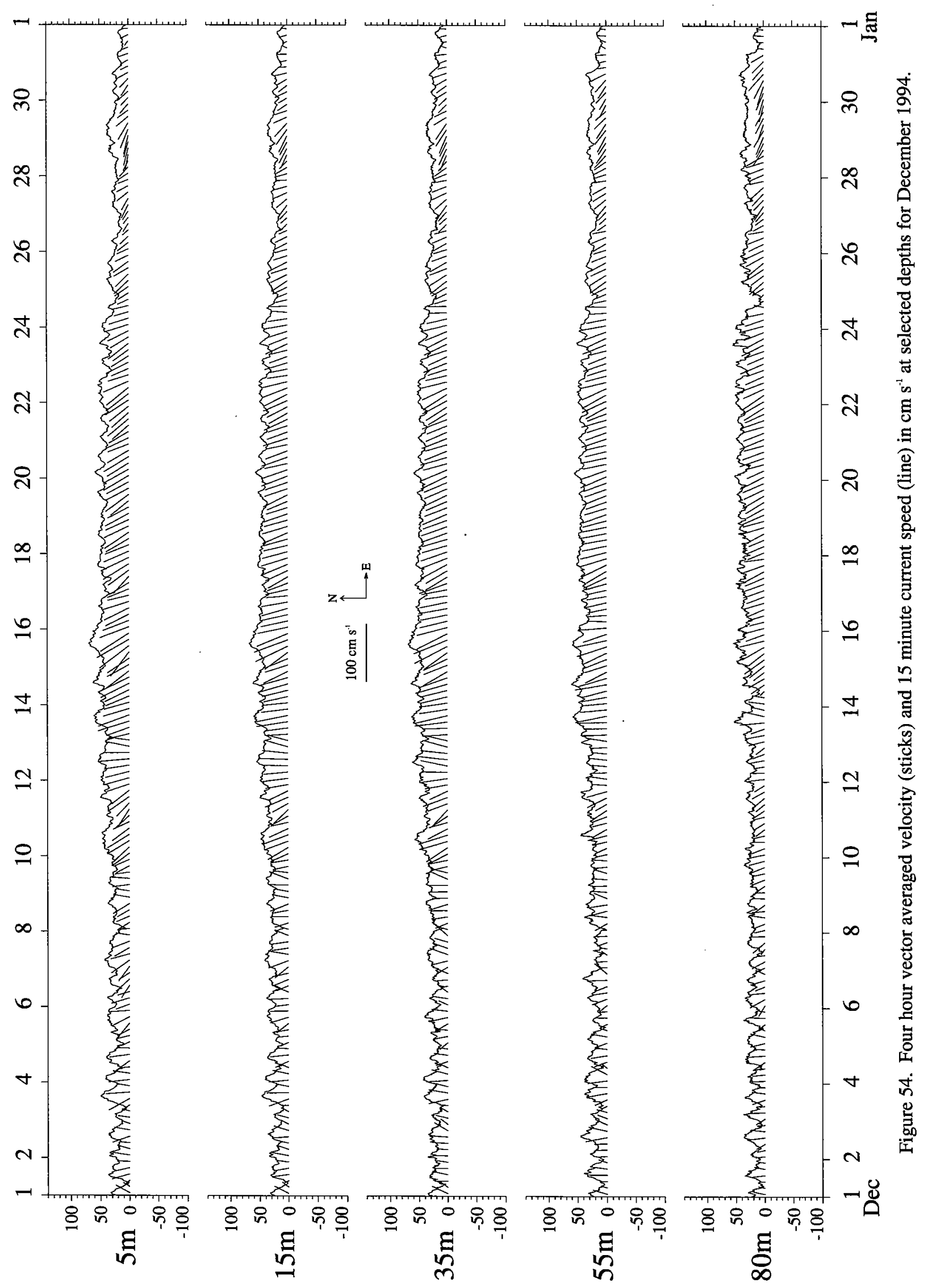




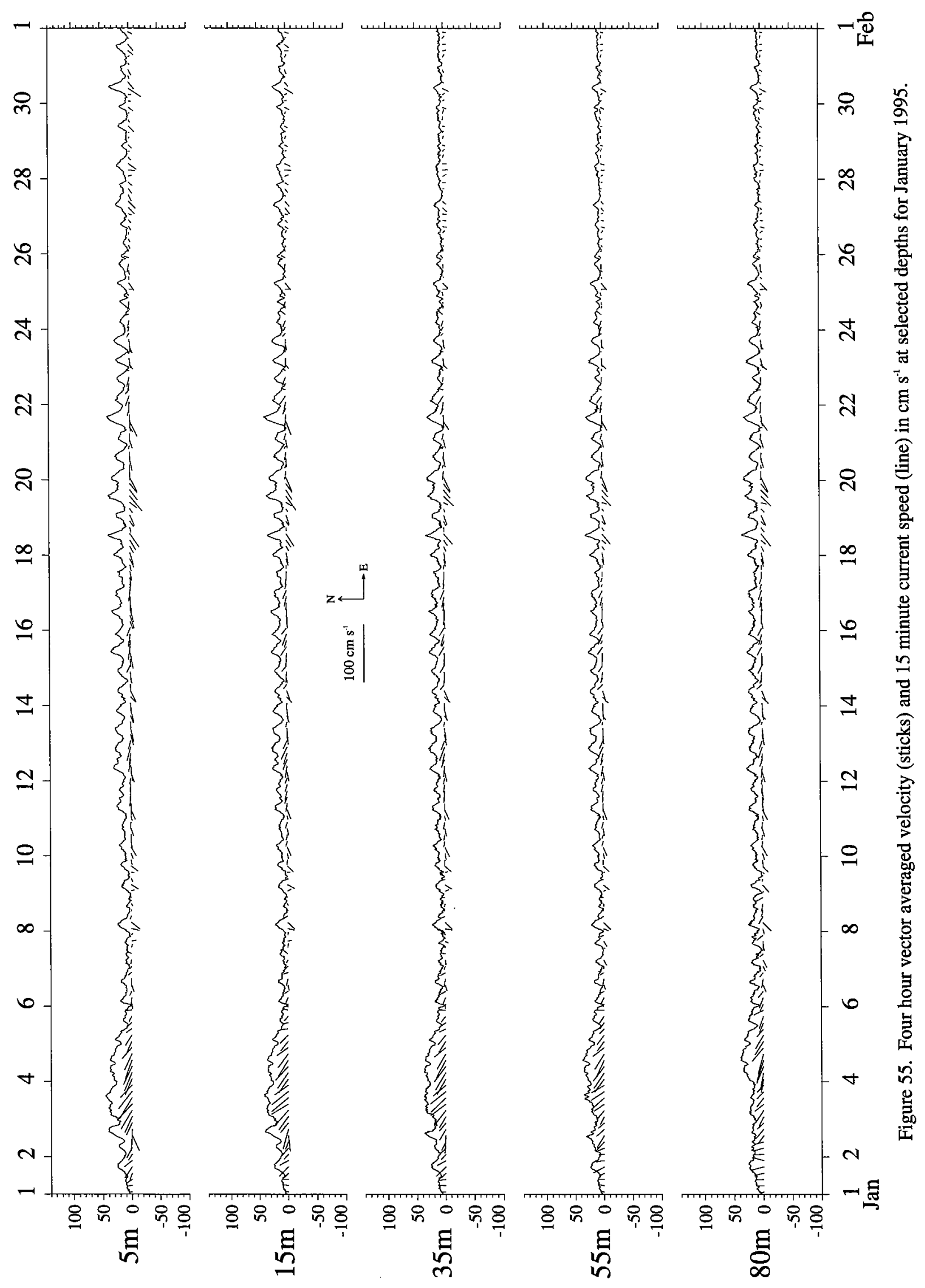




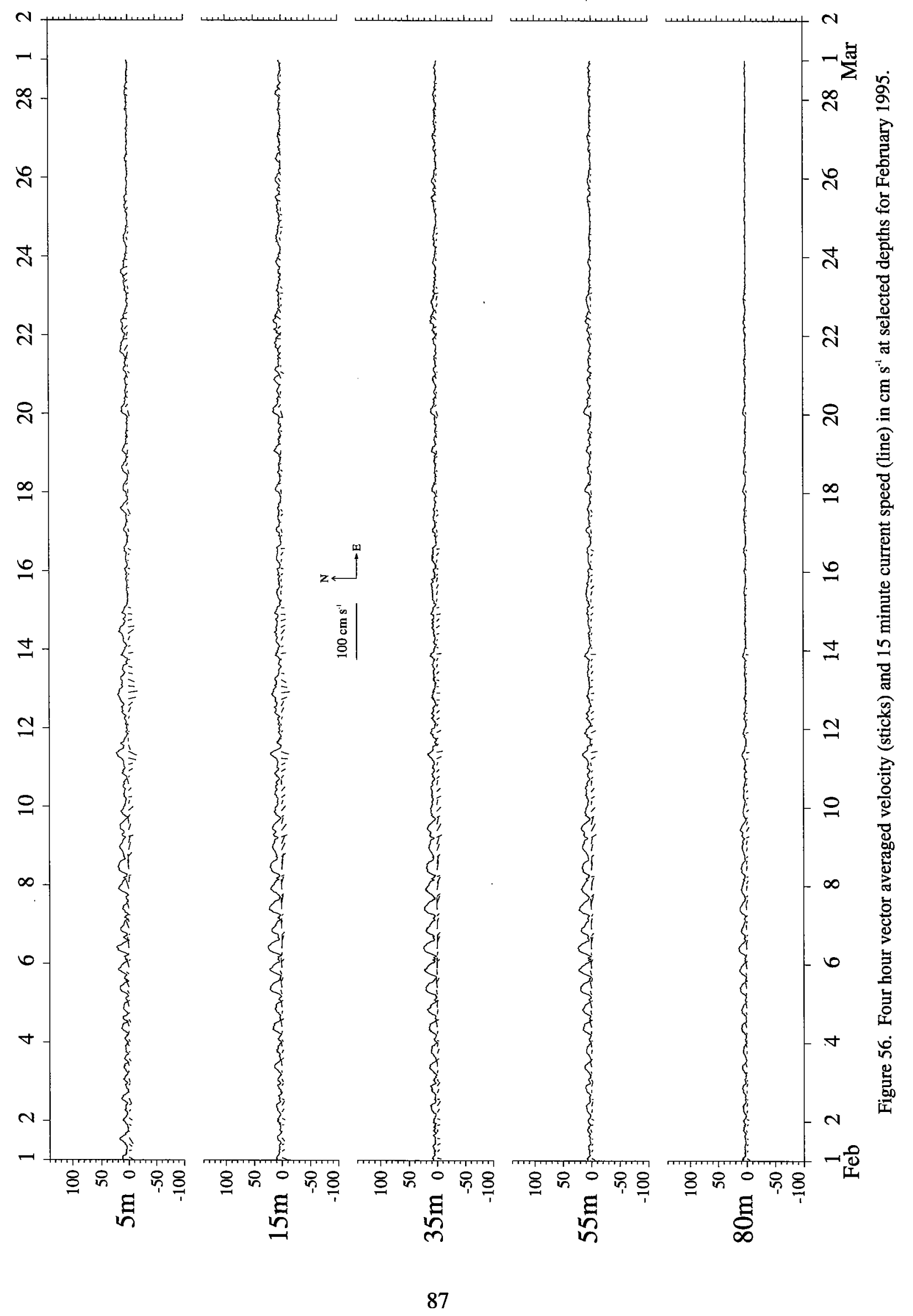




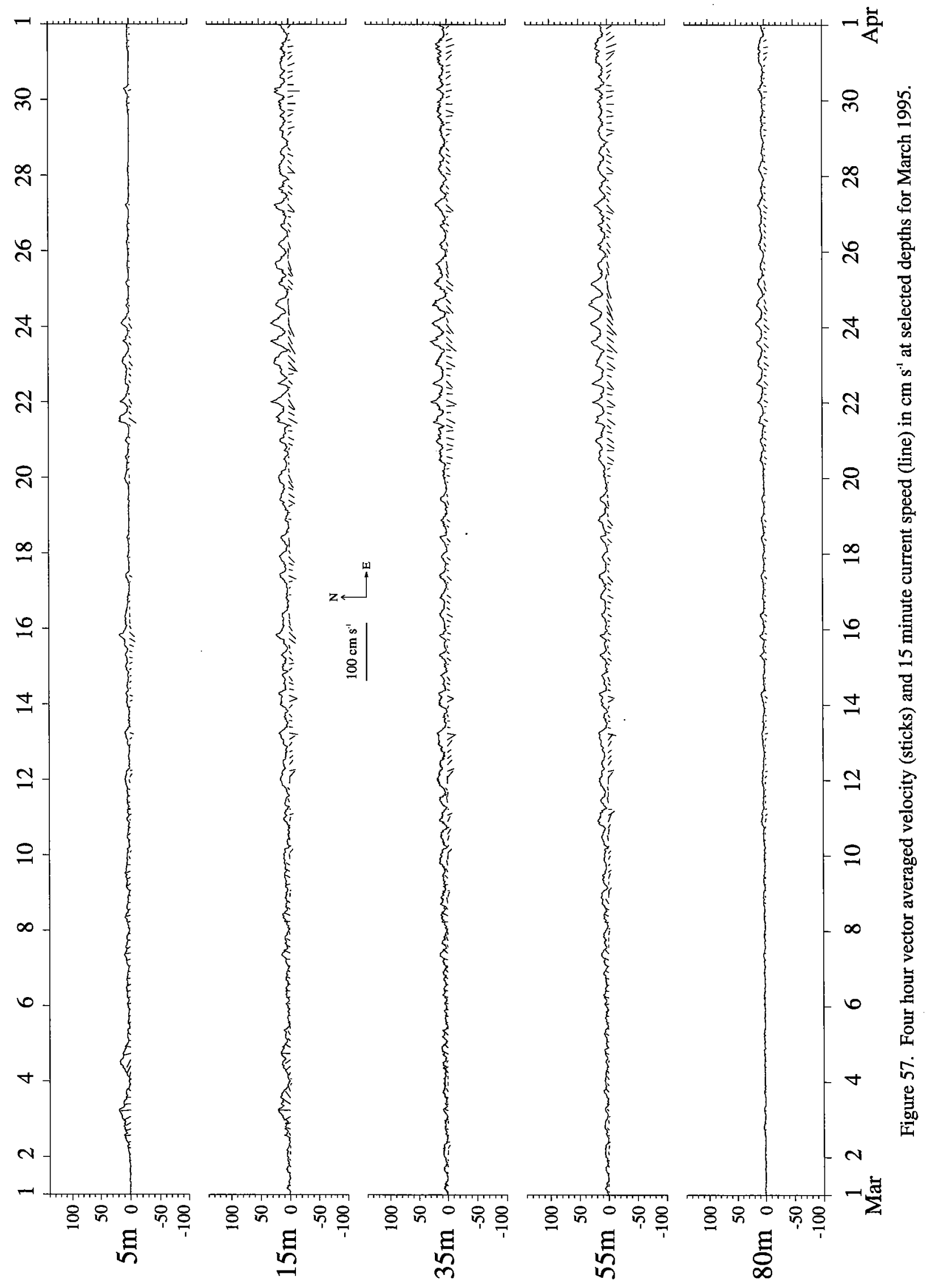




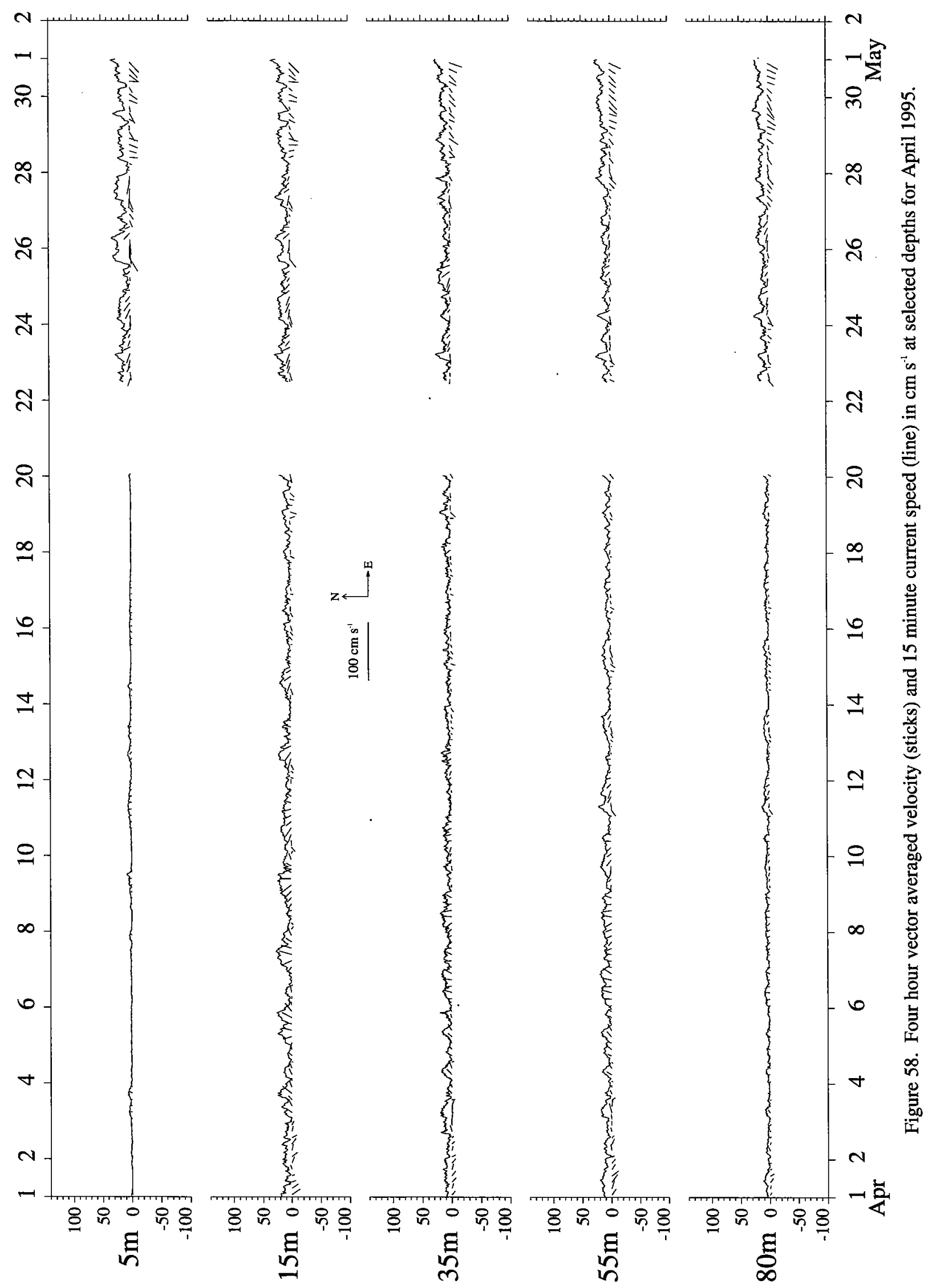




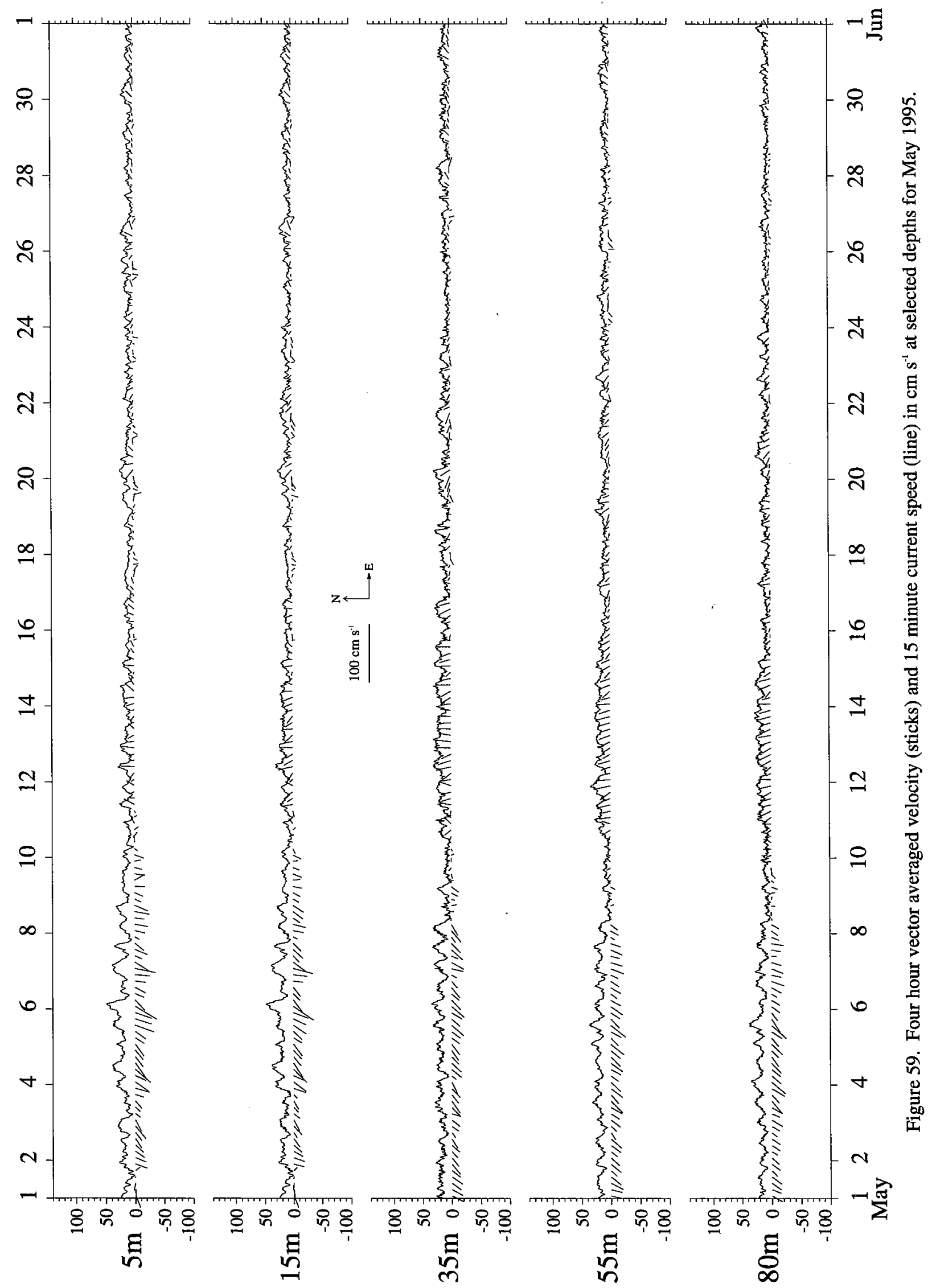




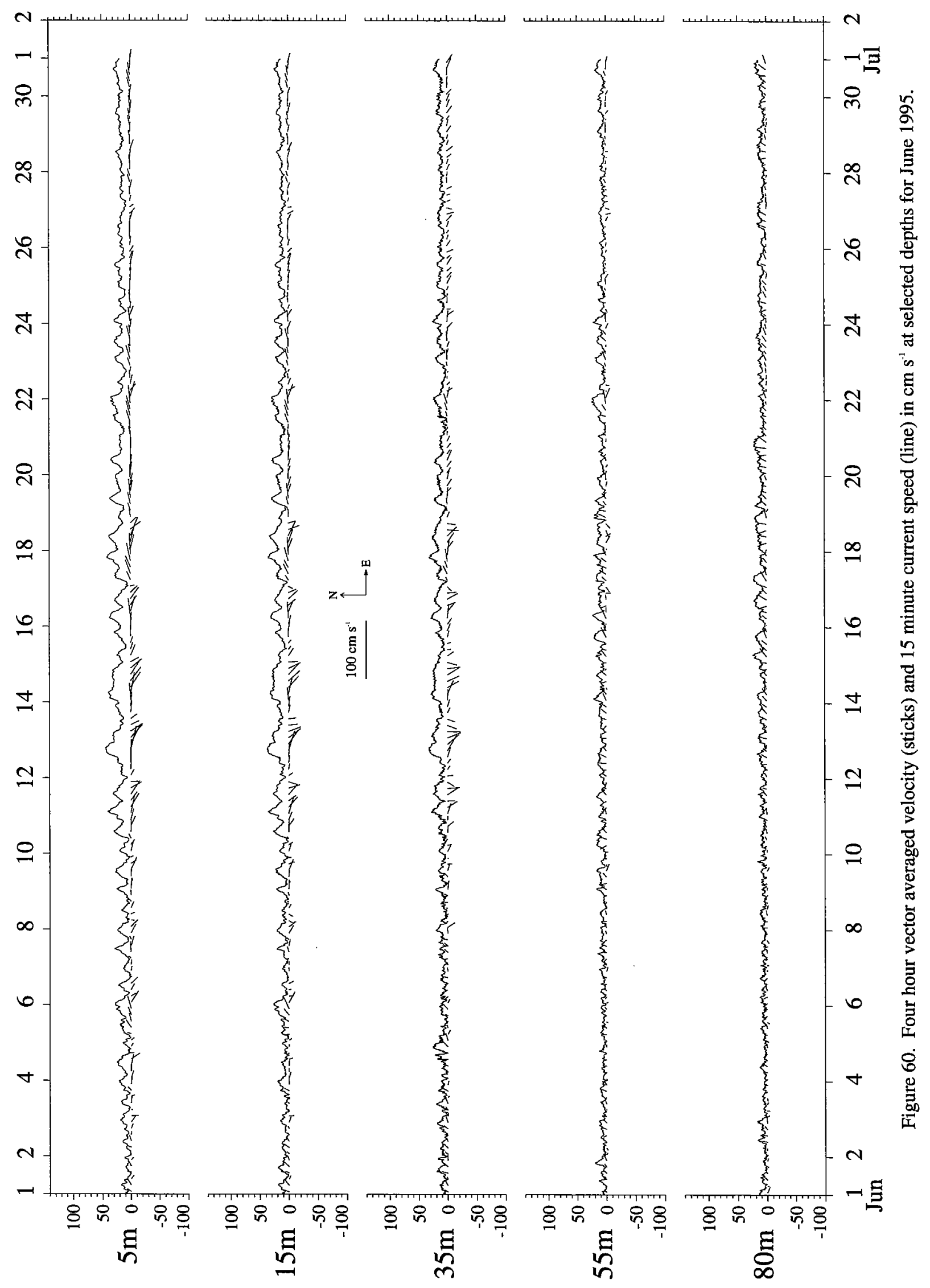




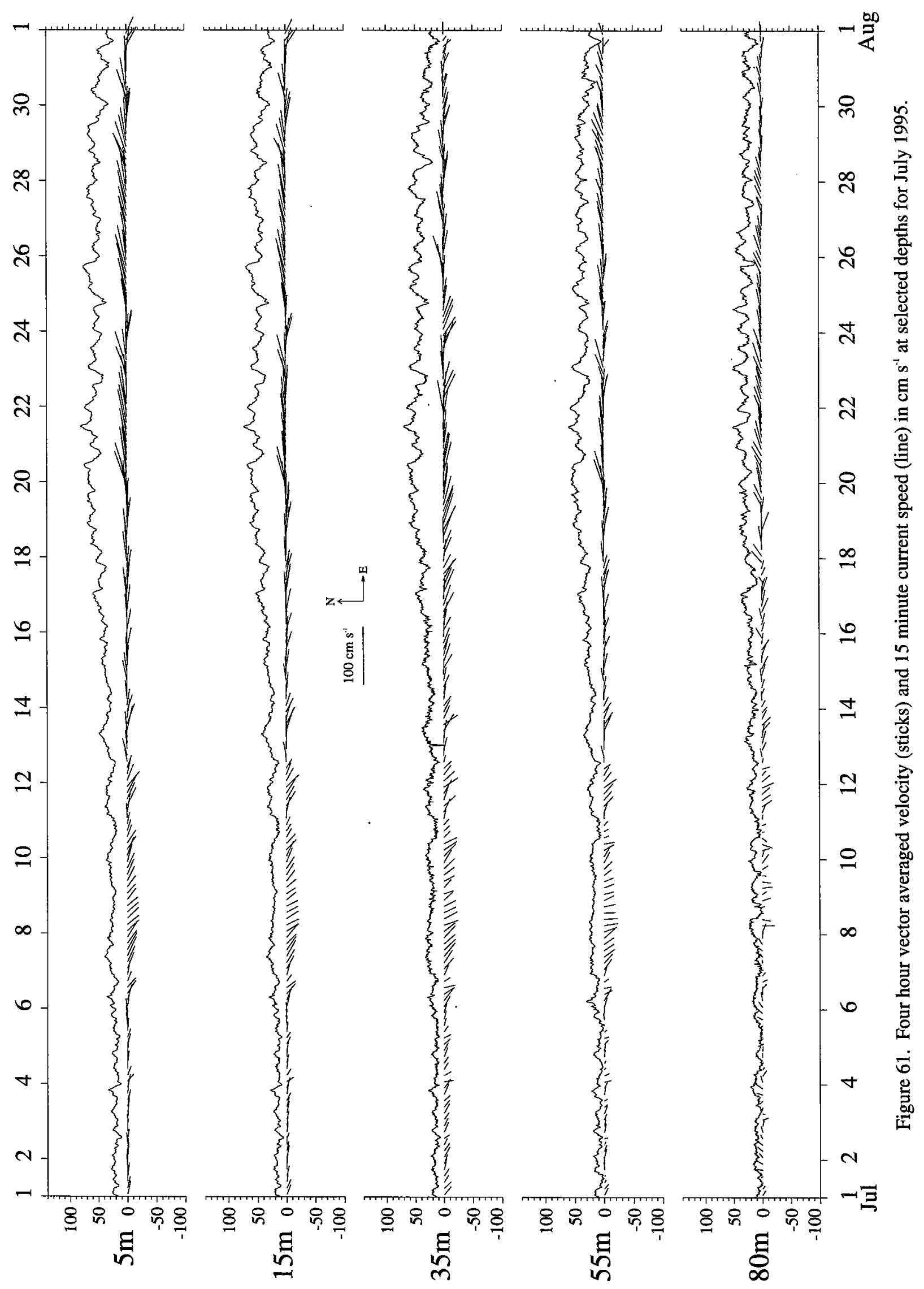




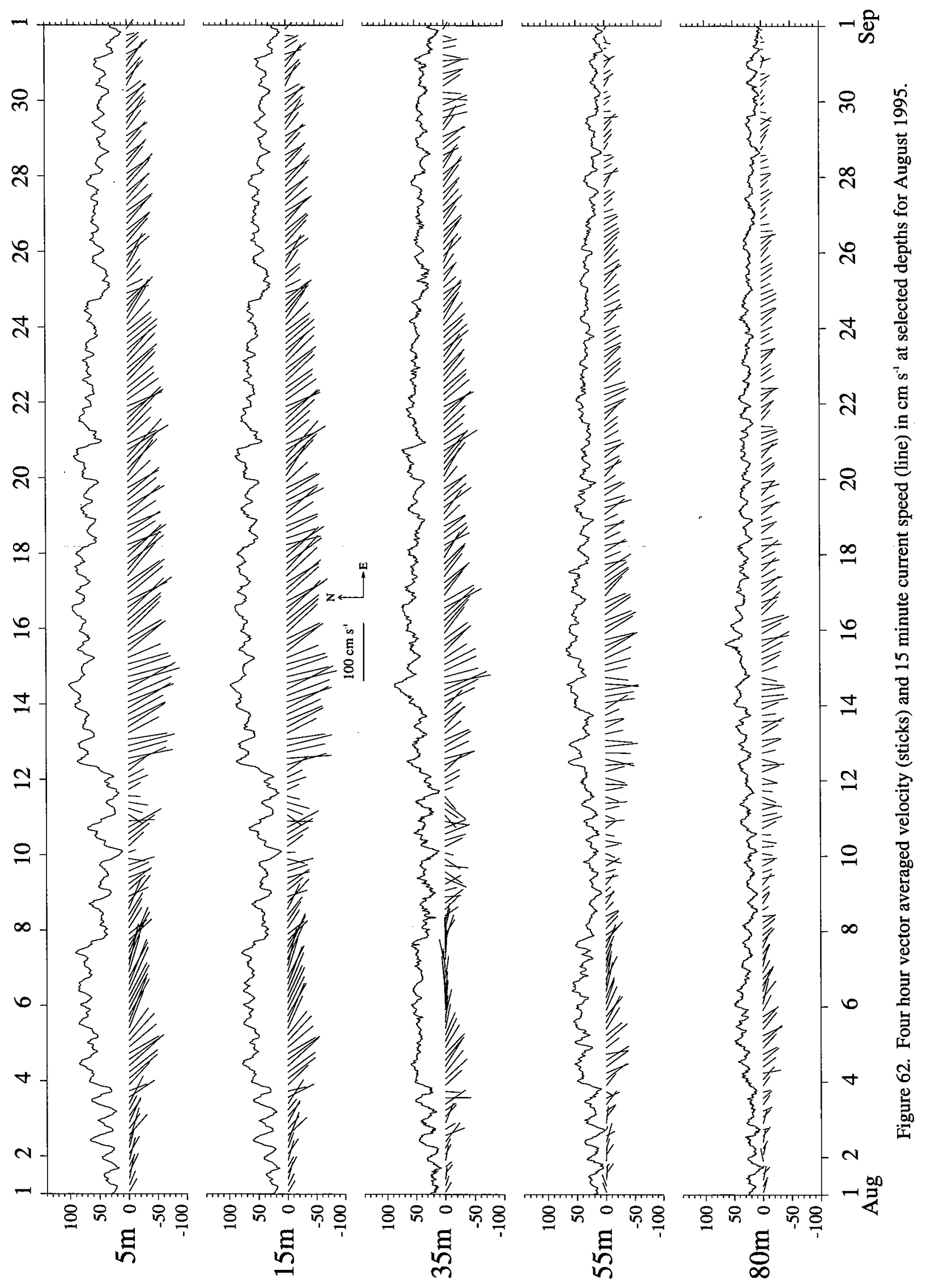




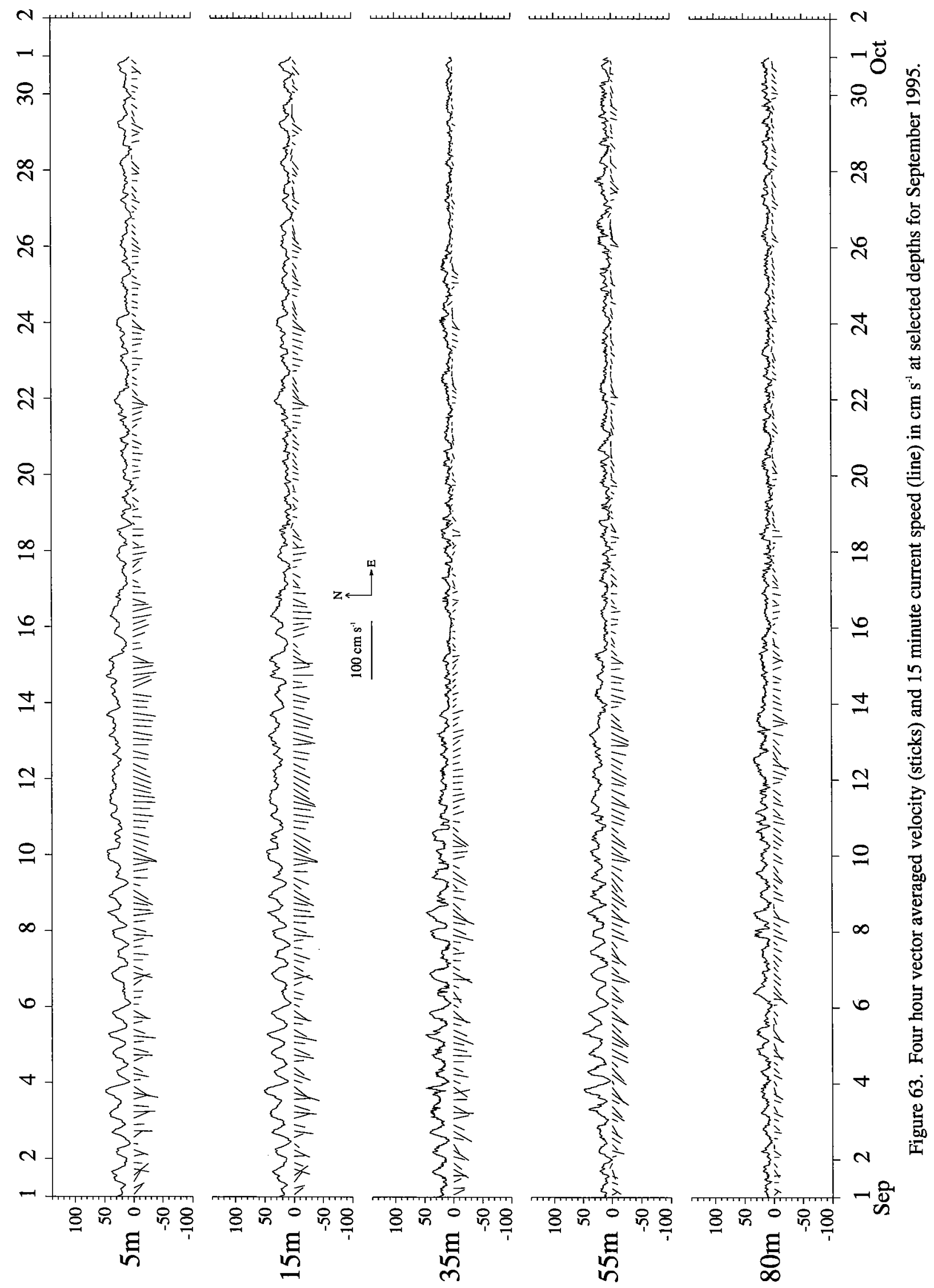




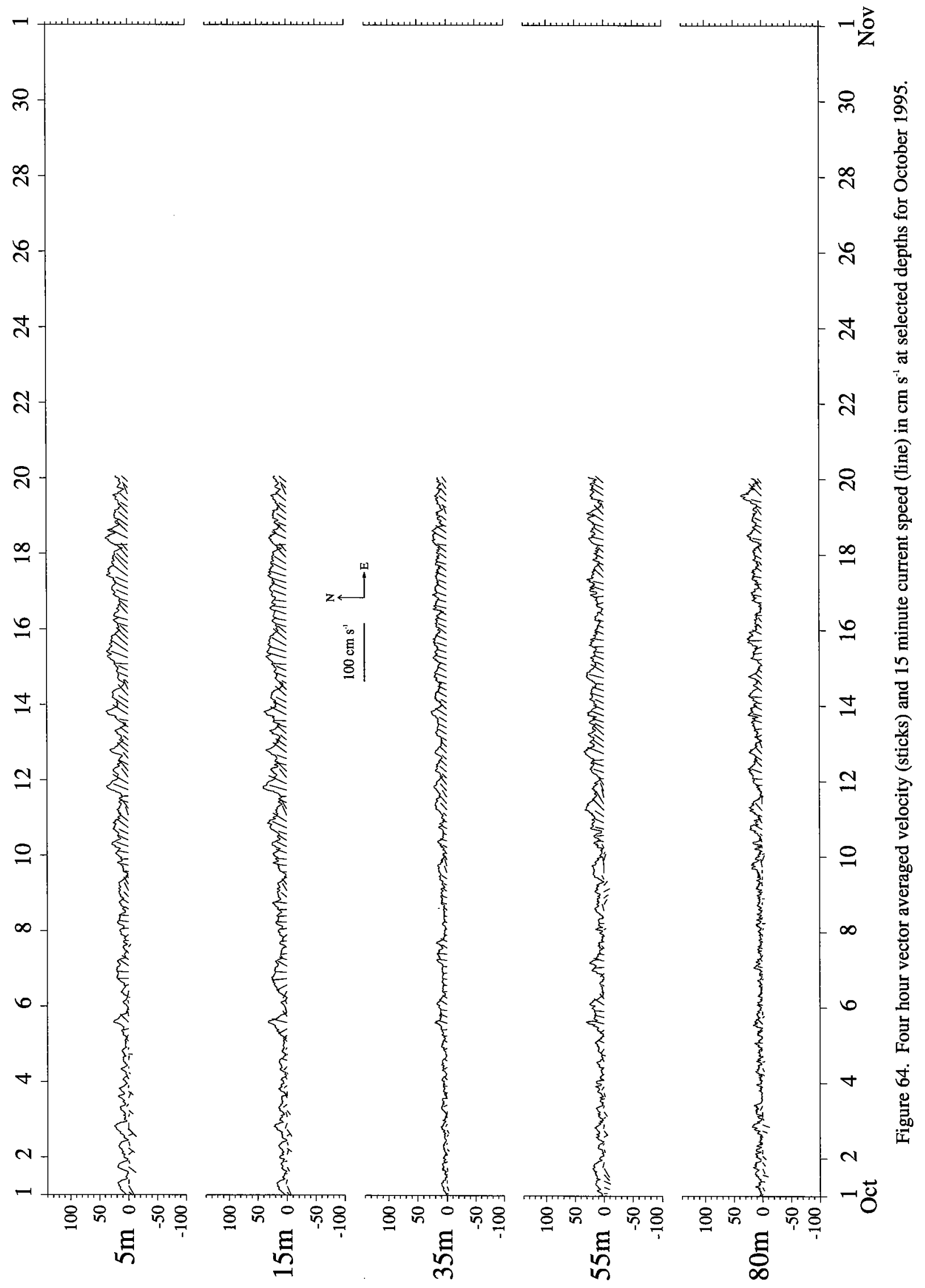




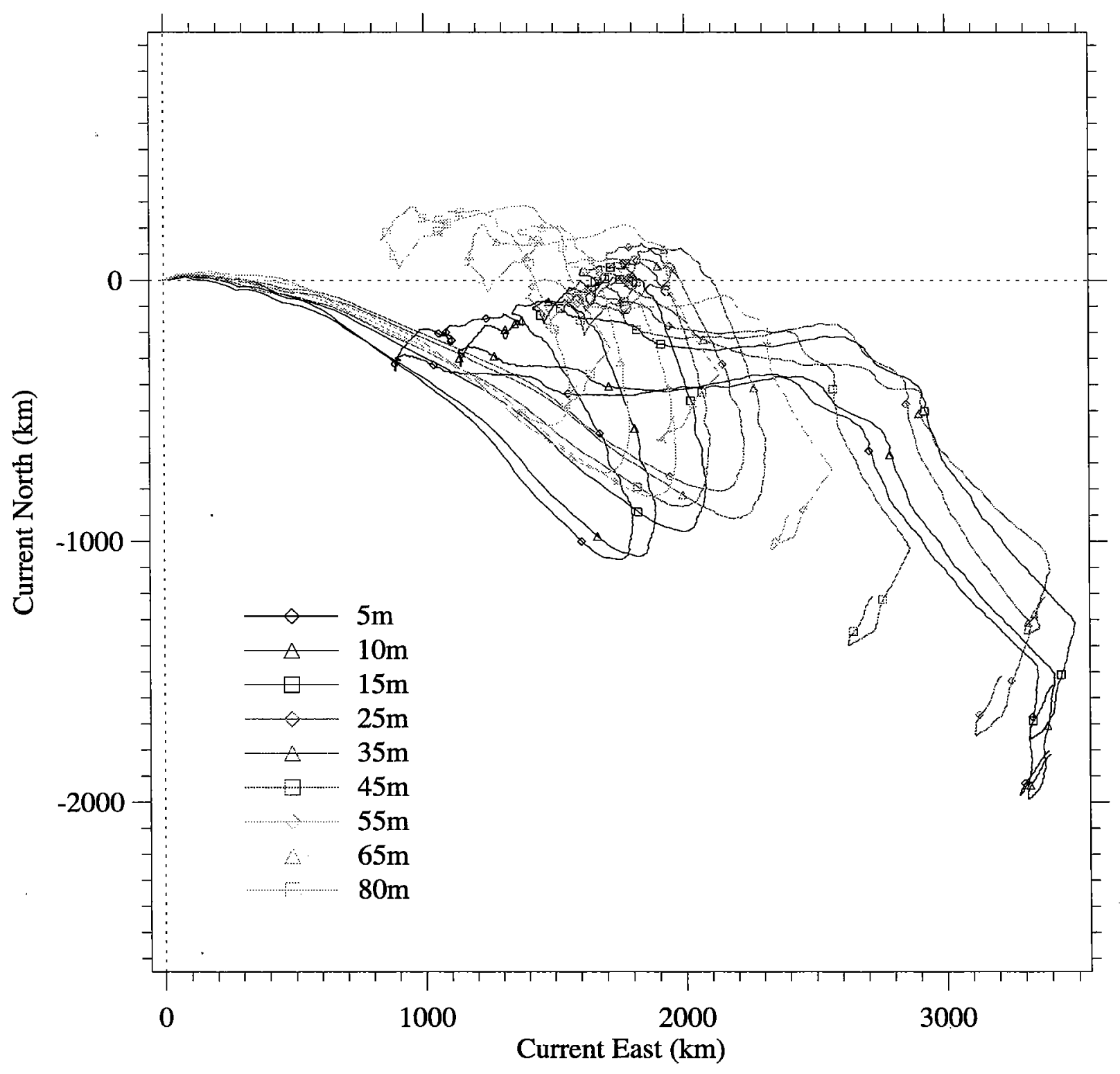

Figure 65. Progressive vectors from VMCM and MVMS current meters. Symbols are placed 30 days apart. 

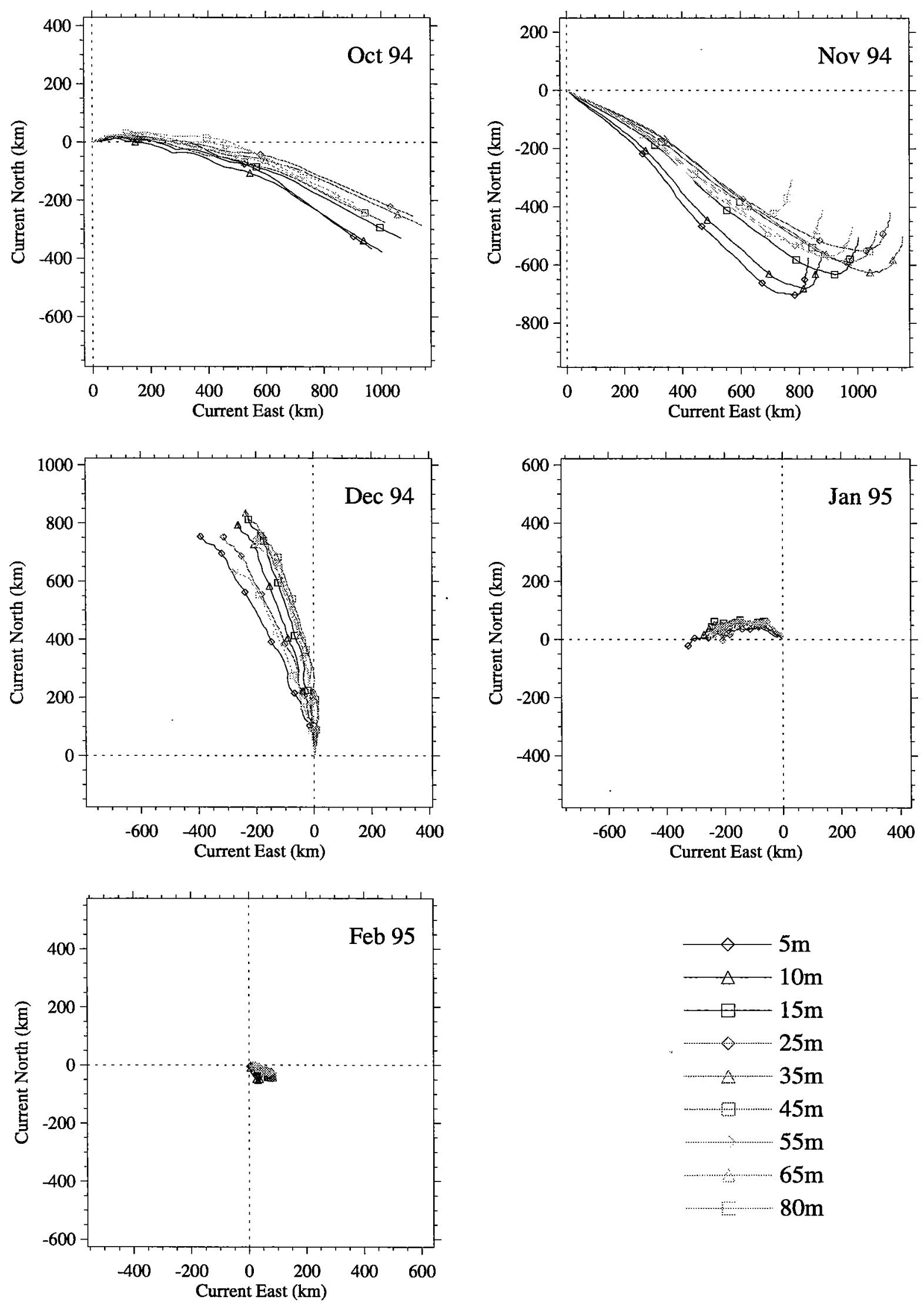

Figure 66. Progressive vectors from VMCM and MVMS current meters. Symbols are placed 5 days apart. 

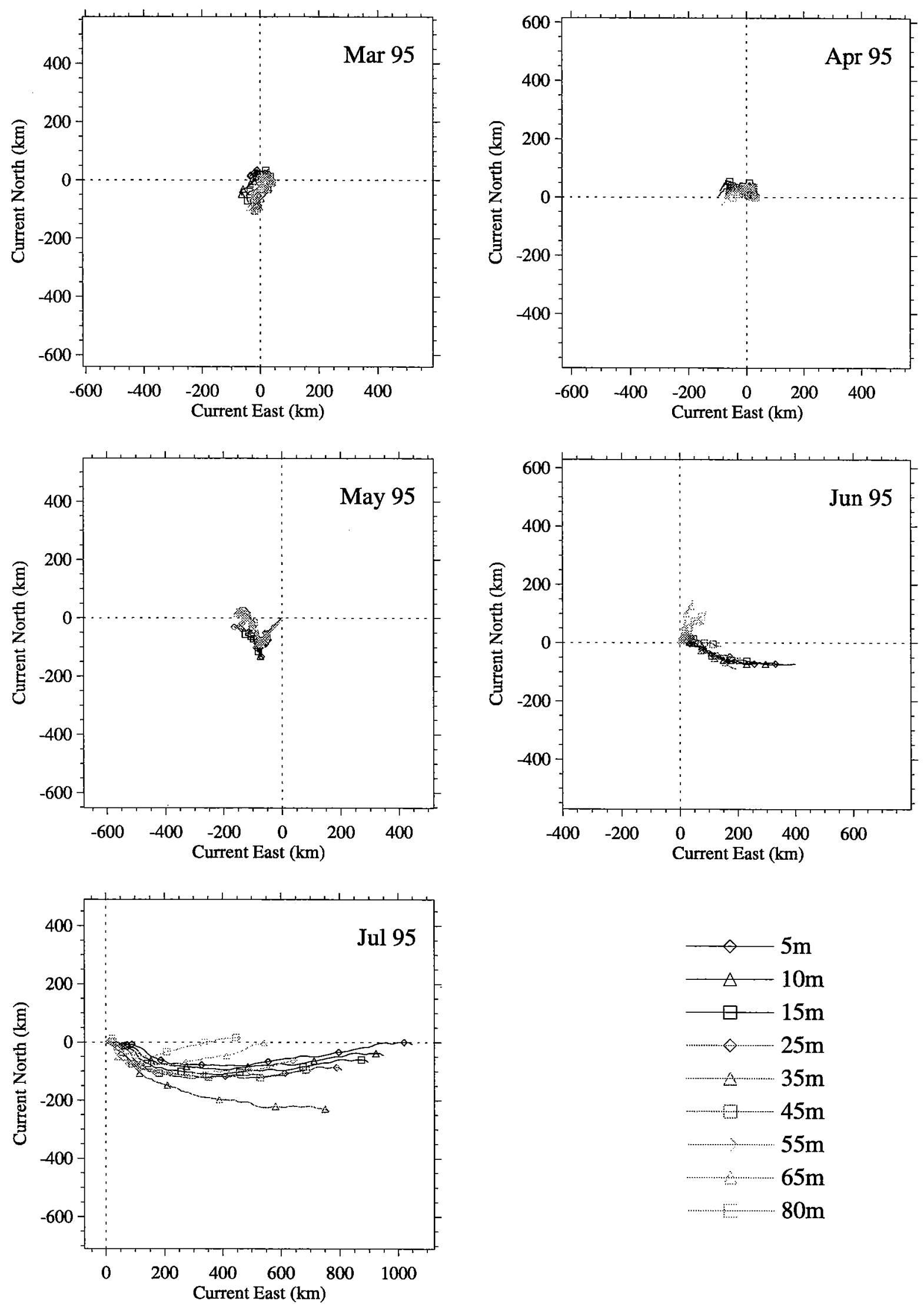

Figure 66. (continued) 

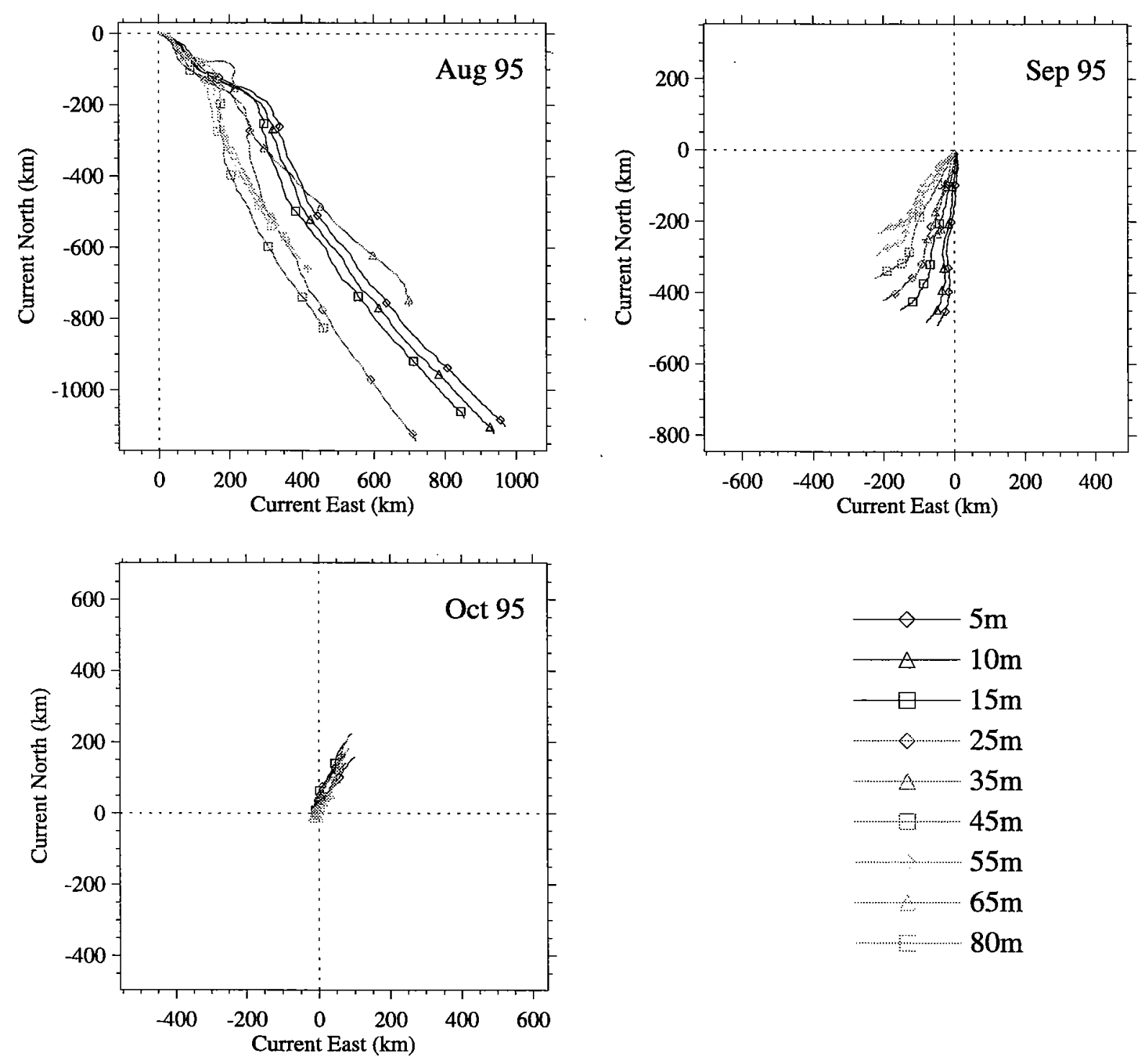

Figure 66. (continued) 

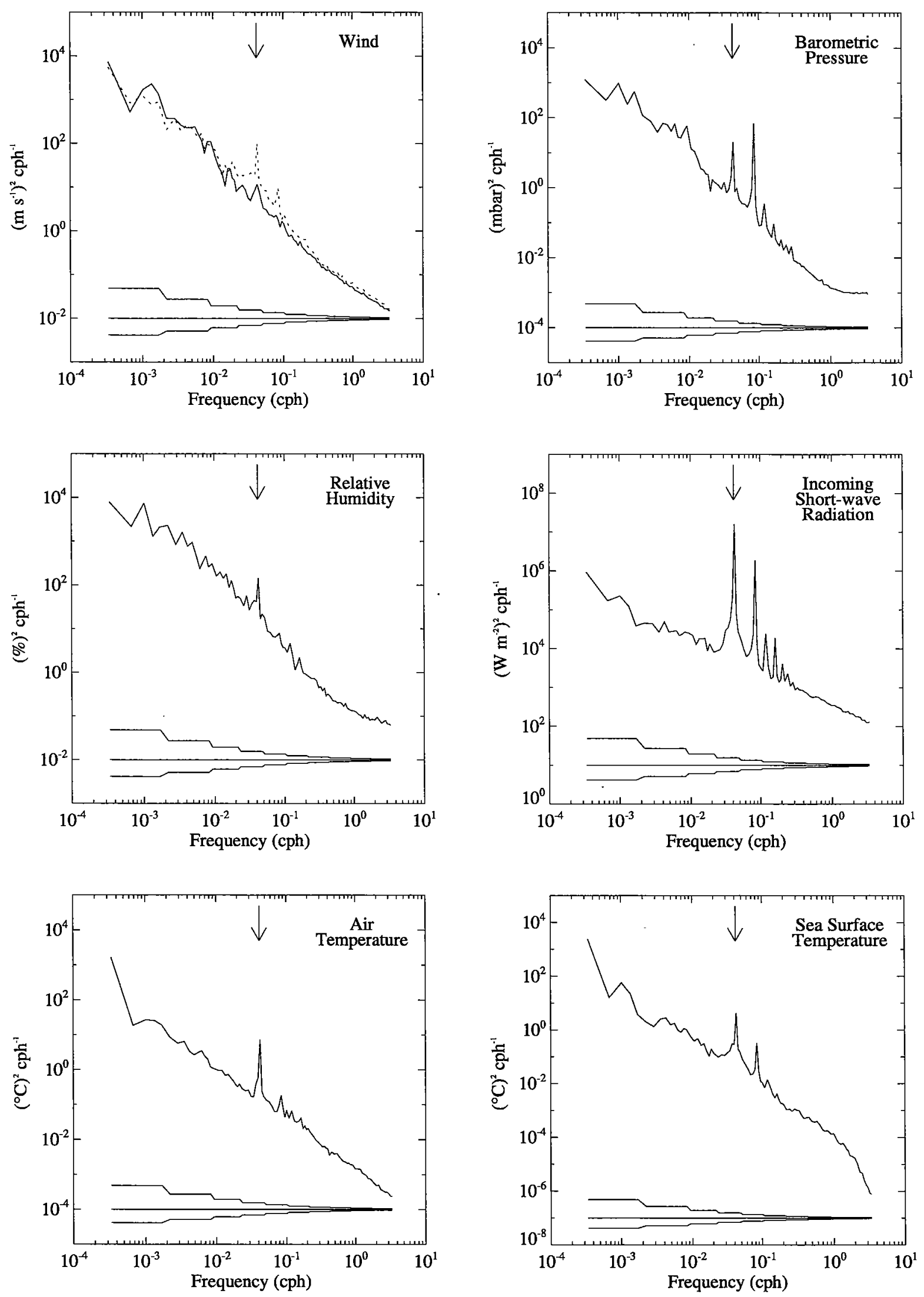

Figure 67. Autospectra of meteorological parameters. Rotary autospectra of the wind provides both clockwise (solid) and counter-clockwise (dotted) spectras. The arrow indicates the diurnal frequency $\left(24^{-1} \mathrm{cph}\right)$. 

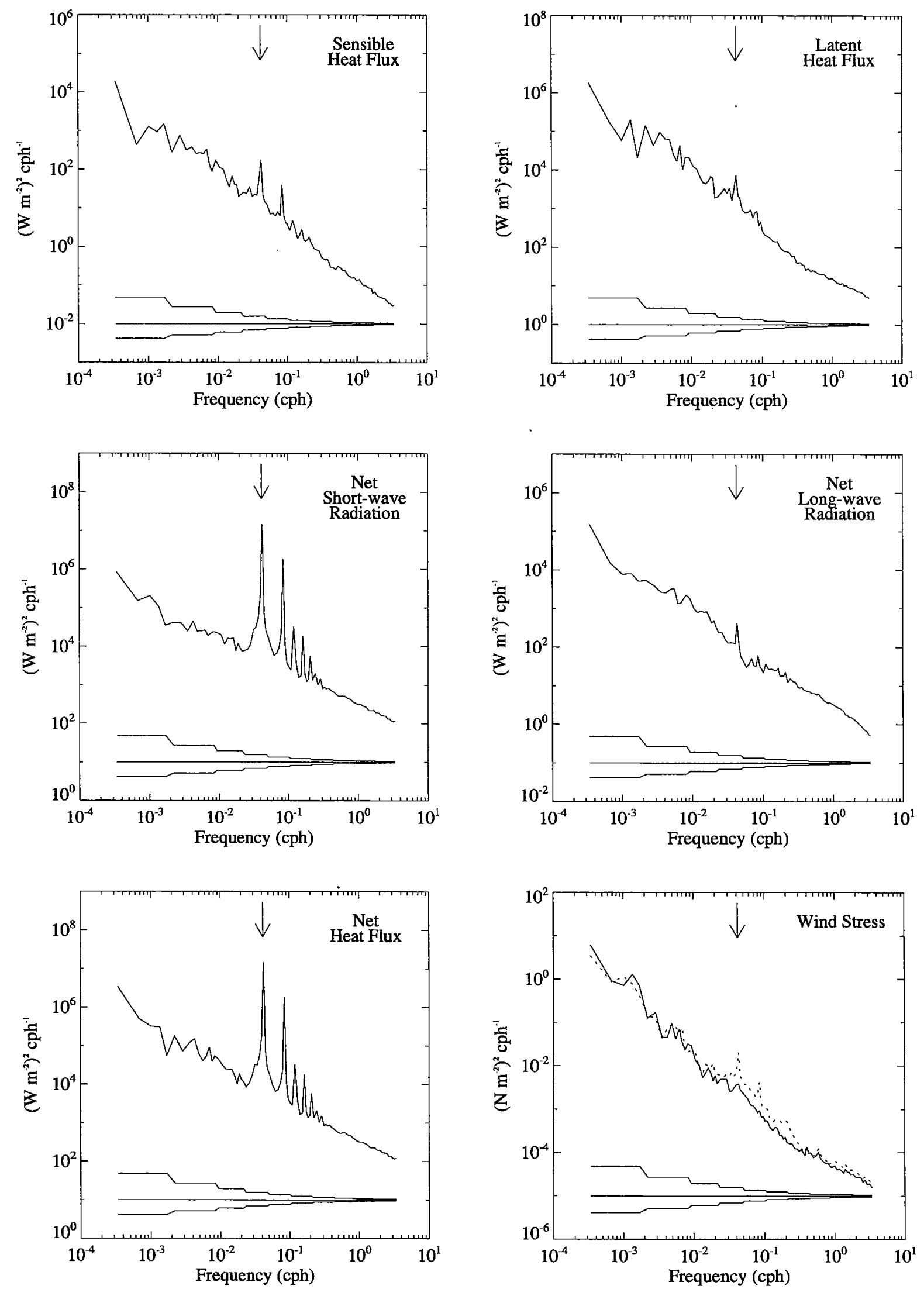

Figure 68. Autospectra of heat fluxes. Rotary autospectra of the wind stress provides both clockwise (solid) and counter-clockwise (dotted) spectras. The arrow indicates the diurnal frequency $\left(24^{-1} \mathrm{cph}\right)$. 

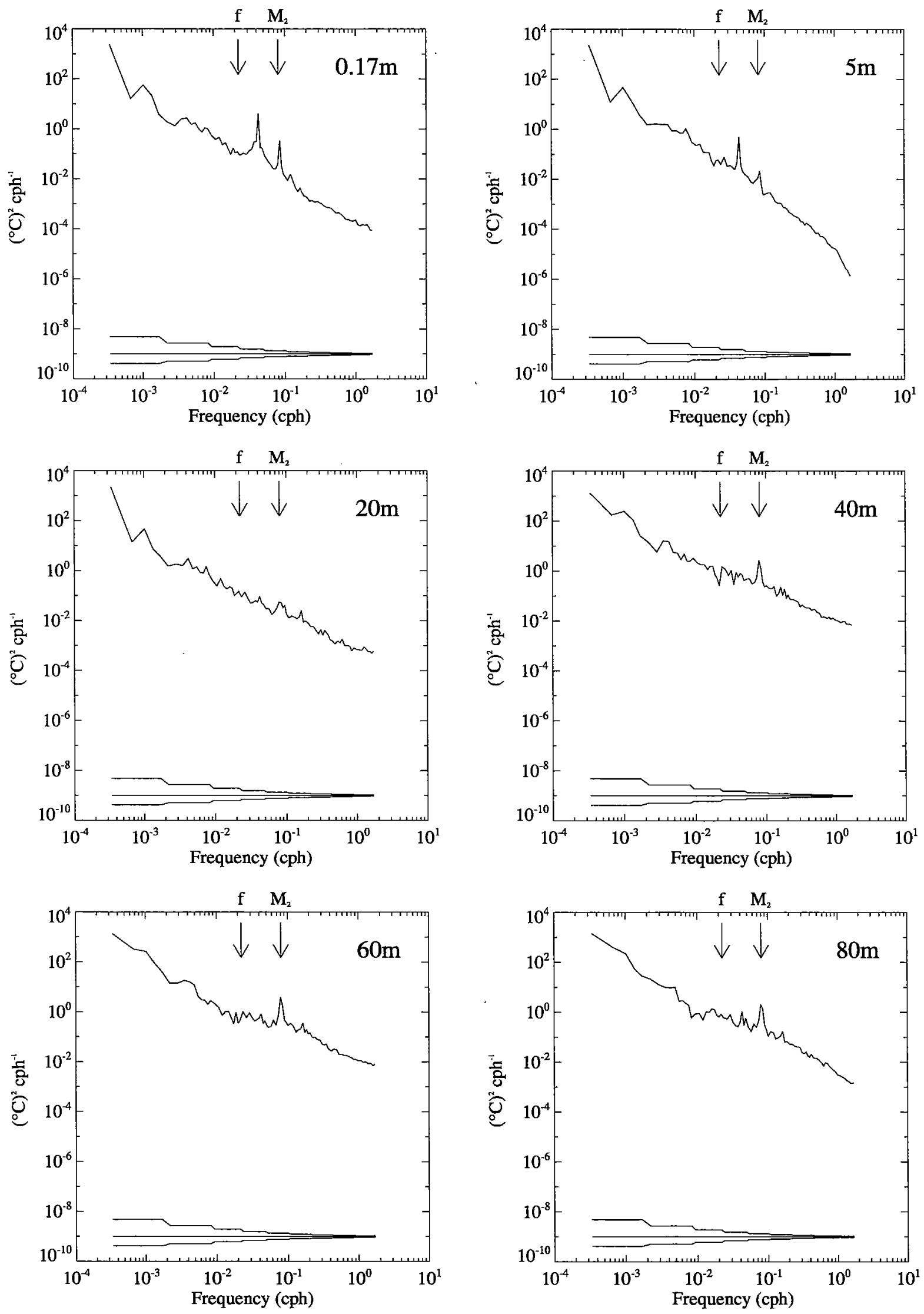

Figure 69. Autospectra of temperature at various depths. The tidal $\mathrm{M}_{2}$ and inertial frequencies are indicated with arrows. 

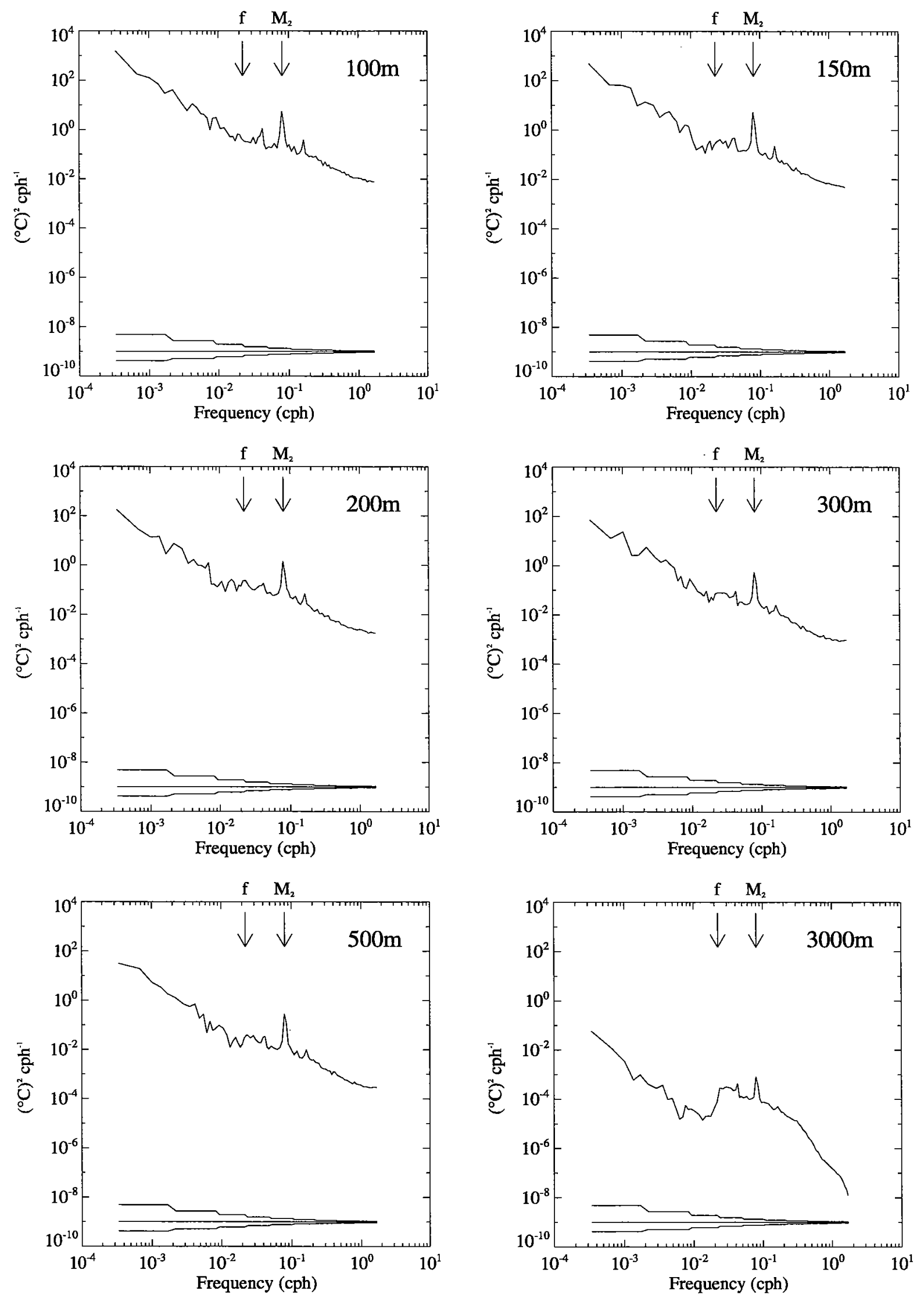

Figure 69. (continued) 

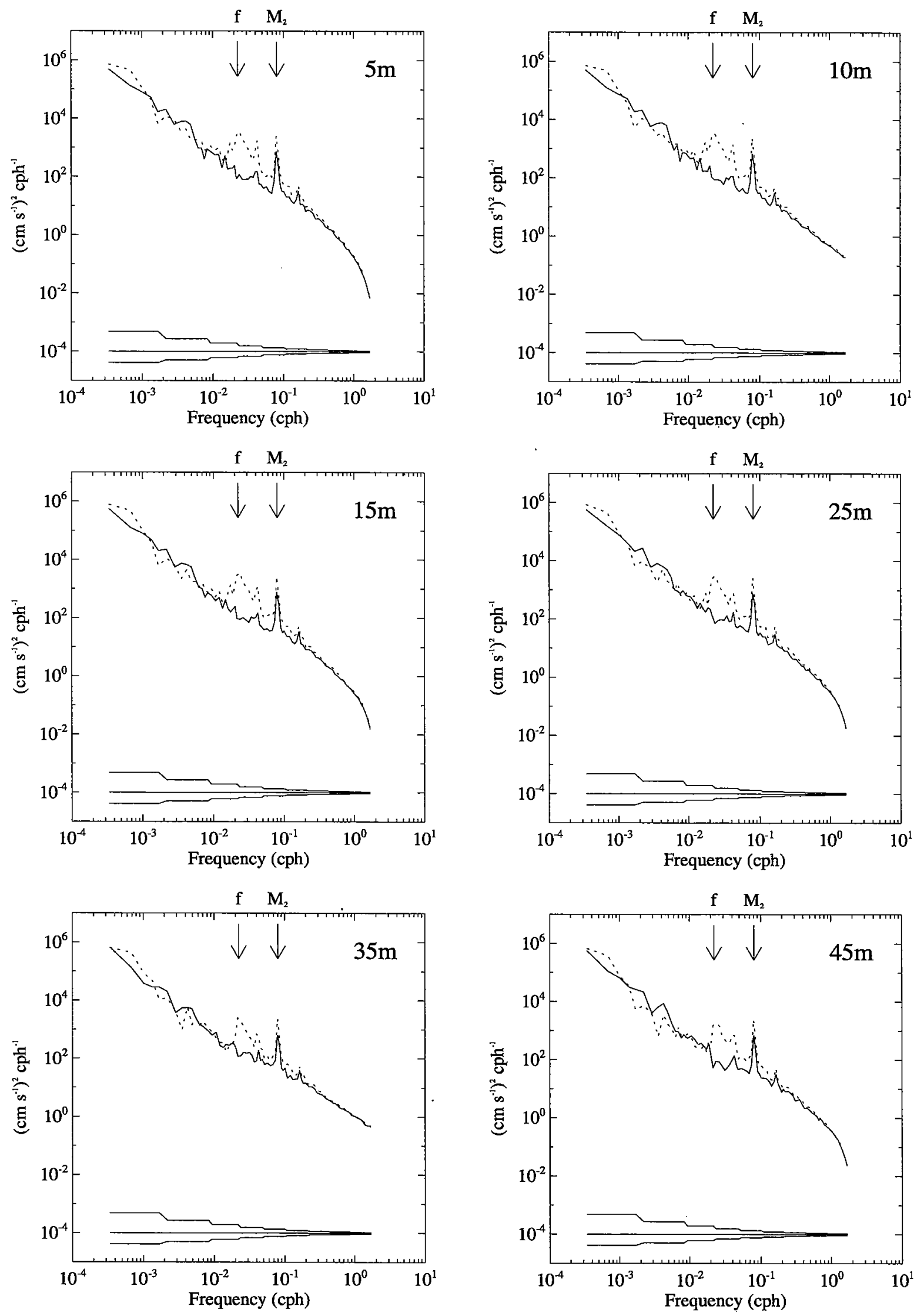

Figure 70. Rotary autospectra of velocity at various depths. The tidal $\mathrm{M}_{2}$ and inertial frequencies are indicated with arrows. Clockwise spectra are solid and counter-clockwise spectra are dotted. 

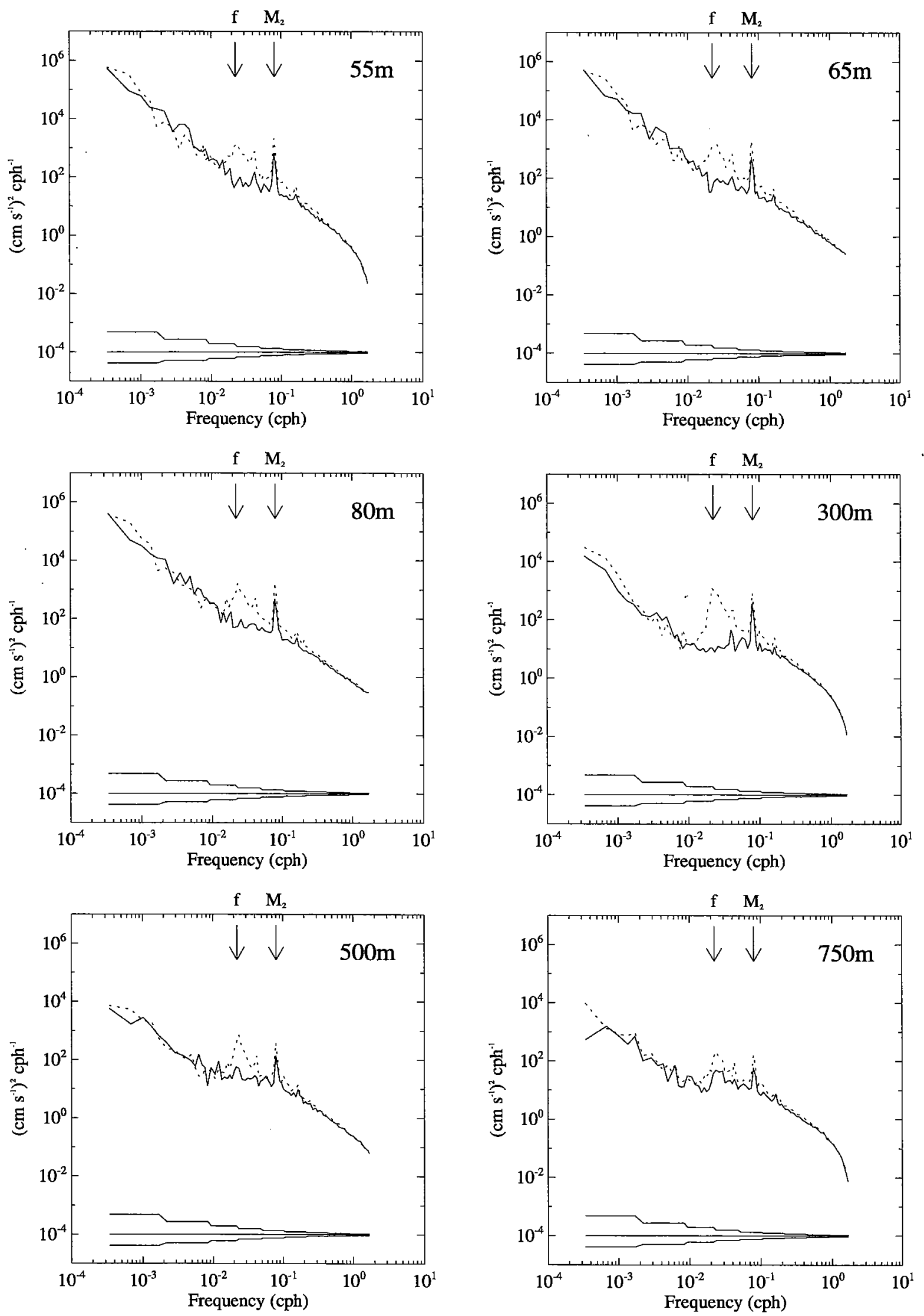

Figure 70. (continued) 


\section{Acknowledgments}

The success of the Arabian Sea experiment is due to the hard work and dedication of all the members of the Upper Ocean Processes Group, including Geoff Allsup, Steve Anderson, Albert Fischer, Nancy Galbraith, Dave Hosom, Will Ostrom, Dick Payne, Rick Trask, Jonathan Ware and Bryan Way. Dave Sigurdson (UCSB) and Cheng Ho (LDEO) performed the calibrations of the MVMS data. We would like to thank the captain and crew of the R/V Thomas Thompson for their skillful help during deployment and recovery. This work was supported by the Office of Naval Research Grant No. N00014-94-1-0161. 


\section{Literature Cited}

Anderson, S.P. and M.F. Baumgartner, 1997. Radiative heating errors in naturally ventilated air temperature measurements made from buoys. Journal of Atmospheric and Oceanic Technology. in press.

Clark, N.E., L. Eber, R.M. Laurs, J.A. Renner and J.F.T. Saur, 1974. Heat exchange between ocean and atmosphere in the eastern North Pacific for 1961-1971. NOAA Technical Report, NMFS SSRF-682. U.S. Department of Commerce, Washington, D.C.

Denbo, D. W. and W. H. Zhu, 1993. EPS Library User's Guide. Version 2.1. Pacific Marine Laboratory, National Oceanic and Atmospheric Administration. 131pp.

Fairall, C.W., E.F. Bradley, D.P. Rogers, J.B. Edson and G.S. Young, 1996a. Bulk parameterization of air-sea fluxes for TOGA COARE. Journal of Geophysical Research. 101, 3747-3764.

Fairall, C.W., E.F. Bradley, J.S. Godfrey, G.A. Wick, J.B. Edson, and G.S. Young, 1996b: The cool skin and the warm layer in bulk flux calculations. Journal of Geophysical Research. 101, 1295-1308.

Gill, G.C., 1983. Comparison testing of selected naturally ventilated solar radiation shields. Report submitted to NOAA Data Buoy Office, Bay St. Louis, Mississippi. In partial fulfillment of Contract \#NA-82-0A-A-266. NOAA/National Data Buoy Center, Bay St. Louis, Mississippi, 39529, U.S.A.

Ho, C., C.S. Kinkade, C. Langdon, M. Maccio and J. Marra, 1996. The forced upper ocean dynamics experiment in the Arabian Sea: Results from the multi-variable moored sensors from deployment-1 of the WHOI mooring. Lamont-Doherty Earth Observatory, Columbia University. LDEO Technical Report LDEO-96-5. 43pp.

Ho, C., C. Langdon, M. Maccio and J. Marra, 1997. Bioluminescence and optical variability in the sea ('Marine Light-Mixed Layers'): Moored observations in the North Atlantic Ocean. LDEO Technical Report LDEO-97-1. 12pp.

Hosom, D.S., R.A. Weller, R.E. Payne and K.E. Prada, 1995: The IMET (Improved Meteorology) ship and buoy system. Journal of Atmospheric and Oceanic Technology. $12,527-540$.

List, R.J., 1984. Smithsonian Meteorological Tables. Smithsonian Institution Press, Washington D.C. $572 \mathrm{pp}$.

Liu, W. T., K. B. Katsaros and J. A. Businger, 1979. Bulk parameterization of air-sea exchanges of heat and water vapor including the molecular constraints at the interface. Journal of the Atmospheric Sciences. 36, 1722-1735.

Ostrom, W.M., B.S. Way, R.A. Weller, J.D. Ware and R.P. Trask, 1996. Arabian Sea mixed layer dynamics experiment: Mooring recovery cruise report, $\mathrm{R} / \mathrm{V}$ Thomas Thompson cruise number 52, 14 October - 25 October 1995. Woods Hole Oceanographic Institution. Technical Report WHOI-96-11. 72pp. 
Payne, R. E., 1972. Albedo of the sea surface. Journal of the Atmospheric Sciences. 29,959970.

Prada, K.E., 1992. A system for shipboard analysis of buoy data. Woods Hole Oceanographic Institution. Technical Report WHOI-92-42. 29pp.

Rew, R., G. Davis and S. Emmerson, 1993. NetCDF users guide: An interface for data access. Version 2.3. Unidata Program Center. 186pp.

Sigurdson, D.E., T.D. Dickey and D. Manov, 1995. Arabian Sea Mooring Data Report: Deployment \#1 October 15, 1994 - April 20, 1995. University of California, Santa Barbara. Ocean Physics Laboratory Technical Report \#OPL-2-95. 26pp.

Sigurdson, D.E., T.D. Dickey and D. Manov, 1996. Arabian Sea Mooring Data Report: Deployment \#2 April 22, 1995 - October 20, 1995. University of California, Santa Barbara. Ocean Physics Laboratory Technical Report \#OPL-2-96. 26pp.

Trask, R.P., B.S. Way, W.M. Ostrom, G.P. Allsup and R.A. Weller, 1995a. Arabian Sea mixed layer dynamics experiment: Mooring deployment cruise report, R/V Thomas Thompson cruise number 40,11 October - 25 October 1994. Woods Hole Oceanographic Institution. Technical Report WHOI-95-01. 64pp.

Trask, R.P., R.A. Weller and W.M. Ostrom, 1995b. Arabian Sea mixed layer dynamics experiment: Mooring deployment cruise report, $\mathrm{R} / \mathrm{V}$ Thomas Thompson cruise number 46, 14 April - 29 April 1995. Woods Hole Oceanographic Institution. Technical Report WHOI-95-14. 92pp.

Way, B.S., 1996: A stand-alone relative humidity and air temperature logger. Woods Hole Oceanographic Institution Upper Ocean Processes Group January 1996 Technical Note. Upper Ocean Processes Group, c/o Rick Trask, Woods Hole Oceanographic Institution, Woods Hole, Massachusetts 02543. 2 pp. Also available at http://uop.whoi.edu.

Weller, R.A. and R.E. Davis, 1980. A vector measuring current meter. Deep Sea Research. 27A, 1122-1136.

Weller, R.A., D.L. Rudnick, R.E. Payne, J.P. Dean, N.J. Pennington and R.P. Trask, 1990. Measuring near-surface meteorology over the ocean from an array of surface moorings in the subtropical convergence zone. Journal of Atmospheric and Oceanic Technology. 7, 85-103. 


\section{Appendix A: Ancillary Data}

\section{$X B T$ and $C T D$}

Expendable bathythermographs (XBT) and conductivity/temperature/depth (CTD) profiles were collected during each deployment and recovery cruise (R/V/ Thomas Thompson cruise 40, 46 and 52). These data, including station times, positions, water depths and plots, are described in Trask et al. (1995a), Trask et al. (1995b) and Ostrom et al. (1996).

\section{Shipboard meteorological measurements}

Concurrent shipboard meteorological measurements were collected after each deployment and just before recovery at an approximate distance of 0.25 miles from the buoy. These measurements provide an independent check of the buoy measurements to determine if some sensors were damaged during deployment and to provide pre-recovery calibration information should a sensor be damaged on recovery. The R/V Thomas Thompson carries an IMET system and during cruises 46 and 52, a second meteorological system was mounted on the ship (Trask et al., 1995b; Ostrom et al., 1996). Both of these systems measure air temperature, relative humidity, barometric pressure and wind speed and direction. The shipboard IMET system also records incoming short-wave radiation. All of the meteorological sensors were mounted to the jackstaff at a height of approximately $16.33 \mathrm{~m}$. The ship also has a flow-through thermosalinograph capable of measuring temperature and conductivity. The intake for this flowthrough system is at $4 \mathrm{~m}$ depth. Data from the three deployment and recovery cruises (40,46 and $52)$ and four Seasoar cruises $(42,44,48$ and 51) were processed and are presented in Figures A1A7.

The bulk flux algorithm described in Section 3 (Fairall et al., 1996a) was used to estimate heat and momentum fluxes from the shipboard IMET and thermosalinograph measurements. Since no incoming long-wave radiation measurement was available, net long-wave was computed from estimated cloud cover, air and sea surface temperature and vapor pressure from Clark et al. (1974). Cloud cover was estimated from the observed incoming short-wave radiation and the theoretical clear-sky radiation (List, 1984) using an atmospheric transmission coefficient of 0.745 . Since cloud cover can only be estimated from incoming short-wave radiation during the day, a 30 hour centered average of cloud cover was used in the net long-wave calculation as an approximation of the mean cloud cover at any one time. The estimated heat and momentum fluxes from the three deployment and recovery cruises and the four Seasoar cruises are presented in Figures A8-A14. 
Drifting near-surface temperature array (DrifTAR)

A near-surface temperature array mounted to a modified three-ball radio float (DrifTAR) was used during R/V Thomas Thompson cruise 46 to investigate the effect of flow disturbance on the buoy-mounted near-surface temperature array (Trask et al., 1995b). The DrifTAR was deployed approximately 0.25 miles from the buoy at sunrise in three 12 hour long experiments. The position of the DrifTAR relative to the buoy was tracked using range and bearing measurements of both the DrifTAR and the buoy to the ship. The near-surface temperatures for the three experiments are shown with incoming short-wave radiation and wind speed in Figures A15A17.

\section{Numerical Weather Prediction Models}

Forecast fields generated by numerical weather prediction models from the European Centre for Medium Range Weather Forecasts (ECMWF) and the National Centers for Environmental Prediction (NCEP, formerly the National Meteorological Center [NMC]) were obtained for the duration of the Arabian Sea experiment. These fields include wind, air and sea surface temperature, a moisture variable (dew point temperature or specific humidity), barometric pressure, cloud cover, sensible and latent heat fluxes, net short- and long-wave radiation and wind stress. The NCEP model also includes predictions of precipitation rate. Both models are run four times daily at $0,6,12$ and $18 \mathrm{Z}$. To assess the accuracy of the model forecasts, each model variable was extracted at the grid point closest to the buoy (at 15.140N, 61.875E for ECMWF and $16.190 \mathrm{~N}, 61.875 \mathrm{E}$ for NCEP) and evaluated against the corresponding in situ measurement. The ECMWF and NCEP meteorological variables were compared to 30 minute buoy averages centered on $0,6,12$ and 18Z. Model heat and momentum fluxes were compared to 6 hour buoy averages. The moisture variable in each model was converted to relative and specific humidity for the comparisons.

Statistics of the difference between the models and the buoy observations are presented in Tables A1 and A2. These tables include the mean, standard deviation and standard error of the differences, the correlation coefficient and two sets of regression coefficients. Positive differences indicate that the model data is higher or larger than the buoy averages. The first set of regression coefficients are from a simple, linear regression yielding a slope and offset. The other regression coefficient reported in Tables A1 and A2 is the slope of a regression line forced through zero. Plots showing the ECMWF model and the buoy time series, a scatterplot and a histogram of the differences are presented in Figures A18-A30 and the same comparison plots for the NCEP model are provided in Figures A31-A43. The two sets of regression coefficients are superscripted as the simple linear regression (1) and the regression forced through zero (2) in Figures A18-A43. 
Table A1. Mean, standard deviation and standard error of the difference between the ECMWF model and in situ buoy observations. Positive differences indicate that the model values are higher than those of the buoy. The correlation coefficient $(r)$ and two sets of regression coefficients are also reported.

\begin{tabular}{|c|c|c|c|c|c|c|c|c|}
\hline \multirow[b]{2}{*}{ Variable } & \multirow[b]{2}{*}{ Unit } & \multirow[b]{2}{*}{ Mean } & \multirow[b]{2}{*}{ Std. Dev. } & \multirow[b]{2}{*}{ Std. Err. } & \multirow[b]{2}{*}{$\mathbf{r}$} & \multicolumn{2}{|c|}{ Regression $^{\mathrm{a}}$} & \multirow[b]{2}{*}{ Slope $^{\mathrm{b}}$} \\
\hline & & & & & & $\mathrm{c}_{1}$ & $\mathrm{c}_{0}$ & \\
\hline Wind speed at $10 \mathrm{~m}^{\mathrm{c}}$ & $\mathrm{m} \mathrm{s}^{-1}$ & 0.249 & 1.860 & 0.049 & 0.869 & 0.89404 & 1.004 & 1.0065 \\
\hline Wind direction & $\circ$ & 2.2 & 32.9 & 0.9 & 0.957 & 1.0234 & 2.8 & 1.0182 \\
\hline Barometric pressure & mbar & 0.42 & 0.64 & 0.02 & 0.992 & 0.92713 & 74.05 & 1.0004 \\
\hline Air temperature at $2 \mathrm{~m}^{\mathrm{d}}$ & ${ }^{\circ} \mathrm{C}$ & 0.070 & 0.796 & 0.021 & 0.895 & 0.98415 & 0.493 & 1.0026 \\
\hline Relative humidity at $2 \mathrm{~m}^{\mathrm{d}}$ & $\%$ & -0.53 & 9.21 & 0.24 & 0.405 & 0.39051 & 46.99 & 0.98595 \\
\hline Specific humidity at $2 \mathrm{~m}^{\mathrm{d}}$ & $\mathrm{g} \mathrm{kg}^{-1}$ & -0.106 & 1.672 & 0.044 & 0.821 & 0.73420 & 4.401 & 0.98637 \\
\hline Sea surface temperature & ${ }^{\circ} \mathrm{C}$ & -0.051 & 0.499 & 0.013 & 0.948 & 0.88784 & 3.005 & 0.99777 \\
\hline Sensible heat flux & $\mathrm{W} \mathrm{m}^{-2}$ & -2.89 & 6.65 & 0.17 & 0.728 & 1.0961 & -2.72 & 1.1994 \\
\hline Latent heat flux & $\mathrm{W} \mathrm{m} \mathrm{m}^{-2}$ & -21.84 & 48.00 & 1.25 & 0.660 & 0.72857 & -55.13 & 1.1028 \\
\hline Net short-wave radiation & $\mathrm{W} \mathrm{m}^{-2}$ & -25.08 & 82.58 & 2.16 & 0.959 & 0.88289 & 3.42 & 0.88874 \\
\hline Net long-wave radiation & $\mathrm{W} \mathrm{m}^{-2}$ & -2.06 & 19.53 & 0.51 & 0.697 & 0.68749 & -20.39 & 0.98070 \\
\hline Net heat flux & $\mathrm{W} \mathrm{m} \mathrm{m}^{-2}$ & -51.87 & 90.40 & 2.36 & 0.952 & 0.88739 & -45.06 & 0.85747 \\
\hline Wind stress & $\mathrm{N} \mathrm{m}^{-2}$ & 0.00485 & 0.04734 & 0.00124 & 0.898 & 0.86395 & 0.01856 & 0.95106 \\
\hline
\end{tabular}

${ }^{a}$ Model $=c_{1} \cdot$ Buoy $+c_{0}$

b Model $=$ Slope $\cdot$ Buoy

c The $10 \mathrm{~m}$ buoy wind speed was estimated from the boundary layer profile computed in the bulk flux algorithm.

d The $2 \mathrm{~m}$ buoy air temperature, relative humidity and specific humidity were estimated from the boundary layer profile computed in the bulk flux algorithm.

Table A2. Mean, standard deviation and standard error of the difference between the NCEP model and in situ buoy observations. Positive differences indicate that the model values are higher than those of the buoy. The correlation coefficient (r) and two sets of regression coefficients are also reported.

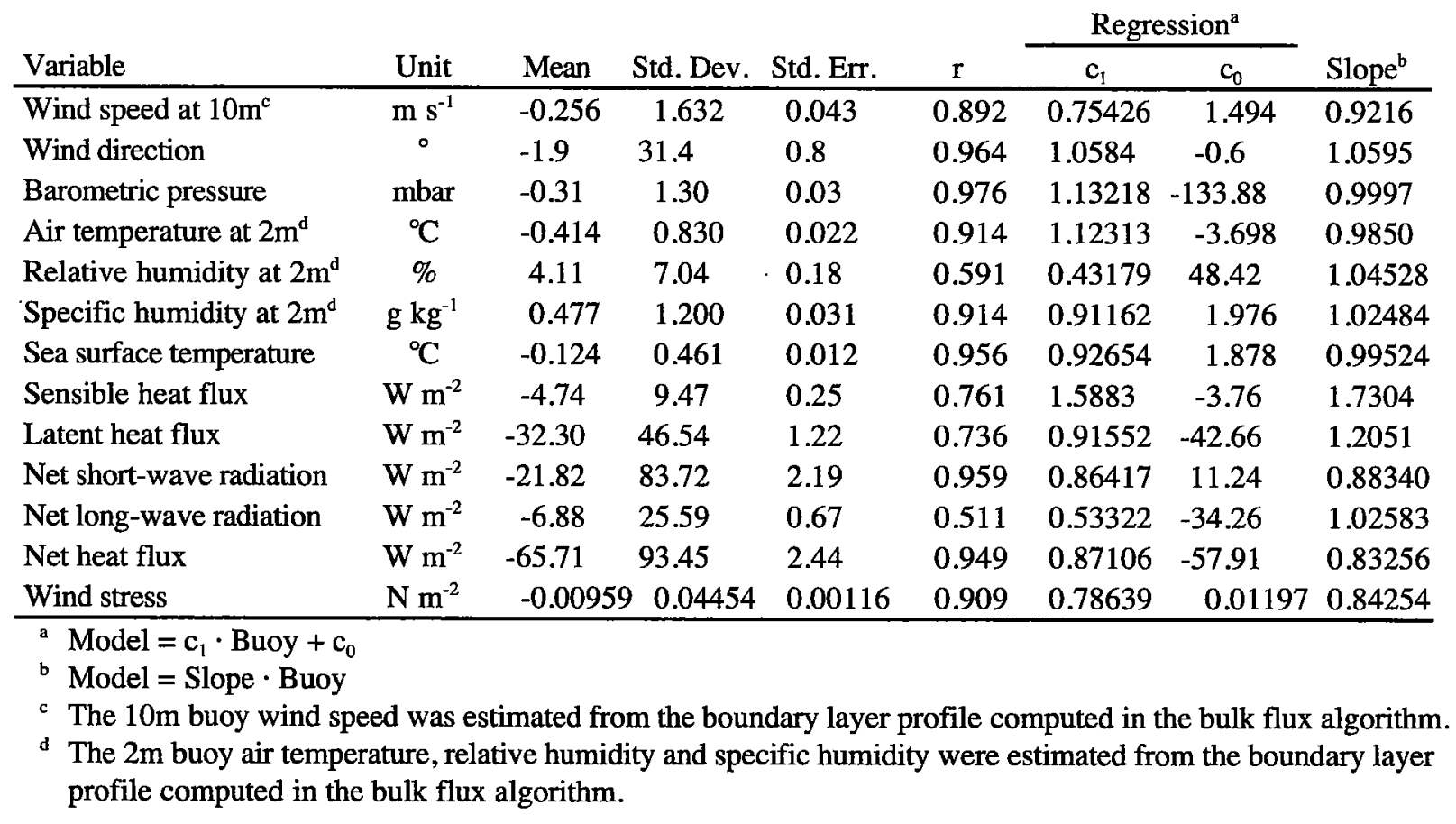




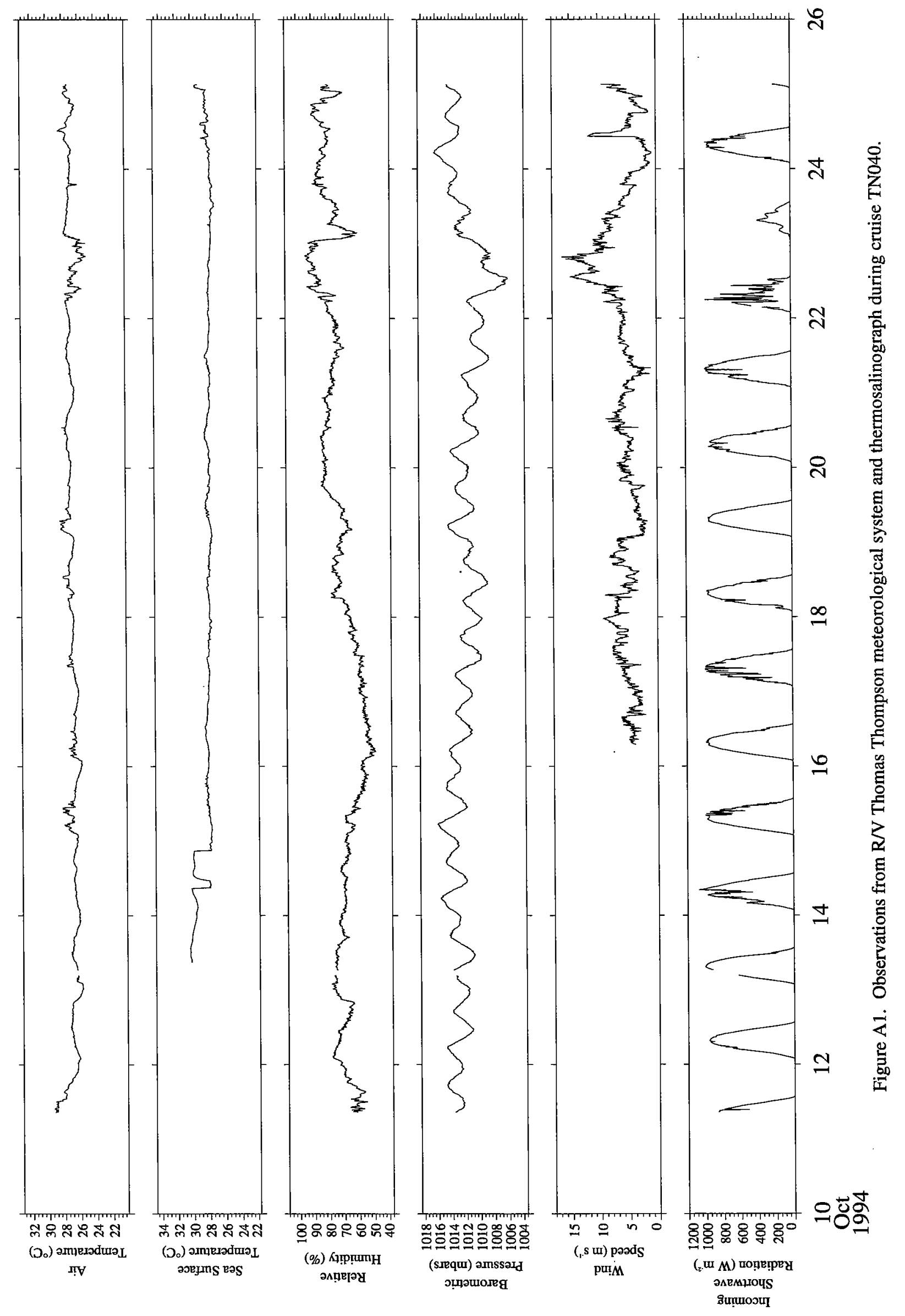




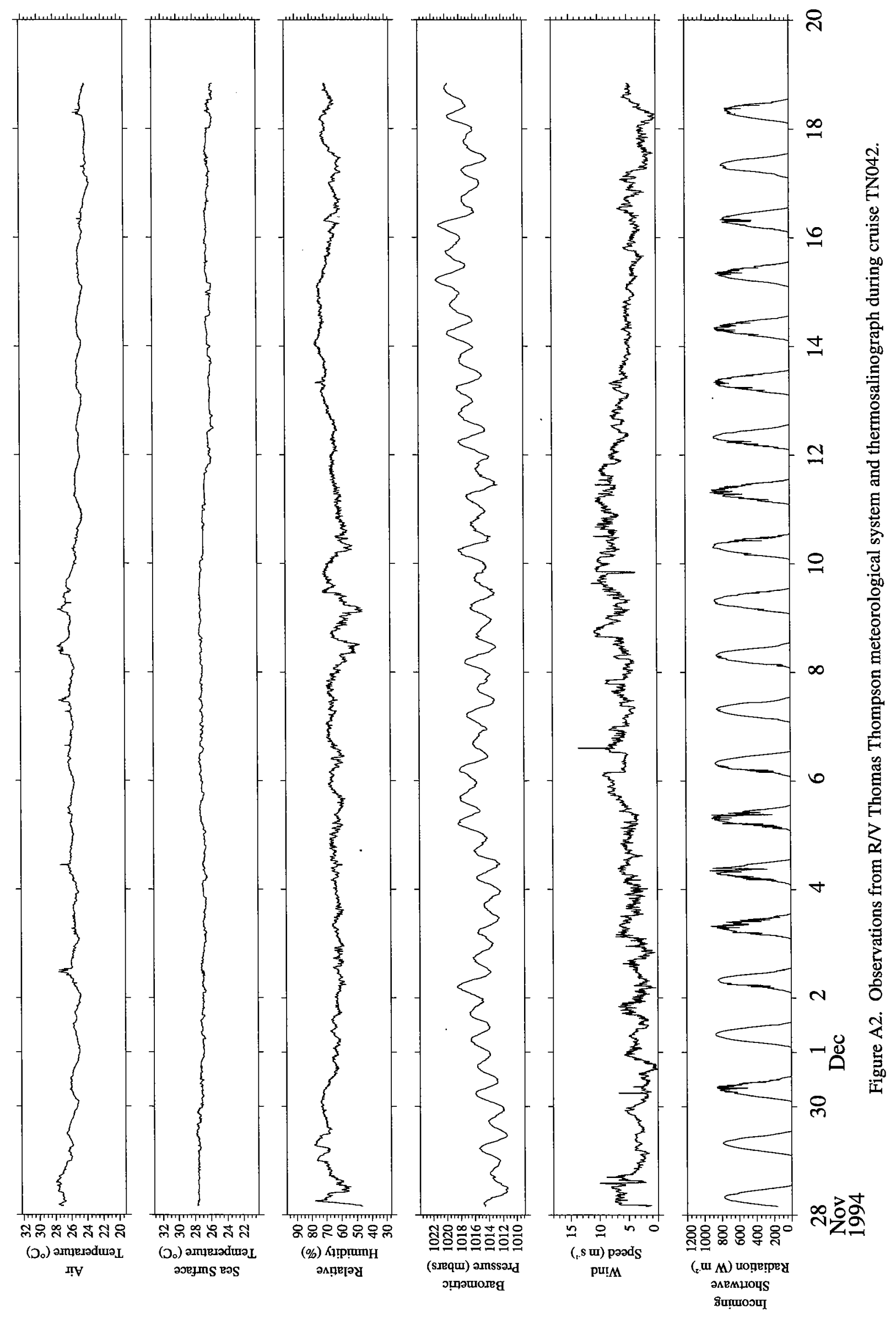




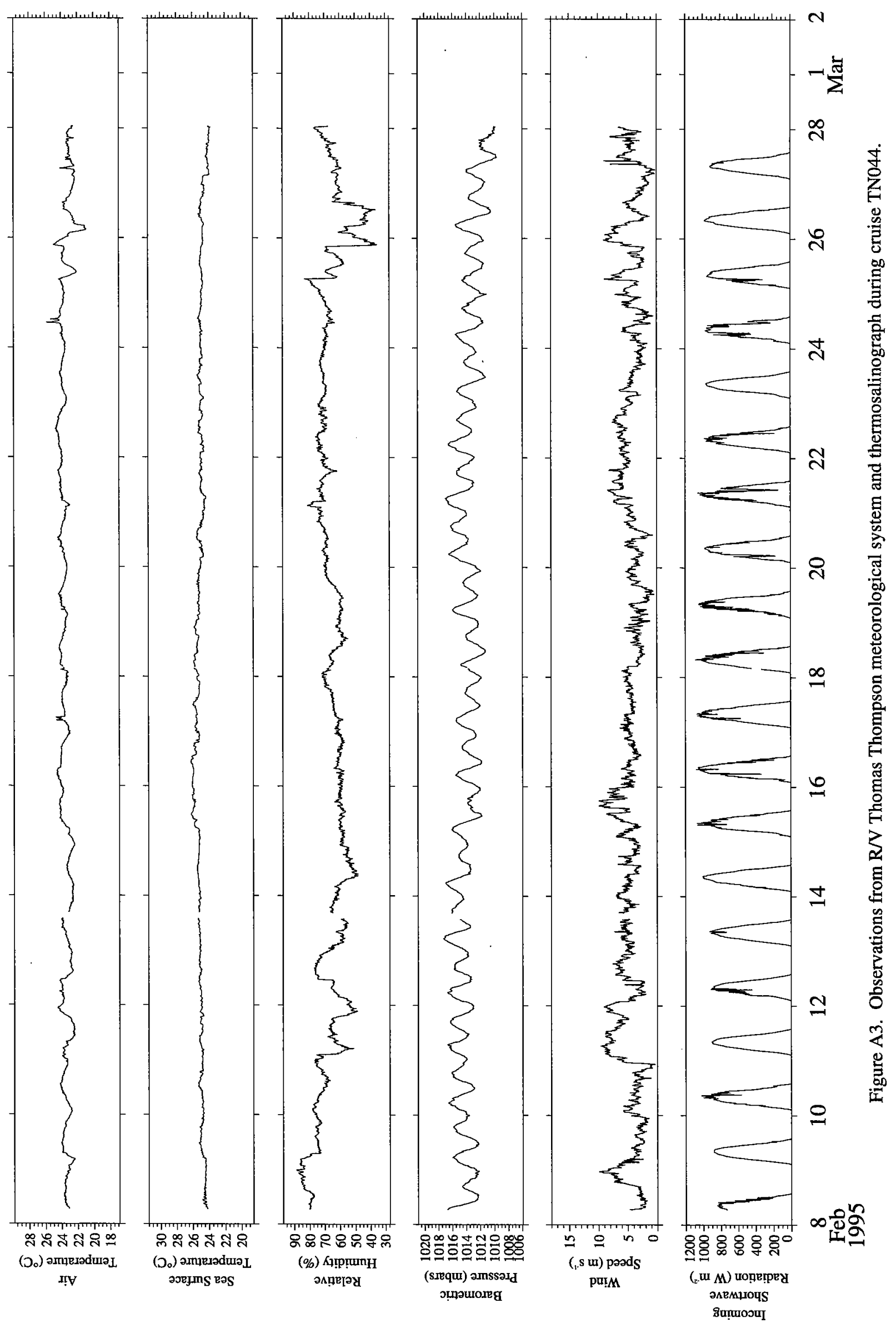




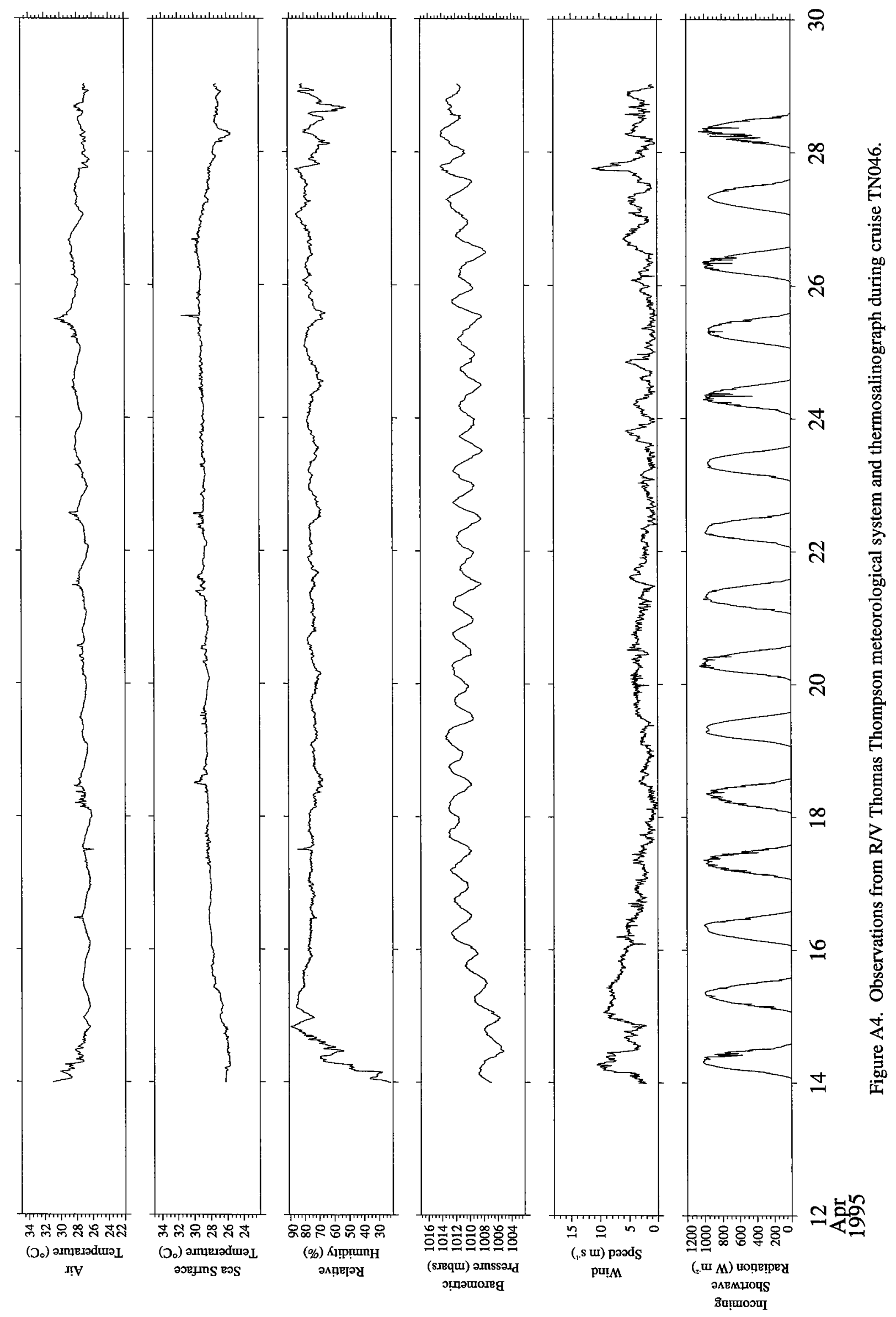




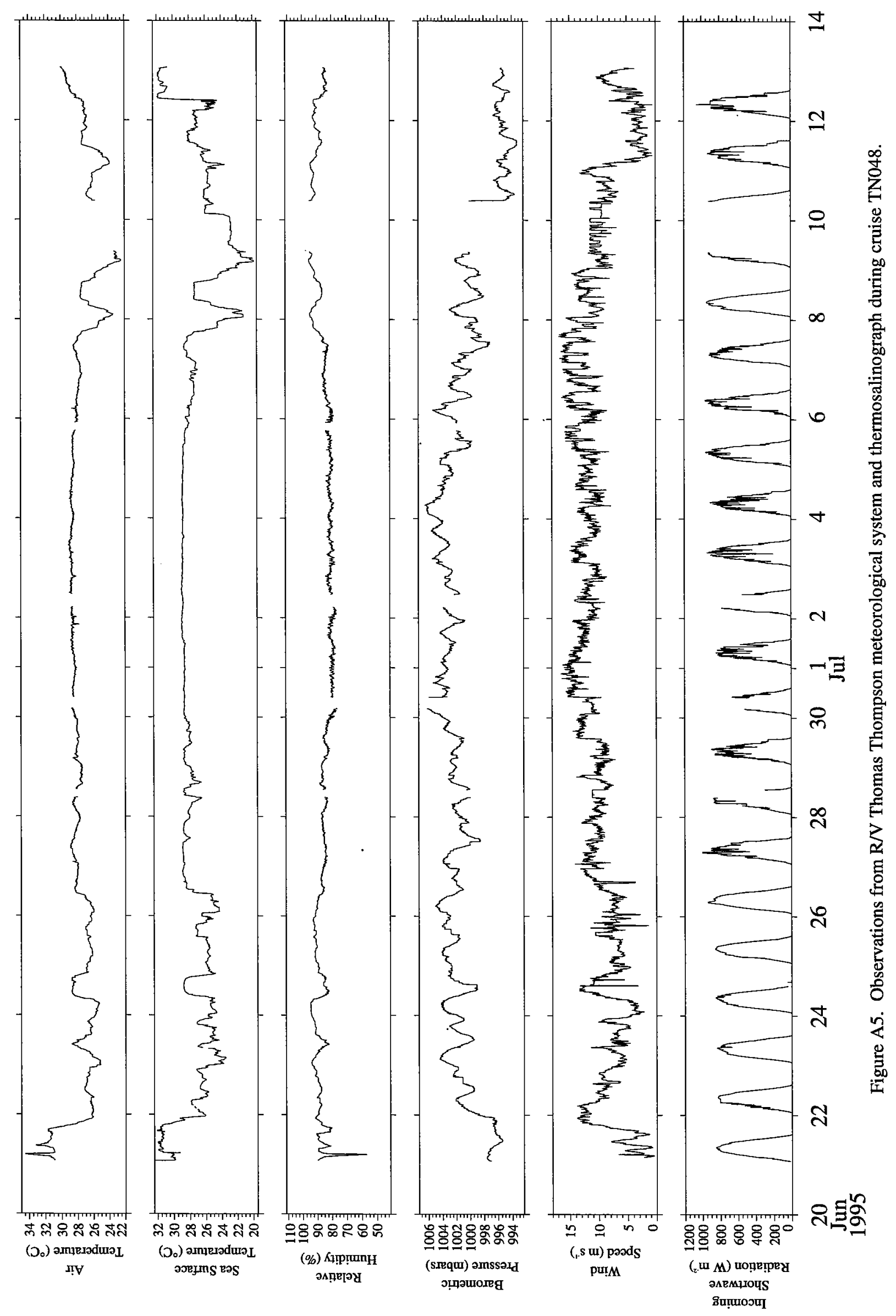




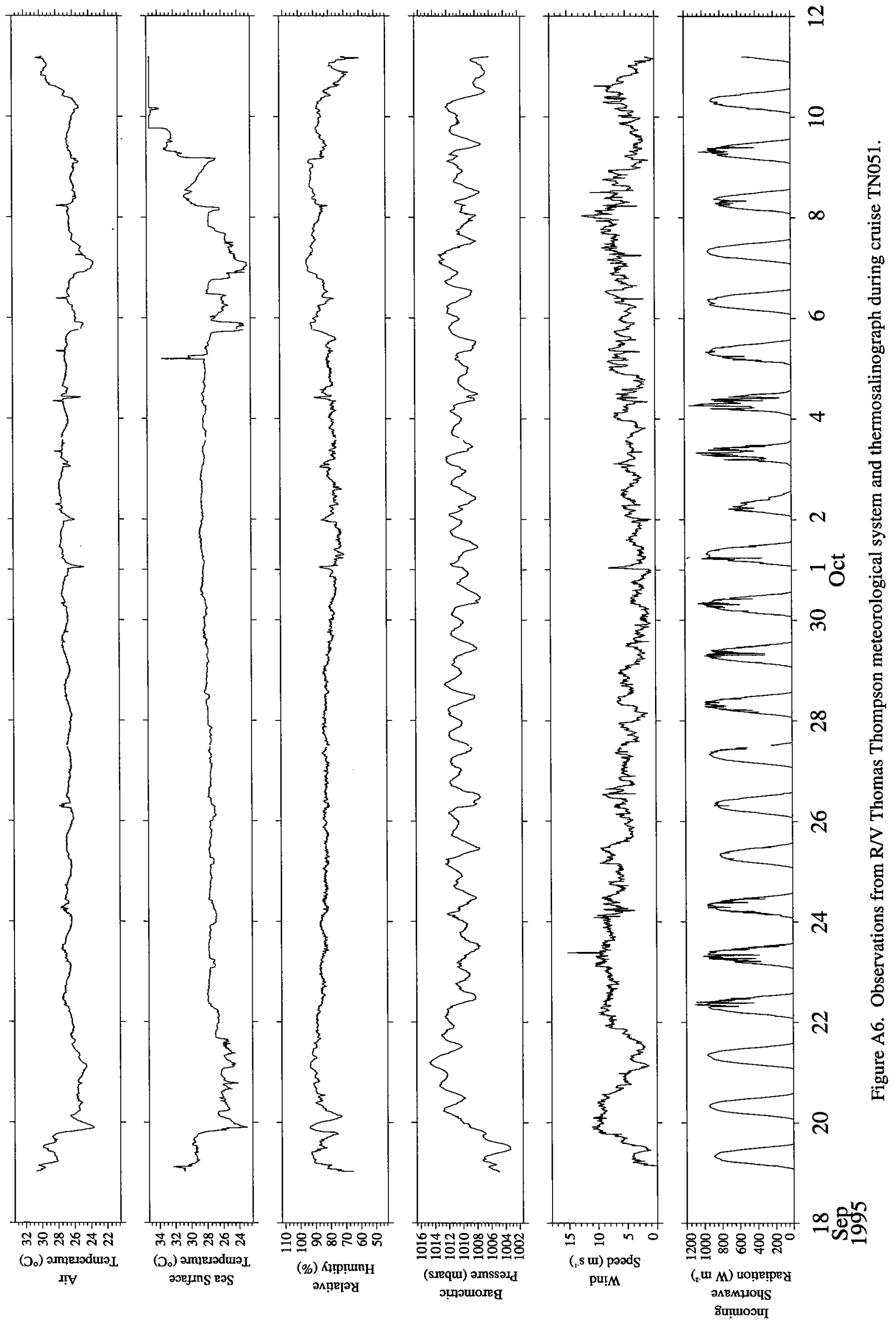




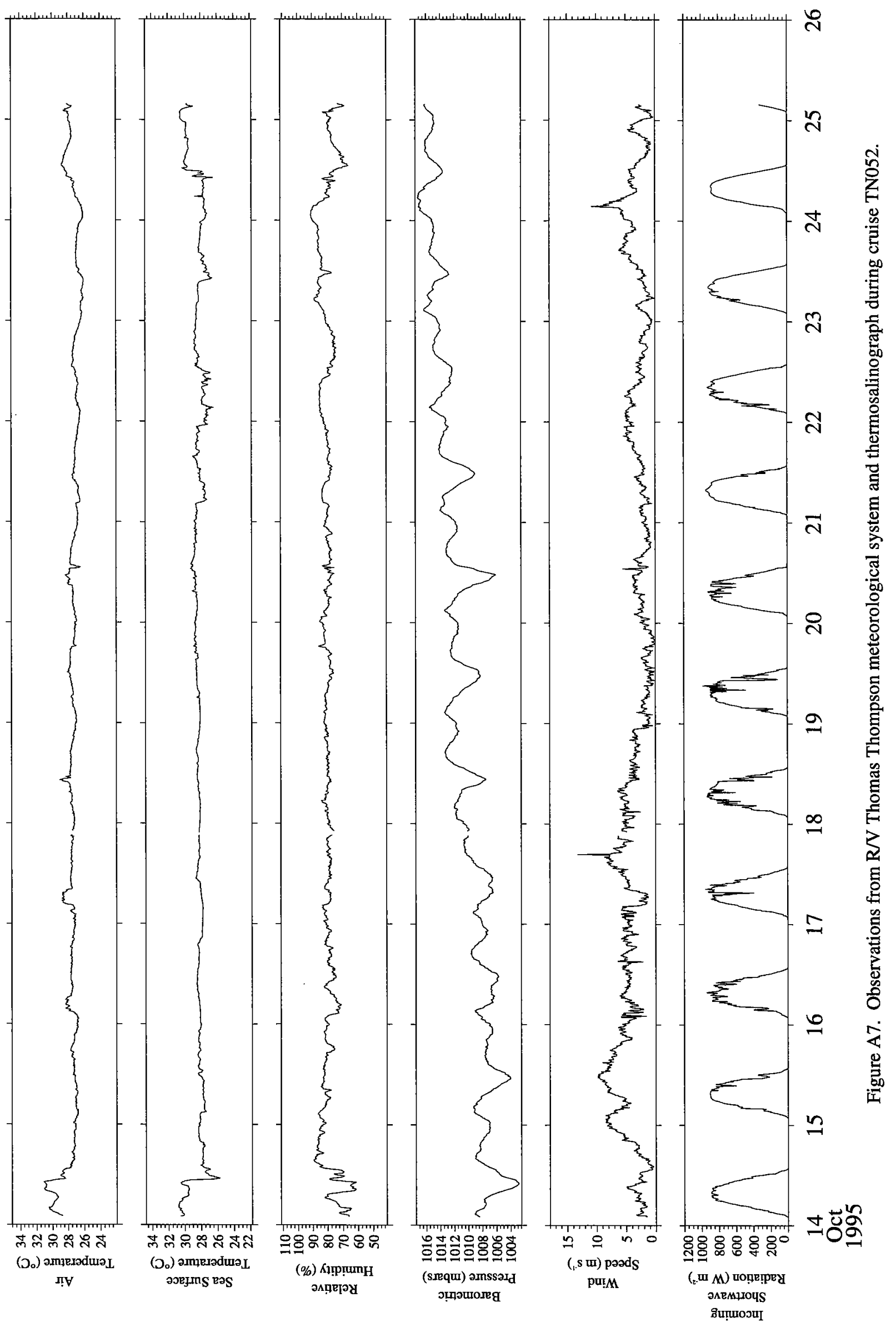




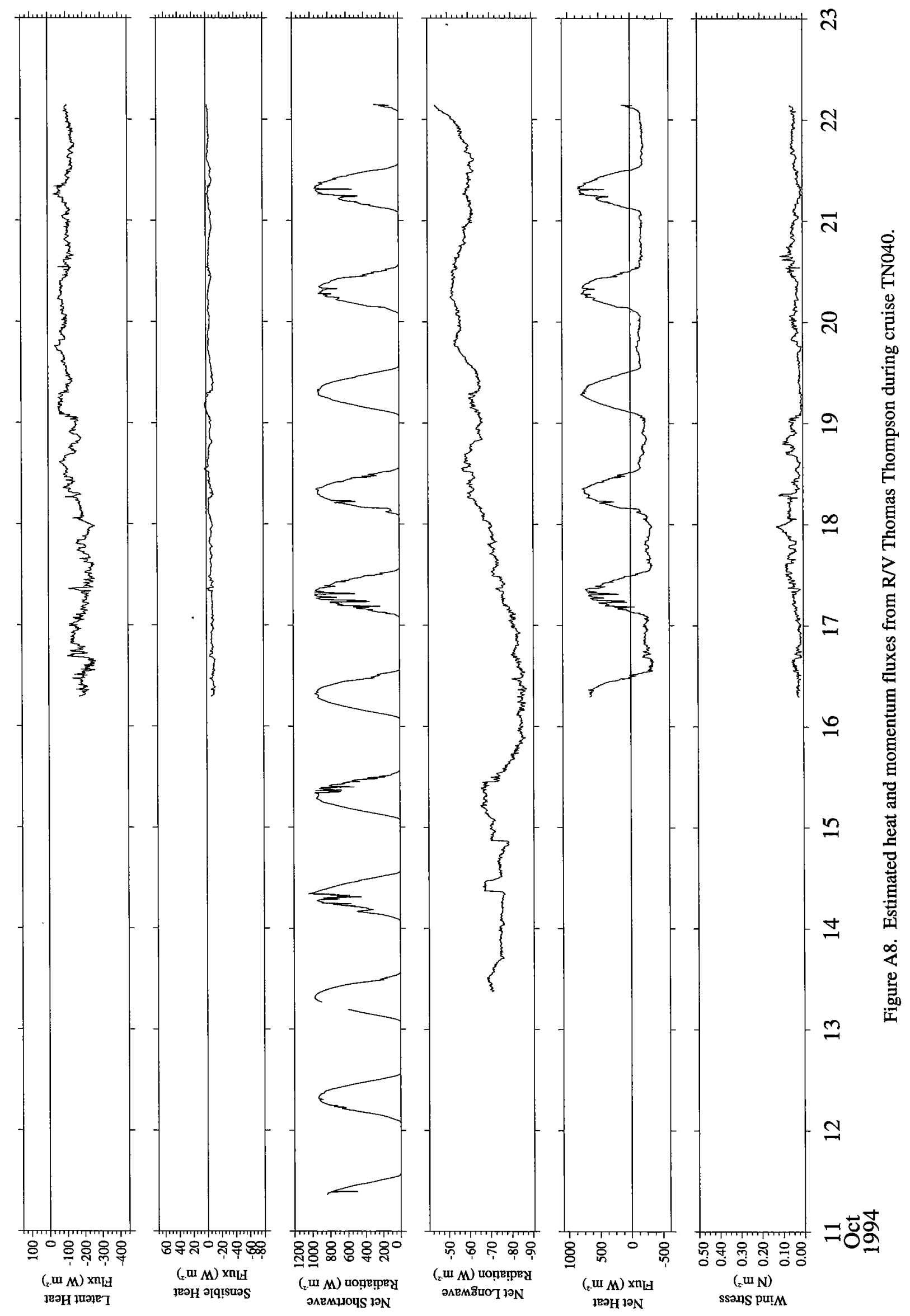




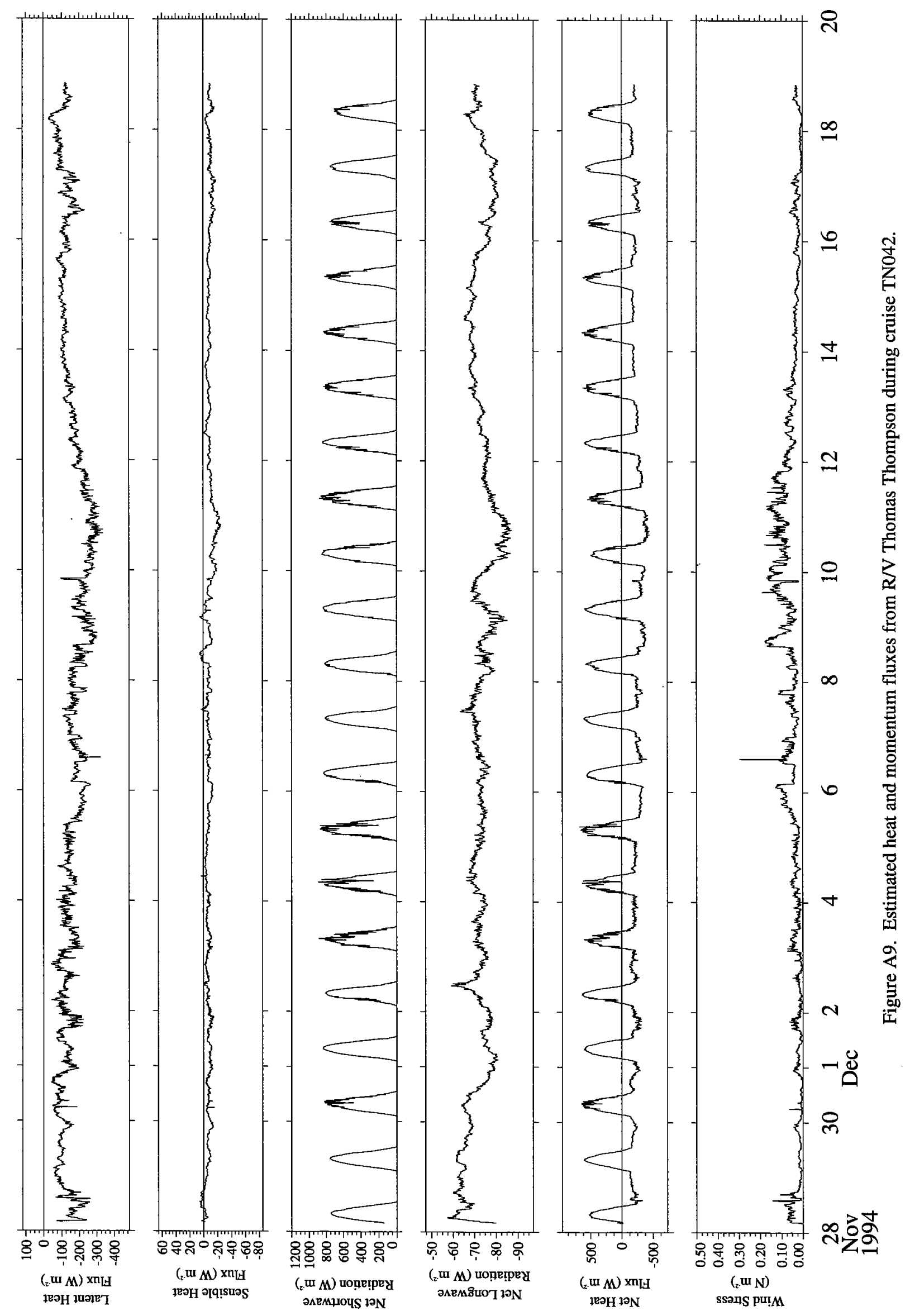




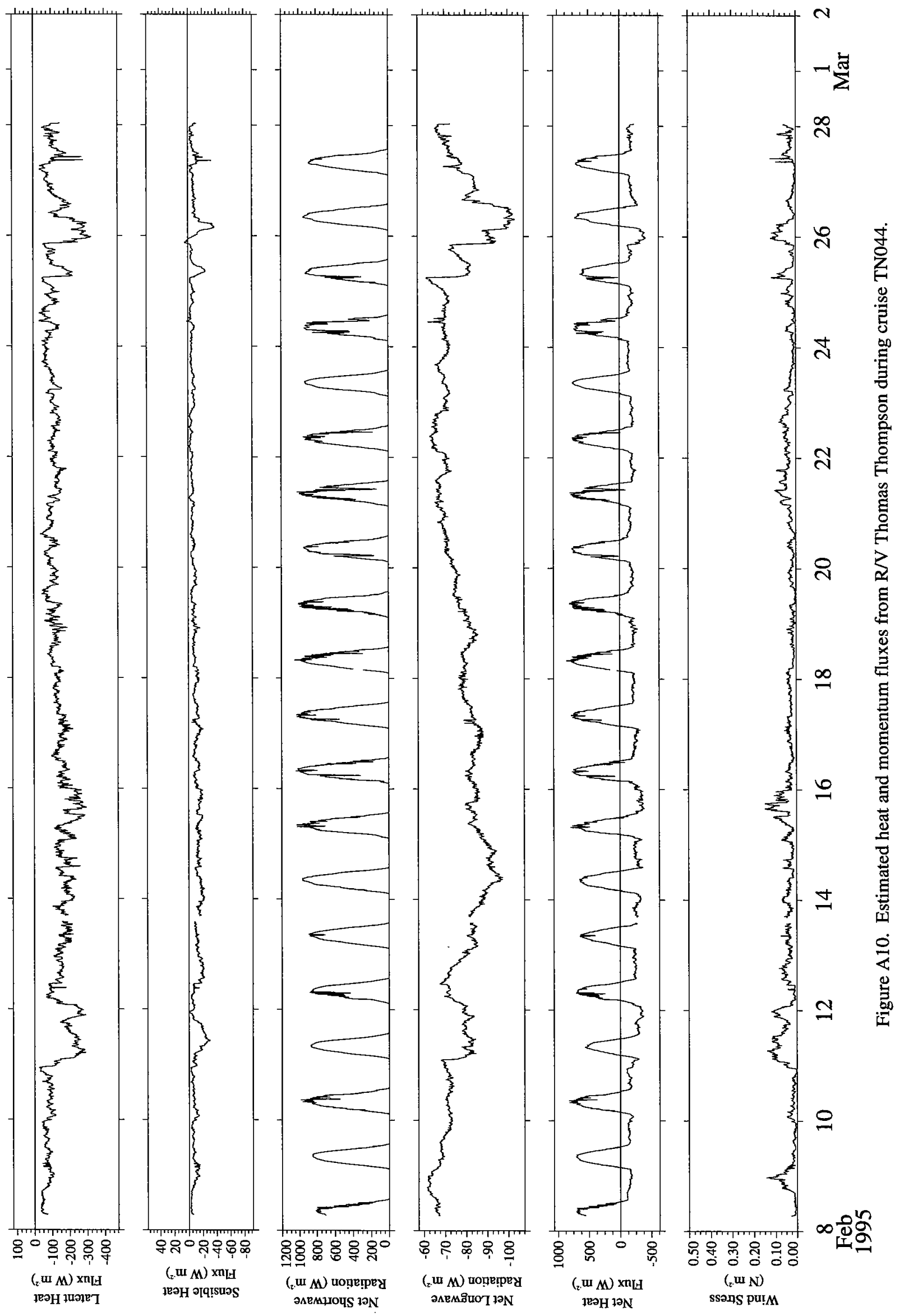



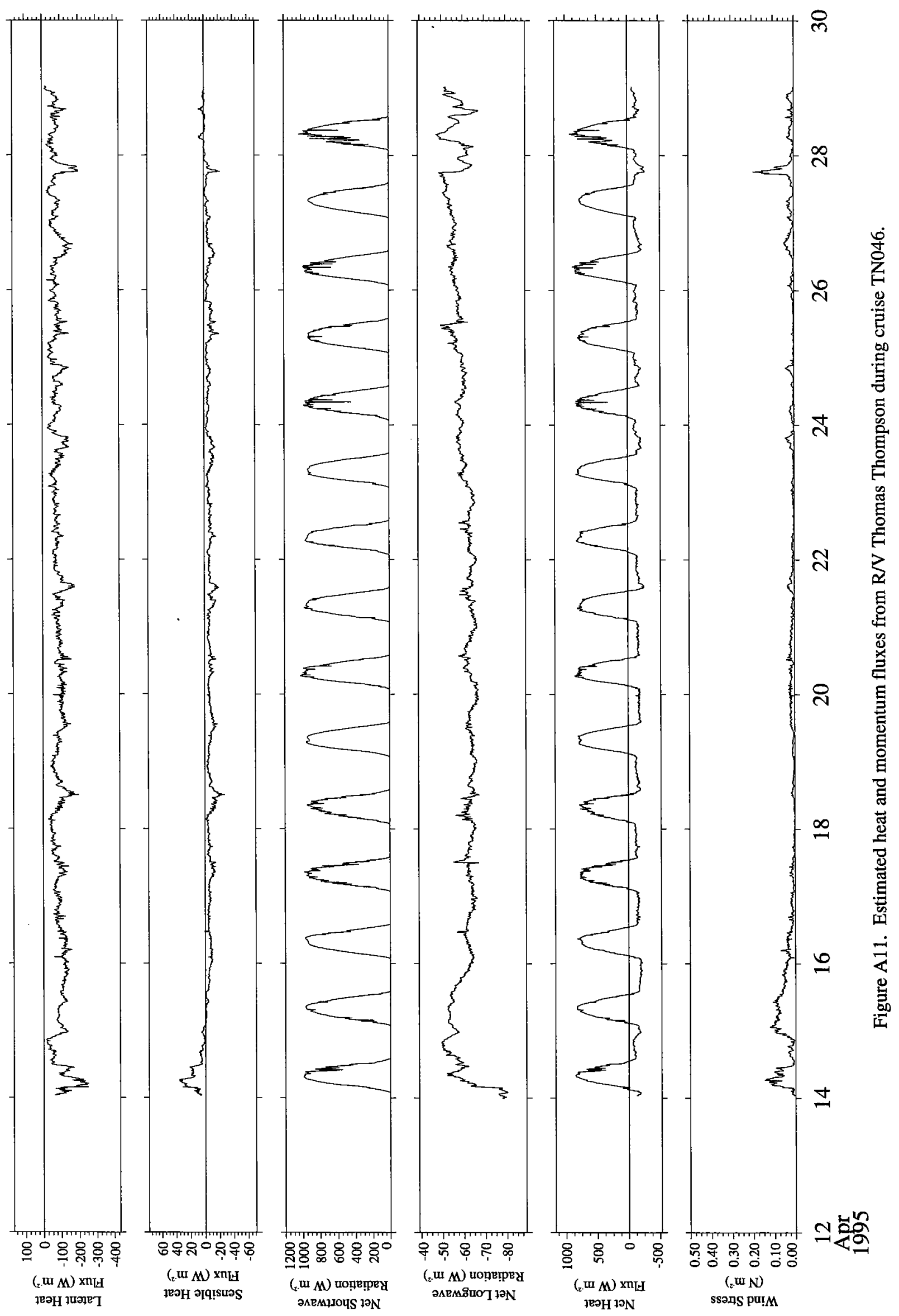


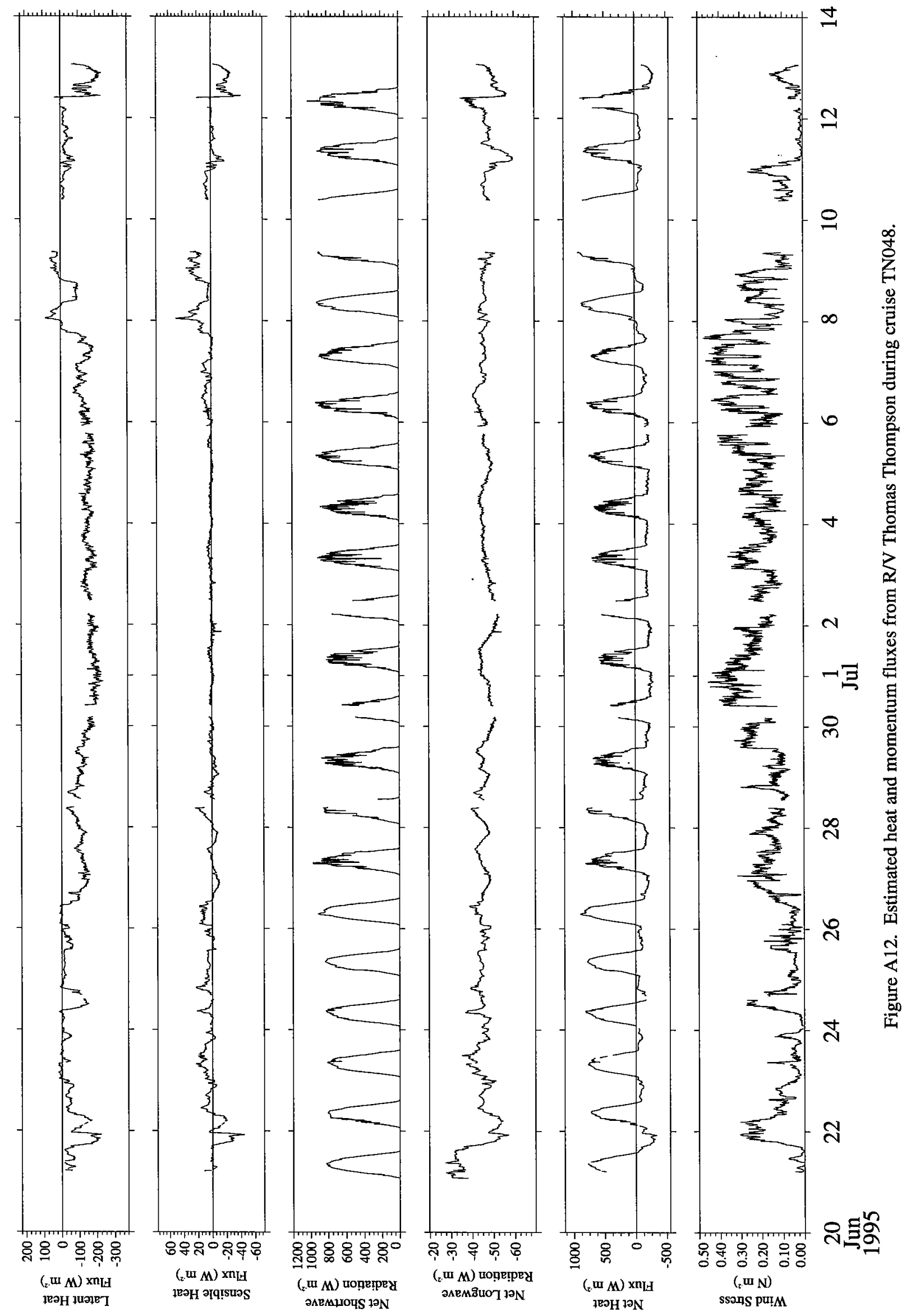




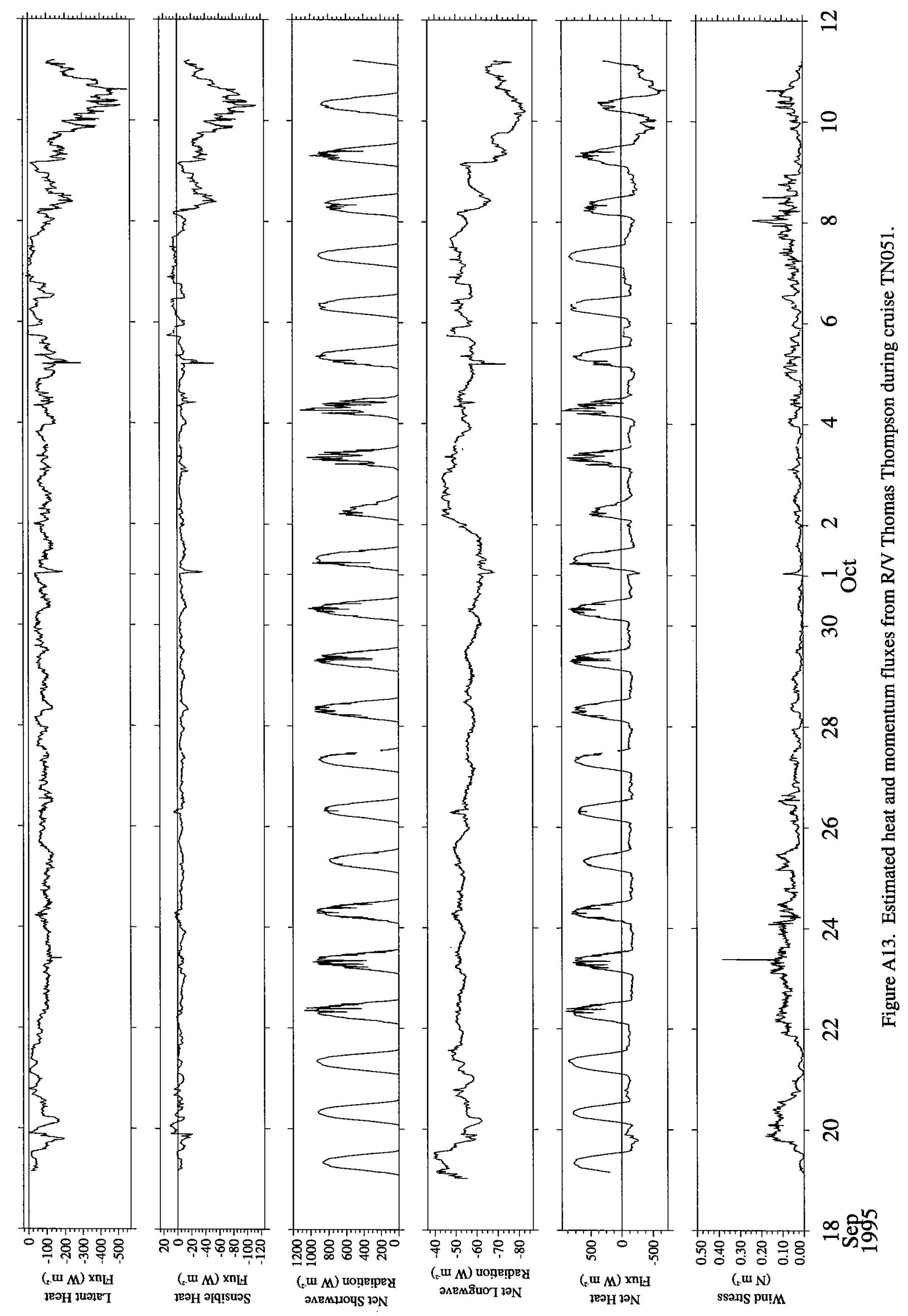




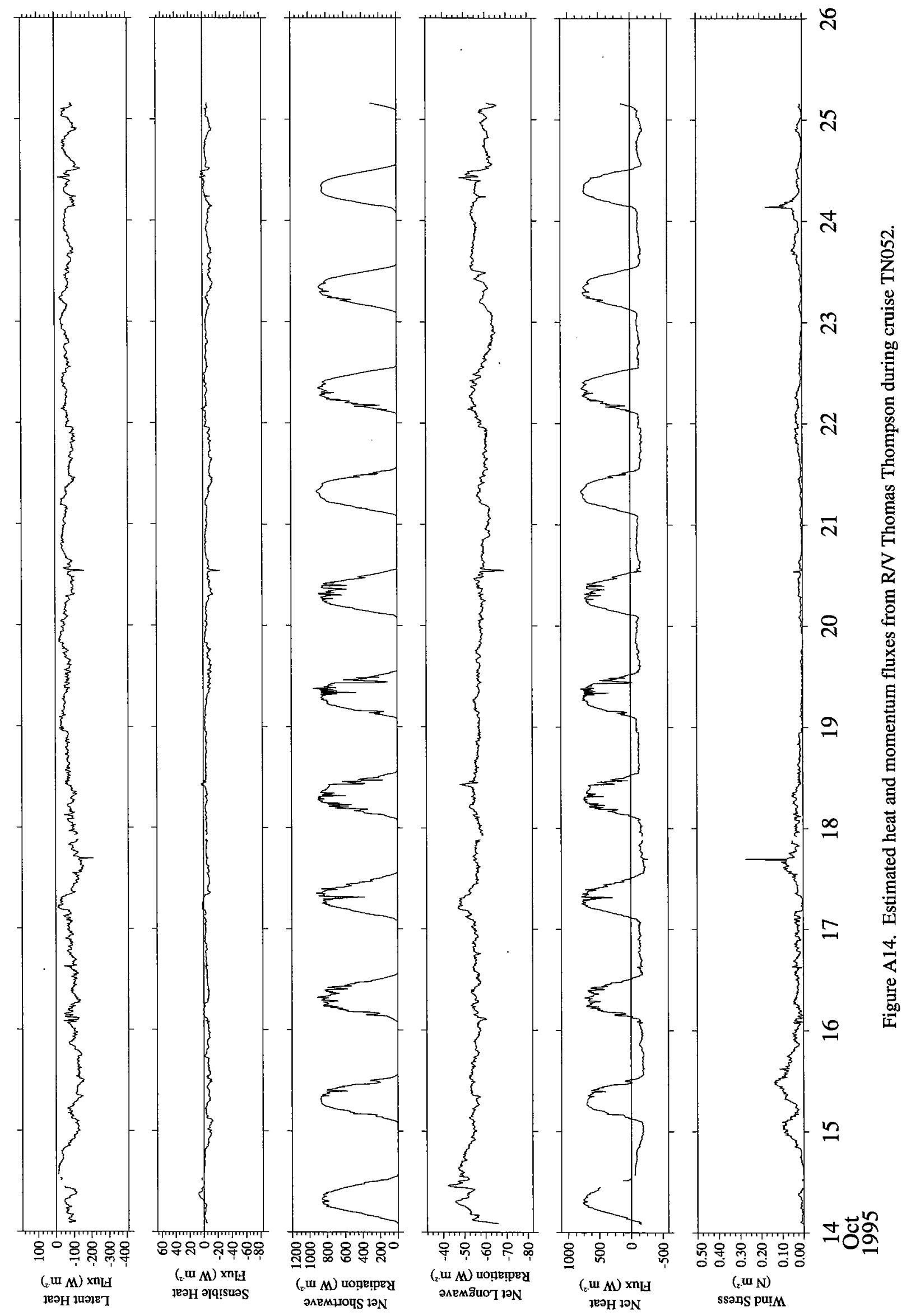



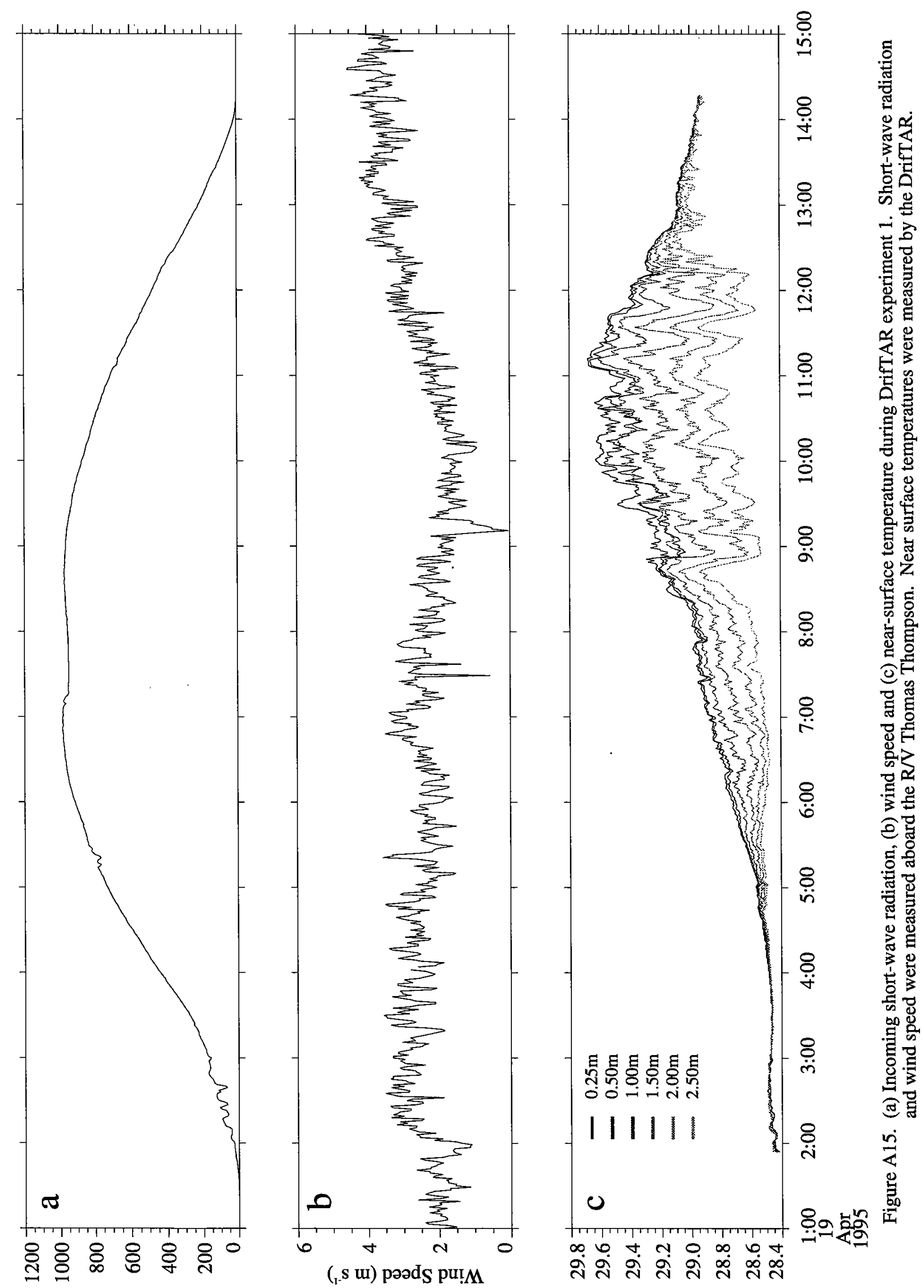

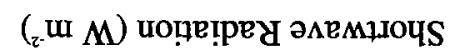




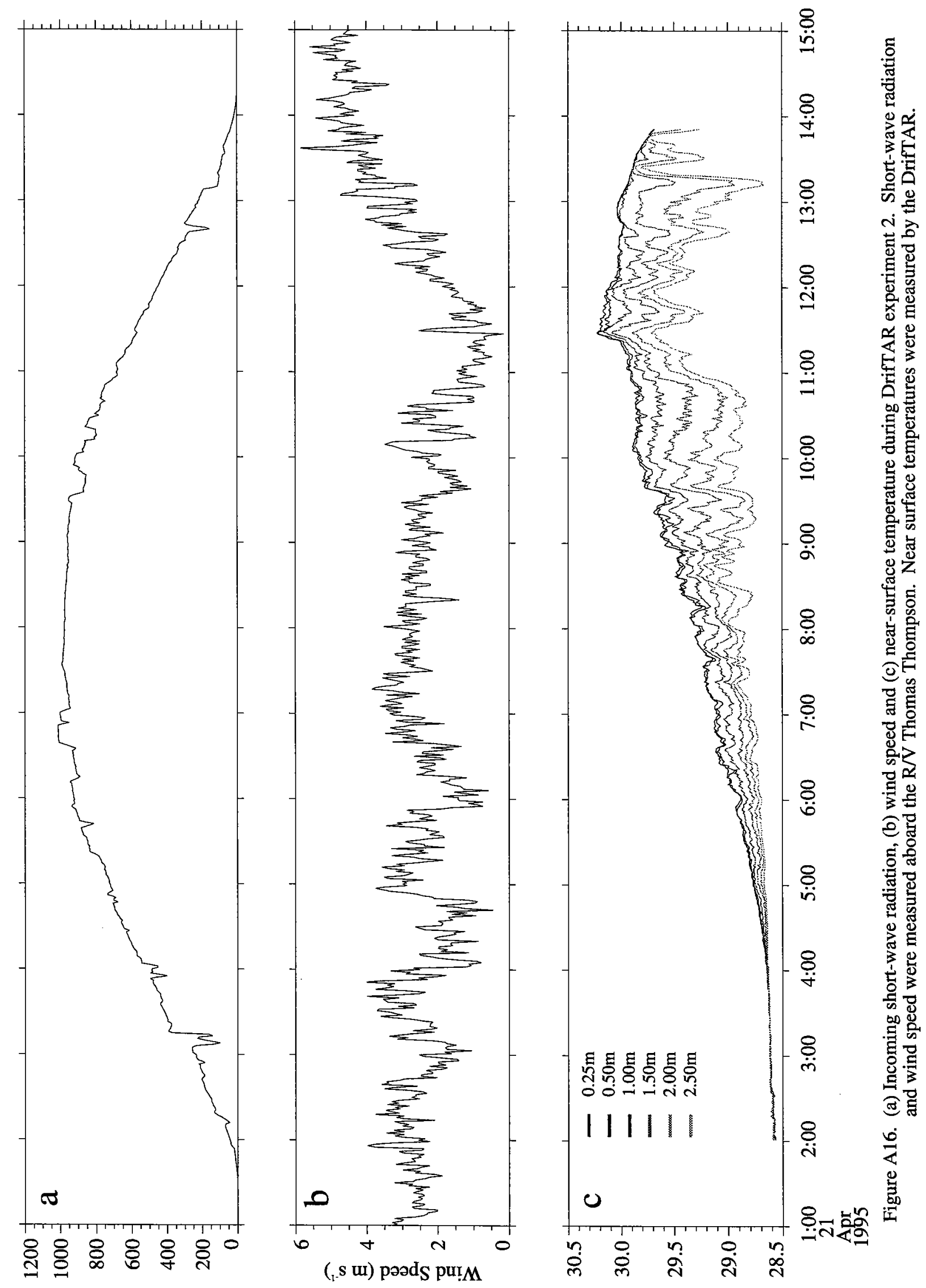

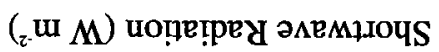




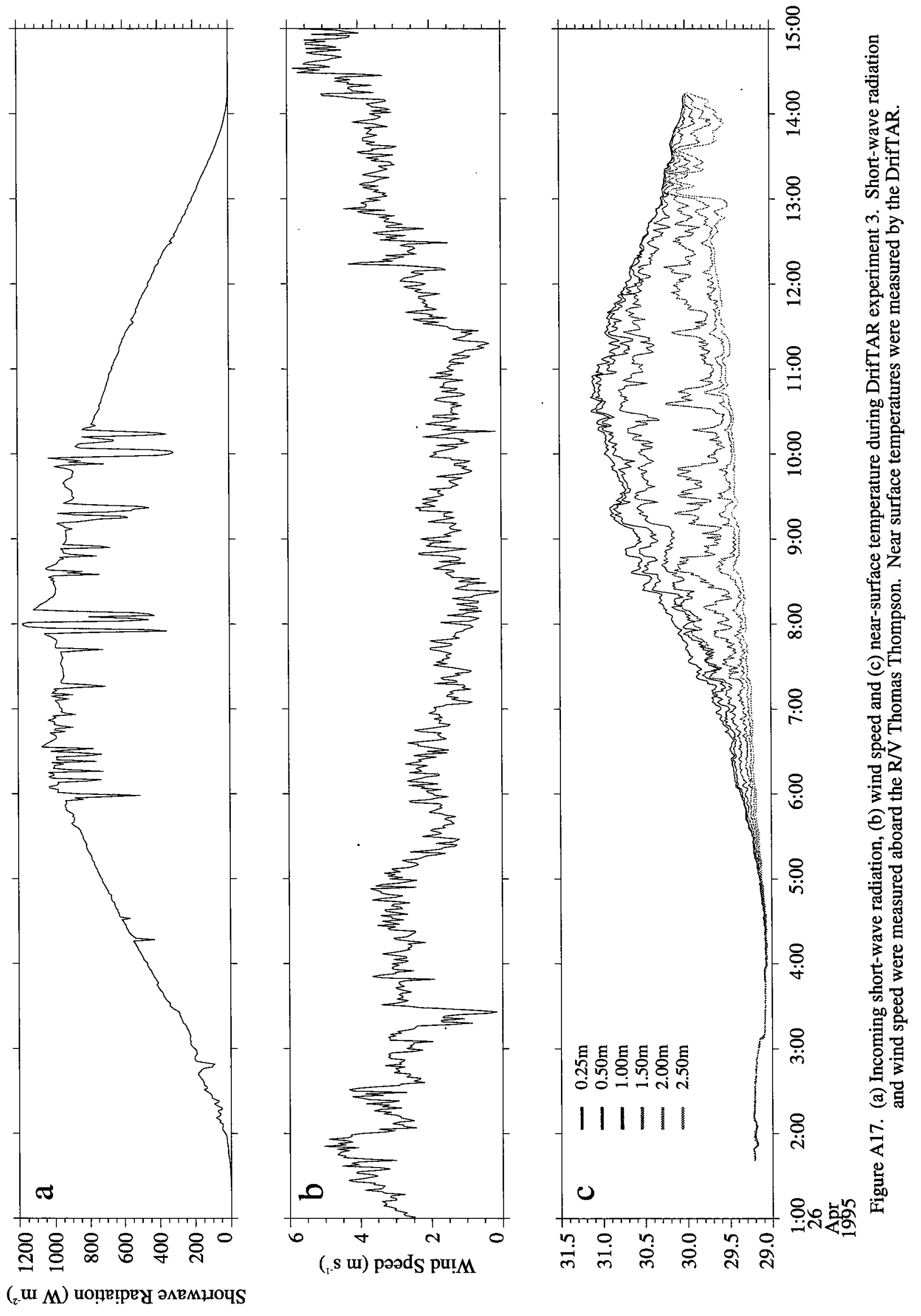



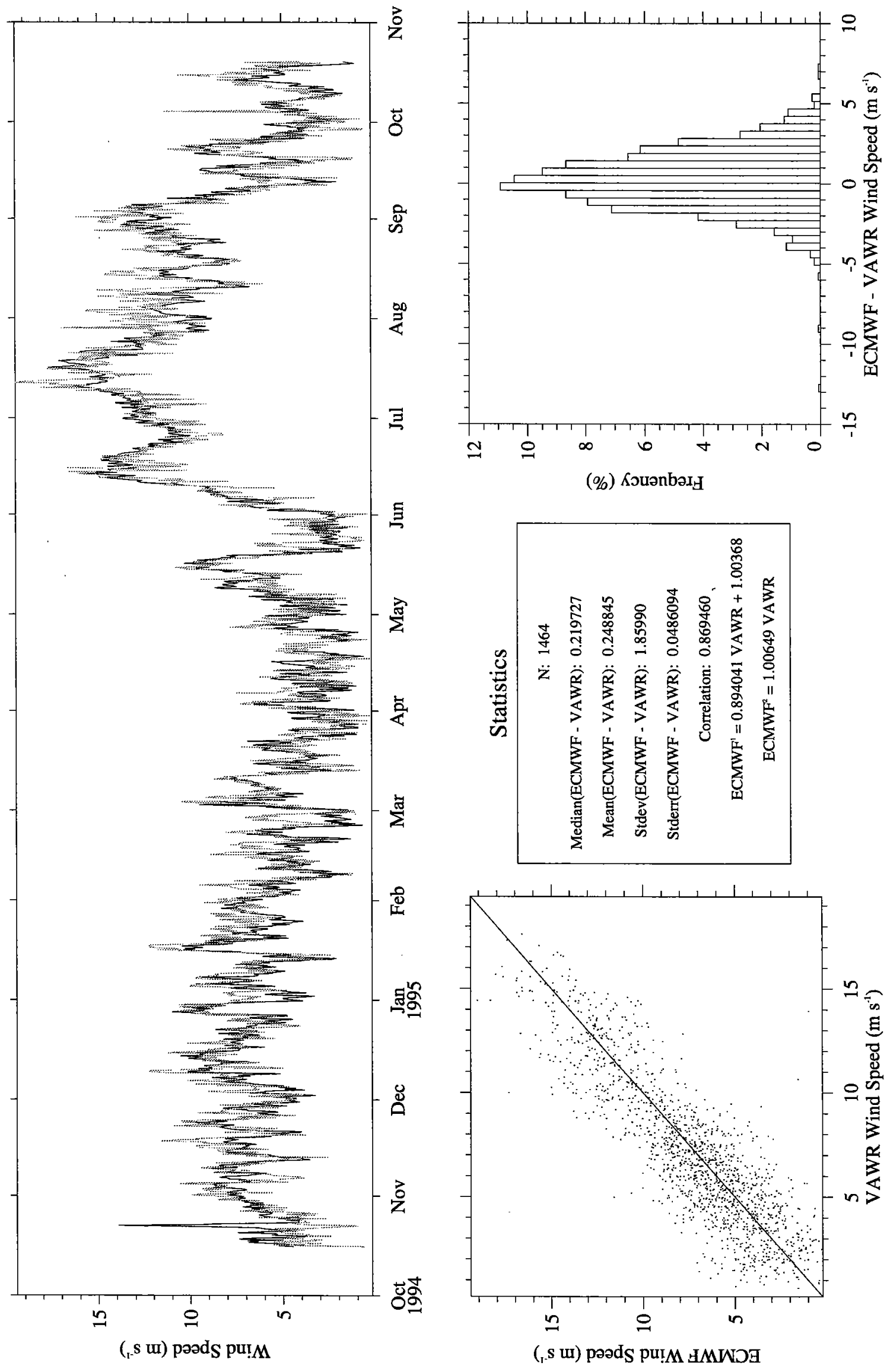

年

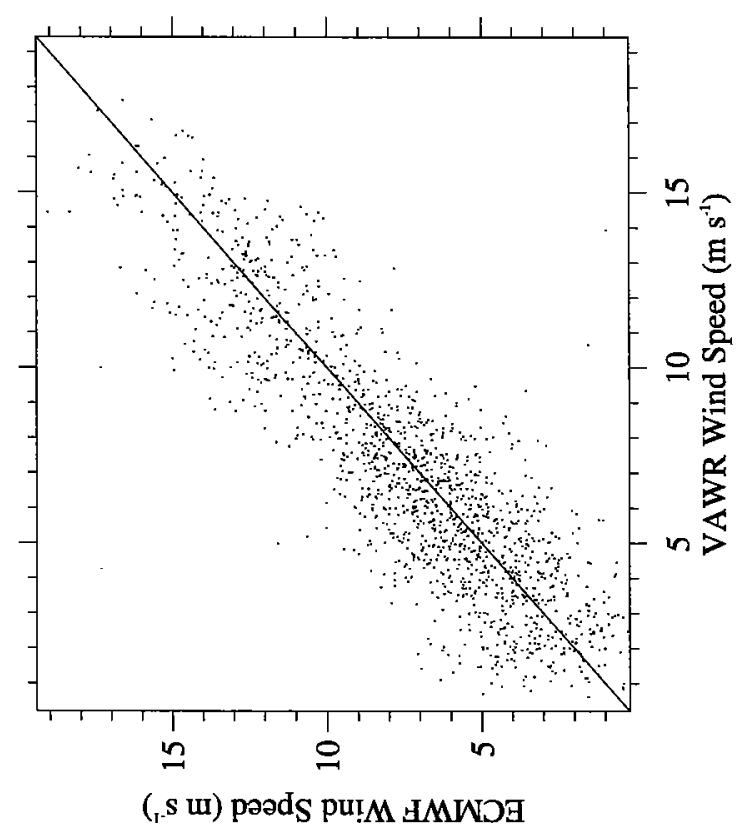



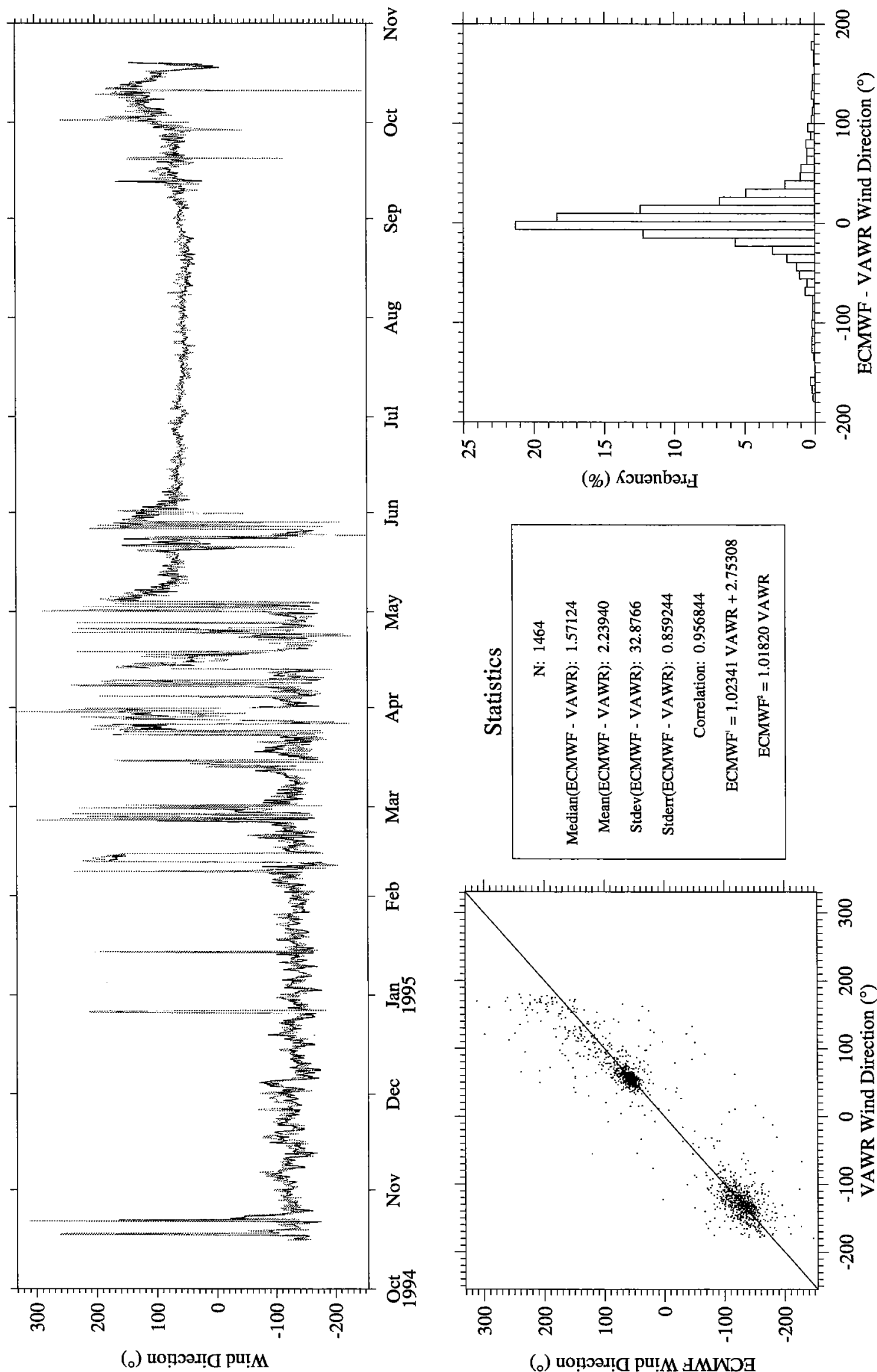

(\%) Кэuənbəג

总

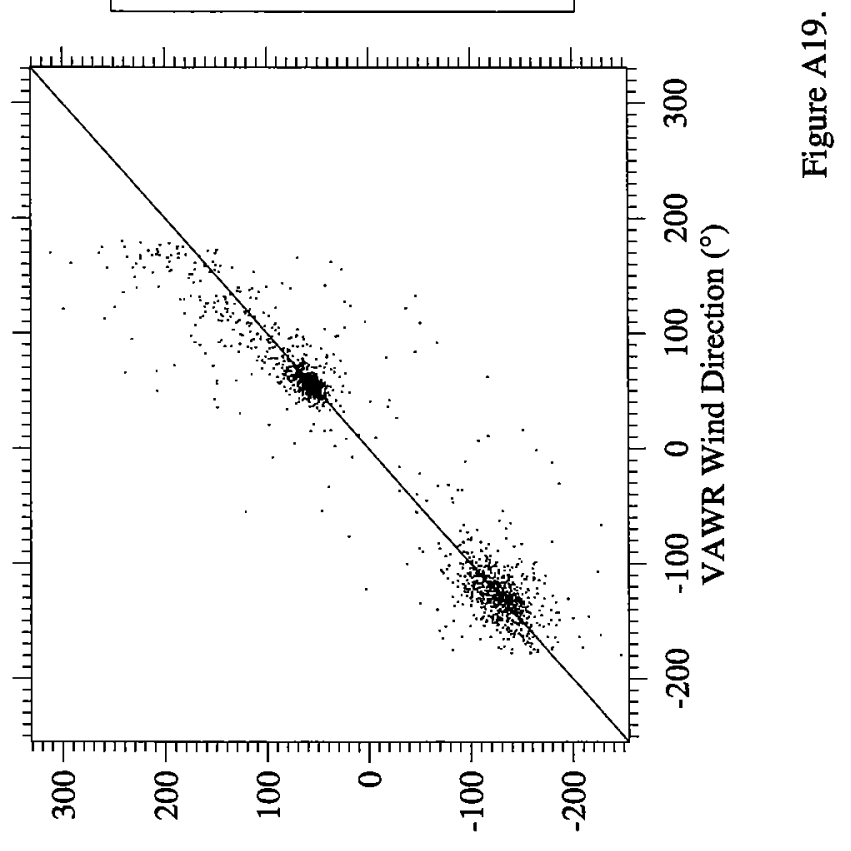



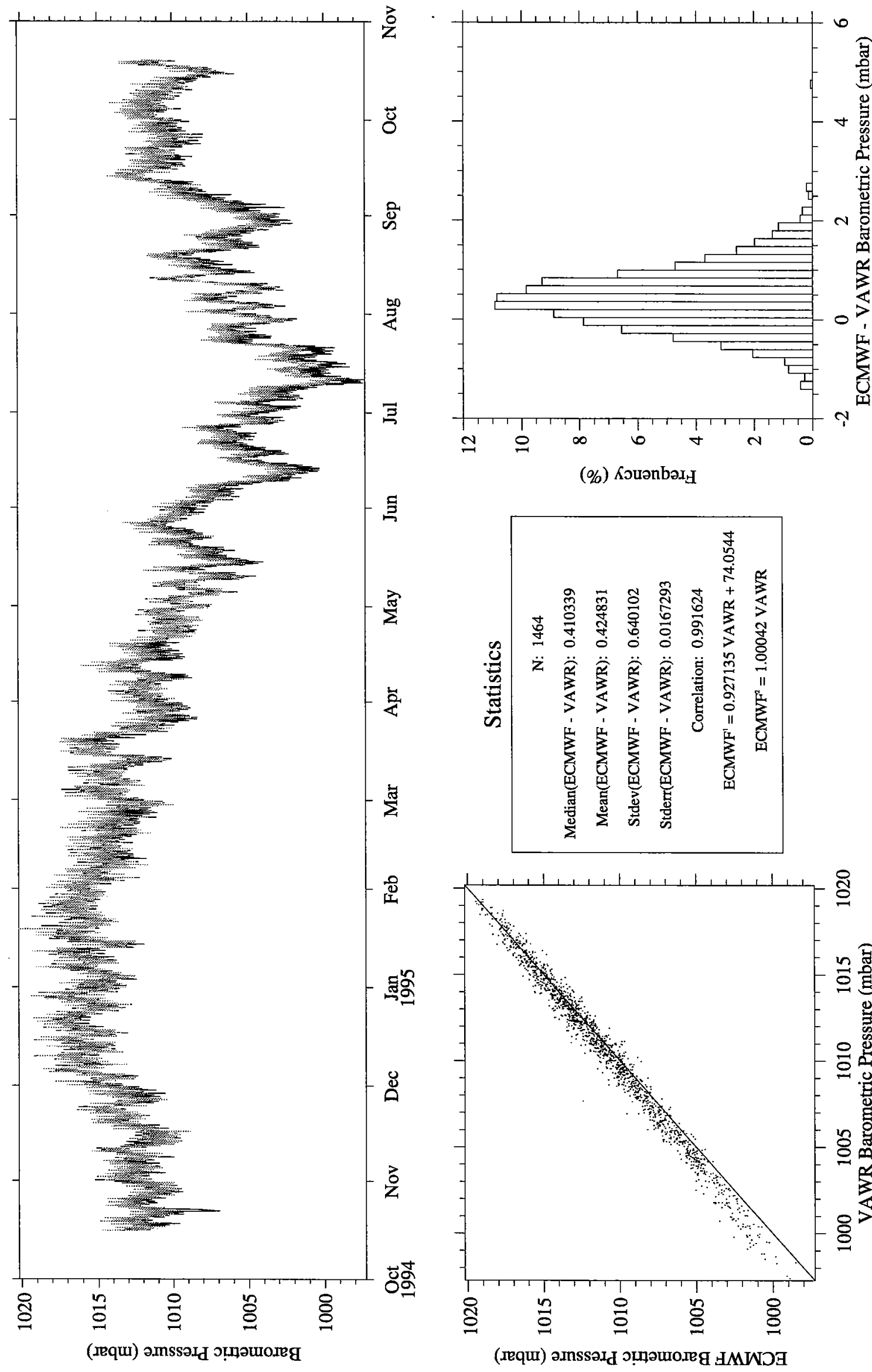

目

吾
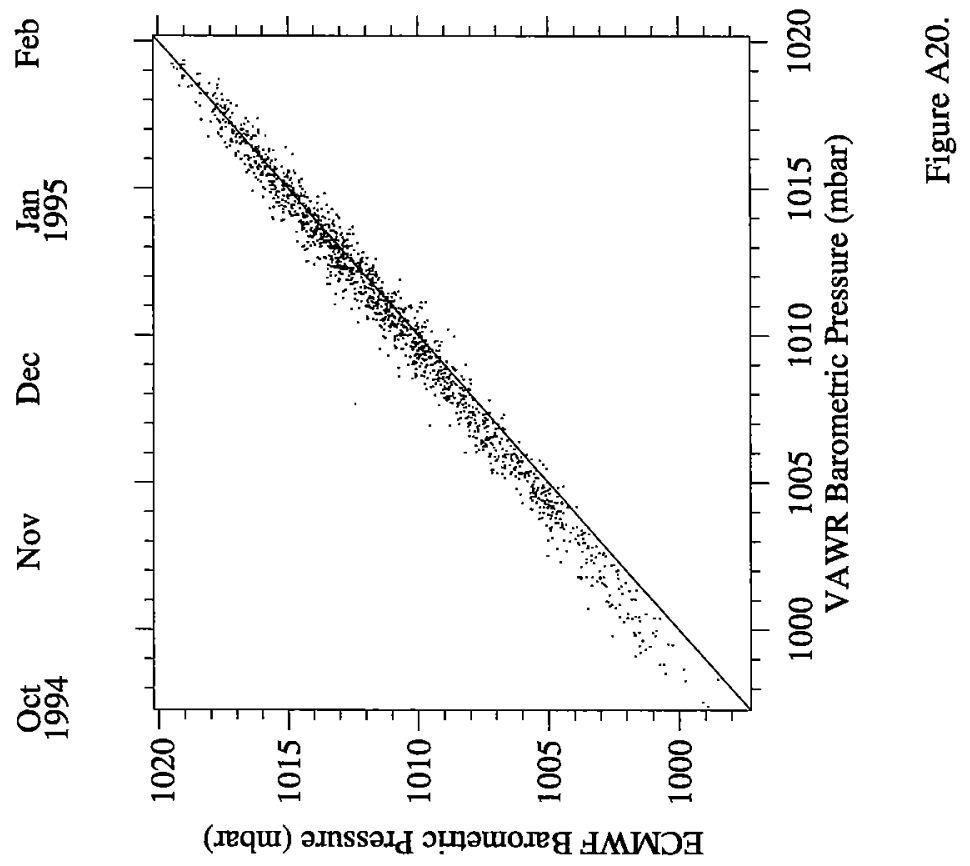

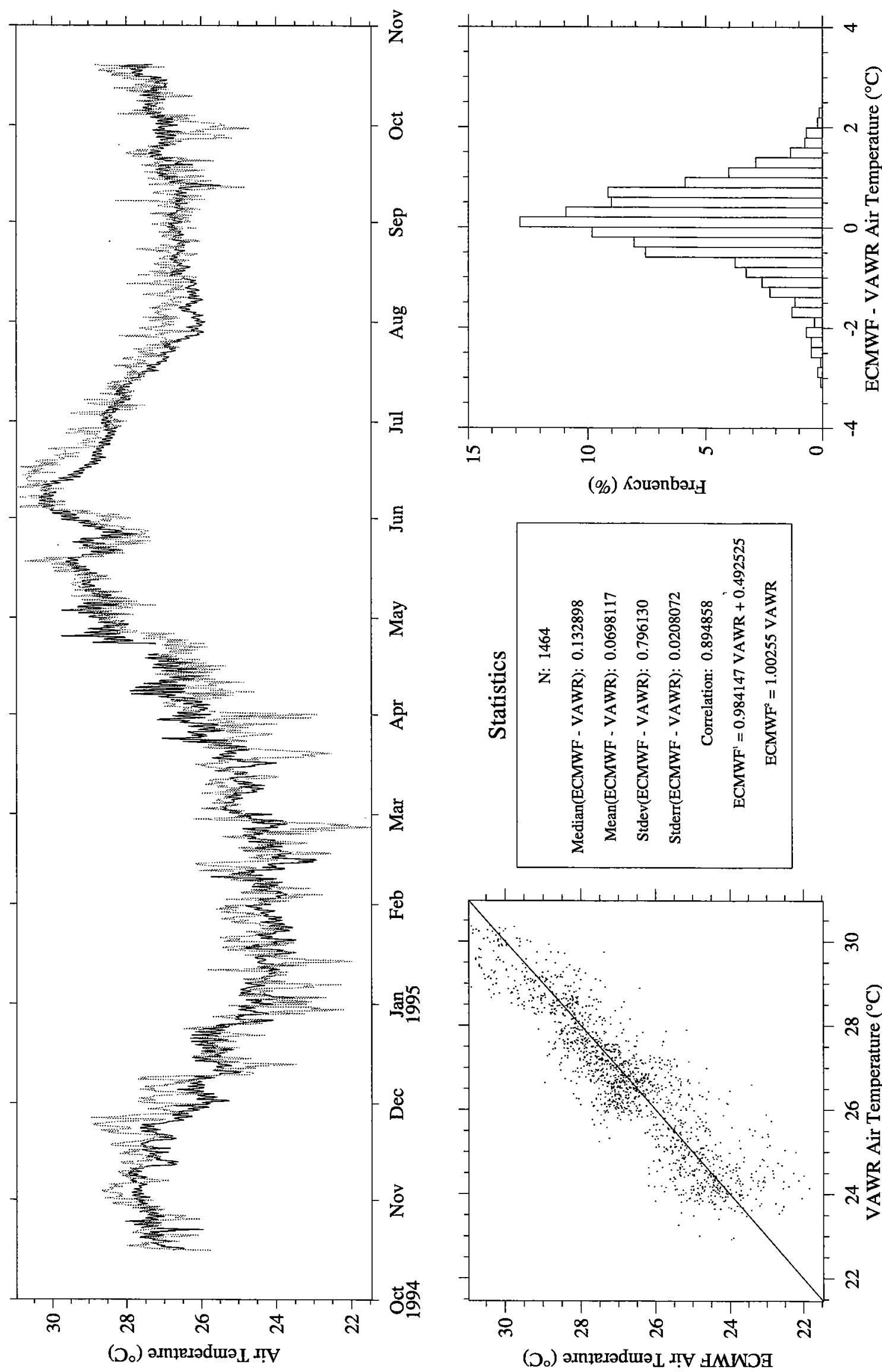

(\%) KouənbəxH
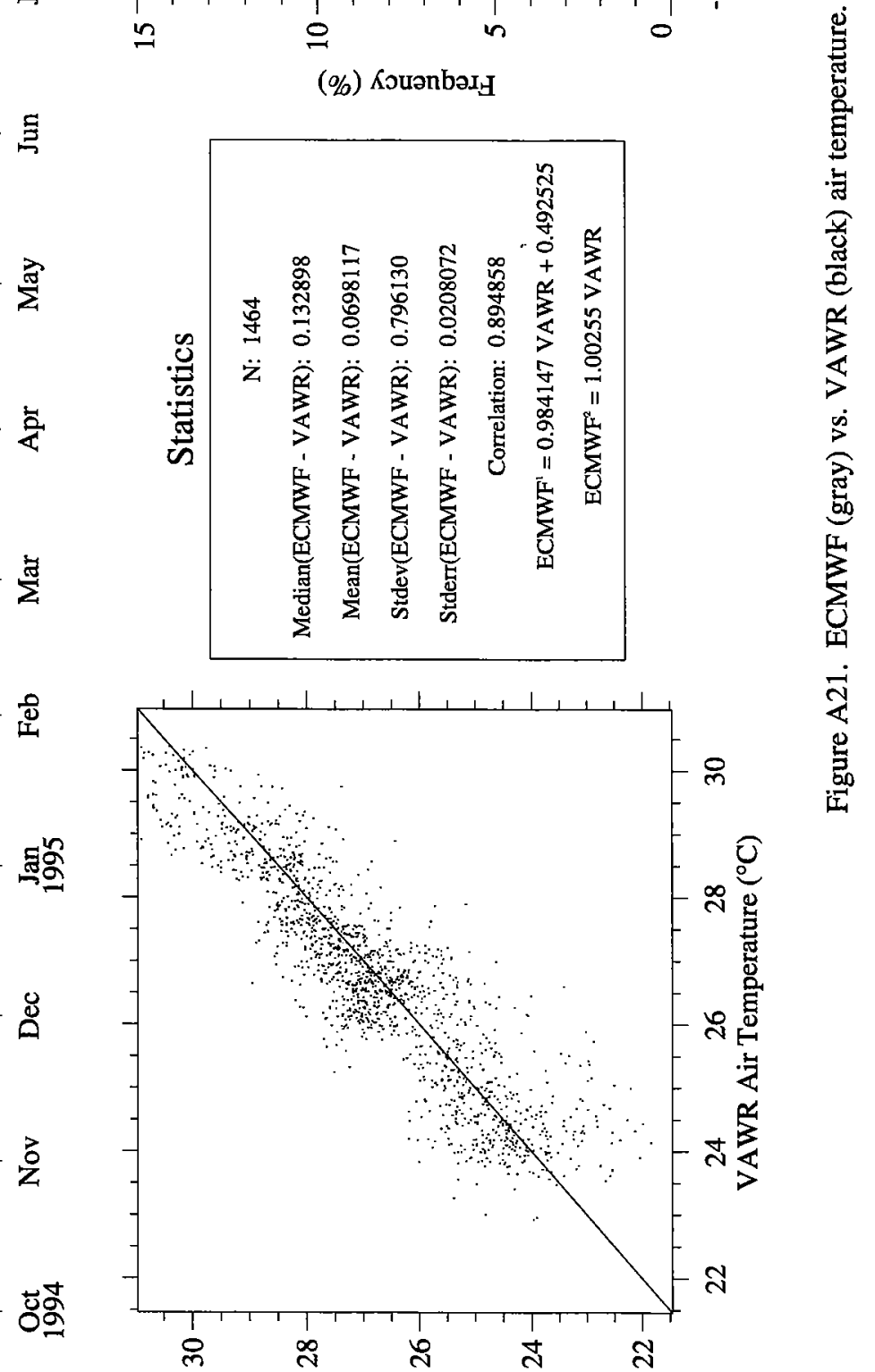


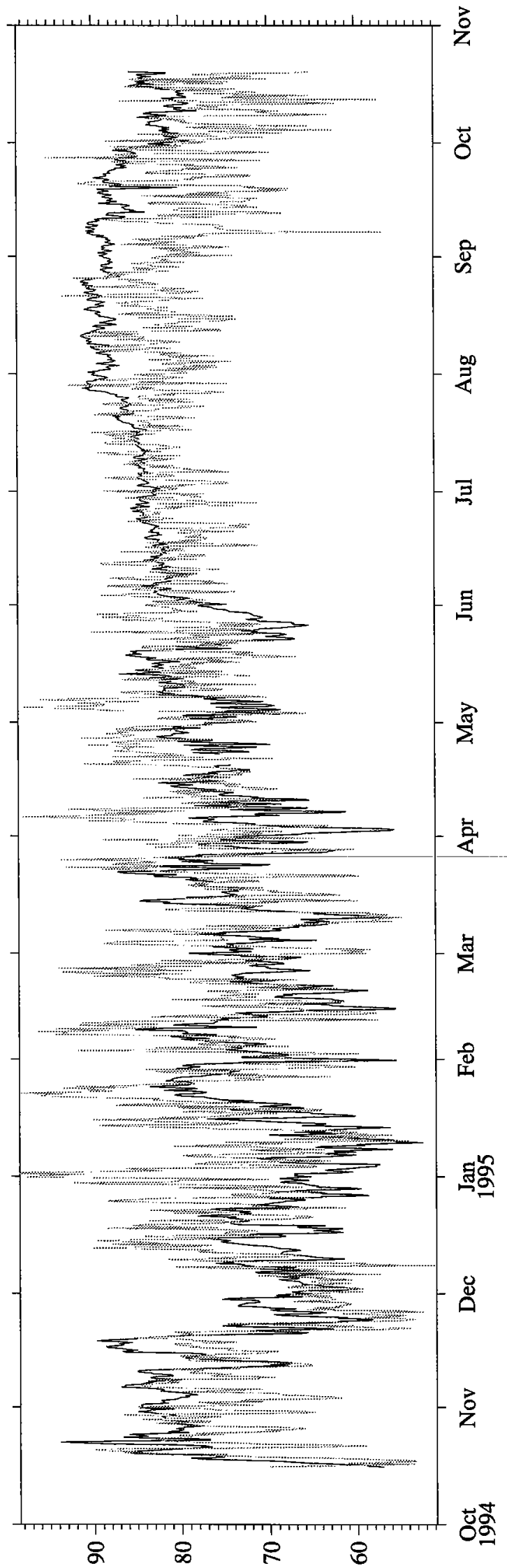

(\%) K?!̣!̣un

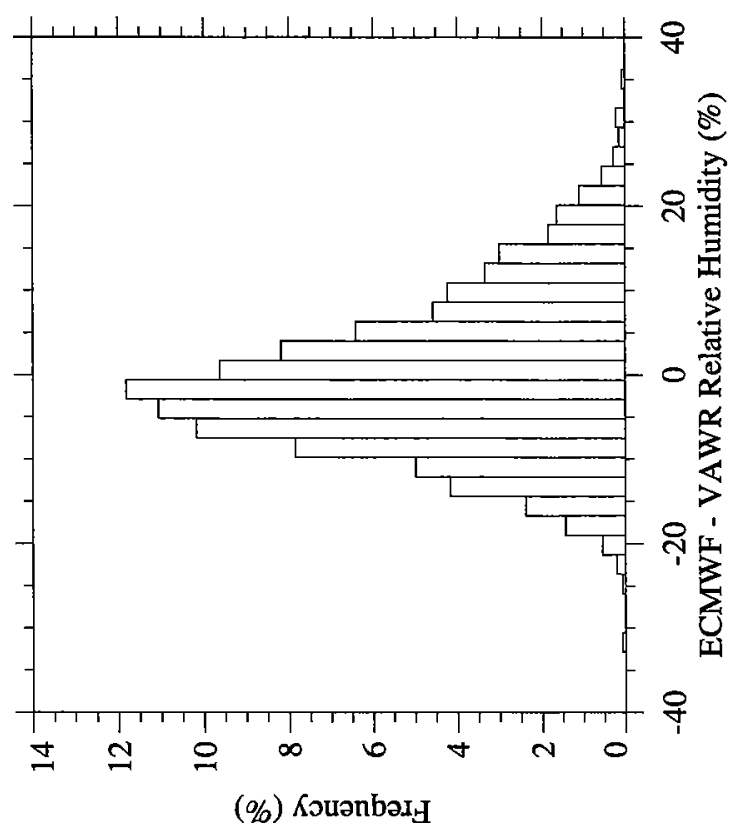

(\%) KouanbaxH
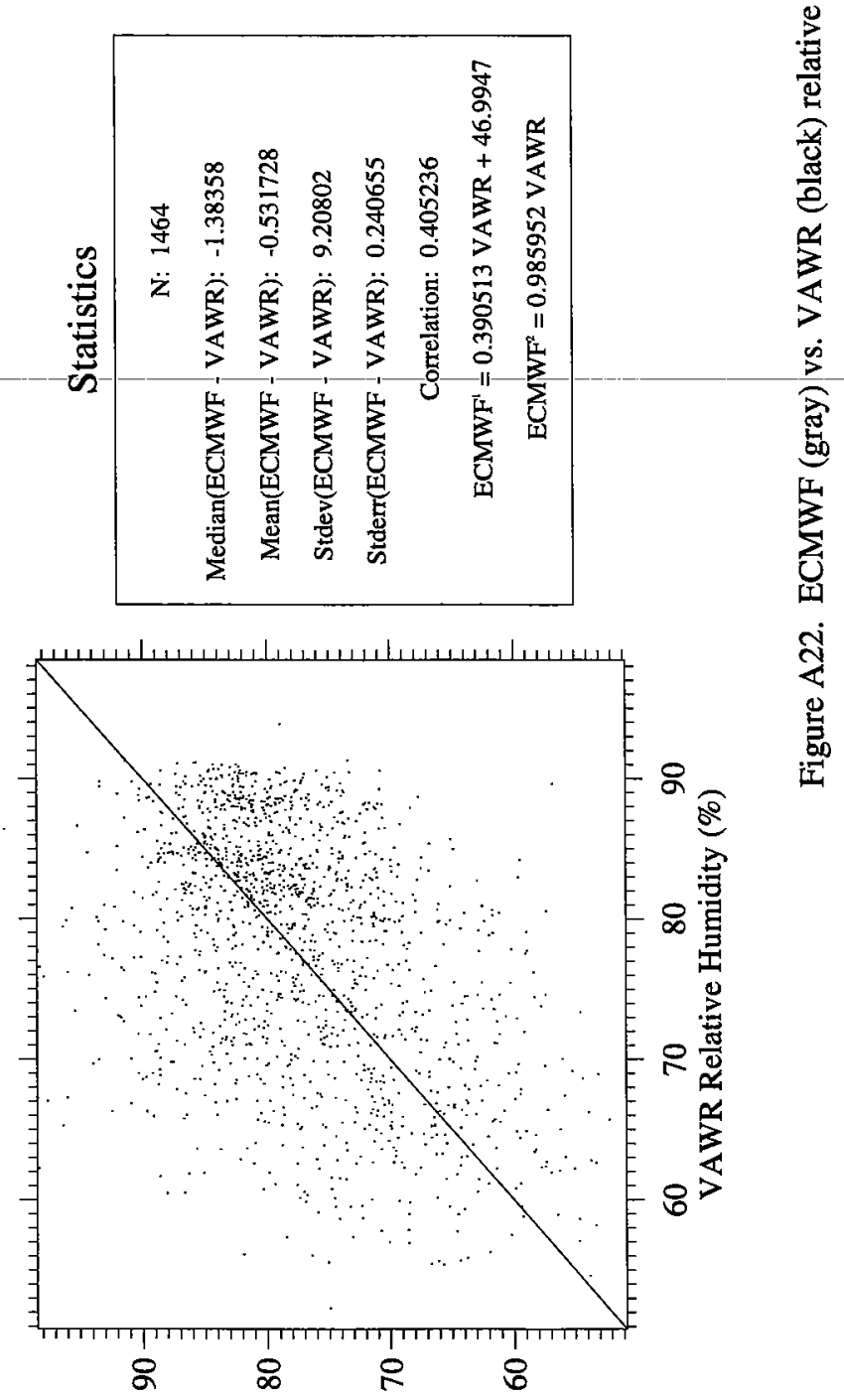

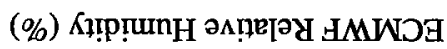



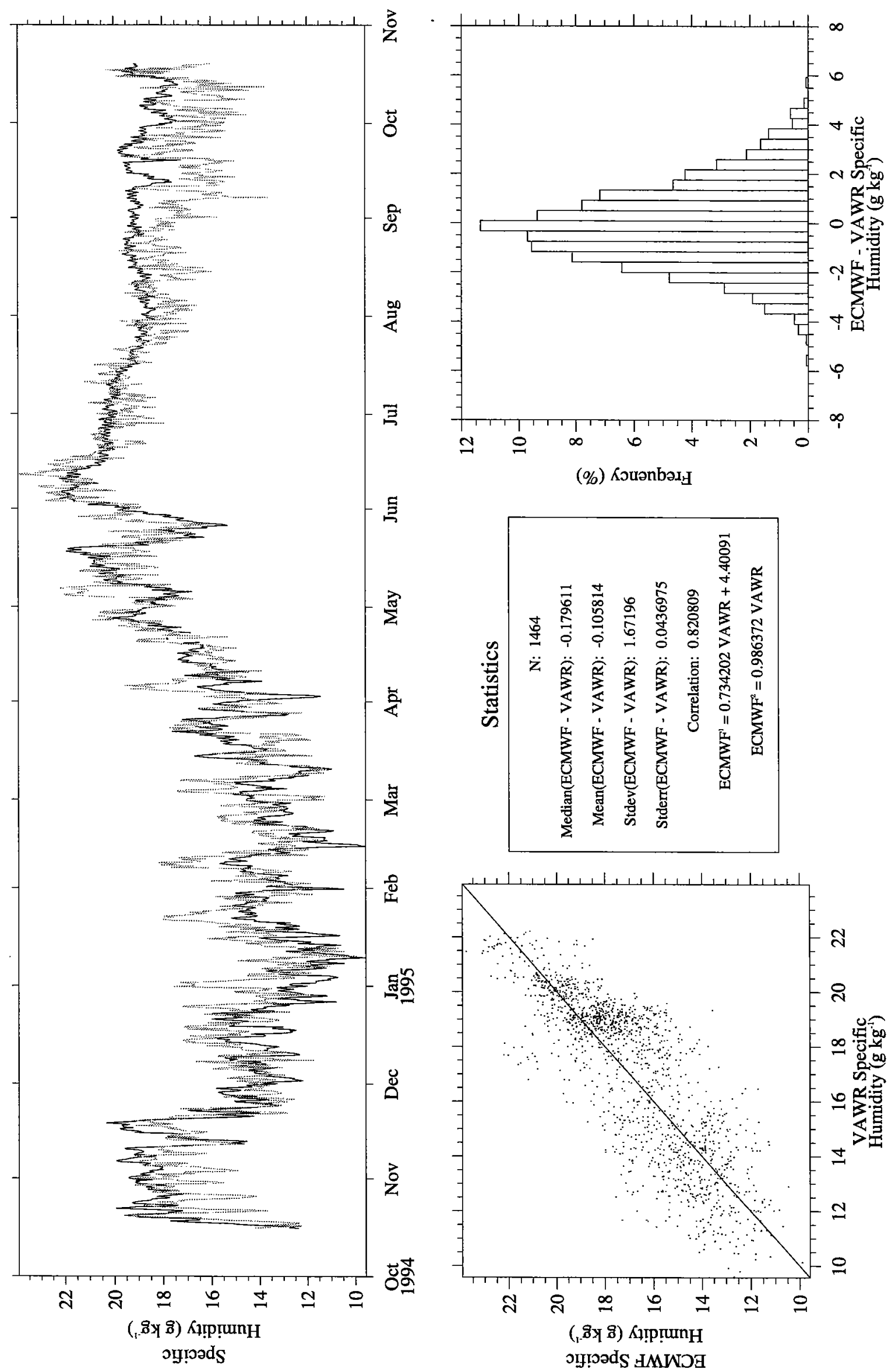

(\%) Кэuənbəג

章

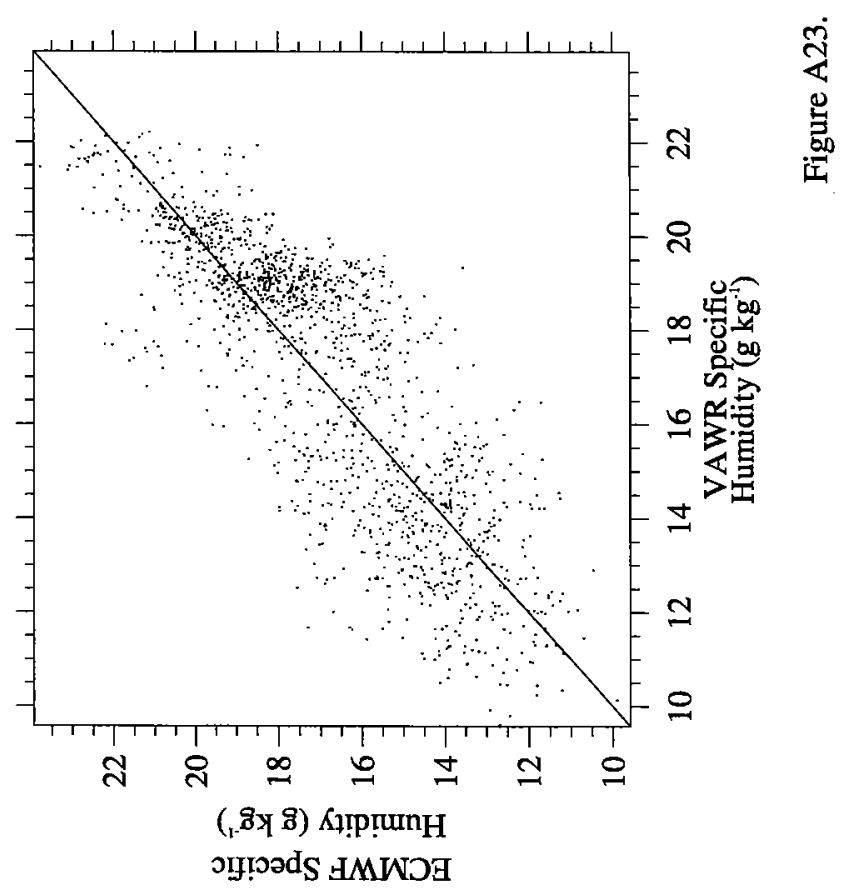




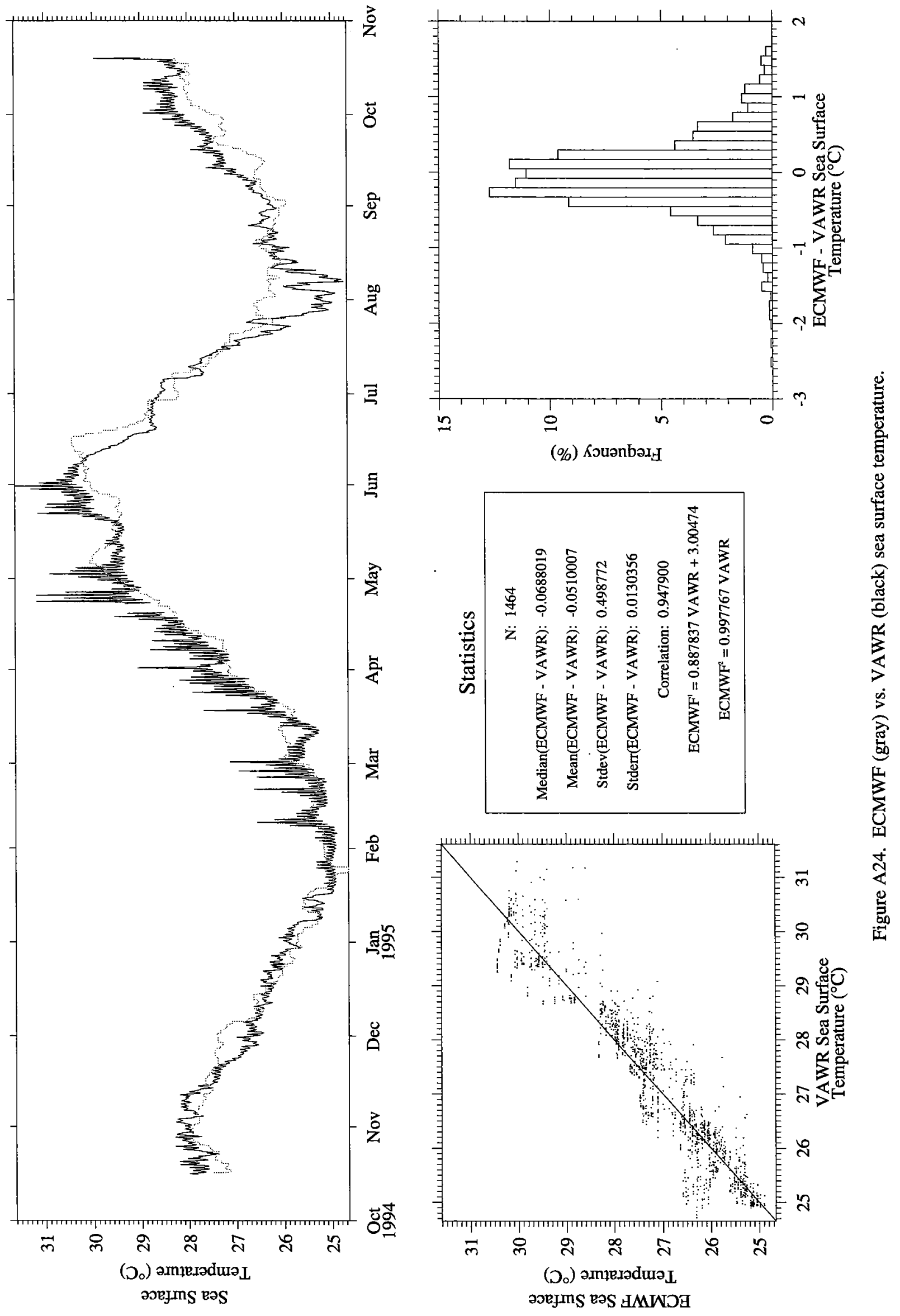



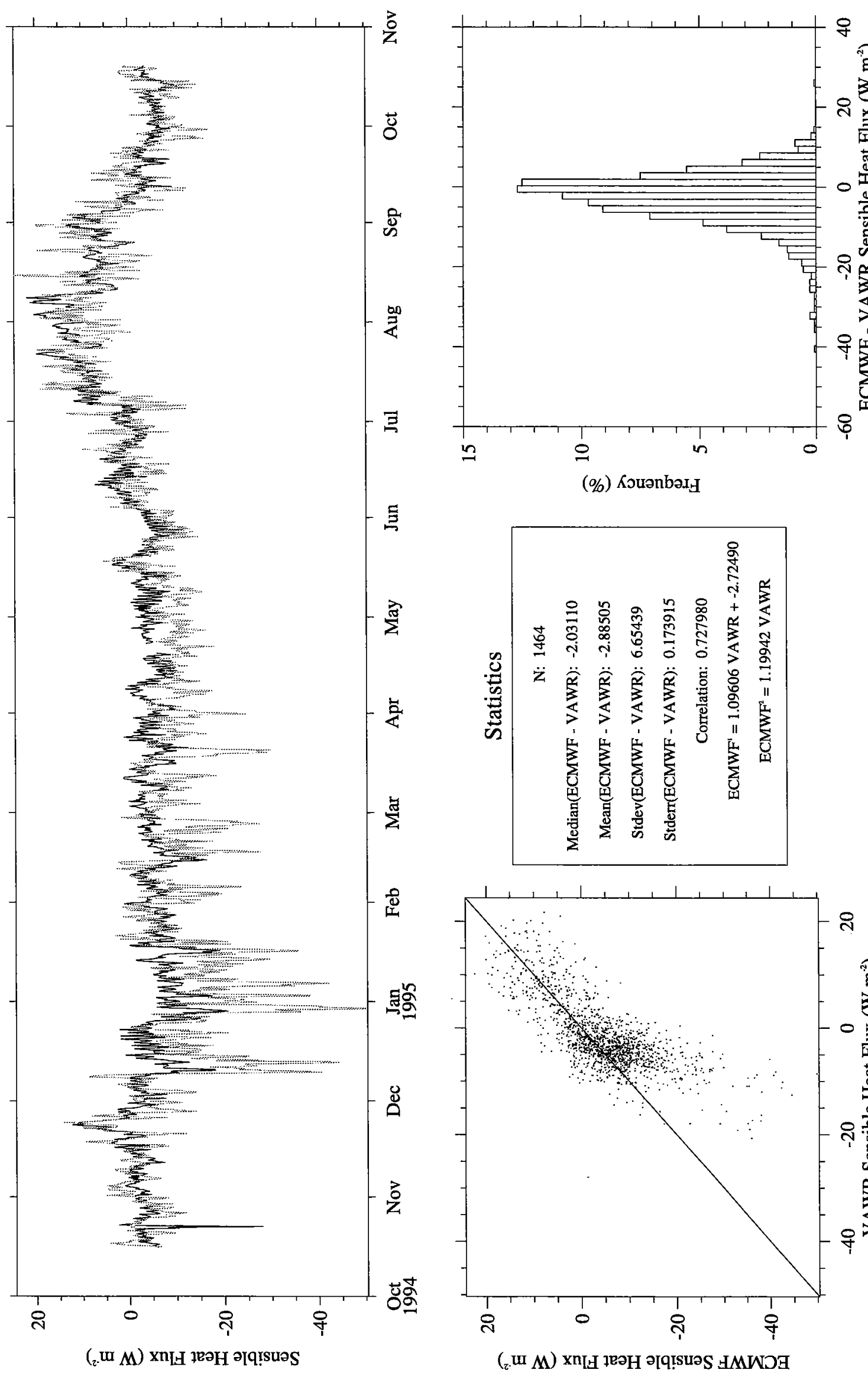

焉

운

(\%) Кэนәnbวد

吾

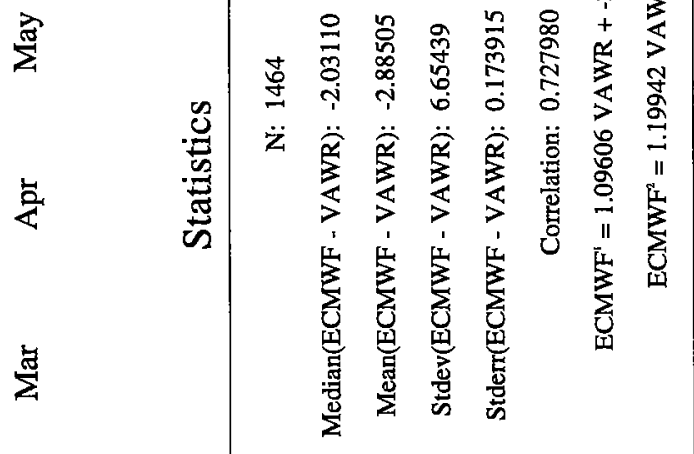

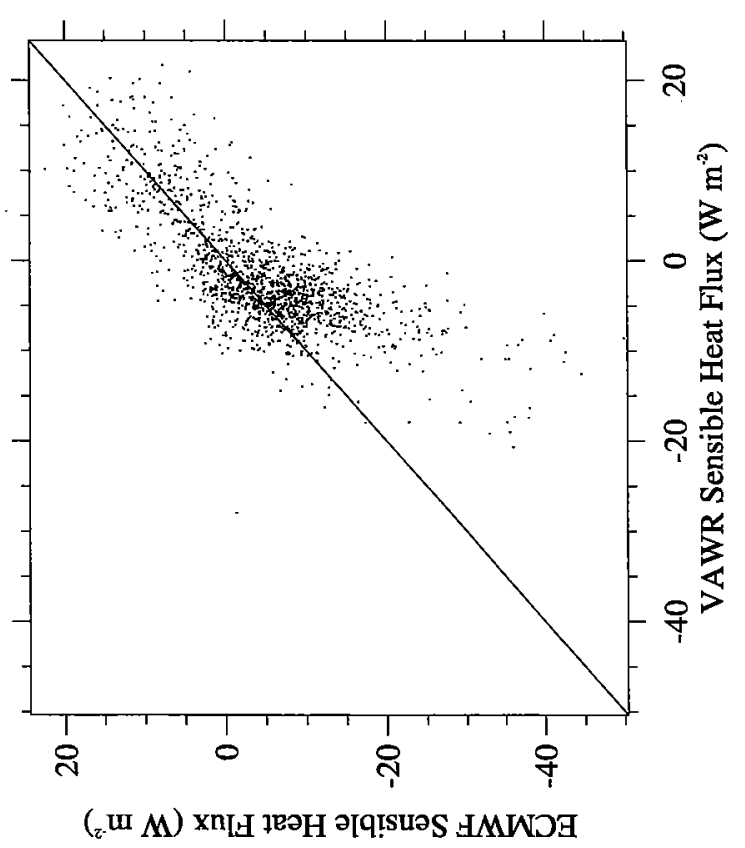

20 

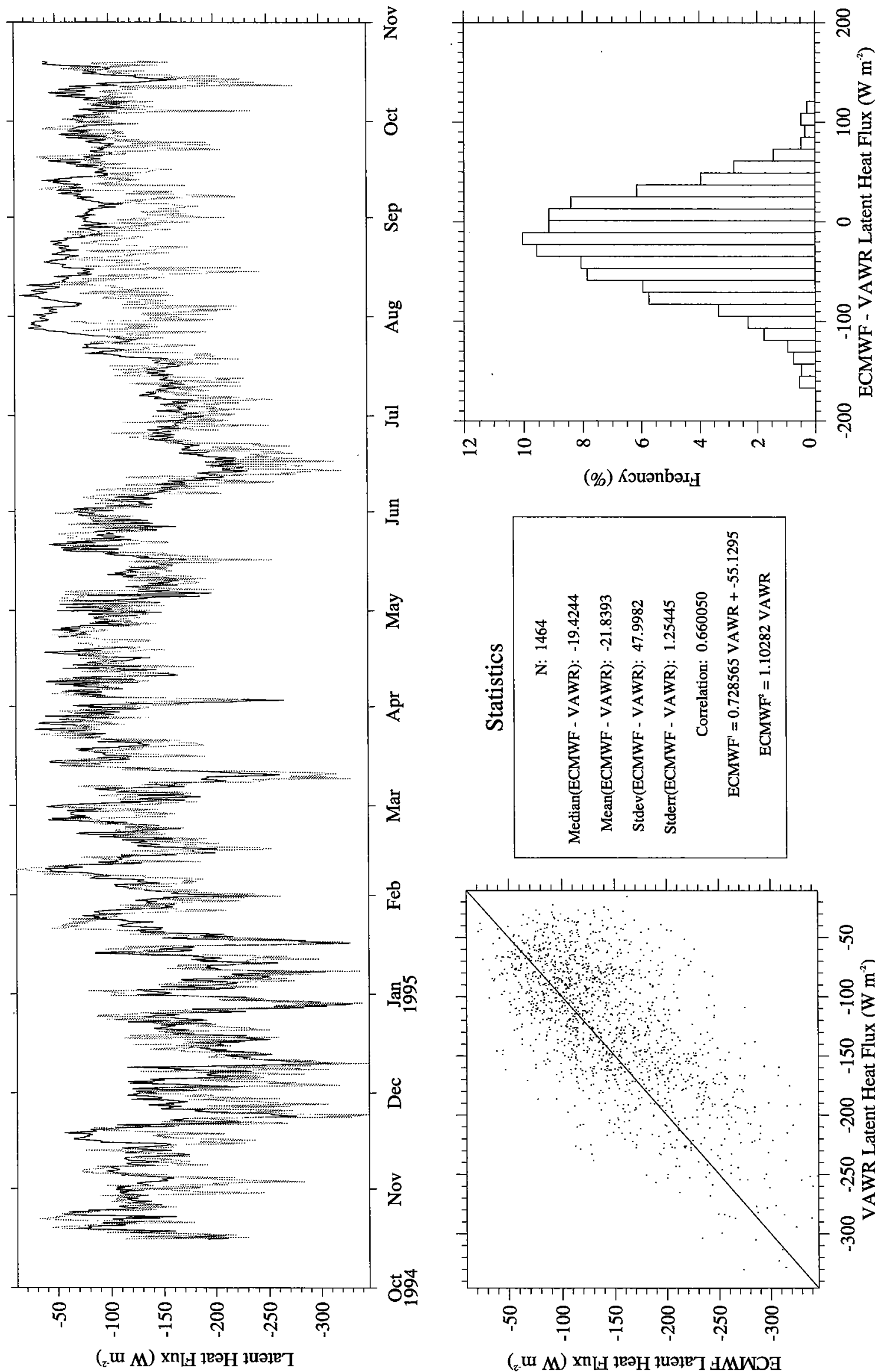

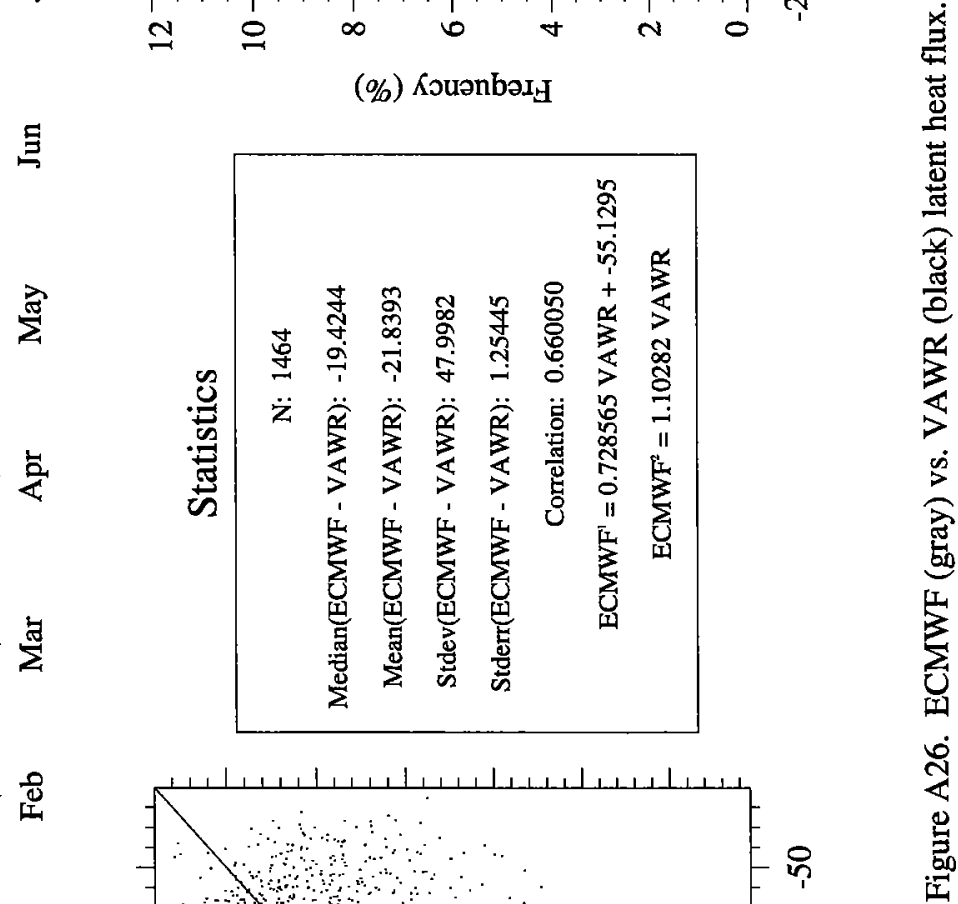

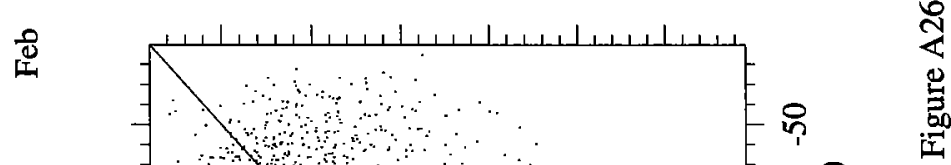

ตัดู

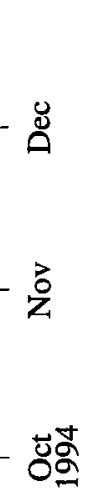

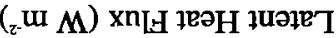



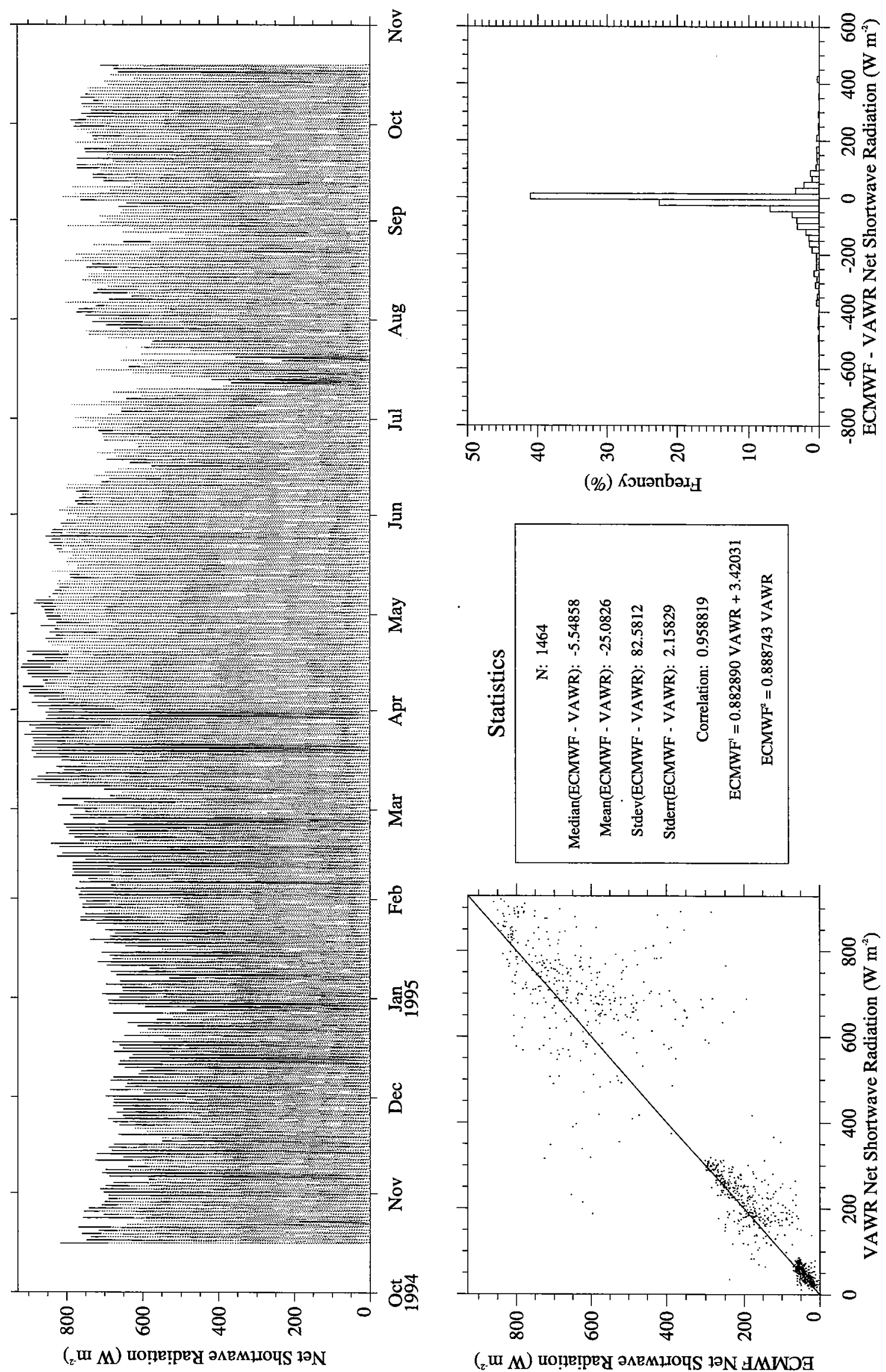

(\%) Кэuənbəد
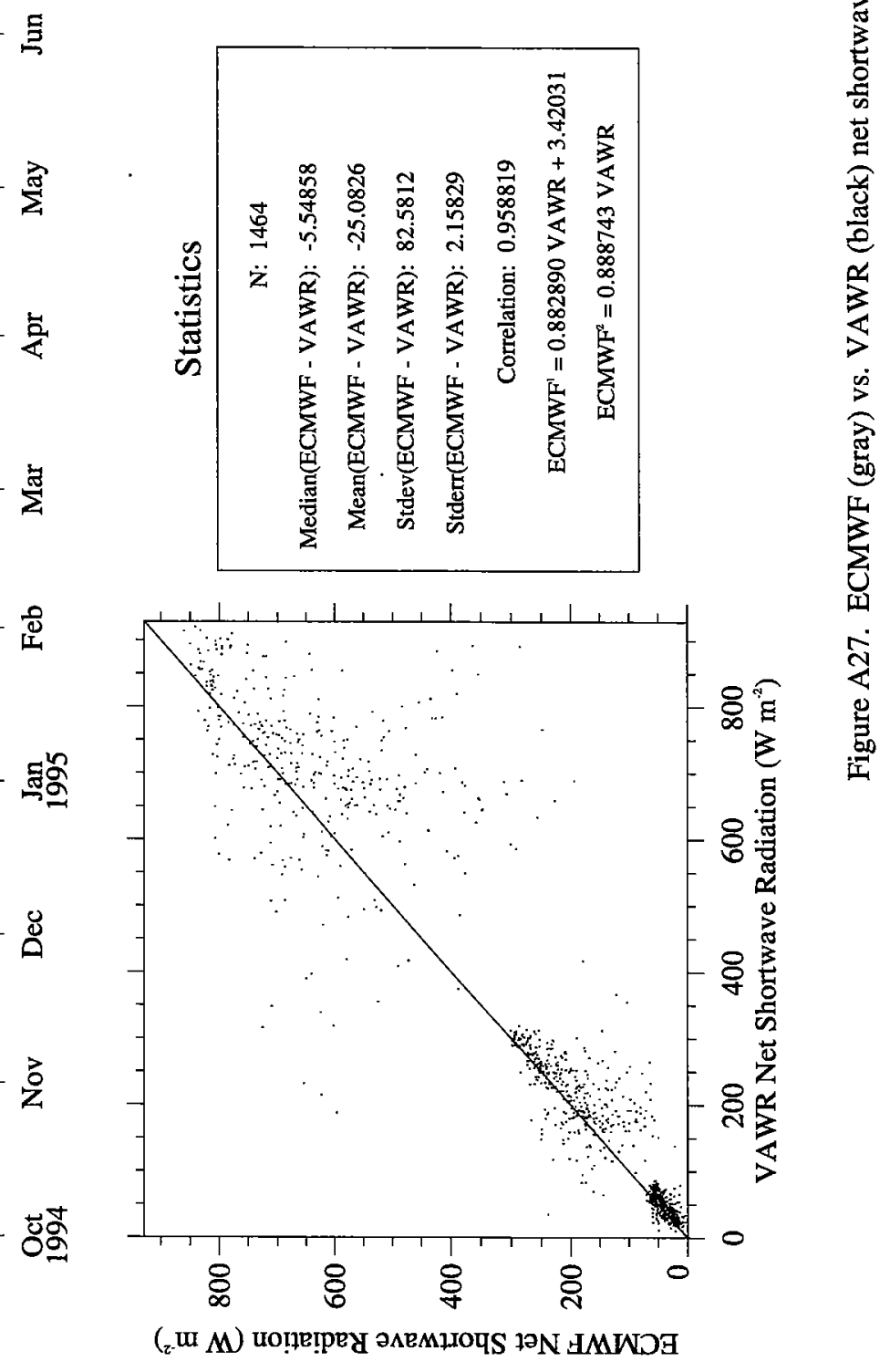


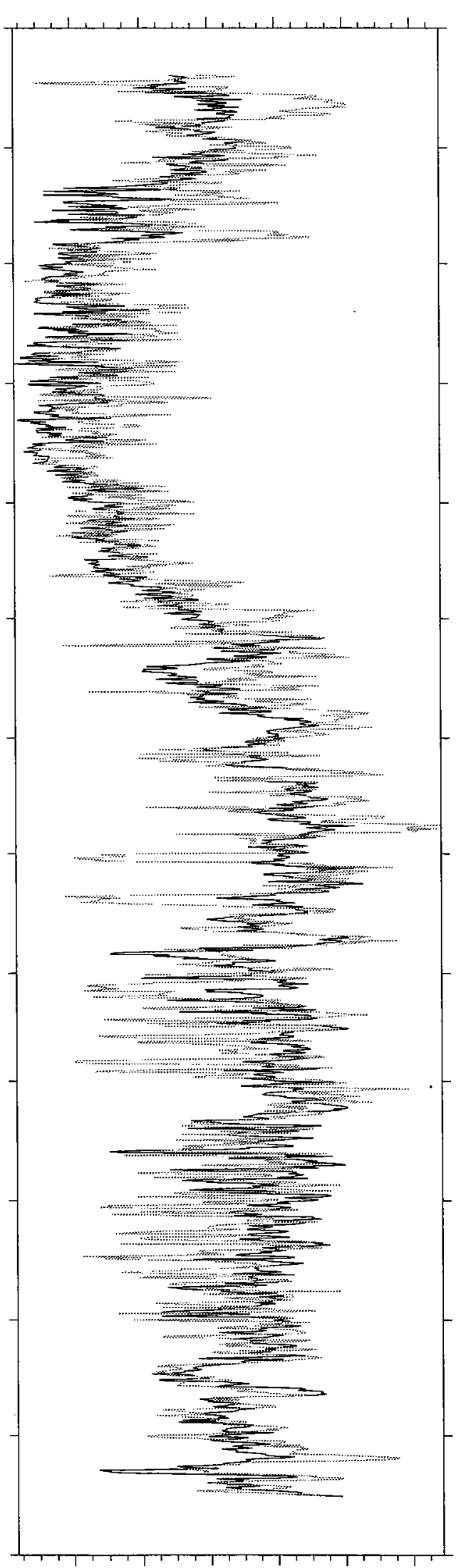

ก)

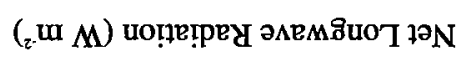

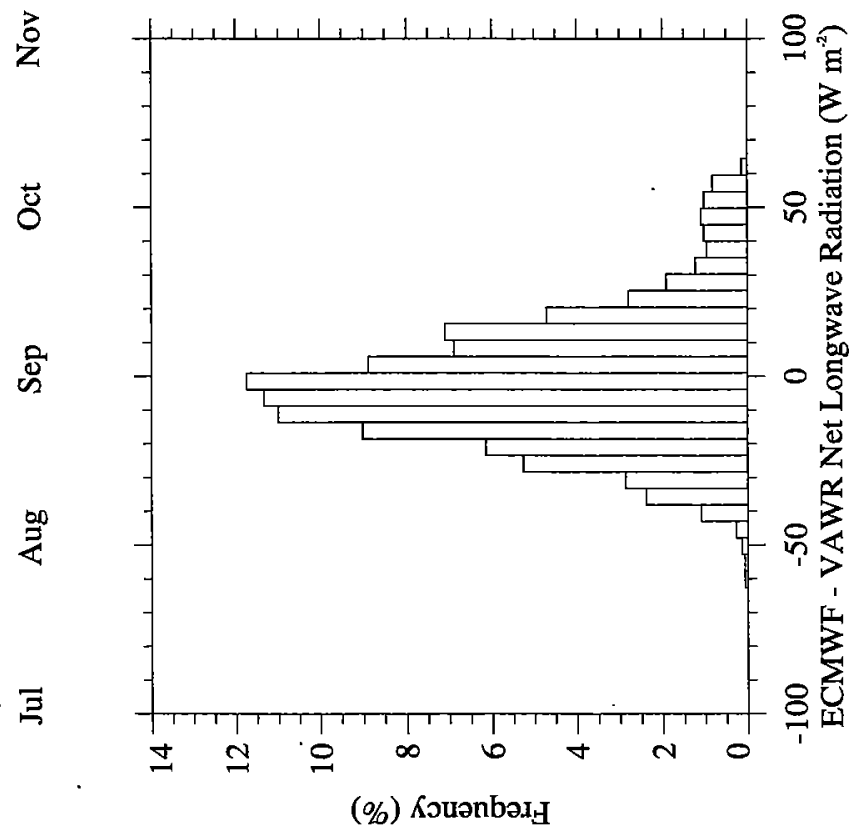

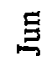

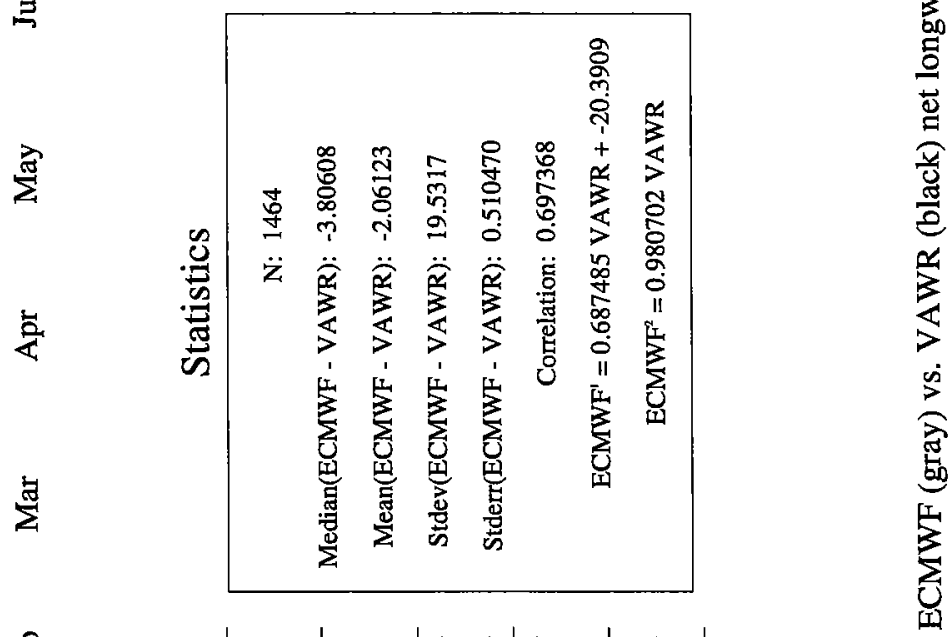

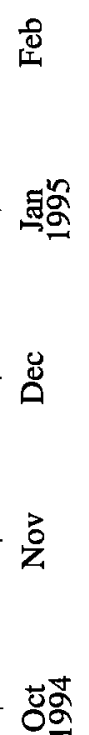

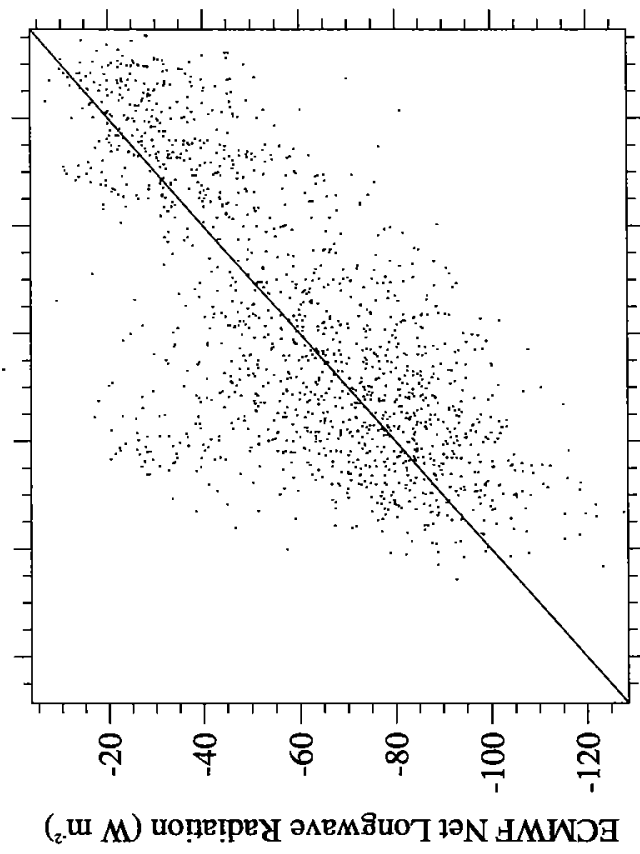

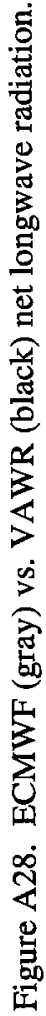



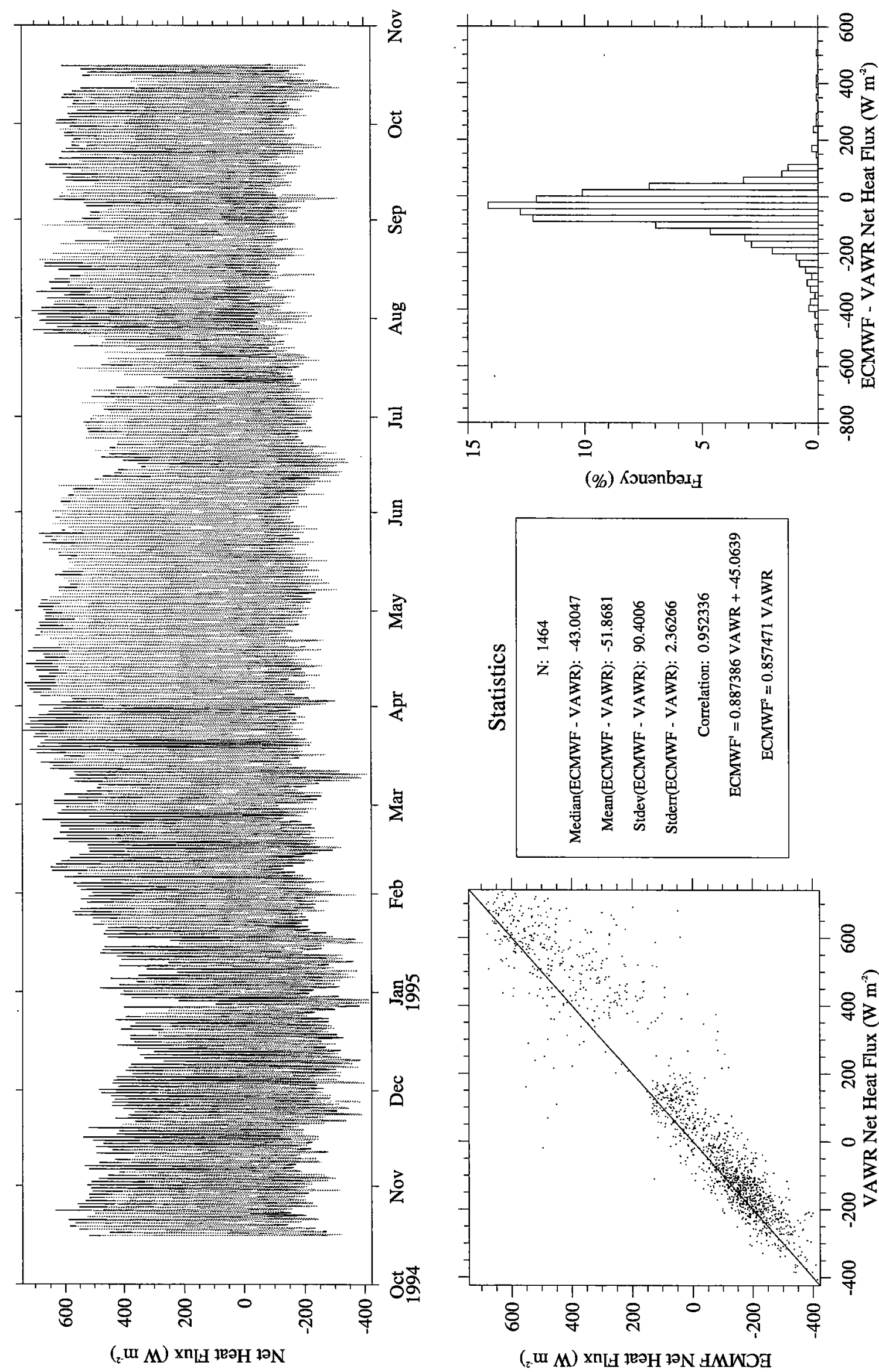

(\%) KouənbaI

豆

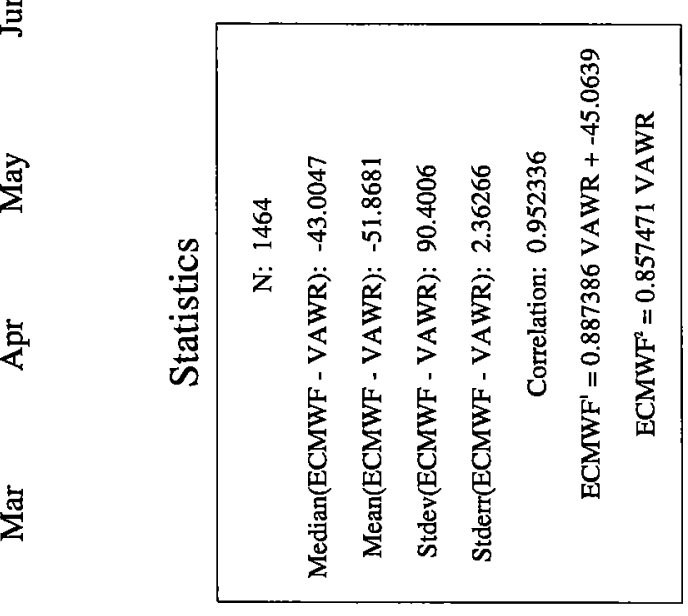



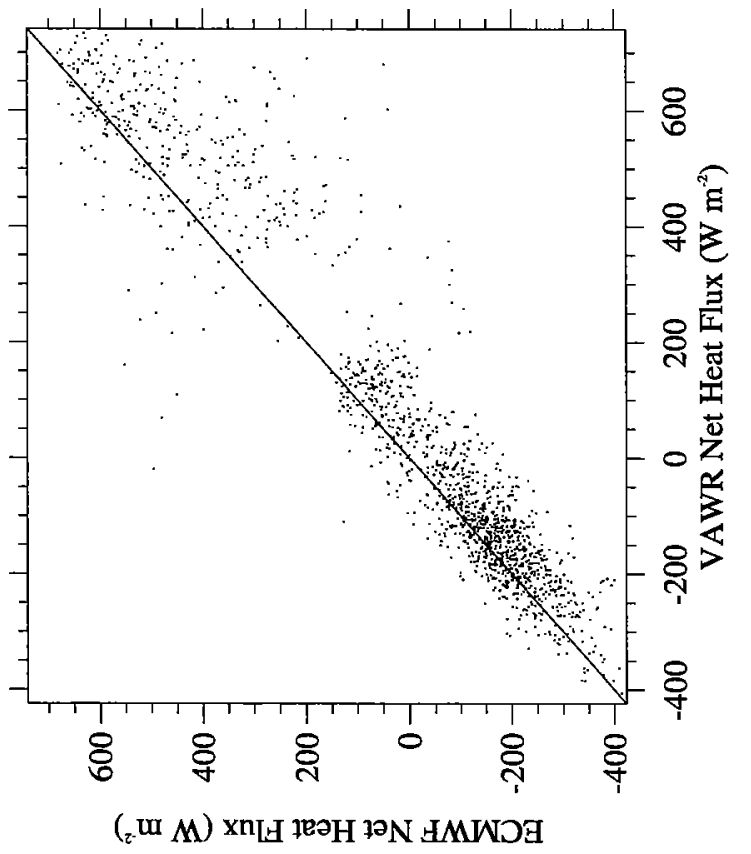



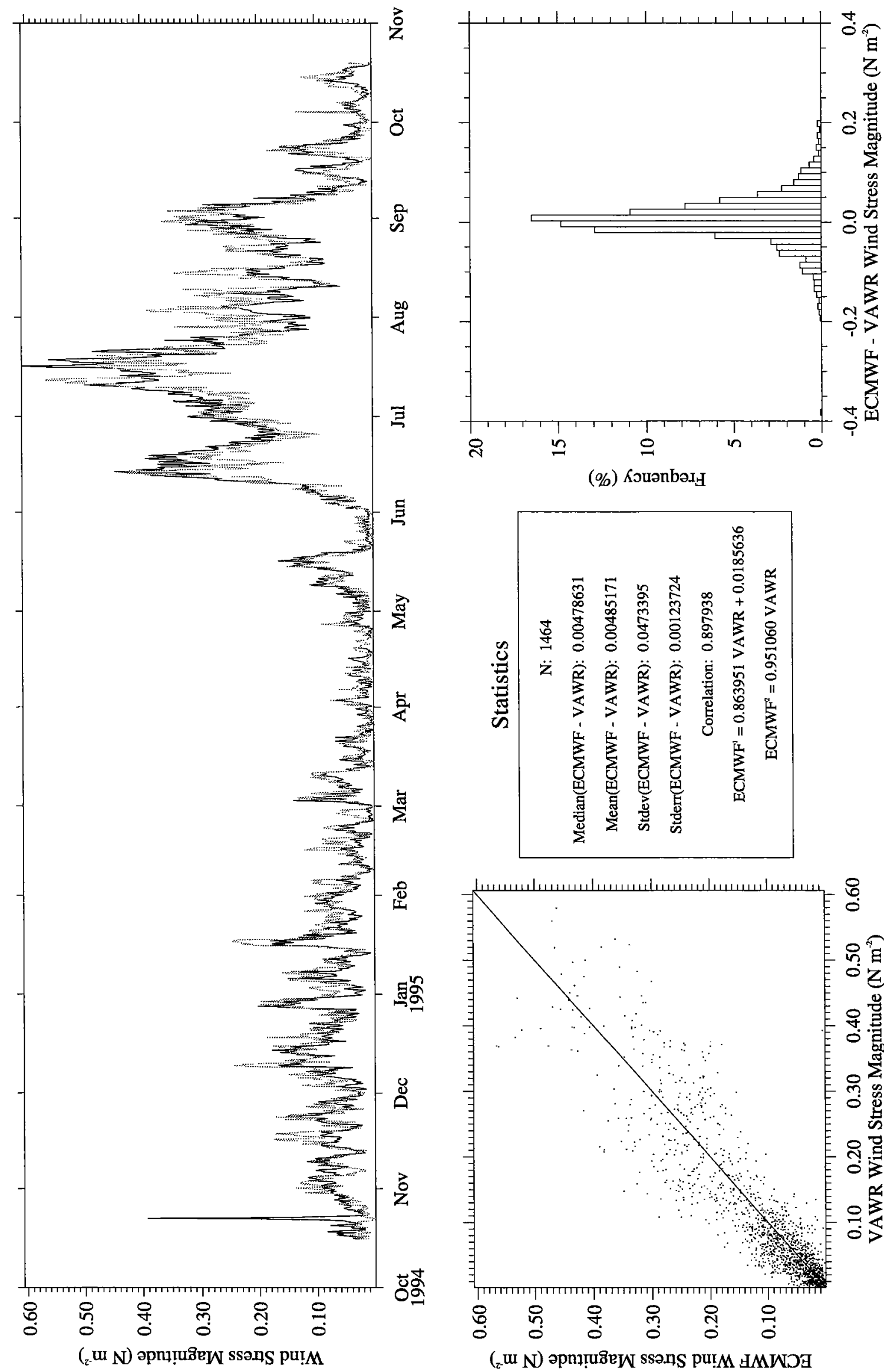

(\%) Кэuənbəx
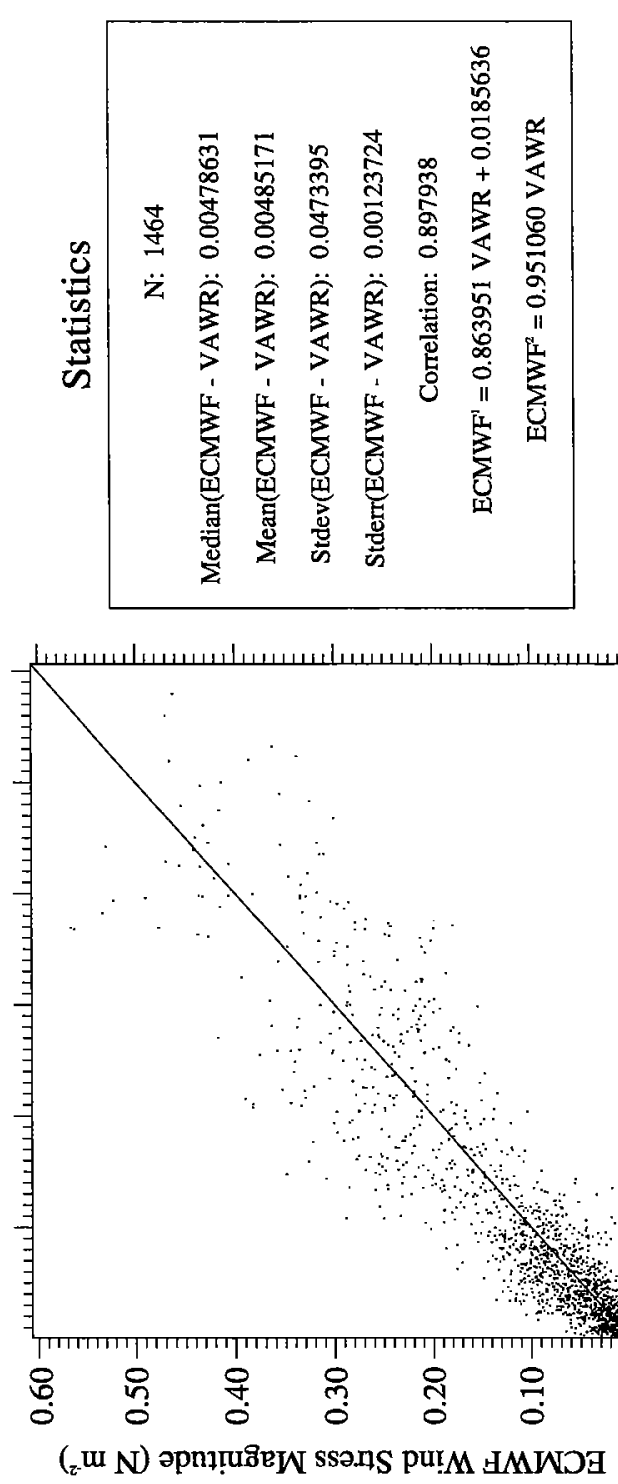

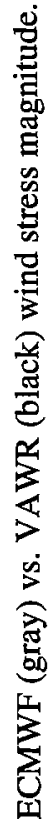

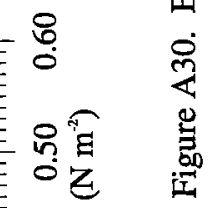



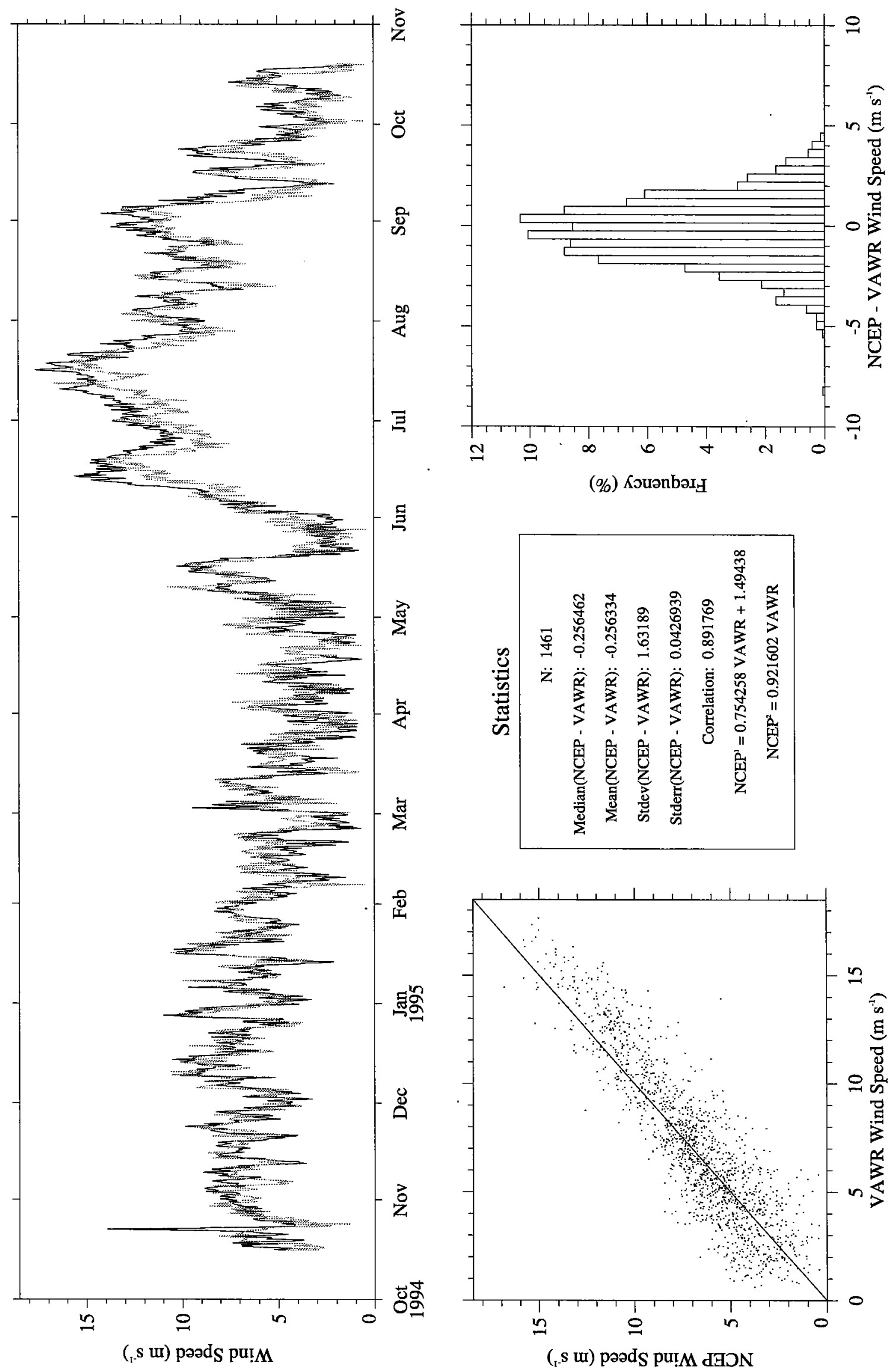

(\%) Kouənbəx

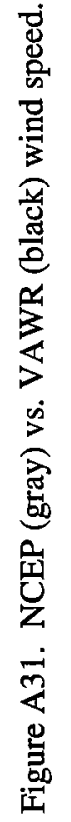

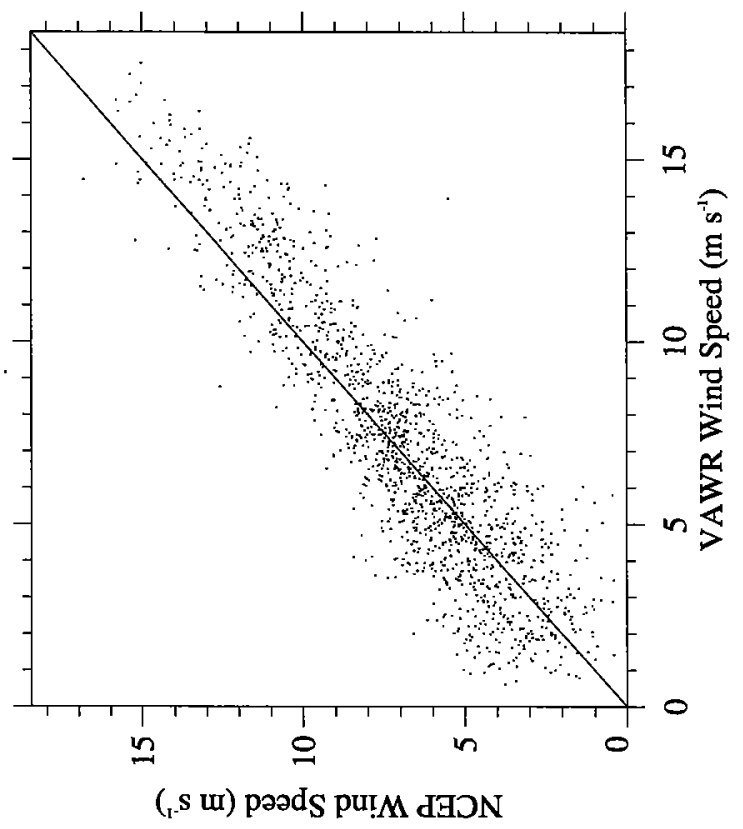




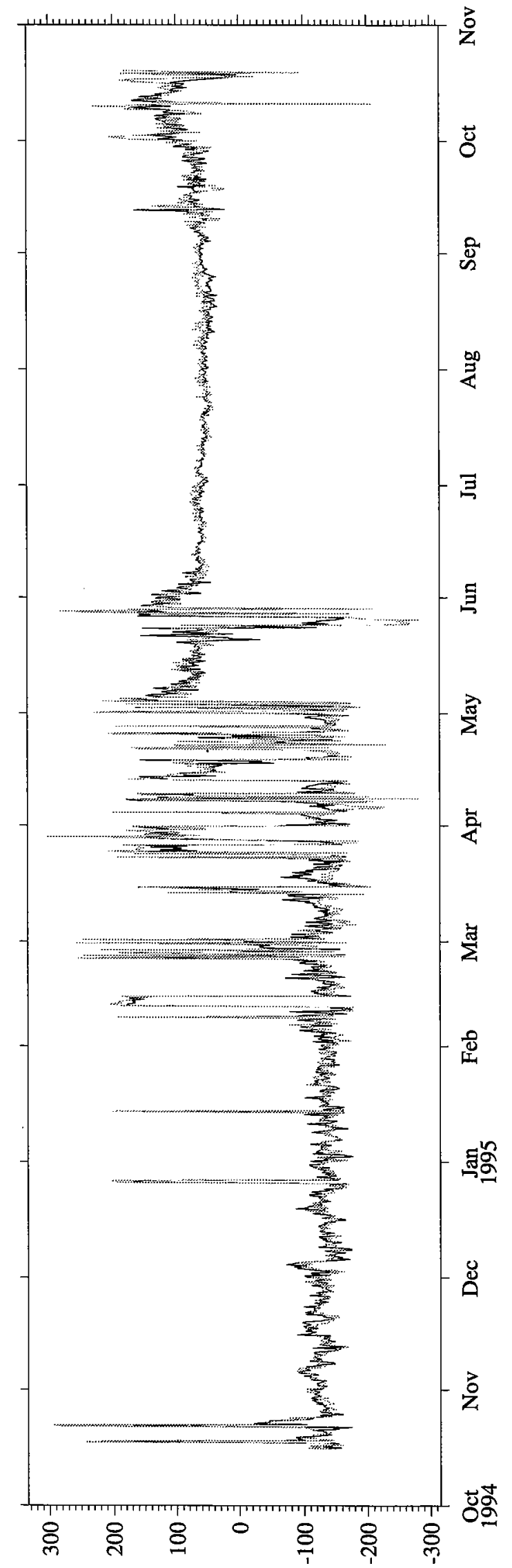

(。) uoṃวəп! рu!M

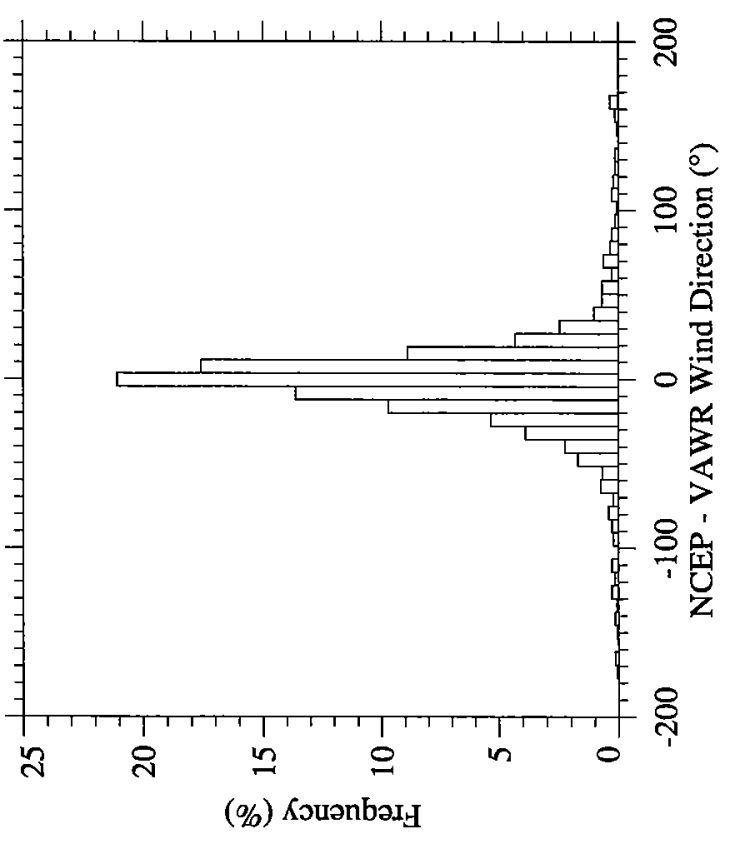

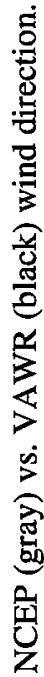

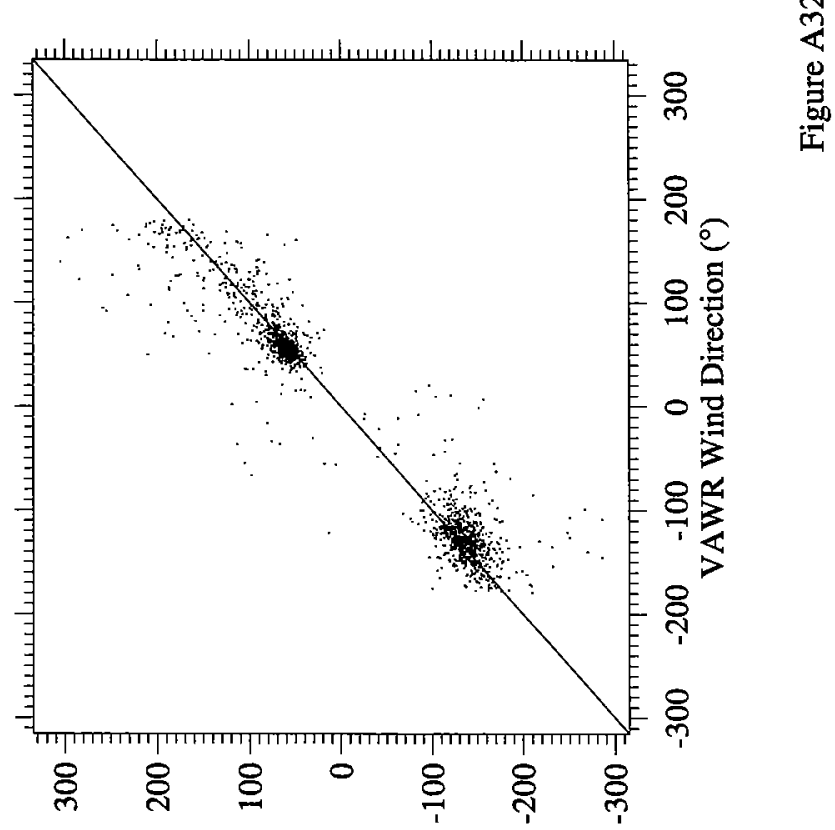

(॰) uo!̣oanc pu!M daכN 


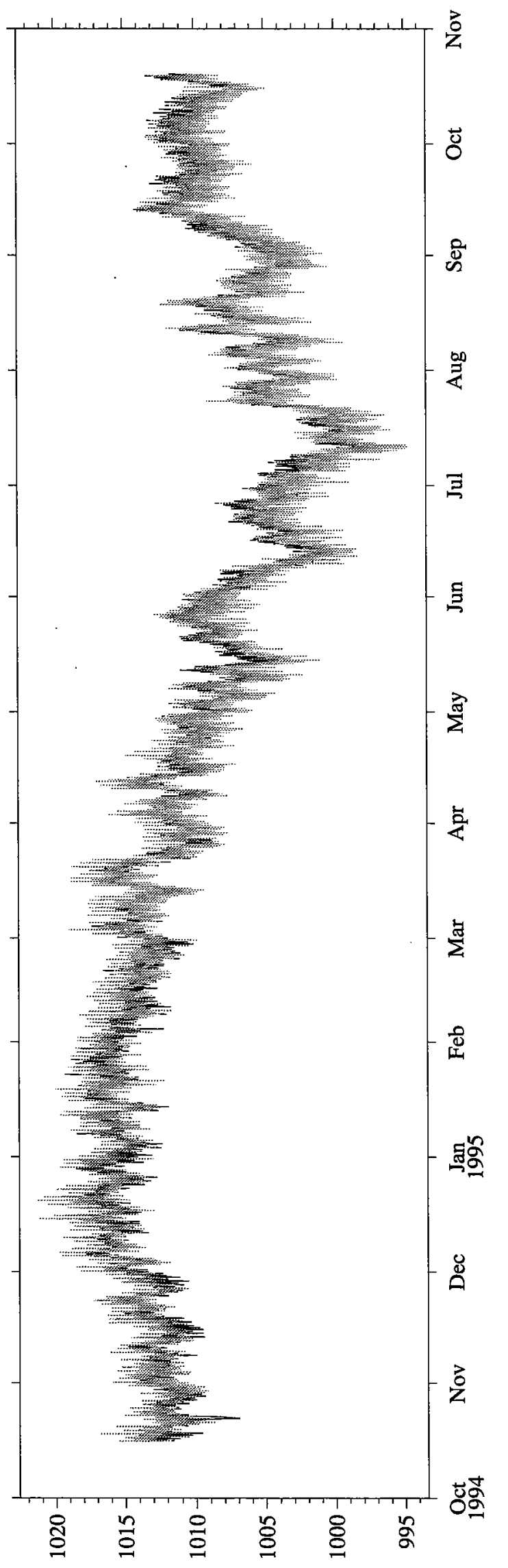

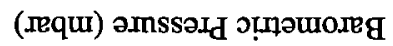

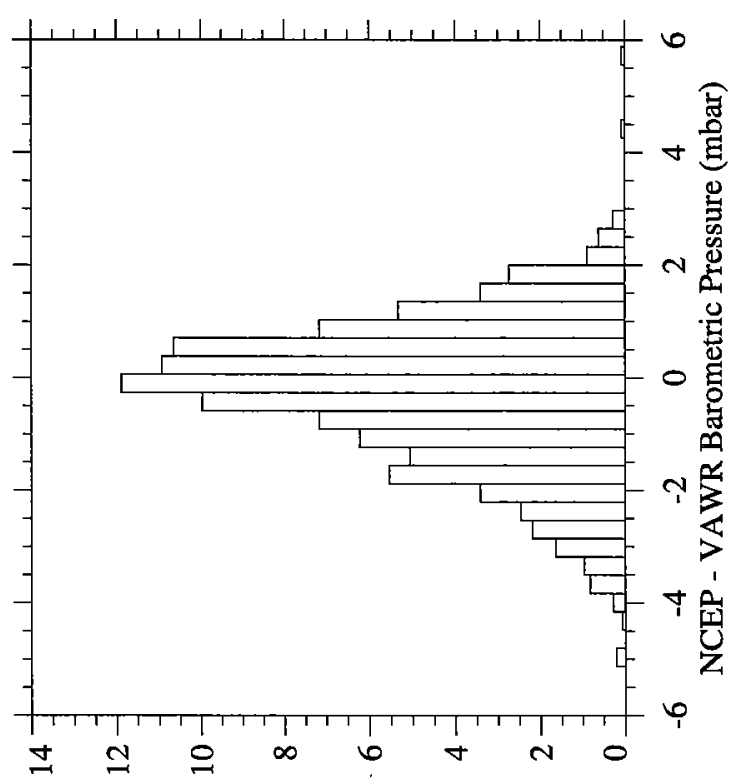

(\%) КouənbəI

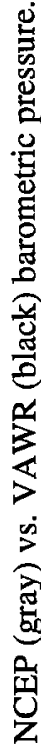

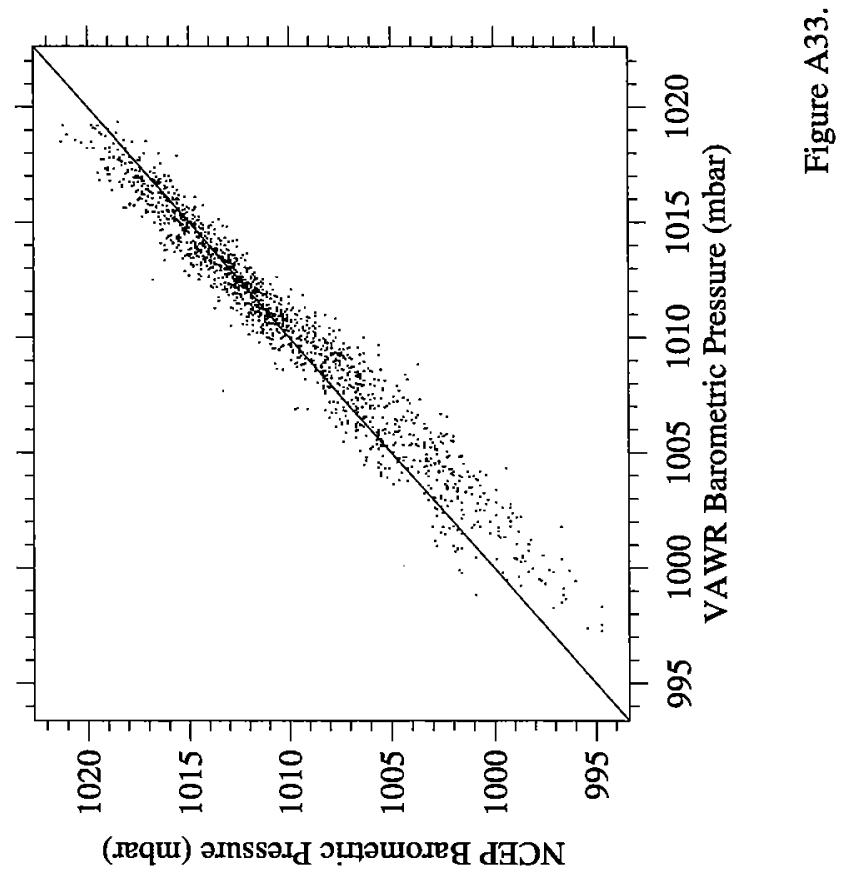



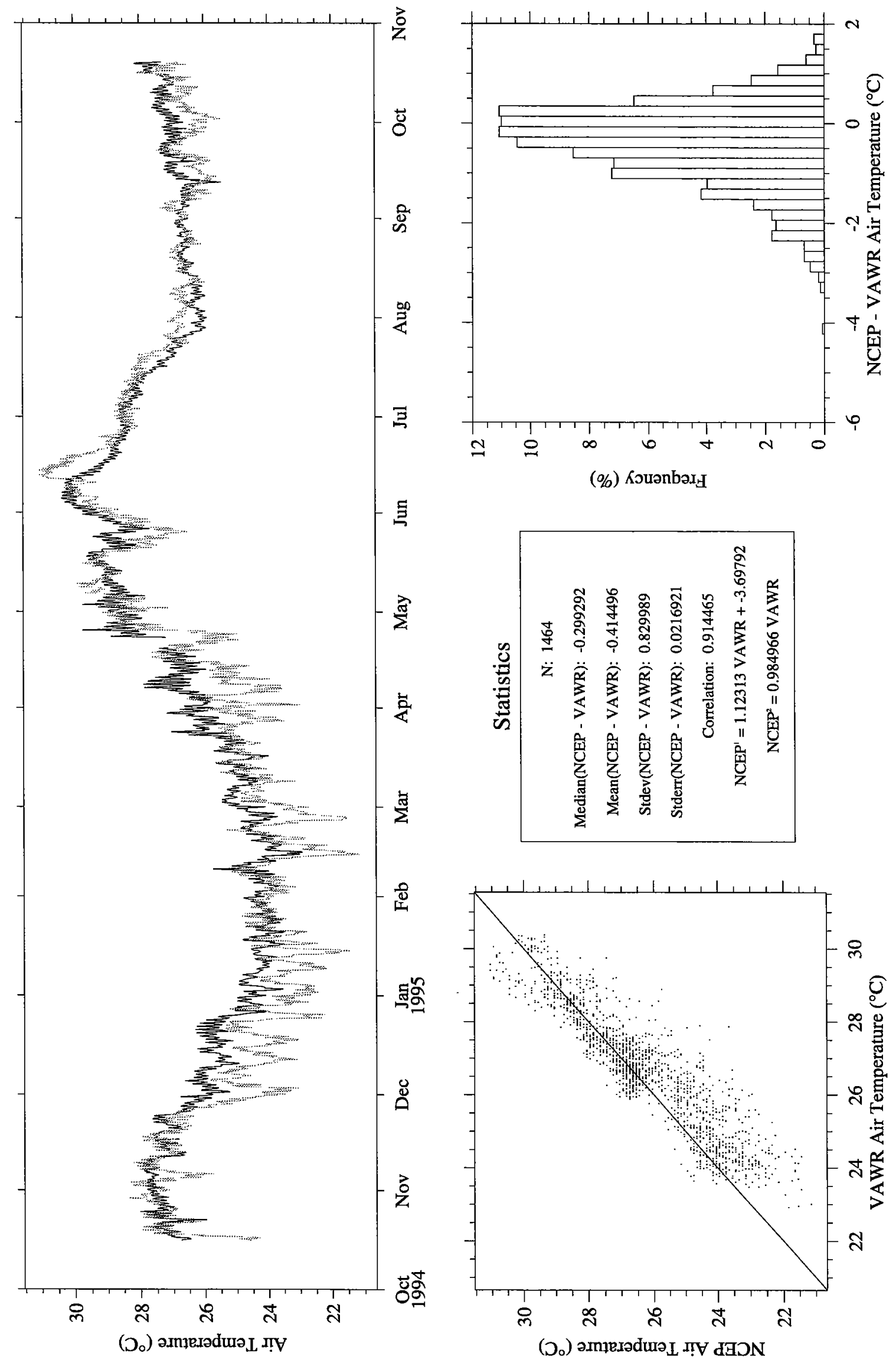

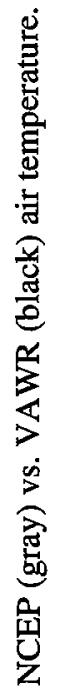

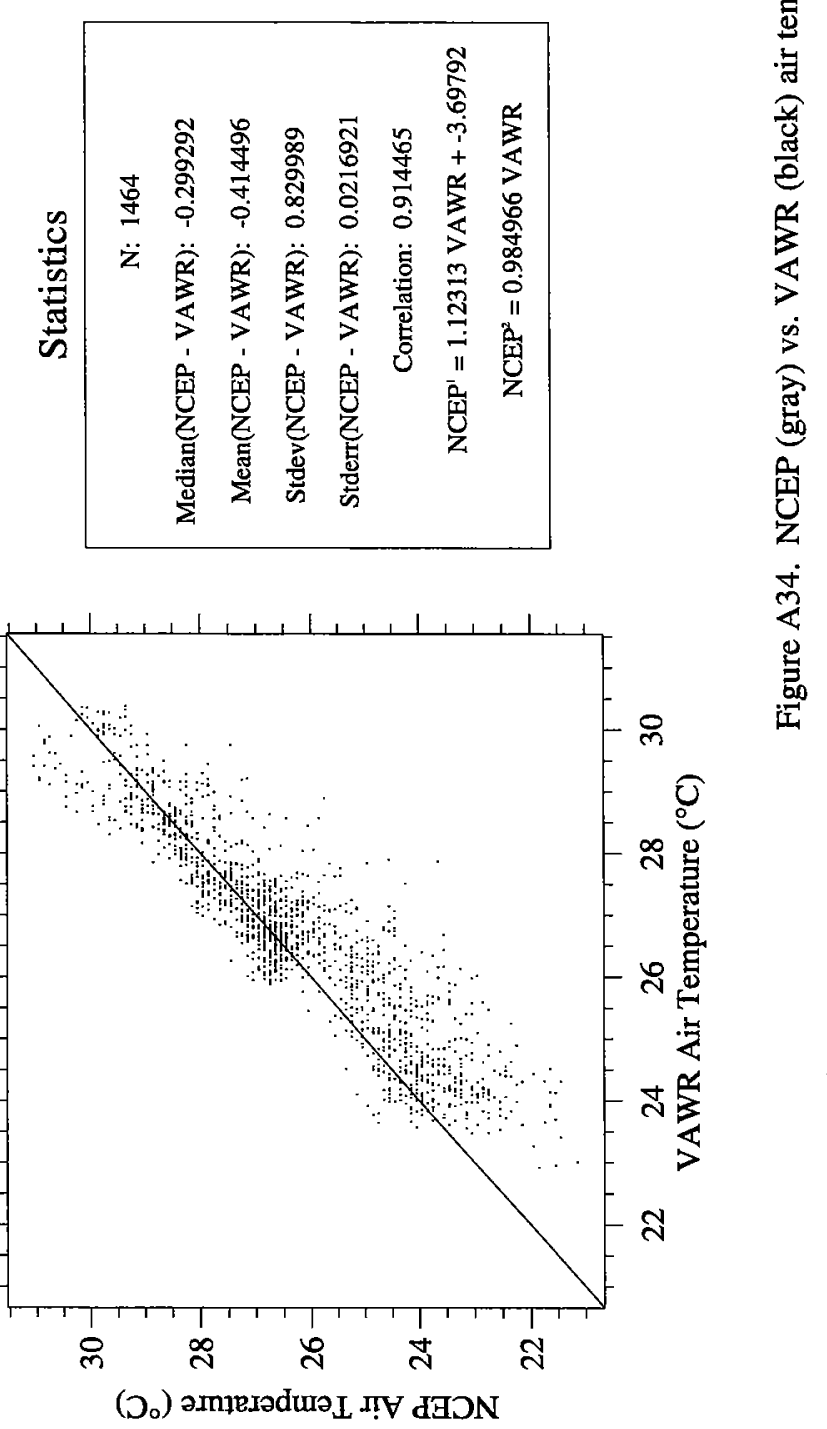




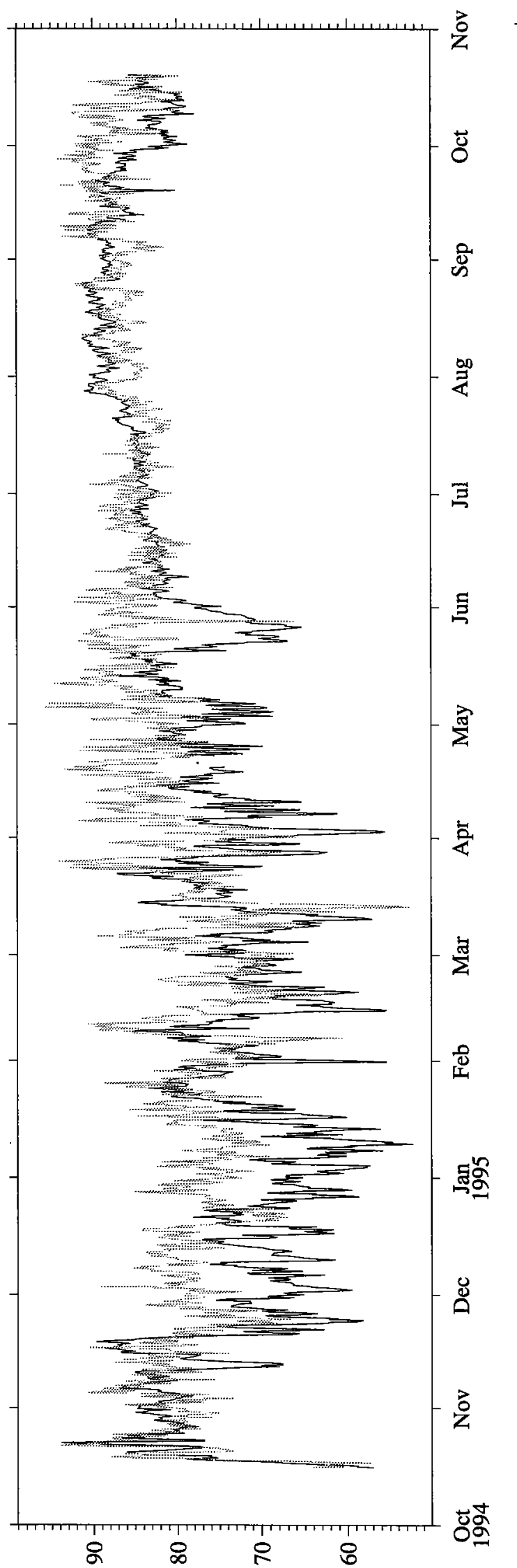

(\%) Кำp!

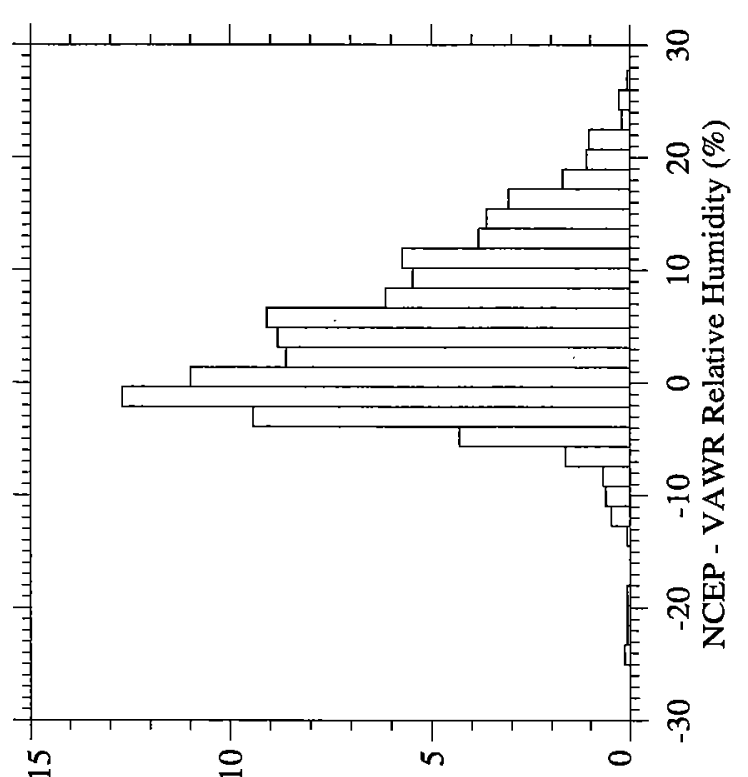

(\%) Kouənbəx

章

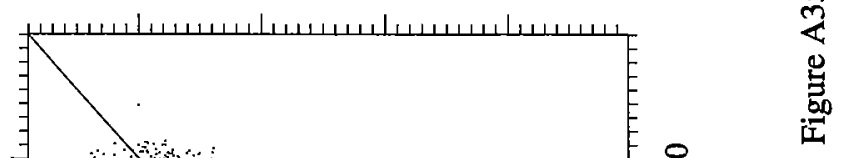

8

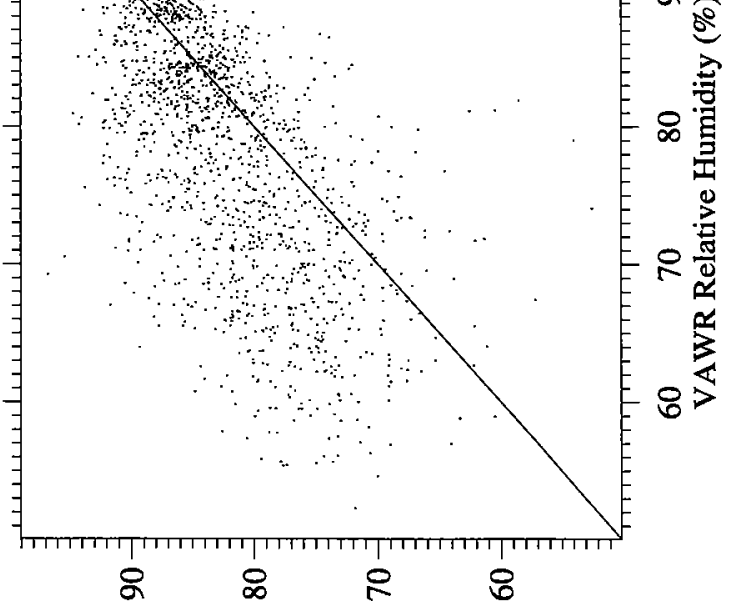

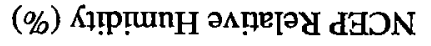




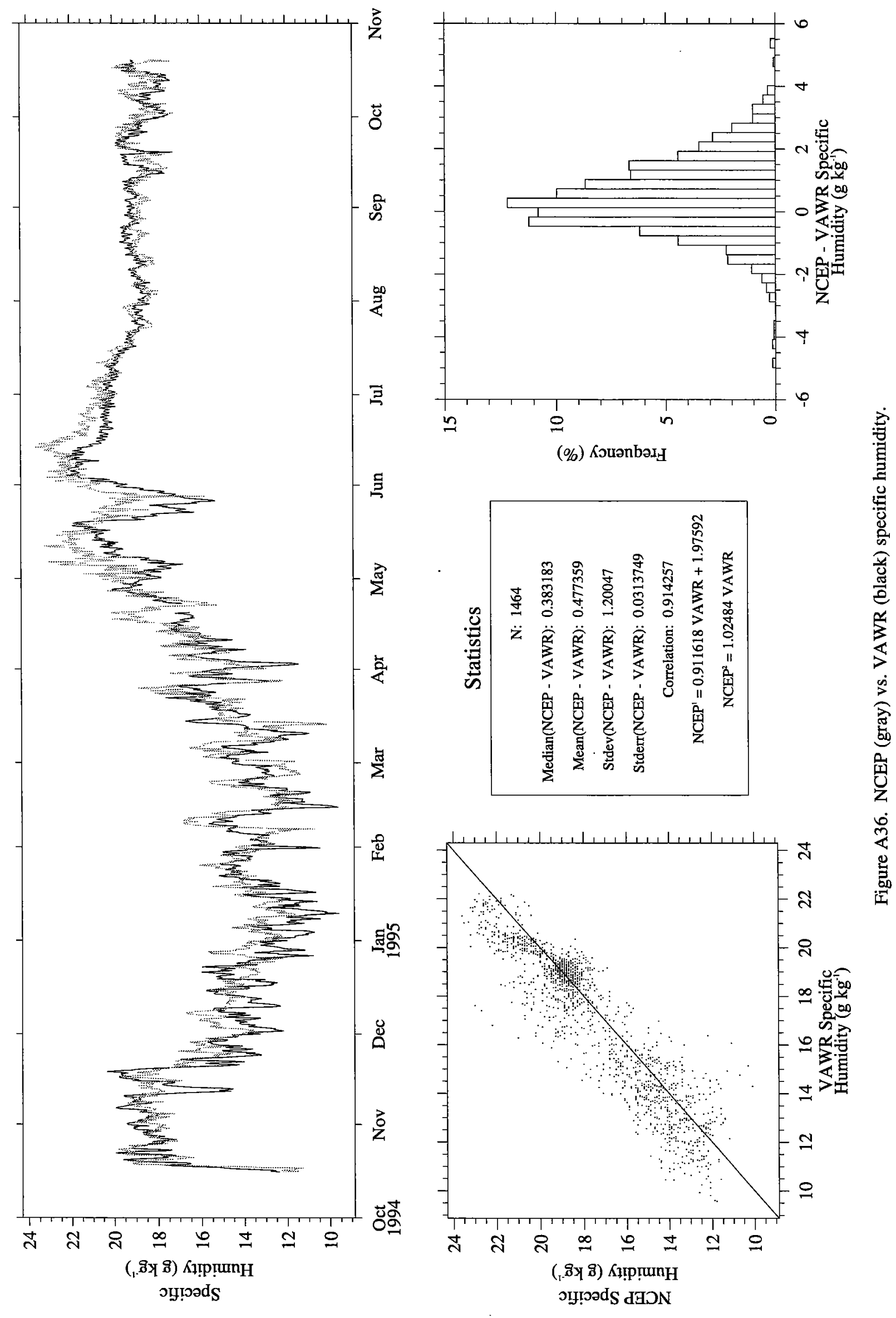



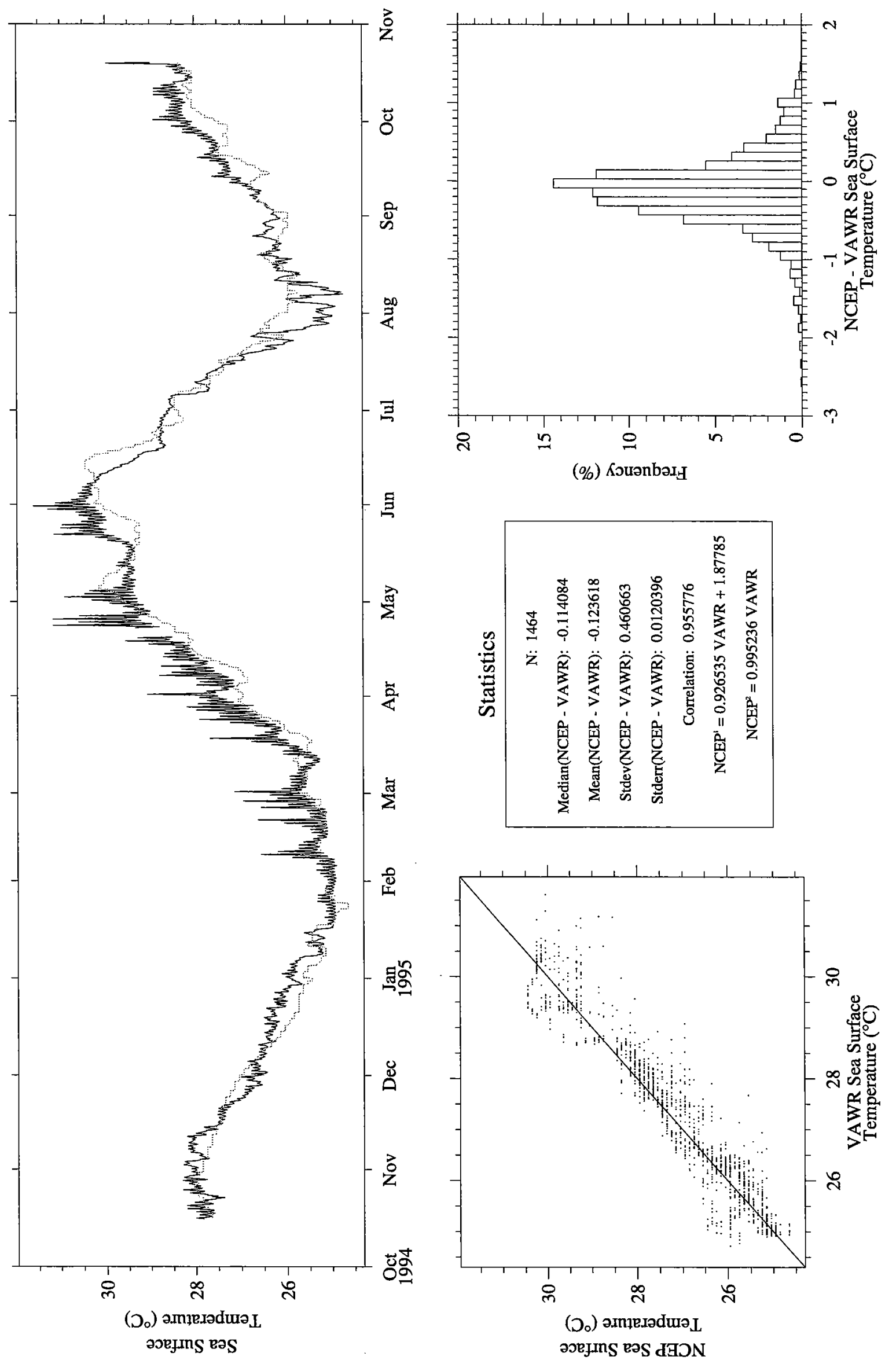

总 

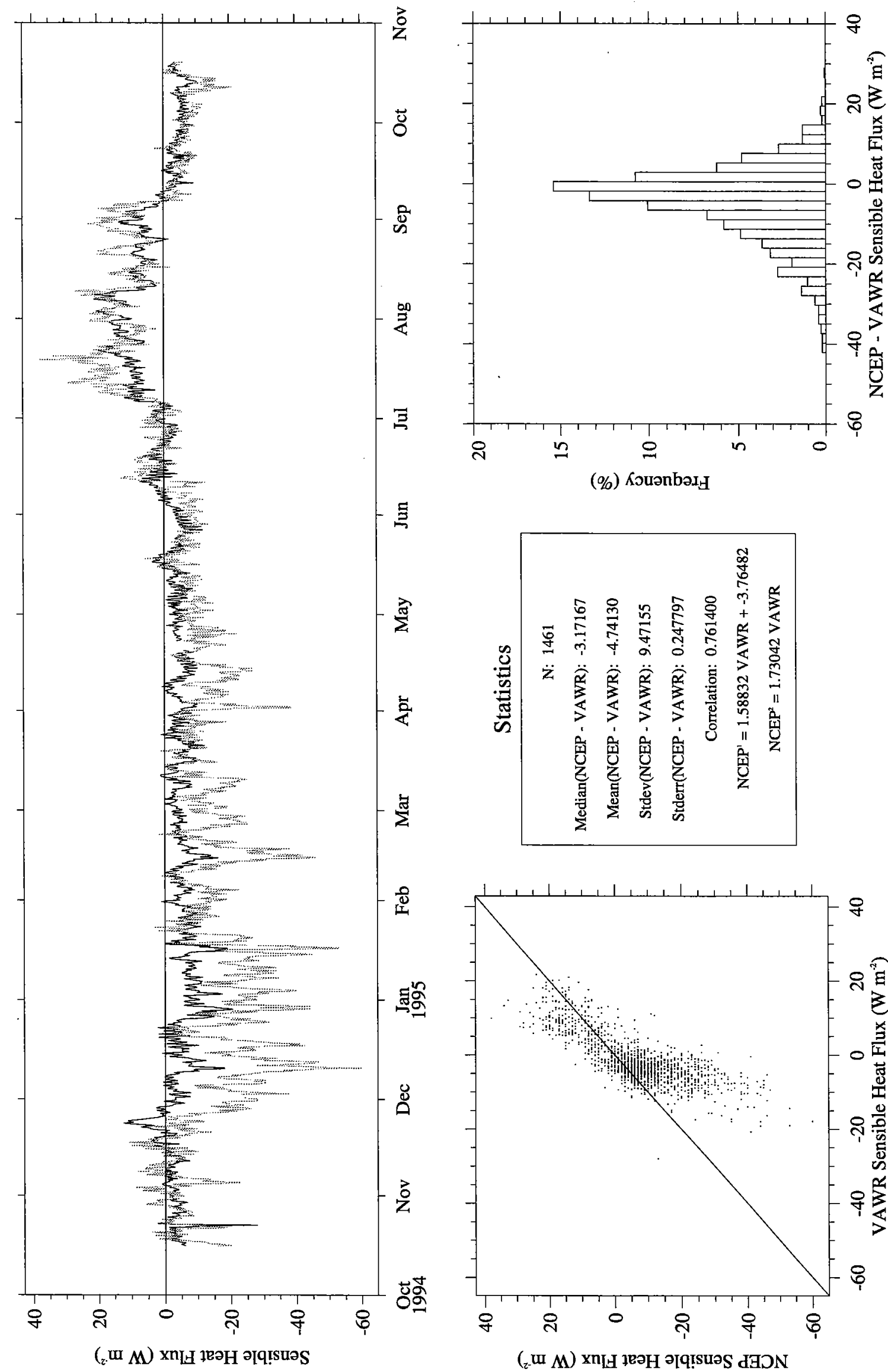

(\%) KouənbəدH

豆
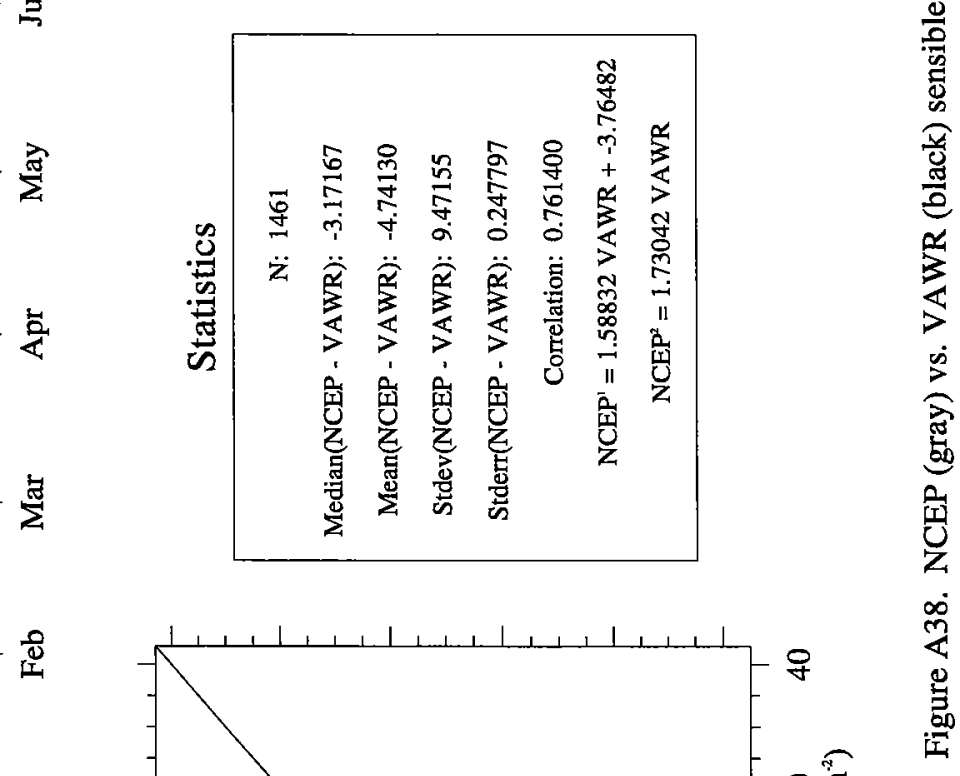

- ్ㅗ음

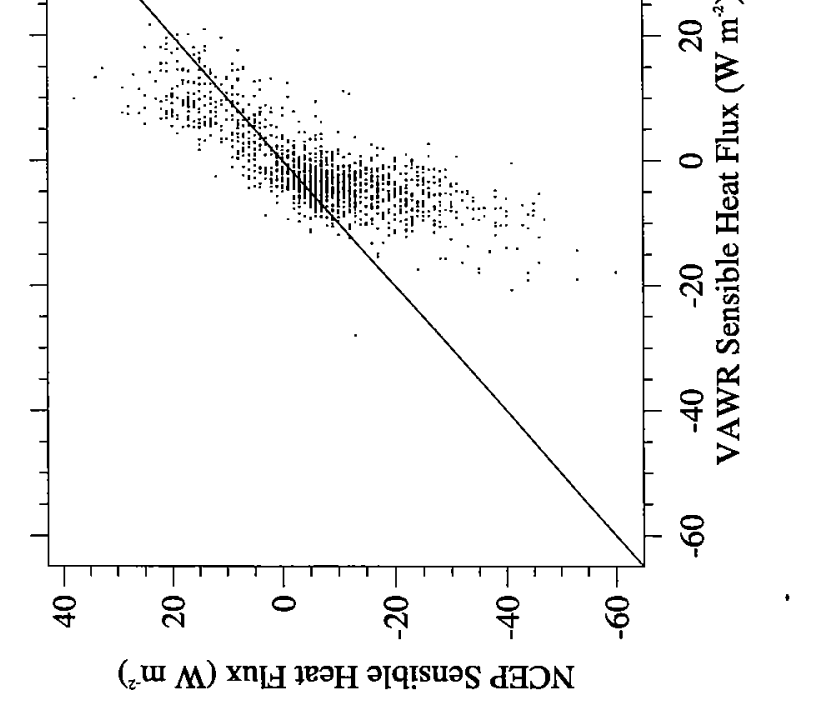



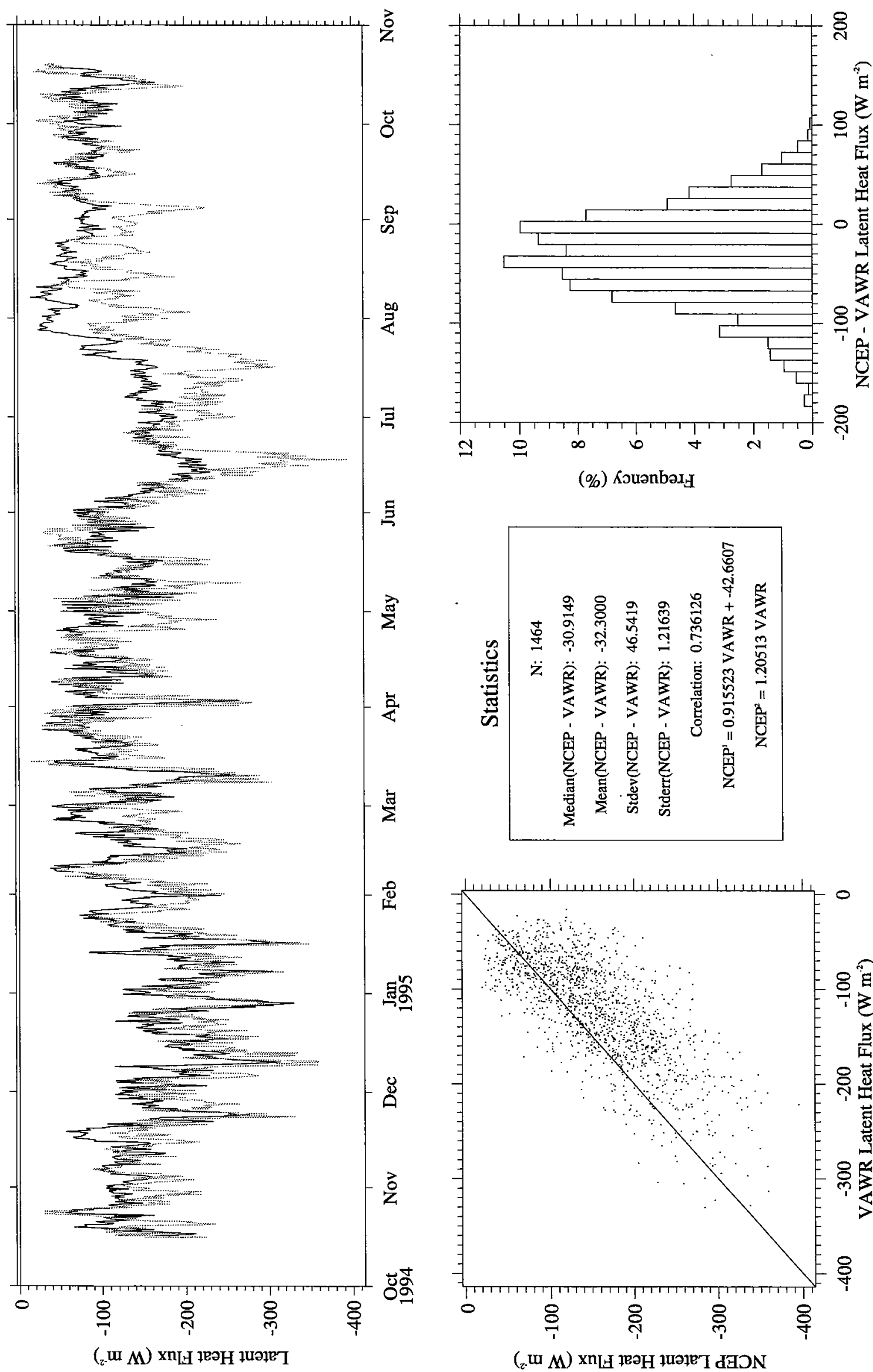

(\%) Kouənbax

吾

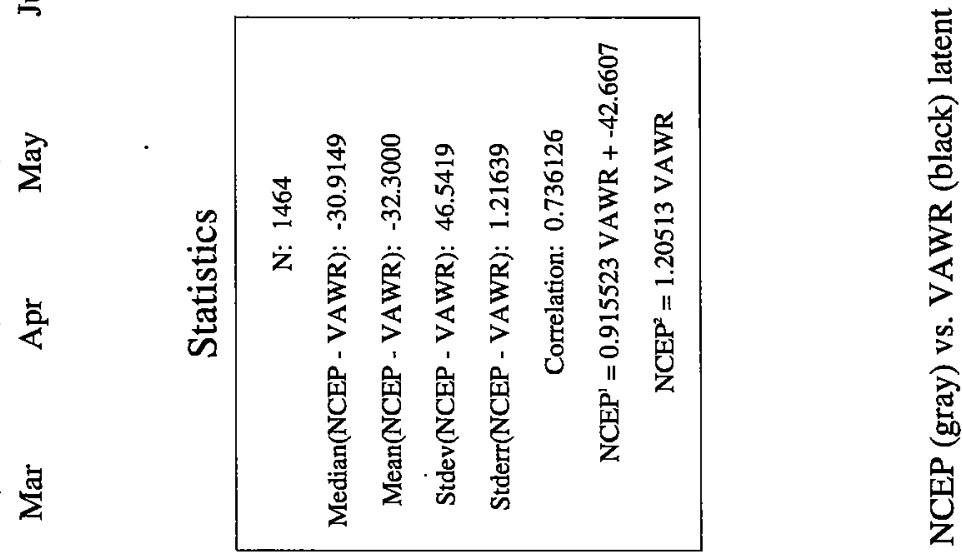

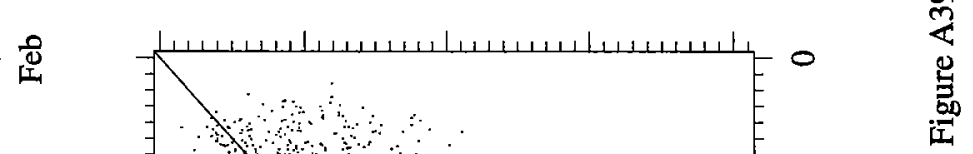

రัँ్す

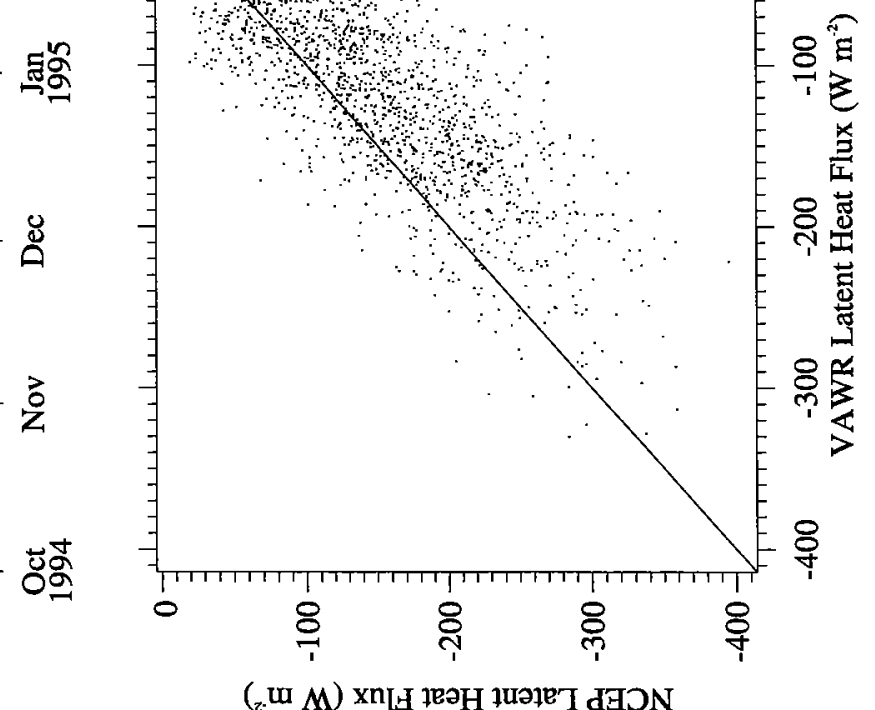

( (. $_{M} M$ ) xn 

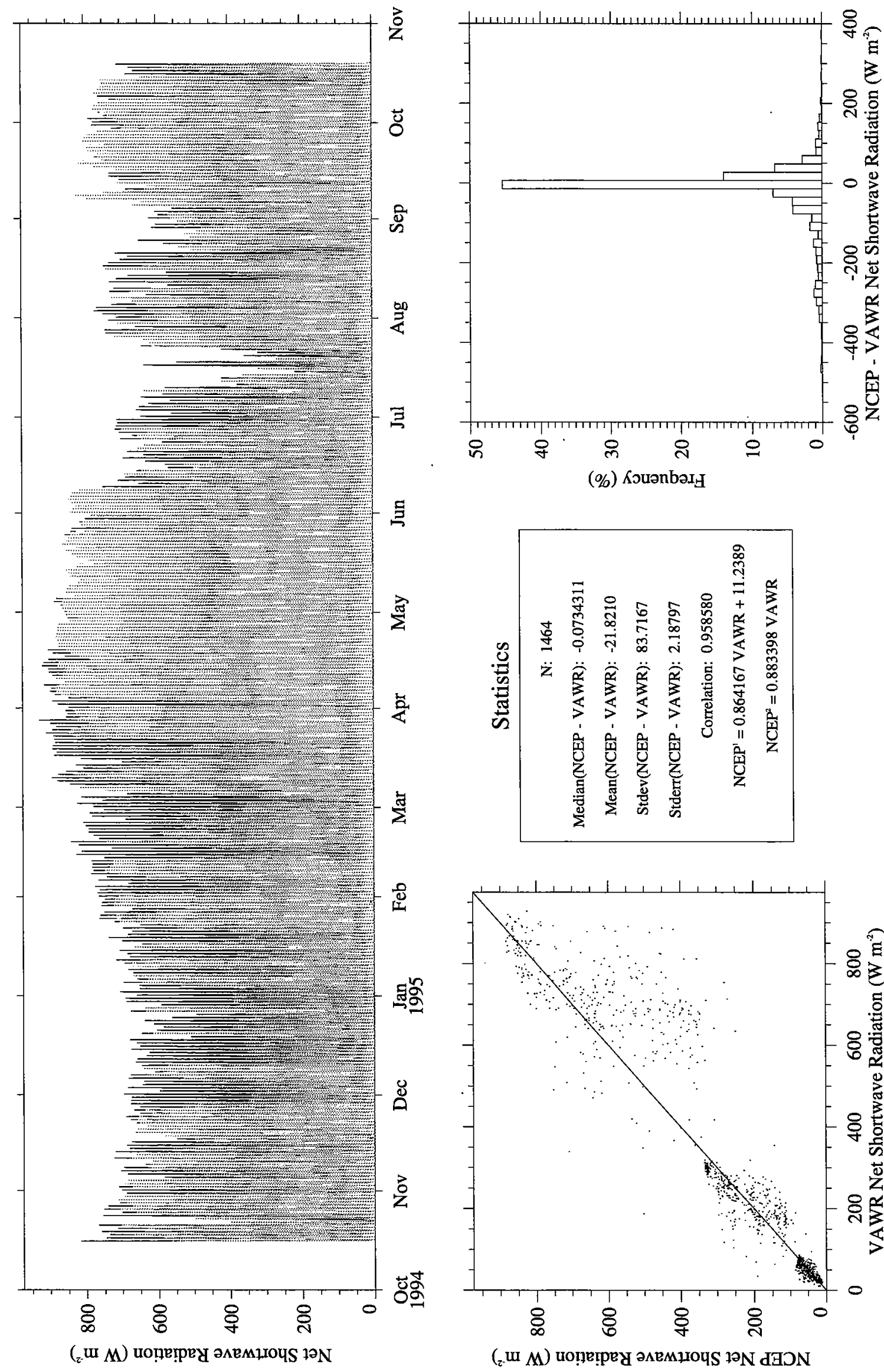

泀

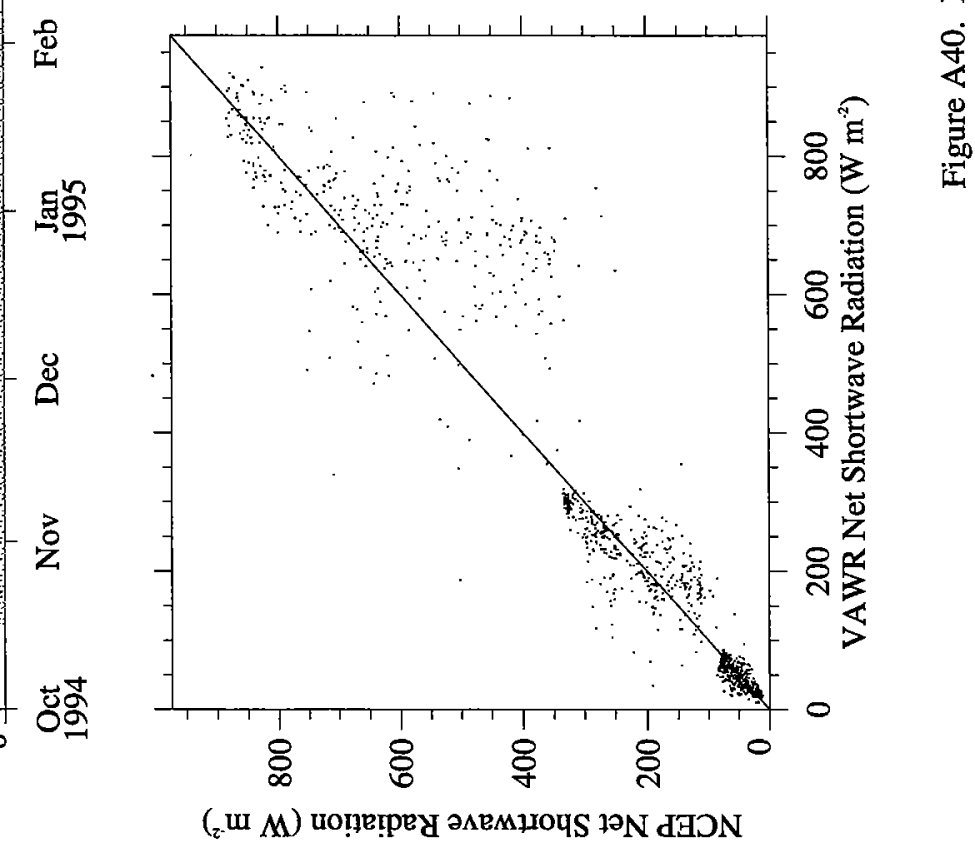



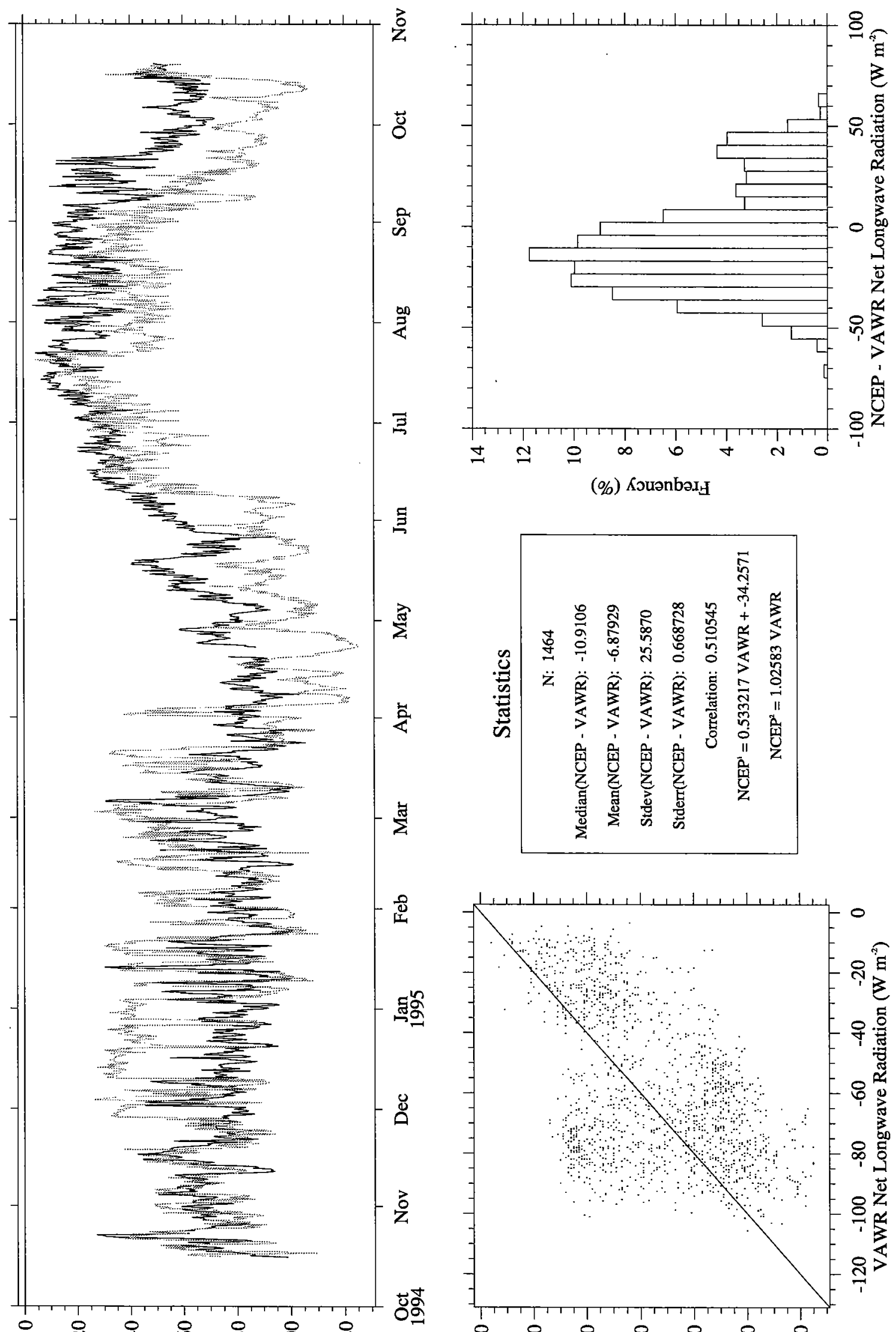

(\%) Кวuənbə⿱一𫝀甘

号

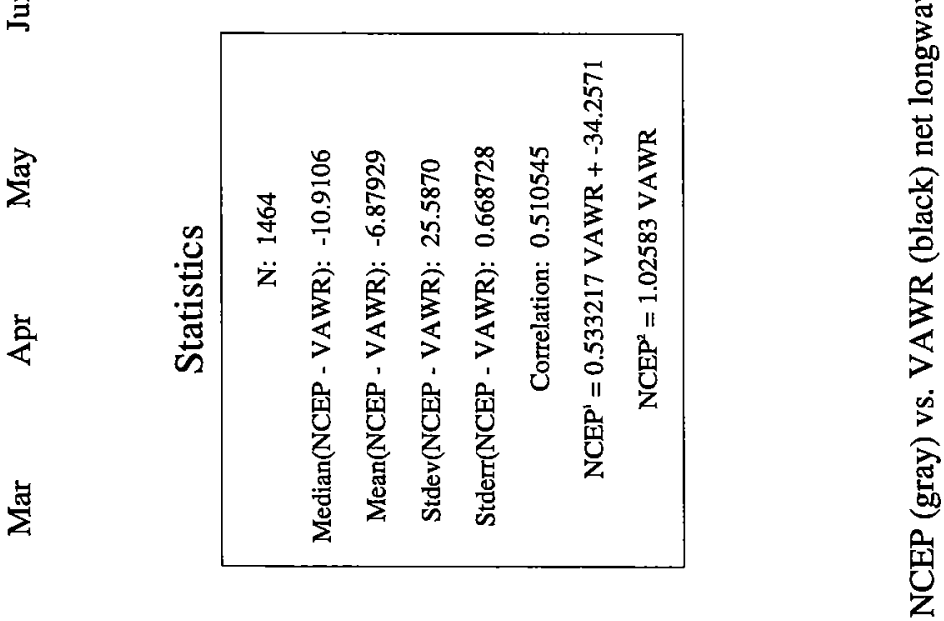

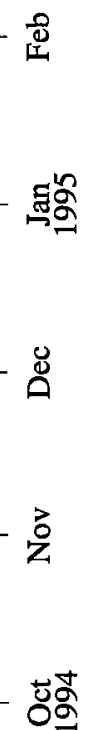

ง

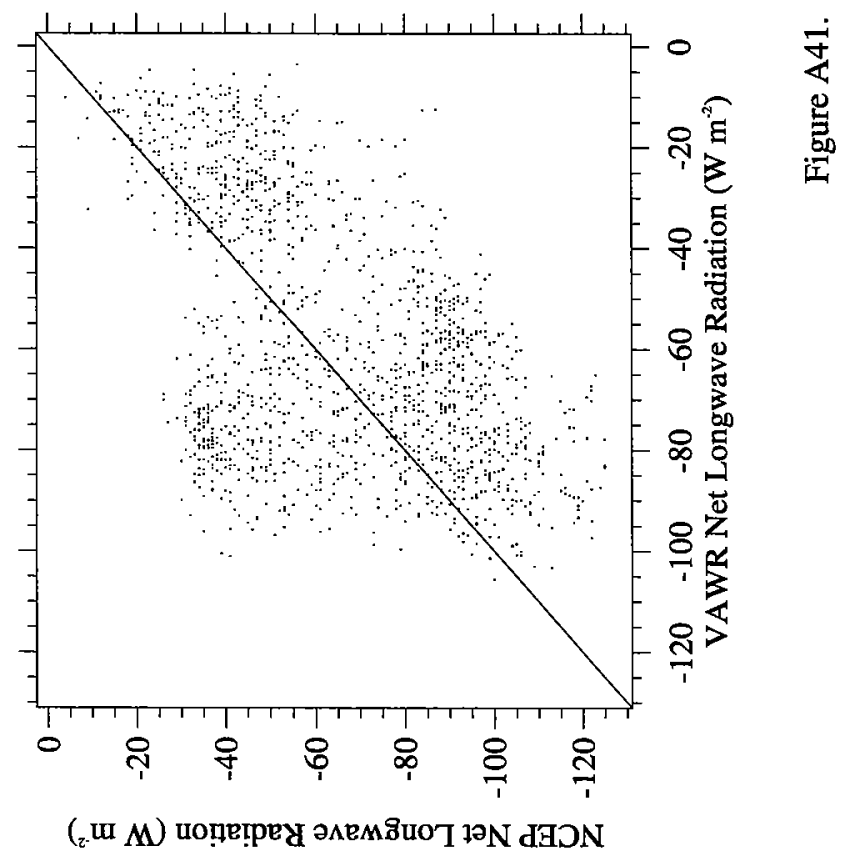



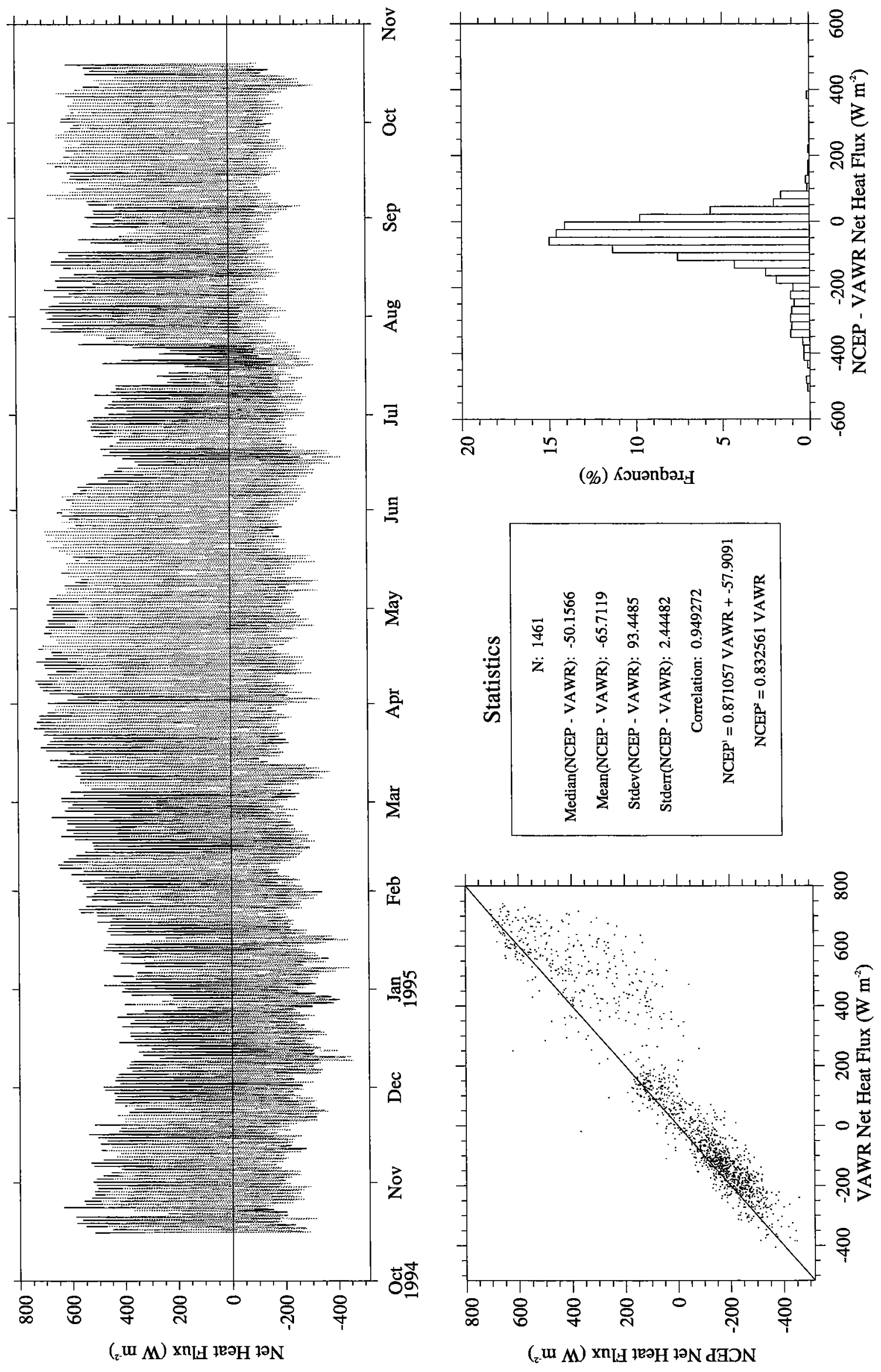

告

(\%) Kouənbəג

总

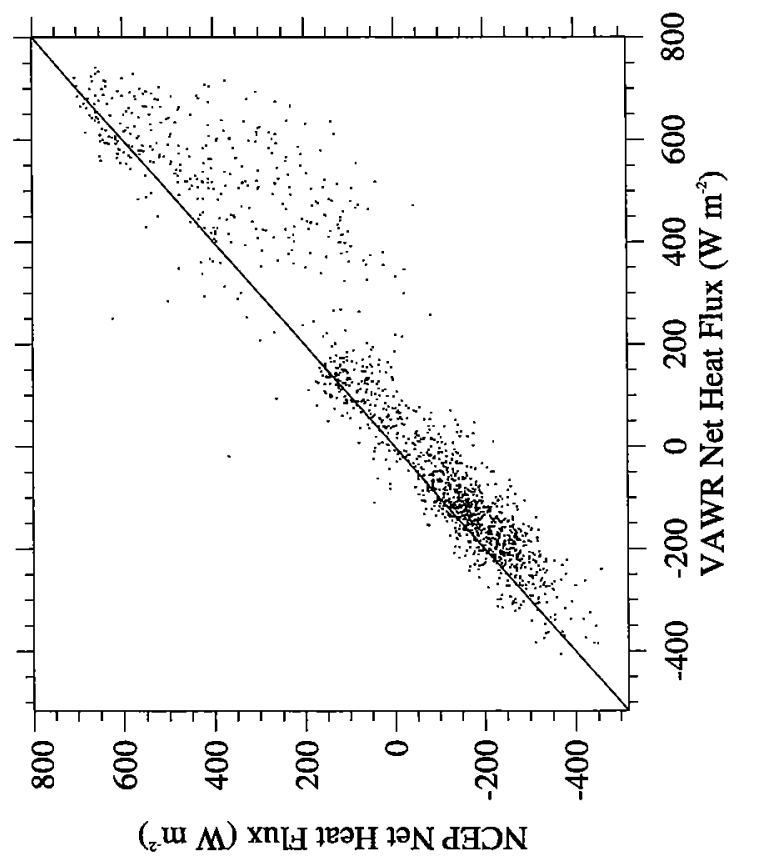



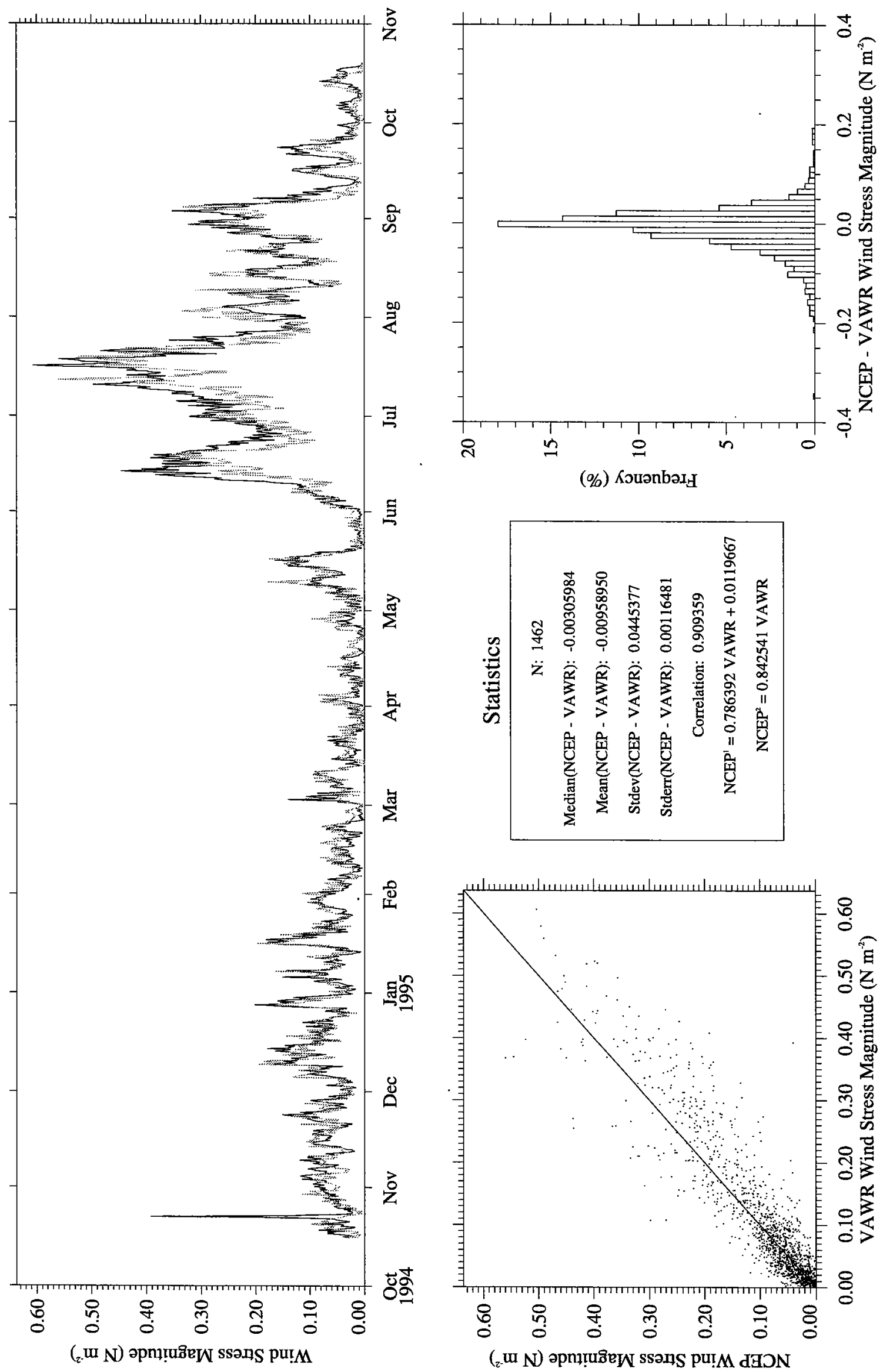

(\%) Kouənbər

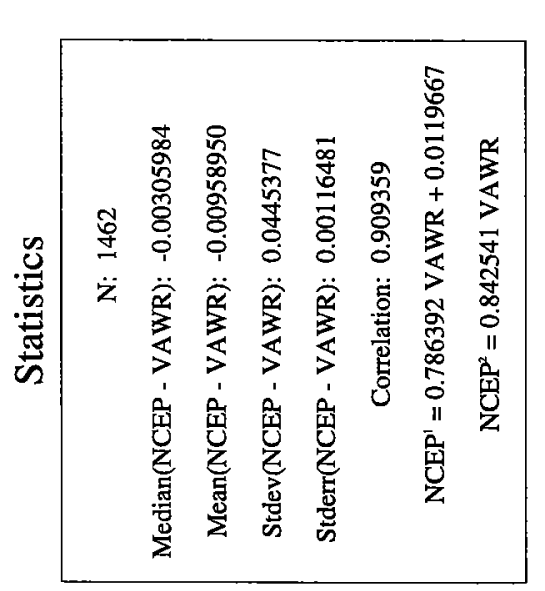

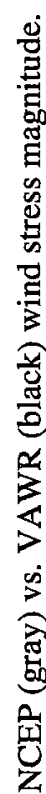

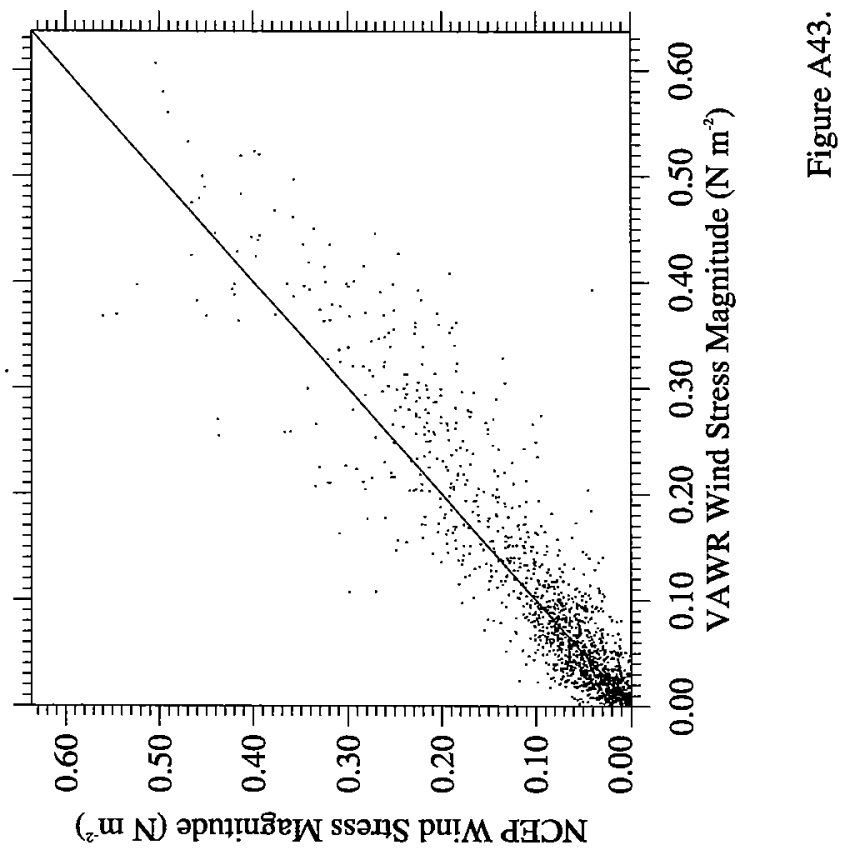




\section{Appendix B: Instrument Serial Numbers}

Table B1. Serial numbers of meteorological instrumentation on the WHOI buoy.

\begin{tabular}{lcc}
\hline & & \\
Parameter & Arab 1 & Arab 2 \\
\hline$V A W R$ & V721WR & V720WR \\
\hline Air temperature & Thermistor 5804 & Thermistor 5854 \\
Relative humidity & V-034-001 & V-029 \\
Barometric pressure & 46398 & 44147 \\
Wind speed & V721WR & V720WR \\
Wind direction & V721WR & V720WR \\
Short-wave radiation & 25418 & 21972 \\
Long-wave radiation & 28463 & 28459 \\
Sea temperature & Thermistor 5005 & Thermistor 5568 \\
& & \\
IMET & Logger 226 & Logger 228 \\
Air temperature & TMP 101 & TMP 105 \\
Relative humidity & HRH 111 & HRH 108 \\
Barometric pressure & BPR 107 & BPR 106 \\
Wind speed & WND 104 & WND 111 \\
Wind direction & WND 104 & WND 111 \\
Short-wave radiation & SWR 109 & SWR 104 \\
Long-wave radiation & LWR 101 & LWR 103 \\
Sea temperature & SST 106 & SST 006 \\
Aspirated air temperature & TMP 108 & TMP 106 \\
Precipitation & PRC 101 & PRC 108 \\
& & \\
Stand-alone & & \\
Relative humidity with air temp. & 002 & 005 / 27439 \\
\hline
\end{tabular}

Table B2. Serial numbers of WHOI instrumentation deployed on UW moorings.

\begin{tabular}{cccc} 
Depth $(\mathrm{m})$ & Sensor & Arab 1 & Arab 2 \\
\hline $\begin{array}{c}\text { UW South } \\
20\end{array}$ & Brancker & T-3265 & T-3835 \\
250 & Brancker & T-2537 & T-2533 \\
300 & VMCM & VM-016 & VM-016 \\
500 & VMCM & VM-018 & VM-018 \\
750 & VMCM & VM-021 & VM-021 \\
1500 & VMCM & VM-025 & VM-025 \\
3025 & VMCM & VM-038 & VM-038 \\
& & & \\
UW North & & & \\
20 & Brancker & T-3279 & T-3279 \\
250 & Brancker & T-2541 & T-2541 \\
\hline
\end{tabular}


Table B3. Serial numbers of subsurface instrumentation on the WHOI buoy.

\begin{tabular}{|c|c|c|c|}
\hline Depth (m) & Sensor & Arab 1 & Arab 2 \\
\hline 0.17 & Brancker & T-3836 & T-3291 \\
\hline 0.43 & Brancker & $\mathrm{T}-3662$ & T-3299 \\
\hline 0.92 & Brancker & T-4483 & T-3280 \\
\hline 1.37 & Brancker & T-5432 & None deployed \\
\hline 1.41 & Brancker & $\mathrm{T}-3667$ & $\mathrm{~T}-3263$ \\
\hline 1.42 & Seacat & 1179 & 928 \\
\hline 1.91 & Brancker & $\mathrm{T}-3839$ & $\mathrm{~T}-3274$ \\
\hline 2.42 & Brancker & T-3762 & T-3271 \\
\hline 3.5 & MTR & 3240 & 3250 \\
\hline 4.5 & Brancker & T-3763 & $\mathbf{T}-3341$ \\
\hline 5 & VMCM & VM-011 & VM-050 \\
\hline 10 & MVMS & 302703-LD & 203805-LD \\
\hline 15 & VMCM & VM-037 & VM-030 \\
\hline 20 & Brancker & $\mathrm{T}-3259$ & $\mathrm{~T}-4488$ \\
\hline 25 & VMCM & VM-039 & VM-034 \\
\hline 30 & Brancker & $\mathrm{T}-3305$ & T-3283 \\
\hline 35 & MVMS & 500501-UCSB & 200203-UCSB \\
\hline 40 & Brancker & $\mathrm{T}-3703$ & T-3309 \\
\hline 45 & VMCM & VM-033 & VM-003 \\
\hline 50 & Brancker & T-4489 & $\mathrm{T}-4492$ \\
\hline 55 & VMCM & VM-015 & VM-014 \\
\hline 60 & Brancker & $T-4487$ & T-3296 \\
\hline 65 & MVMS & 401405-LD & 500301-LD \\
\hline 72.5 & Brancker & T-4481 & T-3699 \\
\hline 80 & MVMS & 500601-UCSB & 200201-UCSB \\
\hline 90 & Brancker & $\mathrm{T}-3301$ & T-2535 \\
\hline 100 & Seacat & 357 & 927 \\
\hline 125 & Brancker & $T-4491$ & $\mathrm{~T}-2536$ \\
\hline 150 & Seacat & 994 & 144 \\
\hline 175 & Brancker & T-3761 & T-3308 \\
\hline 200 & Seacat & 992 & 929 \\
\hline 225 & Brancker & $\mathrm{T}-4493$ & T-3702 \\
\hline 250 & Seacat & 993 & 142 \\
\hline 300 & Brancker & T-2534 & $T-4495$ \\
\hline
\end{tabular}




\section{Appendix C: VMCM Record Format}

\section{RECORD COUNTER (TIME)}

The first 16 bits ( 4 characters) of data comprise the record number. The counter is incremented once each data record. The first record number is one and is used to initialize the instrument. The data and length of the first record may be invalid and should be ignored. Record two contains data for the first record interval. After 65535 records, the record counter will reset to zero and begin its normal counting.

\section{NORTH VECTOR}

Each vector is scaled from a 24 bit accumulator and stored in a 16 bit floating point representation. This vector is the algebraic sum of the NORTH component of current flow from each sample.

\section{EAST VECTOR}

Each vector is scaled from a 24 bit accumulator and stored in a 16 bit floating point representation. This vector is the algebraic sum of the EAST component of current flow from each sample.

\section{ROTOR 2 (X CURRENT FLOW) (UPPER)}

The rotor counts are an algebraic sum of the counts for a record interval. Rotor counts are scaled from a 24 bit accumulator and stored as a 16 bit floating number.

\section{ROTOR 1 (Y CURRENT FLOW) (LOWER)}

The rotor counts are an algebraic sum of the counts for a record interval. Rotor counts are scaled from a 24 bit accumulator and stored as a 16 bit floating number.

\section{COMPASS}

The compass field is an 8 bit, 2's complement number (-128 to 128 decimal). The stored value is measured at the beginning of the last sample of the record interval.

\section{TEMPERATURE}

One temperature sample is taken just before the end of the last record interval.

Record interval $=2$ seconds to 2 hours

Sample interval $=0.25$ seconds to 2 seconds in quarter second steps

\begin{tabular}{|c|c|c|c|c|c|c|c|c|}
\hline $\begin{array}{l}\text { PREAMBLE } \\
\text { (2) }\end{array}$ & $\begin{array}{c}\text { TIME } \\
\text { (4) }\end{array}$ & $\begin{array}{c}\text { NORTH } \\
\text { (4) }\end{array}$ & $\begin{array}{c}\text { EAST } \\
\text { (4) }\end{array}$ & $\begin{array}{l}\mathrm{R} 2 \\
\text { (4) }\end{array}$ & $\begin{array}{l}\mathrm{R} 1 \\
\text { (4) }\end{array}$ & $\underset{\text { (2) }}{\text { COMPASS }}$ & $\begin{array}{l}\text { TEMP } \\
\text { (4) }\end{array}$ & $\begin{array}{l}\text { PARITY } \\
\text { (1) }\end{array}$ \\
\hline
\end{tabular}




\begin{tabular}{|c|c|c|}
\hline $\begin{array}{l}\text { REPORT DOCUMENTATION } \\
\text { PAGE }\end{array}$ & 1. REPORT NO. WHOI-97-08 & 3. Recipient's Accession No. \\
\hline \multirow{2}{*}{\multicolumn{2}{|c|}{$\begin{array}{l}\text { 4. Title and Subtitle } \\
\text { Arabian Sea Mixed Layer Dynamics Experiment Data Report }\end{array}$}} & $\begin{array}{l}\text { 5. Report Date } \\
\text { July } 1997\end{array}$ \\
\hline & & 6. \\
\hline $\begin{array}{ll}\text { 7. Author(s) } & \text { Mark F. Baumg } \\
& \text { Robert A. Welle } \\
\end{array}$ & $\begin{array}{l}\text { tner, Nancy J. Brink, William M. Ostrom, Richard P. Trask, } \\
\text { Tommy D. Dickey and John Marra }\end{array}$ & $\begin{array}{l}\text { 8. Performing Organization Rept. No. } \\
\text { WHOI-97-08 }\end{array}$ \\
\hline \multicolumn{2}{|c|}{ 9. Performing Organization Name and Address } & 10. Project/Task/Work Unit No. \\
\hline \multicolumn{2}{|c|}{$\begin{array}{l}\text { Woods Hole Oceanographic Institution } \\
\text { Woods Hole, Massachusetts } 02543\end{array}$} & $\begin{array}{l}\text { 11. Contract(C) or Grant(G) No. } \\
\text { (C) N00014-94-1-0161 } \\
\text { (G) }\end{array}$ \\
\hline \multirow{2}{*}{\multicolumn{2}{|c|}{$\begin{array}{l}\text { 12. Sponsoring Organization Name and Address } \\
\text { Office of Naval Research }\end{array}$}} & $\begin{array}{l}\text { 13. Type of Report \& Period Covered } \\
\text { Technical Report }\end{array}$ \\
\hline & & 14. \\
\hline
\end{tabular}

15. Supplementary Notes

This report should be cited as: Woods Hole Oceanog. Inst. Tech. Rept., WHOI-97-08.

16. Abstract (Limit: 200 words)

The Arabian Sea is characterized by strong, large-scale atmospheric forcing during the summer (southwest) and winter (northeast) monsoons. To investigate air-sea interactions related to this unique surface forcing, a moored array was deployed from 15 October 1994 to 19 October 1995 just south of a region that experiences the climatological maximum winds during the summer monsoon. The array consisted of two Scripps Institution of Oceanography surface toroid buoys, two University of Washington subsurface moorings and a surface $3 \mathrm{~m}$ discus buoy deployed by the Woods Hole Oceanographic Institution (WHOI). The WHOI buoy carried redundant meteorological packages to measure wind speed and direction, air temperature, relative humidity, barometric pressure, incoming short- and long-wave radiation and precipitation. Oceanographic instrumentation was deployed on the WHOI buoy's bridle and mooring line to collect time series of temperature, salinity and velocity at various depths. Four multi-variable moored systems (MVMS) were also deployed along the mooring line by the Lamont-Doherty Earth Observatory and the University of California at Santa Barbara to record both bio-optical and physical parameters. This report describes the instrumentation deployed on the WHOI buoy and the processing and editing of the returned data. The data are then summarized in graphical and tabular formats.

17. Document Analysis a. Descriptors air-sea interaction

moored data

Arabian Sea

b. Identifiers/Open-Ended Terms

c. COSATI Field/Group

18. Availability Statement

Approved for public release; distribution unlimited.

\begin{tabular}{|l|l|}
\hline $\begin{array}{c}\text { 19. Security Class (This Report) } \\
\text { UNCLASSIFIED }\end{array}$ & $\begin{array}{c}\text { 21. No. of Pages } \\
169\end{array}$ \\
\hline 20. Security Class (This Page) & 22. Price \\
\hline
\end{tabular}




\section{DOCUMENT LIBRARY}

\section{Distribution List for Technical Report Exchange - February 1996}

University of California, San Diego

SIO Library $0175 \mathrm{C}$

9500 Gilman Drive

La Jolla, CA 92093-0175

Hancock Library of Biology \& Oceanography

Alan Hancock Laboratory

University of Southern California

University Park

Los Angeles, CA 90089-0371

Gifts \& Exchanges

Library

Bedford Institute of Oceanography

P.O. Box 1006

Dartmouth, NS, B2Y 4A2, CANADA

Commander

International Ice Patrol

1082 Shennecossett Road

Groton, CT 06340-6095

NOAA/EDIS Miami Library Center

4301 Rickenbacker Causeway

Miami, FL 33149

Research Library

U.S. Army Corps of Engineers

Waterways Experiment Station

3909 Halls Ferry Road

Vicksburg, MS 39180-6199

Institute of Geophysics

University of Hawaii

Library Room 252

2525 Correa Road

Honolulu, HI 96822

Marine Resources Information Center

Building E38-320

MIT

Cambridge, MA 02139

Library

Lamont-Doherty Geological Observatory

Columbia University

Palisades, NY z10964

Library

Serials Department

Oregon State University

Corvallis, OR ${ }^{\top} 97331$

Pell Marine Science Library

University of Rhode Island

Narragansett Bay Campus

Narragansett, RI 02882
Working Collection

Texas A\&M University

Dept. of Oceanography

College Station, TX 77843

Fisheries-Oceanography Library

151 Oceanography Teaching Bldg.

University of Washington

Seattle, WA 98195

Library

R.S.M.A.S.

University of Miami

4600 Rickenbacker Causeway

Miami, FL 33149

Maury Oceanographic Library

Naval Oceanographic Office

Building 1003 South

1002 Balch Blvd.

Stennis Space Center, MS, 39522-5001

Library

Institute of Ocean Sciences

P.O. Box 6000

Sidney, B.C. V8L 4B2

CANADA

National Oceanographic Library

Southampton Oceanography Centre

European Way

Southampton SO14 3ZH

UK

The Librarian

CSIRO Marine Laboratories

G.P.O. Box 1538

Hobart, Tasmania

AUSTRALIA 7001

Library

Proudman Oceanographic Laboratory

Bidston Observatory

Birkenhead

Merseyside L43 7 RA

UNITED KINGDOM

IFREMER

Centre de Brest

Service Documentation - Publications

BP 7029280 PLOUZANE

FRANCE 